
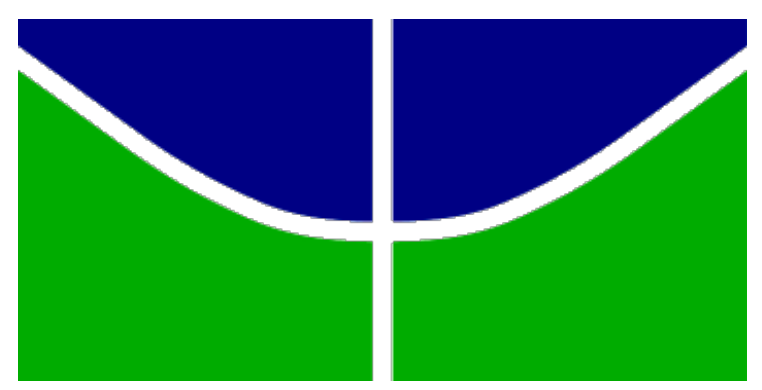

UNIVERSIDADE DE BRASÍLIA

INSTITUTO DE LETRAS

DEPARTAMENTO DE LINGUÍSTICA, PORTUGUÊS E LÍNGUAS CLÁSSICAS PROGRAMA DE PÓS-GRADUAÇÃO EM LINGUÍSTICA

IMIGRAÇÃO BOLIVIANA EM MARES PAULISTANOS DANTES NAVEGADOS: INCLUSÃO DOS (IN)VISÍVEIS E (DES)CONSTRUÇÃO IDENTITÁRIA

Rubens Lacerda de Sá

Brasília

2015 
Dissertação apresentada à banca examinadora do Programa de Pós-Graduação em Linguística da Universidade de Brasília como requisito parcial para obtenção do título de Mestre em Linguística.

Prof. Dr. Kleber Aparecido da Silva Orientador 


\section{REFERÊNCIA BIBLIOGRÁFICA}

SÁ, Rubens Lacerda de. Imigração Boliviana em Mares Paulistanos Dantes Navegados:

Inclusão dos (In)visíveis e (Des)construção Identitária. 186 f. Dissertação (Mestrado). Brasília: Universidade de Brasília, 2015.

\section{FICHA CATALOGRÁFICA}

Imigração Boliviana em Mares Paulistanos Dantes Navegados: Inclusão dos (In)visíveis e (Des)construção Identitária / Rubens Lacerda de Sá. - Brasília: Universidade de Brasília, 2015.

Inclui bibliografia

1. Imigrantes bolivianos. 2. Inclusão social. 3. Identidade(s). 4. Língua(gem). I. Sá, Rubens Lacerda de. II. Orientação: Prof. Dr. Kleber Aparecido da Silva.

Direitos reservados à

\section{Rubens Lacerda de Sá}

E-mail: rubens.ladesa@gmail.com | Telefone: + 5511 98751-1334 • + +5535 3409-1334

Esta dissertação de mestrado não pode ser reproduzida, transmitida ou copiada no todo ou em partes, por meio mecânico ou digital, sem a devida autorização, preferencialmente por escrito, do autor embora citações sejam estimuladas, desde que a fonte seja devidamente citada. 


\title{
IMIGRAÇÃO BOLIVIANA EM MARES PAULISTANOS DANTES NAVEGADOS: INCLUSÃO DOS (IN)VISÍVEIS E (DES)CONSTRUÇÃO IDENTITÁRIA
}

\author{
Rubens Lacerda de Sá
}

BANCA EXAMINADORA

Professor Doutor Kleber Aparecido da Silva (UnB)

Professor Doutor Kanavillil Rajagopalan (UNICAMP)

Professora Doutora Francisca Cordélia Oliveira da Silva (UnB)

Professora Doutora Ester Maria de Figueiredo Souza (UESB) 


\section{AGRADECIMENTOS}

"O que faz andar o barco não é a vela enfunada, mas o vento que não se vê"

"Sou um barco à vela na imensidão do mar [da humanidade]"

— Rubens Lacerda de Sá

Em ininterrupta jornada, como embarcação que sou, de que outra forma poderia iniciar esta seção de agradecimentos, senão valendo-me das palavras de Platão? A quem mais, senão ao Almirante-Mor deste navio que sou, posso atribuir a função de vento impelente que, por um presente materno, tem movido minha vida até aqui e a quem me esforço em agradar para que siga impelindo-me por toda a eternidade sem importar o destino que me galadeie? A Este atribuo as merecidas e inspiradas palavras registradas nas Santas Escrituras, a Bíblia:

"Digno és Jeová, sim [meu] Deus, de receber a glória, e a honra, e o poder, porque criaste todas as coisas e porque elas existiram e foram criadas por tua vontade"

- Revelação (Gr.: Apokálypsis) 4:11.

Num segundo momento, devo as minhas mais sinceras e profundas expressões de gratidão, amor eterno e carinho à comissária, deste navio que sou, minha amada esposa Elaine, pela gestão de meus assuntos, pela administração de minha vida, pois embora escondida numa das cabinas, desempenha o papel da mais extrema relevância para eu poder continuar navegando por este bravio mar com esta embarcação surrada.

Como não incluir aqui a praticante desta embarcação, minha cão-beleza, Duda, pelo irracional (ou seria próximo ao racional em alguns momentos?) suporte e alegria nos momentos de dor física, emocional e angústia? Pelos inúmeros e constantes momentos em meu colo, ou deitada em minha mesa, enquanto eu estudava, lia ou escrevia e quando de repente, como que prevendo, dizia-me com seu olhar e latido peculiar: "para um pouco, você já está bastante cansado. Vamos relaxar, oxigenar a mente, brincar lá fora; vamos correr!”. 
Não poderia deixar de estar presentes neste texto os mestres que mantêm esta embarcação na rota, minha família, desde a figura de meus pais, Manoel e Inácia, meus irmãos e irmãs, Mônica, Flávia, Jonatas e, o gordito mais gente boa que conheço, meu irmão Giovani. Incluo aqui também todos os demais familiares, no grupo do whatsapp, que a cada dia, reiteram o sentido da palavra família. Há ainda o Getúlio pelo imenso apoio tecnológico. Ainda neste grupo de mestres, amplio minha família para o âmbito espiritual, no qual incluo todos os meus oito milhões de irmãos e irmãs na fé que, quais Testemunhas de Jeová que somos, continuamos navegando juntos, impávidos, pelas águas agitadas desse mar. Neste grupo, destaco com especial carinho Denise Leyton pela gentil cessão do sonho de pesquisa, Andrew Botelho, Uirá Limeira e Zenaide Santos pelo apoio logístico e hospitalidade.

Falarei agora do meu oficial de náutica, que assumiu a direção desta nau com muita destreza, respeito, flexibilidade e especial vínculo de amizade, meu orientador, o Prof. Dr. Kleber Aparecido da Silva, que como meu irmão na fé, simplesmente Klebão. Sem seu acolhimento, generosidade e aposta nessa embarcação, já surrada pelas ondas e tempestades da vida, não teria sido possível navegar por mais essa rota - a acadêmica, com tanta leveza e amenidade. Sua postura e atitude para comigo lembram-me um grande poeta, a quem replico:

"E à cansada velhice é bem fagueiro Esses restos da vida disfrutar"

- Gonçalves Dias

Hei ainda de mencionar em meus agradecimentos os azeitadores deste navio, que com destreza lubrificam e oxigenam as máquinas para que este possa continuar quebrando as ondas nesta nova e, por vezes raivosa e árdua, rota - a acadêmica. Alisto aqui os colegas da academia, e seus debates, seminários, leituras, etc., mas com especial menção ao integrantes do 'grupo cidadão', Keila, Juscelino e Helenice, que de repente embarcaram e disseram: "vamos navegar contigo!”. Que presente! Não poderia esquecer de citar as queridas Elke Martins, pelas trocas e elogios motivadores, Sônia Guedes, irmã na fé, pelas conversas sempre animadas e inúmeras caronas, e Isa Gurgel, pelo tom maternal e olhar fotográfico.

Por fim, cito todos os grumetes, que direta ou indiretamente, deram sua contribuição.

A todos, muitíssimo obrigado! 
"Pus o meu sonho num navio e o navio em cima do mar; - depois, abri o mar com as mãos, para o meu sonho [não] naufragar, [mas, antes, navegar ...]" 


\section{RESUMO}

Parto do pressuposto comum de que todos os imigrantes devem receber um trato social verdadeiramente inclusivo e igualitário balizado nos direitos de universalidade e individualidade, e despojado de paradigmas excludentes aonde quer que imigrem. A sociedade brasileira, e ressalto neste texto a paulistana, é culturalmente híbrida, plurilíngue e oblíqua (CANCLINI, 2007). Aqui designo-a como mares ao referir-me ao tecido social da cidade que tem sido navegada por incontáveis imigrantes das mais remotas partes do planeta. Tal fluxo de imigrantes resulta em complexidade de acomodação (BAENINGER, 2012), ocasionando aos imigrantes que possuem razoável poder aquisitivo ou conhecimentos técnicos especializados a reserva invariável de espaços sociais inclusivos, ao passo que os em desvantagem social são apenas integrados a um sistema que os deixa à mercê de toda uma estrutura social segregacionista (HORKHEIMER; ADORNO, 1985; GUEBERT, 2012). São feitos invisíveis socialmente, embora não o sejam, de fato, no cotidiano da cidade; são apenas alocados numa lógica binária de normalidade e anormalidade. Entendo que tal evento afeta de forma nevrálgica a identidade de tais imigrantes, envolvidos nessa diáspora internacional (SILVA, 2014; HALL, 2008), pois são confrontados com a composição de uma nova identidade de espectro binacional sofrendo com esta construção que se dá em detrimento de sua identidade primeira visto que almejam ser aceitos socialmente. (RAJAGOPALAN, 2003; SILVA, 2008). Diante desse cenário, meu foco principal nesta pesquisa reside nos imigrantes bolivianos residentes no bairro Bom Retiro na capital paulista. Objetivo identificar na análise desta pesquisa de cunho etnográfico balizada nos princípios dos estudos linguísticos críticos e transgressores (PENNYCOOK, 2008), levada à termo em um grupo focal por meio de vídeos, fotos e histórias de vida contadas por meio de narrativas escritas e visuais. Pretendo verificar como tais imigrantes são afetados individual e coletivamente por esse tsunami social a partir do enfeixamento dos objetos de estudo: inclusão e identidade. Por fim, dadas as constatações daí advinhas, proponho estudos mais aprofundados sobre essa temática desde uma ótica mais específica e de cunho social.

Palavras-chave: Imigrantes bolivianos. Inclusão social. Identidade(s). Língua(gem). 


\begin{abstract}
It's my personal belief that all immigrants should be granted a truly equal and inclusive social reception based upon the universal rights of equality with no excluding paradigms wherever they journey to. The Brazilian, specially the paulistana, society is well-known for its cultural hybridism, obliquity and plurilingual organisation (CANCLINI, 2007). I hereby ascribe it as seas when referring to the city's social network always sailed by countless immigrants from all over the world. Such influx has resulted in a huge accommodation complexity (BAENINGER, 2012) whose aftereffect is that those immigrants possessing either outstanding financial resources or specialised and technical knowledge have inclusive social spaces guaranteed in the local society whereas those monetarily impaired are barely integrated and left to the mercy of a notably segregationist social structure (HORKHEIMER; ADORNO, 1985; GUEBERT, 2012). These socially invisibilised, though visible in the daily life of the city itself, are only placed upon a binary logic of normality and abnormality. In order to be socially accepted, my grasping is that such an occurrence neuralgically affects the identity of these immigrants who are part of these international diaspora (SILVA, 2014; HALL, 2008) since they ought to face the construction of a new identity which has got a binational composition thereupon built up to the detriment of his own first identity. (RAJAGOPALAN, 2003; SILVA, 2008). Given such a scenario, my main research focus lies on the Bolivian immigrants dwelling in Bom Retiro neighbourhood of the capital city of São Paulo. Based upon an ethnographical-like research, grounded on the principles of critical and transgressive linguistic studies (PENNYCOOK, 2008), it is carried out through a focal group by means of videos, photographs and life histories narrated both visually and in written which can help me bundle the constructs inclusion and identity. I, therefore, aim at identifying how much affected are those Bolivian immigrants both individually and collectively by such a social tsunami. Eventually, I shall propose further and deeper studies over this subject from a more specific, acute and social perspective.
\end{abstract}

Keywords: Bolivian immigrants. Social inclusion. Identity(ies). Language(s). 


\section{ÍNDICE GERAL}

\section{LISTA DE TABELAS}

Tabela 1 Principais marcos legais e seus objetivos 16

Tabela 2 Tipos de visto exigidos para entrada e estadia no Brasil 20

Tabela $3 \quad$ Os participantes da pesquisa $\quad 81$

Tabela 4 Organização das atividades no grupo focal 86

Tabela 5 Etapas da contação das histórias de vida 90

Tabela $6 \quad$ Modos de operacionalização ideológica 100

\section{LISTA DE FIGURAS}

Figura 1 Ideologias veladas 29

Figura 2 Inclusão hoc opus, hic labor est 40

Figura 3 (Des)construção identitária 56

$\begin{array}{lll}\text { Figura } 4 & \text { Fotos representativas da Bolívia } & 102\end{array}$

$\begin{array}{lll}\text { Figura } 5 & \text { Foto do videoclipe } & 111\end{array}$

$\begin{array}{lll}\text { Figura } 6 & \text { Narrativa visual: Mariana }\end{array}$

$\begin{array}{lll}\text { Figura } 7 & \text { Narrativa visual: Juan } & 114\end{array}$

$\begin{array}{lll}\text { Figura } 8 & \text { Narrativa visual: Pedro } & 115\end{array}$

$\begin{array}{lll}\text { Figura } 9 & \text { Narrativa visual: Carolina } & 117\end{array}$

$\begin{array}{lll}\text { Figura } 10 \quad \text { Narrativa visual: José } & 119\end{array}$

$\begin{array}{lll}\text { Figura } 11 \quad \text { Antissociedade } & 128\end{array}$

$\begin{array}{lll}\text { Figura } 12 & \text { Sistema da Avaliatividade } & 131\end{array}$

Figura 13 Categoria do Subsistema de Atitude 133

\section{LISTA DE GRÁFICOS}




\section{LISTA DE FOTOS}

Foto 1 Velas ao vento esvoaçante 3

Foto $2 \quad$ Movimente a bússola e o mapa! 11

$\begin{array}{lll}\text { Foto } 3 & \text { E se desprende a âncora } & 28\end{array}$

Foto 4 Por fim, navega o veleiro e seus mastros 76

Foto $5 \quad$ Atraca-te, pois! 93

Foto $6 \quad$ Dista no horizonte! 136

Foto $7 \quad$ É chegado o desenredo 149

\section{LISTA DE QUADROS}

Quadro $1 \quad$ Condensando as ideias iniciais 10

$\begin{array}{lll}\text { Quadro } 2 & \text { Sintetizando o panorama } & 27\end{array}$

Quadro 3 Compendiando as ideologias emersas 39

Quadro 4 Coligindo a inclusão (des)mascarada 55

$\begin{array}{lll}\text { Quadro 5 Epilogando as identidades em movimento } & 74\end{array}$

$\begin{array}{lll}\text { Quadro 6 } & \text { Os caminhos que seguirei na pesquisa } & 92\end{array}$

Quadro $7 \quad$ As análises linguísticas $\quad 97$

Quadro 8 Música: El emigrante 122

\section{LISTA DE APÊNDICES}

Apêndice A $\quad$ Fragmentos de atividade no grupo focal 166

$\begin{array}{lll}\text { Apêndice B } & \text { Fragmento de nota de campo } & 167\end{array}$

$\begin{array}{lll}\text { Apêndice C } & \text { Fragmentos de narrativas escritas } & 168\end{array}$

$\begin{array}{lll}\text { Apêndice D } & \text { Exemplos de narrativas visuais } & 169\end{array}$

$\begin{array}{lll}\text { Apêndice E } & \text { Fotos e fonte dos videoclipes usados pelo autor } & 170\end{array}$

Apêndice F $\quad$ Imagens da Bolívia 171 


\section{LISTA DE EXCERTOS}

Excerto 1 Legitimação por universalização: Juan 103

Excerto 2 Legitimação por narrativização: Juan 103

$\begin{array}{lll}\text { Excerto } 3 \text { Legitimação por narrativização: Carolina } & 104\end{array}$

Excerto 4 Legitimação por narrativização: José 104

$\begin{array}{lll}\text { Excerto } 5 & \text { Legitimação por narrativização: Pedro } & 104\end{array}$

$\begin{array}{lll}\text { Excerto } 6 & \text { Legitimação por narrativização: Mariana } & 104\end{array}$

Excerto 7 Legitimação por racionalização: Carolina 106

Excerto 8 Dissimulação por deslocamento: Carolina 107

$\begin{array}{lll}\text { Excerto } 9 & \text { Dissimulação por eufemização: Mariana } & 108\end{array}$

Excerto 10 Dissimulação por eufemização: Juan 109

Excerto 11 Dissimulação por eufemização: Carolina 109

Excerto 12 Dissimulação por eufemização: Pedro 109

$\begin{array}{lll}\text { Excerto } 13 \text { Unificação por padronização: Mariana } & 112\end{array}$

Excerto 14 Fragmentação por expurgo: Juan 113

$\begin{array}{lll}\text { Excerto } 15 & \text { Fragmentação pela diferença: Pedro } & 115\end{array}$

Excerto 16 Reificação pela naturalização: Carolina 116

Excerto 17 Reificação pela naturalização: José 118

$\begin{array}{lll}\text { Excerto } 18 & \text { Comentário sobre o videoclipe: Pedro } & 127\end{array}$

$\begin{array}{lll}\text { Excerto } 19 \text { Comentário sobre o videoclipe: Mariana } & 128\end{array}$

Excerto 20 Comentário sobre o videoclipe: José 130

$\begin{array}{lll}\text { Excerto } 21 & \text { Comentário sobre o videoclipe: Carolina } & 132\end{array}$

Excerto 22 Comentário sobre o videoclipe: Juan 134 


\section{SUMÁRIO}

Preâmbulo

Introdução - O começo da jornada: subindo a bordo e içando as velas

i. "No princípio Deus criou os céus e a terra" (Gênesis 1:1)

$\begin{array}{ll}\text { ii. Objetivo e perguntas de pesquisa } & 7\end{array}$

iii. A organização da dissertação $\quad 8$

Capítulo 1 - Contextualização: calibrando a bússola e mapeando a rota

1.1. Migrações (inter)nacionais: panorama histórico do além-mar

1.2. Marcos legais: o preamar do imigrante?

1.3. Imigração boliviana: espraiando-se em São Paulo

1.4. Imigração boliviana: o deflúvio familiar, religioso

1.5. Imigração boliviana: fluxo e refluxo comunitário

2.1. Demergeretur doctrinis seiuncta

2.1.1. Estado e controle social

2.1.2. Poder invisível e reprodutor

2.1.3. Nova ordem econômica

2.2. Inclusão dos (in)visíveis

2.2.1. Marco histórico

2.2.2. Mote filosófico

2.2.3. Axioma sociológico

2.3. Identidades em (des)construção

2.3.1. Língua e linguagem

2.3.2. Políticas linguísticas 
3.1. O desenho da pesquisa $\quad 76$

3.2. O lócus investigado $\quad 79$

3.3. Os navegantes $\quad 79$

3.4. Os procedimentos de coleta $\quad 82$

3.4.1. Atividades no grupo focal 84

3.4.1.1. Notas de campo $\quad 87$

3.4.1.2. Histórias de vida: narrativas escrita e visual $\quad 88$

3.4.2. Áudio, vídeo e imagens: à guisa de esclarecimento 91

Capítulo 4 - A análise dos dados: primeira atracagem em um cais

4.1. Análise de Discurso Crítica: ideologias imersas e inclusão dos (in)visíveis 98

4.2. A Teoria da Avaliatividade e o desvelar de identidades (des)construídas $\quad 120$

Capítulo 5 - Constatações: “Terra à vista!” 136

5.1. À guisa de (in)conclusões $\quad 136$

5.2. Proposições 139

5.2.1. (Nova) Pragmática em contextos de imigração 141

5.2.2. Realismo Crítico: emancipação e transformação do imigrante 145

Remate - O desfecho da jornada: hora do desembarque no porto

Referências

Apêndices 



\section{PREÂMBULO}

De forma bastante sucinta, gostaria de apresentar ao leitor o cenário em que esta pesquisa está circunscrita. Trata-se de um bairro localizado na região centro-sul da cidade São Paulo, chamado Bom Retiro. Por ser um polo de moda e de confecções, atrai muito a atenção dos imigrantes bolivianos que, ao chegar de seu país, não veem outra alternativa de trabalho senão se embrenhar neste setor laboral, que é um dos poucos a que têm acesso.

Desembarcam em sua maioria nesse bairro sob o convite, as instâncias e, na grande maioria das vezes, sob o patrocínio financeiro de parentes, amigos ou simplesmente de compatriotas que já desfrutam de certa estabilidade no setor de trabalho mencionado anteriormente. Os recém-chegados têm, diante de si, uns bons anos de trabalho até que possam adquirir certa independência financeira, pois precisam saldar suas dívidas com seus patrocinadores, aportar recursos aos familiares deixados em sua localidade de origem, bem como custear gastos com suas estadias. Sendo assim, diante de tais circunstâncias, não thes restam outra alternativa senão se submeterem a jornadas laborais exaustivas, atém de uma vida em condições precárias com pouco saneamento, com o mínimo de conforto, e uma alimentação inadequada, o que, consequentemente ocasiona à deterioração da saúde.

Acrescido a todos os percalços de ordem interna, há, ainda, as dificuldades de adaptação na comunidade local, composta de brasileiros e coreanos. Os últimos, embora igualmente imigrados, desfrutam de melhores condições de vida, dada sua saúde financeira. Já os imigrantes bolivianos passam a enfrentar problemas com a língua, por apresentarem um certo grau de dificuldade para entender o Português. Em acréscimo, sofrem discriminação por virem de um país economicamente mais pobre e, em decorrência disso, são estereotipados como sendo pessoas sujas, incultas e não sociáveis. Todo o cenário, a que faço menção, gera problemas bastante sérios com a construção da identidade desse povo, que agora passa a ser binacional, Brasil-Bolívia, e que, muitas vezes, força-os a rejeitar sua identidade primeira ou nativa. São igualmente excluídos da sociedade, ou pelo menos invisibilizados e neutralizados por conta dos muitos estereótipos a eles atribuídos.

É neste cenário mais amplo, onde convivo diariamente com tais bolivianos e estou pessoal e particularmente inserido, que minha pesquisa será consubstanciada visando a compreender mais profundamente todas essas questões com vistas a propor ações que possam, senão resolver, pelo menos atenuar ou minimizar o sofrimento desses imigrantes. 


\section{INTRODUÇÃO}

\section{O começo da jornada: subindo a bordo e içando as velas}

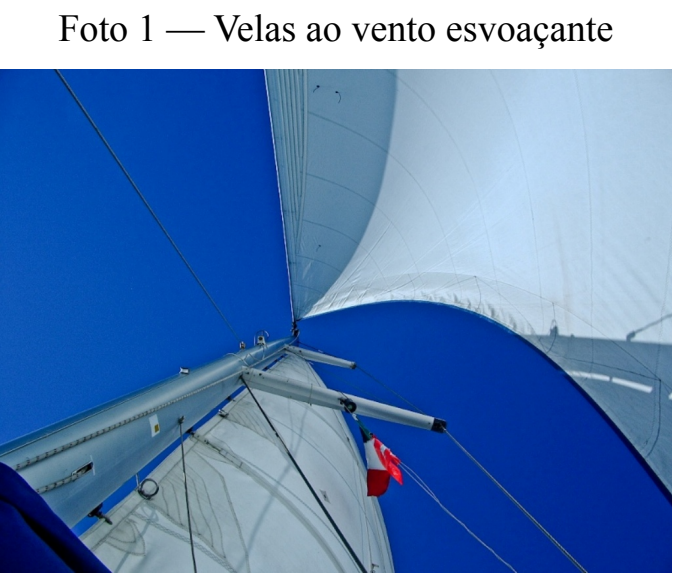

"Não existe vento favorável para o marinheiro que não sabe aonde ir."

- Sêneca

Fonte: Google ${ }^{2}$

i. "No princípio Deus criou os céus e a terra" (Gênesis 1:1)

Convido o leitor do meu texto a subir a bordo desta embarcação e iniciarmos nossa jornada com as bastante emblemáticas palavras registradas no texto bíblico, pois as uso para destacar a origem deste trabalho, desta navegação. Aludo às palavras de Sêneca devido ao fato de eu pertencer a uma comunidade religiosa, as Testemunhas de Jeová, acrescido de minhas vivências pessoais como nacional e como imigrante. Em decorrência de minhas andanças pelo Brasil e pelo exterior, tive o privilégio de entrar em contato com as realidades espelhadas nos construtos que balizam este texto, o que contribuiu substancialmente para que eu estabelecesse um norte a este trabalho de pesquisa.

A escolha do texto bíblico em tela para esta seção é proposital, pois gostaria de demonstrar que, no meu entendimento e partindo de uma óptica cristã, ninguém melhor do que o Criador do ser humano, Jeová Deus, para estabelecer o modelo no que tange à inclusão e manutenção identitária de imigrantes em terras estrangeiras. A história bíblica atesta que já desde os primórdios esse texto sagrado aborda e regula a questão de imigração.

\footnotetext{
2 Disponível: http://www.gaytravelherald.com/pt/puerto-vallarta-mexico-gay-guide. Acessado em 20/04/2015.
} 
Portanto, como ponto de partida, farei um breve apanhado a respeito. Inicio por mencionar que a primeira proposta de imigração humana foi emitida por Jeová uns 350 anos após o dilúvio, quando orientou ao patriarca Abraão que se mudasse de sua terra de origem, com todos os seus pertences e familiares, para outro país (Gênesis 12:1-3). Vale notar que não se tratava de uma imigração em busca de melhores condições de vida porque a terra natal de Abraão era uma cidade bastante próspera. O objetivo principal se relacionava com a construção de uma futura identidade nacional e de uma sociedade totalmente inclusiva, baseada em padrões que seriam gradativamente estabelecidos pelo próprio Jeová Deus.

Passados uns 286 anos e após uma série de acontecimentos de ordem social e familiar, os israelitas, como eram chamados os que compunham essa nação divinamente nomeada, viviam como estrangeiros no Egito. Num primeiro momento, a história mostra que o povo egípcio acolheu os israelitas por razões de interesse comum (Gênesis 45:16-20). No entanto, durante aproximadamente quatro séculos e com a mudança das lideranças governamentais no país, a nação egípcia passou de acolhedora para tiranicamente opressora, de inclusiva para excludente. Diante dessa nova realidade, Jeová designa a Moisés para liderar a emigração do povo israelita, libertando-os do jugo egípcio, e estabelecendo-os numa região com fronteiras nacionais próprias que possibilitassem um passo adiante em direção à construção de uma sociedade notadamente inclusiva e com uma identidade nacional própria (Êxodo 12:40-42). Vale ressaltar neste ponto que Jeová aproveita essa ocasião para educar o seu povo na perspectiva inclusiva, na preservação e no respeito à identidade do outro, pois muitos egípcios, anteriores opressores, agora passariam a fazer parte da migrante nação e, como tais, deveriam ser aceitos e incluídos em sua nova sociedade (Êxodo 12:38; Números 11:4).

Avançando no relato bíblico, agora por volta do ano 1.450 a.E.C., os israelitas já estão estabelecidos em seu território nacional e com fronteiras bem definidas. Nesse ponto da história, o povo já tem, como marca distintiva, o acolhimento a imigrantes em seu meio, os quais eram chamados de residentes forasteiros. A enciclopédia bíblica Estudo Perspicaz das Escrituras, volume 3, ao definir a acepção desse termo declara, parcialmente, na página 425: 
No seu significado geral, o substantivo hebraico ger se refere a qualquer pessoa que esteja residindo como forasteiro, fora de sua terra natal, e cujos direitos civis são restritos. Pode ter ou não ligações religiosas com os naturais do país em que reside. [...] Quando a Bíblia se refere a uma pessoa de origem não israelita em relação à comunidade israelita, a designação "residente forasteiro" se aplica às vezes a uma pessoa que se tornou prosélito ou adorador pleno de Jeová. Às vezes se refere a um colono na terra da Palestina, que estava disposto a viver entre os israelitas, obedecendo às leis fundamentais do país, mas que não aceitava plenamente a adoração de Jeová. O contexto determina a que classe se aplica o termo.

Partindo desse conceito, Jeová estabelece, em alguns artigos no texto da constituição da nação, o que esperava do israelita natural no que diz respeito ao trato equitativo e justo ao estrangeiro, ou residente forasteiro, que optasse viver no seio da nação (Levítico 19:33,34).

Ao abordar o tema da legislação, a mesma obra diz o seguinte na página 426:

Quando o pacto da Lei [ou carta magna] foi transmitido no monte Sinai, incorporou-se nele uma legislação especial, num espírito mui amoroso, que governava o relacionamento entre o residente forasteiro e o israelita natural. Por estar o residente forasteiro em desvantagem por não ser israelita de nascença, o pacto da Lei o favorecia com consideração e proteção especiais, pois continha muitos dispositivos a favor dos fracos e vulneráveis. Com regularidade, Jeová trazia à atenção dos de Israel que eles próprios conheciam as aflições enfrentadas por um residente forasteiro numa terra que não fosse dele, e, por isso, deviam demonstrar para com os residentes forasteiros entre eles o espírito generoso e protetor que não haviam usufruído. (Êxodo 22:21; 23:9; Deuteronômio 10:18) Basicamente, o residente forasteiro, especialmente o prosélito, devia ser tratado como irmão.

Outro fato relevante para o qual chamo a atenção é que Jeová, qual legislador, assentou na carta Magna que os israelitas naturais sofreriam sanções legais caso não aderissem ao texto constitucional que regia o trato aos imigrantes permanentes e temporários. (Deuteronômio 23:7). Nesse viés a obra supramencionada continua na página 426:

Judicialmente, garantia-se justiça imparcial ao residente forasteiro nos julgamentos que envolvessem um israelita natural. (Deuteronômio 1:16,17) Não se devia defraudá-lo, nem submetê-lo a um julgamento pervertido. (Deuteronômio 24:14,17) Lançavam-se maldições sobre aqueles que praticassem injustiça para com os residentes forasteiros. (Deuteronômio 27:19) As cidades de refúgio para o homicida desintencional estavam disponíveis para o residente forasteiro e para o colono, bem como para o israelita natural. — Números 35:15; Josué 20:9.

Transcorridos outros quinze séculos e após muitos eventos que marcaram a história do povo israelita, aponto o período em que Jesus, o líder do cristianismo, esteve na Terra. 
Refletindo o modelo estabelecido pelo próprio Jeová no que diz respeito à inclusão social de estrangeiros e à manutenção de sua identidade individual e coletiva, Jesus expõe os desvios morais da nação neste sentido e, no ano 36 Era Comum, são abertas, por assim dizer, as fronteiras nacionais que geravam exclusão de estrangeiros (Atos capítulo $10{ }^{3}$ ). Essa narrativa serve para ressaltar que Jeová não mudou seu conceito em relação aos imigrantes (Malaquias 3:6). Tal posicionamento divino é mais uma vez reforçado em profecias bíblicas proferidas no ano 98 Era Comum, pelo encarcerado apóstolo João, na ilha de Patmos, Grécia. (Revelação 7:9; 21:3,4).

Chegando aos nossos dias, destaco que o mesmo princípio orientador estabelecido por Jeová em toda a narrativa bíblica também é seguido pelas Testemunhas de Jeová. Conforme demostrado por inúmeros meios noticiosos, sua principal característica como ministros religiosos é a eliminação de fronteiras nacionais em seu meio, objetivando a manutenção de sua identidade religiosa e a inclusão social de todos os seus membros sem haver distinção de raça, cor, nação ou etnia 4 .

Pelo histórico resenhado acima e retomando à citação de Sêneca, reafirmo a origem de meu interesse no tema objeto desta pesquisa. Entendo que se trata de uma pauta bastante relevante dada a realidade social que vivemos mundialmente e o trato dispensado aos imigrantes de diversos países em sociedades que se esperaria serem acolhedoras e inclusivas.

\footnotetext{
${ }^{3}$ Para uma consideração mais detalhada desse capítulo e narrativa bíblica recomendo a obra 'Dê Testemunho Cabal' sobre o Reino de Deus publicado pela WATCHTOWER BIBLE and TRACT SOCIETY of NEW YORK, INC. Brooklyn, Nova Iorque, E.U.A. e ASSOCIAÇÃO TORRE de VIGIA de BÍBLIAS e TRATADOS, São Paulo, SP, Brasil, 2009.

${ }^{4}$ Para uma consideração sobre a imparcialidade, o amor fraternal e a união internacional como uma das marcas distintiva das Testemunhas de Jeová em todo o globo, recomendo a leitura dos capítulos 17, páginas 254-282; capítulos 19 e 20 páginas 304-339; e, capítulo 32 páginas 710-712 do livro Testemunhas de Jeová - Proclamadores do Reino de Deus, publicado pela WATCHTOWER BIBLE and TRACT SOCIETY of NEW YORK, INC. Brooklyn, Nova Iorque, E.U.A. e ASSOCIAÇÃO TORRE de VIGIA de BÍBLIAS e TRATADOS, São Paulo, SP, Brasil, 1993.
} 
ii. Objetivo e perguntas de pesquisa

Por muitas décadas, a cidade de São Paulo tem sido navegada por imigrantes das mais diversas nacionalidades e cada um dos grupos de imigrantes que por aqui passam, ou que aqui se estabelecem, deixam suas impressões digitais, suas marcas, na sociedade paulistana. Evidentemente não se trata de um processo que se consolida, se acomoda em pouco tempo, talvez sejam necessários anos para que essas impressões ou marcas sejam visíveis e até incorporadas na cultura da metrópole. O exemplo dos imigrantes portugueses, italianos e japoneses ilustra o acima mencionado.

Ademais, diante do espectral formato econômico mundial delineado nas últimas décadas, essa cidade passou a conviver com eventos imigratórios internacionais que impactam sobremaneira as mais diversas esferas da sociedade. Assim, nesta pesquisa busco entender esses eventos desde um ponto de vista linguístico e sociológico e trazer elementos teóricos para enfeixar o diálogo entre os construtos identidade e inclusão social dos imigrantes bolivianos, que desembarcam na capital paulista com bastante frequência, quase diariamente e sempre em grande quantidade.

Apresento um entendimento mais acurado das características e implicações desses eventos de imigração, o mapeamento de dados legais e históricos, e uma aproximação aos atores envolvidos nesse processo que concebo serem importantes para compreender a questão da (in)visibilidade de tais imigrantes numa perspectiva de inclusão social e, ainda, como suas identidades são (des)construídas nesse novo contexto em que se inserem, bem como que (trans)formação e impacto social relevante são (des)velados.

A inquietação-mestre ${ }^{5}$ que norteia e inspira toda esta pesquisa se relaciona aos eventos e processos sociais e linguísticos que são trazidos à baila no bojo das questões identitárias e de inclusão na sociedade local. Tal inquietação é a mola propulsora que se desdobra em cinco perguntas que almejam o entendimento da complexidade do tema em tela:

\footnotetext{
${ }^{5}$ Abordarei e revisitarei essa inquietação-mestre e as perguntas daí advindas à medida que navegamos, o leitor e eu, por esta pesquisa. Espero, assim, contribuir para uma melhor amarra aos elos deste texto.
} 
1. Que barreiras e impactos legais, históricos e institucionais advêm desse trâmite imigratório aos atores implicados nesse processo?

2. Assumindo que há desníveis e disparidades marcadamente ideológicos, excludentes e discriminatórios, no trato com os imigrantes bolivianos, que atitudes são reveladas por suas escolhas linguísticas ao falar da questão da inclusão e (in)visibilidade?

3. Como as histórias de vida, dos assim (in)visibilizados imigrantes bolivianos em tela, revelam a profundidade das questões de inclusão em âmbito local?

4. Que imagens representativas de seu país de origem são mantidas e que outras se manifestam e se transmutam à construção da [nova] identidade coletiva e (bi)nacional?

5. Como é (des)construída sua identidade a partir da decisão de sair de sua terra natal?

Como um leme que bem manobrado possibilita ao navio chegar ao seu destino, as perguntas acima permeiam toda a pesquisa e contribuem para que se retrate a problemática da imigração dos bolivianos na cidade de São Paulo sob o viés das questões e dos processos identitários entre dois países-polo e o almejo de inclusão social, considerando-se a ideia de equidade fundamentada na concepção dos direitos humanos e no desmantelamento da ciranda de exclusão na sociedade moderna.

iii. A organização da dissertação

Estar a bordo de um navio e preparando-me para içar as velas e fazer-me ao mar envolve organização para que a jornada seja prazenteira e profícua. Assim, discorro agora sobre a maneira como está arquitetada esta dissertação. Tomara que a desfrute, leitor amigo.

Para uma viagem segura, os comissários e oficiais náuticos da embarcação precisam, antes de mais nada, calibrar os equipamentos de navegação, em especial a bússola que os situará na imensidão do oceano, bem como mapear a rota que desejam seguir em segurança. Pretendo considerar cada uma de minhas perguntas de pesquisa nos capítulos um a três por um viés teórico e, por fim, no capítulo quatro, o capítulo das análises, demonstrar a razão de minhas asserções nos capítulos precedentes. 
Com este conceito em mente, e ensejando abordar minha primeira pergunta de pesquisa, no primeiro capítulo, procuro contextualizar o leitor sobre o movimento de imigrantes bolivianos na cidade de São Paulo que, como um mar, tem sido navegado há décadas. Para tanto, traço um panorama a partir de uma perspectiva histórica, jurídica e das instituições que acolhem tais imigrantes na capital paulista.

Os pressupostos teóricos apresentados no segundo capítulo, objetivam ancorar esse navio-texto nas teorias sociais elencadas e, com elas, abordar a temática das ideologias que subjazem práticas sociais que acabam por causar danos aos atores que são quase forçosamente assujeitados para serem minimamente inclusos socialmente e com consequências lamentáveis no que tange à sua identidade. Procuro apresentar o assunto de maneira crítica, como sugere a epígrafe de Leonardo da Vinci.

Já em alto-mar, epigrafo este terceiro capítulo com a antológica frase: "Navegar é preciso", inicialmente proferida pelo general romano Pompeu no séc. I antes da Era Comum, e apropriada pelo poeta italiano Petrarca no séc. XIV, por Fernando Pessoa e, por fim, por Caetano Veloso ao cantar a coragem navegante, em jeito de fado brasileiro, em 'Os Argonautas'. Aqui apresento o desenho, o percurso da pesquisa, situando o leitor no que diz respeito ao lócus, aos participantes e aos procedimentos de coleta dos dados e sua análise.

Em seguida, atracaremos no capítulo quatro ao analisar os dados obtidos nas atividades no grupo focal que culminarão, ao abordar as perguntas de pesquisa de dois a cinco, com a comprovação de minhas hipóteses levantadas e abordadas teoricamente no decorrer do texto. Almejo, assim, desvelar as atitudes e escolhas linguísticas dos imigrantes bolivianos que refletem quão afetados são pela consideração do binômio, que se configura em meu objeto de pesquisa, inclusão-identidade na esfera social local.

Por fim, discorro sobre minhas constatações ao 'avistar a Terra' no quinto capítulo. Essas prefiguram as minhas conclusões, ou ausência delas, dada a complexidade da temática proposta nesta dissertação. Também, aproveito o espaço para propor ações afirmativas e um aprofundamento da pesquisa, visando a uma efetiva contribuição para que se atenue o estado de dissabor e frustração dos imigrantes que chegam, sobretudo os em desvantagem social. 
Como uma brisa do mar que sopra sobre o texto, doravante apresentarei ao leitor amigo, ao fim de cada capítulo ou seção do meu texto um quadro que tem como objetivo central sintetizar as principais ideias apresentadas e respaldadas por diferentes pesquisadores.

Almejo com isso propiciar-lhes uma leitura mais fluida do texto além de uma melhor compreensão dos aspectos abordados nesta dissertação, sua importância e implicações. Espero sinceramente que possa desfrutar da leitura de meu texto e que esta cumpra o nobre objetivo de aumentar seu conhecimento sobre o assunto em tela. Espero envolvê-los o bastante para que se apliquem no seu caso a máxima proposta pelo filósofo social chinês do séc. IV a.C.:

\author{
"Conte-me e eu esqueço. \\ Mostre-me e eu apenas me lembro. \\ Envolva-me e eu compreendo".
}

- Confúcio

Quadro 1 - Condensando as ideias iniciais

\begin{tabular}{|l|l|}
\hline Introdução & $\begin{array}{l}\text { Atestei através de uma síntese da histórica narrativa bíblica como o tema da } \\
\text { imigração (trans)nacional é abordada e regulada sob um prisma igualitário. }\end{array}$ \\
\hline Objetivo & $\begin{array}{l}\text { Pretendo com esta pesquisa entender como a questão da (in)visibilidade } \\
\text { sócio-identitária dos imigrantes bolivianos em São Paulo é processada. }\end{array}$ \\
\hline Justificativa & $\begin{array}{l}\text { Demonstrei que um mapeamento de dados legais e históricos, além da } \\
\text { aproximação do pesquisador com o campo de estudo, legitimam a pesquisa. }\end{array}$ \\
\hline Organização & Procurei mostrar como está desenhado meu texto e o que aguarda o leitor. \\
\hline
\end{tabular}

Fonte: Quadro elaborado pelo autor (2015)

Tracemos agora um panorama mais abrangente a partir de uma perspectiva histórica, jurídica e das instituições que acolhem os imigrantes bolivianos na capital paulista. 


\title{
CAPÍTULO 1
}

\section{Contextualização: calibrando a bússola e mapeando a rota}

\begin{abstract}
Barcos errantes, sombras recortadas de vidas almejadas, sonhadas, algumas vezes conseguidas.

Silhuetas que se projectam no futuro, nesse amanhã incerto feito de ocasos inesperados de manhãs de nevoeiro. A tarde cai e o silêncio apoquenta a alma dos navegantes.

Em luta, procuremos a maré, a vaga que empurra, o vento que ajuda, o sol que vitamina, tantas ondas à espera,o farol que ilumina a areia quente do desembarque, os amigos na praia E, façamo-nos ao mar!

\section{— Foz do Douro, Porto}

Foto 2 - Movimente a bússola e o mapa!

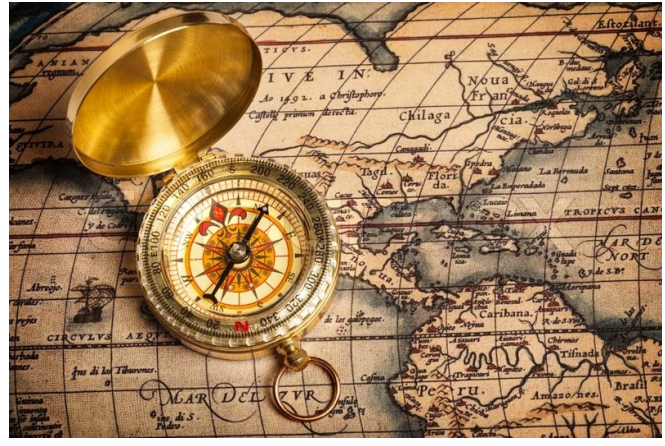
Fonte: Google 6

1.1. Migrações (inter)nacionais: panorama histórico, rotas e rumos ${ }^{7}$

Migração. Do lat. Migratione; Migrāre. Mudar de residência; movimentar-se de um lugar a outro. A história das migrações se confunde com a do homem, pois este é um ser migratório. Assim, para fins de apropriabilidade neste trabalho, defino o vocábulo migração como a mudança de residência de pessoas dentro do mesmo país ou para outro país.

6 Disponível: https://www.colourbox.com/preview/4233973-old-vintage-golden-compass-on-ancient-map.jpg. Acessado em 20/04/2015.

${ }^{7}$ Abordaremos, a partir dessa subentrada e das seguintes neste capítulo, as barreiras legais, históricas e institucionais que advém do trâmite imigratório e seus impactos nos atores implicados. Essa temática se relaciona com a primeira pergunta de pesquisa para este texto. 
Esse termo pode ser desmembrado em outros dois: emigração, quando a pessoa sai de seu país de origem para fixar residência em outro; e, imigração quando a pessoa estabelece-se num eventual país de destino que não seja o seu de nascimento. Igualmente é possível classificar o vocábulo migração em definitiva, sazonal ou temporária; econômica, voluntária ou forçada; legal ou ilegal. Classificação essa que dispensa maiores esclarecimentos.

Segundo dados do 3rd Annual Report on Immigration and Asylum (2012), estima-se que em 2010 havia cerca de 214 milhões de imigrantes no planeta. Desses, 3,2\% residem no Brasil, o que representa uns 6.848.000 imigrantes, sendo que a vasta maioria é procedente de países vizinhos, visto que, em geral, são comparativamente poucos imigrantes que emigram para o além-mar. A partir da tendência estabelecida pela crise mundial de 2008, o Brasil entra na rota de países economicamente vantajosos para os imigrantes. Tanto é assim que, conforme relatório da Organização Internacional para Migração, OIM (2010), a concessão de vistos aumentou em 67\% entre os anos de 2009 e 2010 e cerca de 1,4 milhões de imigrantes obtiveram registros de regularização documental em 2011, o que representa aumento de $52,5 \%$ em relação ao ano anterior.

Além da crise mundial deflagrada em 2008, alisto como possíveis razões que expliquem esse processo imigratório em relação ao Brasil o crescente aumento das desigualdades entre os hemisférios norte e sul, as barreiras comerciais protecionistas, o aumento dos conflitos bélicos e o terrorismo, a movimentação por questões étnico-religiosas, o narcotráfico e correlatos, as catástrofes naturais e a busca pelo eldorado social.

Ao abordar tais questões, Bauman (2007) apresenta princípios relevantes à reflexão:

As guerras e os massacres tribais, a proliferação de 'exércitos de guerrilheiros' ou gangues de criminosos e traficantes de drogas posando de defensores da liberdade, ocupados em dizimar as fileiras uns dos outros, mas absorvendo e, no devido tempo, aniquilando nesse processo o 'excedente populacional' (principalmente os jovens, que não conseguem emprego e não têm perspectivas) - essa é uma das 'quase-soluções locais para problemas globais', distorcidas e perversas, a que os retardatários da modernidade são obrigados a recorrer, ou melhor, acabam recorrendo. Centenas de milhares de pessoas, às vezes milhões, são escorraçadas de seus lares, assassinadas ou forçadas a buscar a sobrevivência fora das fronteiras de seu país. Talvez a única indústria florescente nas terras dos retardatários (conhecidas pelo apelido, tortuoso e frequentemente enganoso, de 'países em desenvolvimento') seja a produção em massa de refugiados (BAUMAN, 2007, p. 39). 
O sociólogo traz à nossa atenção a relação economicista e o fluxo de mão-de-obra barata que estão atreladas à dita globalização que, em última instância, reduz o ser humano a mera mercadoria a ser descartada se não se amolda a essa dinâmica consumista. Harvey (1992) converge com Bauman e amplia a concepção apresentada ao abordar a questão da reestruturação da produção capitalista que afeta de forma nevrálgica os aspectos culturais, políticos e sociais nacionais e transnacionais, e que são paradoxais à ideia da existência de uma aldeia global em oposição à forças políticas e religiosas de outrora (HABERMAS, 1998).

Outro sociólogo que ecoa o pensamento acima é Pierre Bourdieu quando trata da questão de percepção social a partir de uma concepção de identidade como construção simbólica em oposição ao conceito geográfico ou regional (BOURDIEU, 1989). Nesse sentido, e aplicando aos imigrantes, entendo que o sociólogo destaca que, quando eles migram, o fazem munidos de sonhos e com o almejo de voltar à sua terra natal bem-sucedidos economicamente e com sentimento de orgulho e vitória dos obstáculos em sua epopeia.

Seguindo com meu enfoque no Brasil, é sabido que o afluxo de imigrantes ao país traz novamente à tona a necessidade de debates de ordem política, sociocultural e econômica dado o retorno a uma realidade que se considerava pretérita e assentada no território nacional. Entretanto, apesar de existentes no país desigualdades sociais, concentração de riquezas, corrupção a níveis alarmantes e elevada carga tributária, para se mencionar apenas alguns problemas, o Brasil é um país que oferece inúmeros atrativos aos imigrantes. Ao tratar desse tema a pesquisadora Neide Patarra apresenta outro enfoque bastante interessante:

Em função da extensão territorial do país, do tamanho e composição de sua população, da atual etapa de seu crescimento econômico, entre outras especificidades, pode-se afirmar que os relativamente recentes movimentos de brasileiros ao exterior, bem como a entrada de novos imigrantes, principalmente sul-americanos e africanos, não causam um impacto significativo no desenvolvimento nacional. De modo geral, nem a saída de brasileiros nem a entrada de estrangeiros no Brasil atual assumem uma dimensão assustadora ou podem colocar em xeque os esforços de desenvolvimento do país (PATARRA, 2012, p. 88).

Em outras palavras, a autora destaca que o desenvolvimento econômico do Brasil oferece condições de receber e acomodar o contigente de imigrantes que aqui tem desembarcado em anos recentes. No entanto, a mesma pesquisadora pontua a existência de inúmeros conflitos relacionados a esse processo, quando diz: 
O debate e as propostas de políticas de imigração, o tratamento específico de áreas de fronteiras transnacionais, bem como a necessidade de se estabelecer juridicamente o acesso dos migrantes e de suas famílias, documentados ou não, aos serviços públicos, principalmente na área de saúde e de educação, são temas hoje recorrentes e de intensa discussão e ação no contexto regional (PATARRA 2012, p. 85).

A vulnerabilidade das fronteiras brasileiras e a recepção de imigrantes em situação precária, incluindo-se os casos trabalhistas e xenofóbicos, faz do Brasil o eldorado desejado (MARTINS, 1997). Entretanto, a demógrafa e pesquisadora Rosane Baeninger (2012), salienta outro problema que merece atenção. Trata-se das questões políticas e sociais envolvidas. Sobre isso, ela diz:

As políticas para as migrações internacionais estão pautadas no processo de assimilação dos imigrantes na sociedade receptora, no controle dessa população. Esse contingente somente passará a ter direitos à medida que se "integrar", se "assimilar" à sociedade de destino. Tais políticas seguem estatutos de legalização e proteção jurídica a estrangeiros, concedendo, quando assim o fazem, direitos restritos (BAENINGER, 2012, p. 93).

O que chama a minha atenção no alerta acima é o fato de a existência ou ausência de políticas de imigração contribuírem para a promoção ora da cidadania, partindo-se de uma perspectiva inclusiva ora de conglomerados de excluídos que não conseguem acomodar-se social, cultural e financeiramente na sociedade receptora. Não se trata de um problema de somenos importância ou preocupação, pois, segundo dados do Censo Demográfico do Instituto Brasileiro de Geografia e Estatísticas (2010), a cada ano, milhares de imigrantes fixam residência no Brasil. Por exemplo, entre 2001 e 2010, 164.420 imigrantes estabeleceram-se em território nacional em contraste com 65.430 de 1991 a 2000, o que significa aumento de quase $152 \%$ em relação à década anterior. Tal crescimento expressivo no número de imigrantes que optaram por fixar residência no Brasil foi observado apenas na comparação entre as décadas de 1941 a 1950, com a cifra de 35.303, e 1951 a 1960, com 134.567 imigrantes que decidiram viver em nosso país.

Outros dados igualmente relevantes para que sejam pensadas políticas voltadas à questão da imigração no Brasil são os que mostram que foram registrados aumentos no número de imigrantes, por nacionalidade, que fixaram residência neste país. Por exemplo, na comparação entre a primeira e a segunda décadas em pauta, dos Estados Unidos foram 16 mil contra 52 mil, do Japão foram 19 mil contra 41 mil e da Bolívia foram 6 mil contra 15 mil 
imigrantes. Entre tais imigrantes, a maioria tinha entre 20 e 39 anos de idade e apenas 5,4\% tinham 60 anos ou mais de idade, sendo, estes últimos, geralmente, pais dos imigrantes que chegaram primeiro. Os homens também são a maioria e São Paulo é o principal destino, recebendo cerca de $45 \%$ dos imigrantes, seguido pelo Estado do Rio de Janeiro com $16,3 \%$ do total.

Em conclusão, espero ter propiciado um panorama geral da situação da imigração ao Brasil, bem como as rotas e os rumos que que esse fenômeno parece tomar. Os dados apresentados e o pensamento de diversos pesquisadores ligados ao tema convergem para a crescente necessidade de que este seja incluído na pauta política de nosso país, pois não se trata apenas de uma questão envolvendo a acomodação dos imigrantes, mas como ela afetará, quer para o bem quer para o mal, a tais imigrantes e aos próprios brasileiros.

\subsection{Marcos legais: o preamar do imigrante?}

É bem verdade que, embora com benefícios evidentes para a vida marinha, o preamar, ou a maré alta, não beneficia tanto assim os banhistas ou os marinheiros. Pensando no caso dos imigrantes, posso dizer o mesmo no que se refere à legislação para eles no Brasil, pois não temos em nosso país uma lei de migrações, seja para os que emigram ou para os que imigram. O que temos é uma Lei de Estrangeiros, promulgada no ano de 1980, em plena ditadura militar no Brasil. O próprio nome da lei, por si, já me parece vir carregado de (pré)conceitos, uma vez que faz referência ao estranho ou ao que não é, e não pode vir a ser, igual o que, em si, não coaduna com a ideia de humanidade, solidariedade e respeito à dignidade e aos direitos.

Outra razão em relação ao nome da lei, que a meu ver não coaduna com a questão dos imigrantes, é o fato de o Brasil ser, desde os primórdios de sua história, um país notadamente receptor de imigrantes os quais contribuíram de inúmeros modos para o enriquecimento econômico, político, social e, acima de tudo, cultural de nosso país. Assim, por estas e outras razões já abordadas anteriormente, é que urge a construção de novos paradigmas legislativos em prol dos migrantes nacionais e internacionais.

Historicamente é sabido que antes das duas guerras mundiais que assolaram o mundo no século XX, muitos países demonstravam uma postura bastante tolerante e não- 
discriminatória entre o nacional e o imigrante sem estabelecer restrições aos direitos de ambos. No entanto, após as supracitadas guerras, é possível afirmar que houve um nítido retrocesso no cenário mundial nesse sentido. Nesse aspecto, obviamente, o Brasil não vai por um rumo diferente, pois, embora os direitos humanos passem a ser objeto de debates e pauta de discussões em todo o mundo na perspectiva dos direitos à universalidade e indivisibilidade, a legislação aqui continua perpetuando um tratamento segregacionista e desigual aos imigrantes a partir de interesses políticos, militares e econômicos (PIOVESAN, 2004).

A tabela a seguir apresenta de forma sucinta as principais leis promulgadas em nosso país, a partir da Carta Magna de 1934, e suas metas mais relevantes em relação ao imigrante que chega e/ou pretende permanecer no Brasil. Nesta fica evidente o histórico desrespeito e maus-tratos ao imigrante, em especial àqueles que não gozam do perfil de interesse nacional.

Tabela 1 - Principais marcos legais e seus objetivos

\begin{tabular}{|c|c|}
\hline Legislação & Objetivo \\
\hline Constituição de 1934 & $\begin{array}{l}\text { * Institui o sistema de cotas, ou seja, uma corrente imigratória } \\
\text { não pode exceder em } 2 \% \text { do número total da população daquele } \\
\text { país que chegou ao Brasil nos últimos cinquenta anos; } \\
\text { * Veta a concentração de imigrantes no território nacional. }\end{array}$ \\
\hline Constituição de 1937 & * Privilegia a imigração européia e limita outras raças e origens. \\
\hline Decreto $n^{\circ} 383$ de 1938 & * Proíbe aos imigrantes o exercício de atividades políticas. \\
\hline Decreto $n^{\circ} 406$ de 1938 & * O governo decide que raças e origens podem imigrar ao Brasil. \\
\hline Decreto $n^{\circ} 7967$ de 1945 & * Privilegia as características de ascendência européia \\
\hline $\begin{array}{l}\text { Decreto } \mathrm{n}^{\circ} 941 \text { de } 1969 \\
\text { regulamentado pelo } \\
\text { Decreto } n^{\circ} 66.689 / 1970\end{array}$ & $\begin{array}{l}\text { * Os militares a seu arbítrio mudavam as regras em relação à } \\
\text { admissão de imigrantes em território nacional; } \\
\text { * Permite exigências extralegais ante o recrudescimento militar. }\end{array}$ \\
\hline Constituição de 1967 & * Direitos dos migrantes não são calcados nos direitos humanos. \\
\hline $\begin{array}{l}\text { Lei } 6815 \text { de } 1980 \\
\text { Lei do Estrangeiro }\end{array}$ & * Regular a chegada/presença de imigrantes no Brasil. \\
\hline Constituição de 1988 & $\begin{array}{l}\text { * Consigna entre os seus fundamentos a cidadania e a dignidade; } \\
\text { * Promove o bem-estar de todos sem preconceitos de raça, cor, } \\
\text { sexo, origem ou quaisquer outras formas de discriminação; } \\
\text { * Pauta-se pela prevalência dos direitos humanos }\left(\operatorname{art.} 4^{\circ}\right) \text {; } \\
\text { * Promove a igualdade de todos perante a lei }\left(\operatorname{art.~} 5^{\circ}\right) \text {. }\end{array}$ \\
\hline
\end{tabular}


Pela leitura dos objetivos da Constituição de 1988, fica evidente que seus princípios derrogam a retrógrada e obsoleta Lei do Estrangeiro que não contempla a situação os migrantes como fato social orientado sob a égide dos direitos humanos. A atual Lei do Estrangeiro, $n^{\circ} 6.815 / 1980$, regulamentada pela Lei $n^{\circ} 6.964 / 1981$, não se harmoniza com a Carta Magna em vigor, uma vez que essa lei foi concebida com base na Doutrina de Segurança Nacional que via o imigrante como ameaça potencial à ordem nacional.

Portanto, urge a criação de uma lei verdadeiramente pensada para os migrantes, e não com foco no estrangeiro, e cujos princípios fundamentais sejam pautados pela tutela e promoção dos direitos humanos, valorização do migrante, desvinculação do enfoque meramente economicista, criação de espaços dialógicos, preservação da dignidade humana e respeito aos direitos do trabalhador migrante, repressão à xenofobia e crimes afins contra o migrante. Vale destacar que, desde de 2009, tramita, na Câmara dos Deputados e no Senado Federal, o Projeto de Lei do Estrangeiro, PL n ${ }^{0} 5.655 / 2009$, que revogará a Lei $n^{\circ} 6.815$ de 19/08/1980. Em 14/01/2015, a relatora do projeto, Deputada Perpétua Almeida, emitiu parecer favorável à aprovação da Lei de Migração, convergindo com outros pareceres emitidos anteriormente. Como justificativa para seu parecer favorável, a deputada do PCdoB do Acre diz, em parte:

Importante destacar que, na década de 80 , o PIB brasileiro era de apenas US\$ 235 bilhões, número bem menor do que os US\$2,2 trilhões, alcançado em 2013, sendo que esse resultado deverá garantir ao país, em 2014, o posto de $7^{\text {a }}$ maior economia do planeta. O notável incremento da economia brasileira no período entre a promulgação da Lei no 6.815, de 1980, e os dias atuais, a redemocratização do País, o fenômeno da globalização, com a interdependência das economias nacionais, as incríveis transformações no campo das telecomunicações e o aumento dos fluxos de pessoas entre os países são motivos mais do que suficientes para que o Brasil edite uma nova lei dos estrangeiros, que seja capaz de responder adequadamente aos desafios gerados pelos fatos apontados (ALMEIDA, 2015, p. 11).

No esteio da Lei de Migração, em andamento, entendo que seja urgente que esta nova lei contemple, entre outros fatores, a criação de dispositivos para integração cultural dos imigrantes; a regularização dos trabalhadores indocumentados; a aplicação do Estatuto da Criança e do Adolescente no que tange à criação de escolas para todas as crianças e adolescentes imigrantes independentemente da situação jurídica de seus pais; a urgente 
desburocratização dos procedimentos para tramitação e regularização documental dos imigrantes; e a concessão com maior agilidade de um registro de identidade migrante.

Deste modo, o Brasil alinharia sua política em relação aos imigrantes aos instrumentos internacionais e seus direitos, a saber, a Declaração Universal dos Direitos Humanos, de 1948, que sublinha, nos artigos 13 e 15, o direito à liberdade de circulação e a mudar de nacionalidade; o Pacto Internacional dos Direitos Civis e Políticos, de 1966, que reforça o direito de livre locomoção; o Pacto de São José da Costa Rica, de 1992, que, no artigo 22, proíbe a expulsão coletiva de imigrantes e aquela em que o direito à vida ou à liberdade pessoal do(s) imigrante(s) esteja(m) em risco de violação em virtude de sua raça, nacionalidade, religião, condição social ou de suas opiniões políticas; e, a Convenção Internacional sobre a Proteção dos Direitos de todos os Trabalhadores Migrantes e seus Familiares, de 1990, que reconhece mulheres e homens em pé de igualdade como trabalhadores, considera os migrantes como seres sociais e não meros sujeitos econômicos e contempla o migrante como sujeito titular de direitos e do respeito a sua dignidade humana, independentemente de estar em situação regular ou não, de sua nacionalidade, sexo, cor, etnia ou condição econômica.

Ainda no bojo dos marcos legais, destaco: o Acordo de Livre Trânsito e Residência para Nacionais, Decreto $\mathrm{n}^{\mathrm{o}}$ 6.964, de 29 de setembro de 2009, que promulga o acordo sobre residência para nacionais dos estados parte do Mercosul, a saber, Argentina, Brasil, Uruguai e Paraguai, Bolívia e Chile; e, a Lei de Anistia Migratória que possibilita aos imigrantes a regularização de sua situação documental no Brasil. Entre tais leis, chamo a atenção para o número de imigrantes beneficiados, por exemplo, pela Lei 6.964/1981 que concedeu anistia a 27.000 imigrantes, a Lei 7.685/1988 anistiou 36.990, a Lei $9.675 / 1988$ beneficiou a 40.909 e a Lei 11.961/2009 propiciou que cerca de 43.000 imigrantes fossem anistiados e tivessem sua situação documental regularizada perante a justiça brasileira. 
Gráfico 1 - Total de imigrantes anistiados em 2009
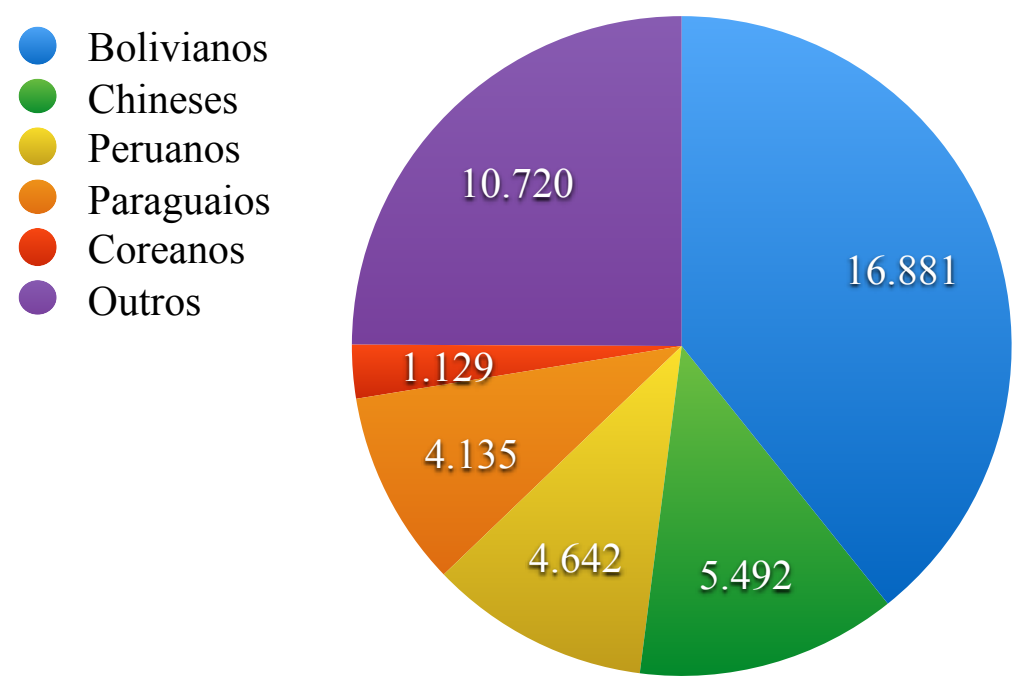

Fonte: Gráfico elaborado pelo autor (2015)

Segundo dados do Ministério da Justiça, conforme dados no gráfico 1, na anistia de 2009, foram regularizados 42.999 imigrantes. Vale ressaltar, ainda, com base no gráfico acima, que, da totalidade dos imigrantes anistiados em 2009, os bolivianos correspondiam a $39 \%$ do total, superando inclusive o total de todas as outras nacionalidades de imigrantes no Brasil. Outro dado interessante é que $60 \%$ dos anistiados são originários de países da América Latina e, dentre esses, os bolivianos representam quase o dobro do total de hispanoamericanos que emigraram para o Brasil e requereram anistia em 2009. Os dados acima apenas corroboram a razão de minha escolha dos imigrantes bolivianos como tema central de minha pesquisa.

A título de informação, alisto na tabela abaixo os tipos de vistos de imigrantes exigidos pela legislação ${ }^{8}$ para fins de regulação de entrada e estadia no país:

\footnotetext{
${ }^{8}$ Segundo a Organização dos Estados Americanos em 2012. Disponível: http://www.justica.gov.br/seus-direitos/ estrangeiros/permanencia/vistos/vistos. Acessado em 22/04/2015.
} 
Tabela 2 - Tipos de visto exigidos para entrada e estadia no Brasil

Tipo de visto

Trânsito

Turista

Temporário

Viagem cultural ou missão de estudos

Viagem de negócios

Artistas ou esportistas

Estudante

Trabalho

Jornalista

Missão religiosa

Permanente

Cortesia a equipe de diplomatas

Oficial

Diplomatas
Legislação: Lei $n^{0} \mathbf{6 . 8 1 5 / 8 0}$

art. $4^{\circ}$, inciso I

art. $4^{\circ}$, inciso II

art. $4^{\circ}$, inciso III

art. 13, inciso I

art. 13, inciso II

art. 13, inciso III

art. 13, inciso IV

art. 13, inciso $\mathrm{V}$

art. 13, inciso VI

art. 13, inciso VII

art. $4^{\circ}$, inciso IV

art. $4^{\circ}$, inciso $\mathrm{V}$

art. $4^{\mathrm{o}}$, inciso VI

art. $4^{\circ}$, inciso VII

Fonte: Tabela elaborada pelo autor (2015)

Quanto à obtenção de nacionalidade brasileira no caso do imigrante, ela pode ser conseguida de modo primário ou originário, ou seja, jus soli, quando é nascido em território nacional, embora de pais imigrantes; e jus sanguinis, quando nascidos no exterior de um ou ambos genitores brasileiros. É também possível conseguir a nacionalidade secundária, que é aquela que se origina de ato jurídico e voluntário denominado de naturalização.

Espero que tenha sido possível, nesta seção, propiciar ao leitor uma visão geral e mais ampla da legislação brasileira que se relaciona ao imigrante, bem como a necessidade de ações políticas conducentes à criação de uma nova lei que contemple os anseios e as necessidades dos imigrantes que aqui aportam em nossos dias. Desejo que essa nova legislação resulte em benefício aos imigrantes e aos brasileiros, assim como o preamar beneficia a vida marinha e produz resultados excelentes para o meio ambiente marítimo. 


\subsection{Imigração boliviana: espraiando-se em São Paulo}

Baeninger (2012) e Teixeira et alli (2012) possuem estudos bastante completos sobre as fases da migração em São Paulo com registro de dados de migrantes nacionais e internacionais que remontam ao ano de 1774, no século XVIII, em que destacam a pertinência do fenômeno migratório paulistano e chamam a atenção para o aspecto interdisciplinar do tema, pois abrange áreas tão distintas como a sociologia, a antropologia, a história, a geografia, a economia e a política.

No caso dos bolivianos, já se passaram 65 anos desde que os primeiros espraiaram-se, ou lançaram-se à praia, por assim dizer, na capital paulista. Os pioneiros eram estudantes em busca de qualificação acadêmica e muitos decidiram estabelecer-se em São Paulo. A imigração boliviana em busca de trabalho em oficinas de costura remonta aos anos 1970, mas é somente a partir da década de 1990, com a melhora econômica no Brasil, que o influxo de bolivianos aumenta substancialmente, saltando de, aproximadamente, $255 \mathrm{em} 1995$ para cerca de 17.897 quatro anos depois, conforme registros da Polícia Federal; em 2007, estimava-se que havia cerca de 200 mil bolivianos indocumentados no país (CYMBALISTA; XAVIER, 2007).

Quando falamos em estimativa da quantidade de bolivianos que se espraiaram na cidade de São Paulo, estamos, na verdade, trilhando terreno arenoso e instável, pois essa é uma informação bastante imprecisa e controversa (SOUZA; PRADO, 2006). Os vereadores da Câmara Municipal de São Paulo, em relatório final sobre a CPI de trabalho escravo, dizem:

O Consulado fala em 50 mil indocumentados; a Pastoral do Migrante, em 70 ou 80 mil; o Ministério Público Federal estima que haja 200 mil bolivianos em São Paulo, entre regulares e irregulares. O Sindicato das Costureiras destaca que, em 1998, havia 140 mil costureiros devidamente registrados trabalhando na cidade; em 2005, esse número caiu para 70 mil. Como não houve um encolhimento desse mercado - ao contrário, ele prosperou e se expandiu - a presidente do Sindicato, Eunice Cabral, calcula que a diferença tenha sido preenchida em grande parte pelos bolivianos em situação irregular. O Sindicato estima que haja 80 mil trabalhadores irregulares, entre as famílias de brasileiros que trabalham em domicílio e bolivianos submetidos às condições descritas (SOUZA; PRADO, 2006, p. 29).

Apesar do aparente desencontro de dados e informações, é consenso que há em São Paulo cerca de 200 mil bolivianos, sendo uns $60 \%$ deles indocumentados ou em situação 
irregular e dois terços deles sendo trabalhadores nas oficinas de costura na capital paulista. Emigra(ra)m por razões aparentemente óbvias dada a precária estrutura social e econômica em seu país aliada à instabilidade política e à miséria que assola boa parte do interior da Bolívia. Convém apresentar brevemente o histórico da indústria do vestuário no Brasil que explica, pelo menos em parte, a razão para a atração dos imigrantes bolivianos a este setor produtivo.

Na década de 1960, os trabalhadores clandestinos em São Paulo constituíam-se de coreanos que eram contratados pelos judeus que dominaram o setor até a década de 1970. A partir dessa época, os coreanos passaram a liderar o setor e contratavam seus compatriotas para trabalhar nas oficinas até que essa mão-de-obra se escasseia e os coreanos passam a contratar os nordestinos (CHOI, 1991). No caso destes últimos, o setor passa por uma crise com a justiça do trabalho, que passa a exigir o cumprimento da legislação em vigor e o pagamento de todos os direitos trabalhistas. Vê-se, portanto, que a oferta de trabalho e mãode-obra no setor de vestuário em São Paulo são elásticos e historicamente mantidos pela exploração humana.

Timidamente, a partir de meados dos anos 1980, e, mais acentuadamente, a partir da segunda metade dos anos 1990, a capital paulista passa a receber imigrantes bolivianos provenientes de estratos sociais mais pobres e cuja personalidade é propícia ao trabalho análogo ao escravo, configurado, assim, por causa das longas jornadas laborais, da submissão a condições insalubres de trabalho e em decorrência da falta de acesso à Justiça do Trabalho. Assim, o ciclo é composto pelo empregador coreano que contrata oficinas de outros coreanos e alguns bolivianos que, por sua vez, contratam bolivianos clandestinos e (i)legalizados. Esse cenário é ideal para os empresários coreanos que assumiram o controle desse setor produtivo na capital paulista, em lugar dos judeus que se ocupam de outras atividades e migram para outro bairro.

Outro aspecto que marca a presença dos imigrantes bolivianos em São Paulo é a maneira como eles são aliciados em seu país de origem. Normalmente, são seduzidos por agenciadores que divulgam as benesses do trabalho no Brasil por meio da mídia, por amigos e parentes que já vivem na capital paulista e alardeiam suas conquistas. Tanto os agenciadores como parentes e amigos, em alguns casos, custeiam a vinda do recrutado e providenciam para ele abrigo precário, alimentação de má qualidade e trabalho em condições insalubres, 
normalmente em locais fechados ou com pouca ventilação, o que contribui para a proliferação de doenças renais, circulatórias e virais, em especial a tuberculose (SILVA, 2008). Acrescido a todo o exposto anteriormente, alisto a promiscuidade, a proliferação de doenças sexualmente transmissíveis, a gravidez precoce e a alta taxa de natalidade. Ainda assim, estabelece-se um relacionamento de apadrinhamento baseado na trípode relação de gratidão, lealdade e paternalismo. Essa evolui para uma relação de servidão trabalhista para (re)compensar o padrinho ou agenciador pelo apoio logístico e pela oportunidade, pois o apadrinhado é obrigado, assim, a sujeitar-se a jornadas de trabalho e exaustivas além de ser sub-remunerado.

Com a concretização da grande depressão que assolou os Estados Unidos e a Europa por uma década, Adams (1931), num intuito de motivar o povo americano, popularizou o que passou a ser conhecido como o American Dream, que era caracterizado pela igualdade de oportunidades que garantiriam riqueza e prosperidade, educação de qualidade, justiça social e ausência de qualquer tipo de discriminação; a realização desse sonho seria possível sobretudo pelo esforço e pela determinação individuais.

Ouso comparar a visão americana propalada na década de 1930 com a que os imigrantes bolivianos têm do Brasil como o seu eldorado, seu Brazilian Dream. São motivados pelos mesmos ideais que motivaram os americanos, e milhares de imigrantes que, ao longo dos anos, elegeram a América do Norte como seu país de residência. Para os imigrantes bolivianos, o Brasil é capaz de oferecer-lhes condições de vida que não se encontra nem no mais otimista horizonte em seu país de origem. Cada trabalhador boliviano sonha em economizar o suficiente para comprar seu imóvel no Brasil, seu carro e sua própria oficina, além de gozar anualmente de férias fartas, ainda que dispendiosas, na Bolívia.

Após considerar brevemente a primeira parte do histórico da chegada dos imigrantes bolivianos a São Paulo, gostaria de continuar a discorrer sobre o tema desde uma ótica familiar e religiosa e como contribuem para sua estada em nosso país.

1.4. Imigração boliviana: o deflúvio familiar e religioso

Como adotei uma analogia marítima para este texto, optei pela palavra deflúvio, que significa "prolongado débito ou perda fluvial", para referir-me ao tema: família dos imigrantes bolivianos. Creio ser este um termo apropriado, pois é assim que percebo as 
relações familiares entre tais imigrantes. Não apenas em referência aos familiares e parentes deixados atrás na Bolívia por ocasião de sua vinda para o Brasil, mas também no que se refere às relações familiares aqui no Brasil, seja com a família imigrada junta ou posteriormente, seja com a família constituída, muitas vezes de forma endogâmica, e, a posteriori, ampliada no Brasil.

As experiências e trajetórias migratórias das famílias de imigrantes bolivianos passam por acessos a redes de apoio bastante similares como já considerei neste texto. A estrutura hierárquica familiar e sua dinâmica impactam de maneira significativa as relações entre os membros dessas famílias a partir de uma perspectiva social e espacial, pois as transformações no seu cotidiano fazem com que vivam em permanente estado de efervescência diante da dupla realidade social com que devem lidar, a da terra receptora e a da pachamama. Como numa embarcação em movimento, a imigração impede, ainda que parcialmente, a manutenção da estabilidade familiar quer com os membros que estão no país receptor quer com os deixados atrás num estado aparentemente imóveis, longe do campo de visão da luneta do emigrado. Todo esse processo é agravado se o acesso aos recursos necessários à subsistência não é alcançado, ou o é parcialmente, dilacerando os sonhos conjuntos.

Todo o turbilhão que procurei descrever resulta em relações familiares bastante fragilizadas entre os imigrantes bolivianos na capital paulista, pois acabam por se deparar com uma realidade e influências culturais e familiares muito distintas das suas. Essa situação ocasiona conflitos e estresse a todos os membros da família que, muitas vezes, não se veem preparados, ou mesmo qualificados, para fazer frente aos novos desafios e problemas. Por esses e outros motivos, é comum entre os homens bolivianos o refúgio na embriaguez e atitudes agressivas e violentas para com as esposas e os filhos.

No caso das mulheres bolivianas, percebo que os aspectos socioeconômicos, a excessiva responsabilidade doméstica imposta a elas visto que essas mulheres precisam assumir o controle da casa e os cuidados aos que compartilham o mesmo imóvel - além da vida conjugal e as relações com seu esposo, a situação jurídica instável e as dificuldades decorrentes da ausência de acesso à saúde são acréscimos às barreiras impostas pelas diferenças culturais e a concepção familiar. Na maioria dos casos, a mulher boliviana deve assumir uma rotina de trabalho igual a do homem e, em adição, dar conta das 
responsabilidades domésticas, o cuidado com os filhos e a administração dos recursos da família imediata, no Brasil, e dos deixados em sua terra natal.

Ao debruçar-me sobre a situação da segunda geração dos imigrantes bolivianos, ou seja, os filhos desses imigrantes que nasceram no Brasil ou chegaram aqui nos primeiros anos de vida, noto um doloroso conflito de adaptação tanto de ordem cultural como social. Por um lado, essas crianças e jovens precisam fazer frente à pressão dos pais para que mantenham laços fortes com a comunidade étnica e, por outro lado, precisam enfrentar os desafios de ingressar num mundo não familiar, alheio a sua formação (bi)nacional e quase sempre hostil.

Como considerarei mais adiante, apresentarei elementos que demonstram como a dinâmica familiar resultante da imigração afeta os bolivianos no que se refere aos construtos identidade, inclusão social e linguagem. Seguindo com a analogia do prolongado débito fluvial, também o aplico à questão religiosa, pois um estudo mais aprofundado da cultura boliviana possibilita, a qualquer pesquisador minimamente interessado, notar que os aspectos culturais, políticos e históricos do povo boliviano estão peculiar e inerentemente imbricados no paradigma religioso. Portanto, não é de estranhar que a religiosidade seja considerada pelo imigrante como um dos instrumentos de recuperação de sua consciência da própria dignidade (LUCÀ, 2007). Em outras palavras, quero dizer que o desenraizamento social e cultural do imigrante boliviano o torna mais vulnerável, desamparado e inseguro, obrigando-o a buscar meios de (re)construir sua identidade, sua visão de mundo e suas representações socioculturais. Não se trata apenas de uma questão multicultural, de integração social, de diversidade religiosa ou laicidade do Estado que os recebeu, mas, antes, de um processo reflexivo na busca do seu $e u$, perdido no amedrontador maremoto da imigração.

Um fato que constato no caso dos imigrantes bolivianos em São Paulo é que a religiosidade constitui um recurso simbólico que contribui para sensação de resposta em sua busca de proteção, dignidade e integração na comunidade local. Não se trata de uma fuga da dura realidade que os confronta diariamente, mas o fortalecimento de uma postura resiliente ante atitudes xenofóbicas, exploração no trabalho e baixa auto-estima.

Em conclusão, é inegável que a composição e manutenção da estrutura familiar e a religiosidade em todas as suas dimensões constituem pilares de sustentação desses imigrantes. 


\subsection{Imigração boliviana: fluxo e refluxo comunitário}

Assim como a maré flui e reflui num movimento contrário e sucessivo a outro, do mesmo modo, a comunidade boliviana em São Paulo vive seus momentos de altas e baixas. Essa alternância não é no sentido de aumentar ou diminuir a quantidade de imigrantes, mas no sentido de que a comunidade vive sob um contínuo ir e vir de novos membros, ou às vezes, antigos que se foram e volta(ra)m.

Outra característica que marca essa comunidade na capital paulista é o fato de viverem, por assim dizer, um enclausuramento dentro das oficinas de costura que, na maioria das vezes, também é sua moradia - compartilhada com outros tantos compatriotas. Nessas circunstâncias, eles têm poucos momentos de lazer além das redes de socialização em locais como a feira da Cantuta, no bairro do Brás, que chega a receber cerca de 5 mil bolivianos aos domingos; eventos realizados anualmente no Memorial da America Latina e os campeonatos de futebol que se espalham por toda a cidade (CYMBALISTA; XAVIER, 2007).

Esses encontros são também ocasiões em que se demarcam as questões de territorialidade não apenas em relação à região onde vivem, mas também quanto a sua organização e associação por origem, sendo a maioria pacenhos, ou de La Paz, seguidos de imigrantes de Cochabamba, Oruro, Potosí, Santa Cruz de la Sierra, etc. No que tange à questão em pauta, é importante ressaltar que a maioria dos membros da comunidade boliviana em São Paulo não migraram dentro da Bolívia, ou seja, saíram das zonas rurais ou vilarejos onde viviam diretamente para a capital paulistana, o que gerou tremendo choque cultural, pois tiveram que enfrentar uma gigante mudança de ritmo na metrópole.

No campo pessoal, muitos imigrantes sofrem com a brusca mudança da língua que, embora pensem que o Espanhol seja a língua materna de todos, equivocam-se, dado que, em virtude da origem rural de grande parte deles, muitos falam o aimara, o quíchua e o guarani boliviano. Além da diferença linguística, há ainda a questão relacionada aos hábitos culturais, à alimentação, às crenças, à ausência e à falta da família e dos amigos, o senso de nãopertencimento, estranhamentos e conflitos oriundos do processo de integração e adaptação ao novo lugar. Acrescido ao mencionado antes, os imigrantes bolivianos precisam lidar, também, com conflitos e choques, de maior ou menor monta, com seus compatriotas. 
Acrescento aos conflitos de natureza pessoal, a situação documental irregular que gera o temor de sofrer sanções legais no Brasil, os incontáveis e cristalizados estereótipos de pobres ignorantes e índios incultos, e o fato de a grande maioria precisar adaptar-se ao novo tipo de trabalho que, algumas vezes, representa um retrocesso quanto a sua capacidade laboral e, portanto, influencia diretamente em sua auto-estima por causa da baixa remuneração e da insalubridade laboral (MARX, 1985). Num esforço de compensar todo esse cenário, os imigrantes procuram diferenciar-se ou sobressair-se como povo trabalhador, o que se contrapõe à suposta indolência dos brasileiros.

Espero que este primeiro capítulo tenha propiciado, ao leitor amigo, subsídios para que se possa entender melhor o universo dos imigrantes através do panorama histórico e dos marcos legais que regulam a entrada e permanência de imigrantes no Brasil. Também procurei proporcionar uma visão geral sobre a comunidade boliviana na capital paulista desde uma perspectiva histórica, familiar, laboral, religiosa e comunitária e como é sua vida afetada por todos esses fatores que guardam relação estreita com sua emigração ao Brasil.

Encerro este capítulo com as palavras de Ralph Waldo Emerson, poeta e filósofo americano do século XIX, que, a meu ver, refletem o conflito que vivem os imigrantes bolivianos antes, durante e com o término de sua epopeia, ou pelo menos parte dela, por ocasião da chegada aos mares paulistanos dantes navegados. Conflito este marcado por desilusões já em sua chegada, desilusões não muito diferentes daquelas de quando partiram.

"Faço as malas, abraço os amigos, embarco num navio e finalmente acordo em [São Paulo]; e ali, a meu lado, vejo o Fato Sombrio, o Eu Triste, implacável, idêntico, do qual eu fugira."

— Ralph Waldo Emerson

Quadro 2 - Sintetizando o panorama

Bauman, 2007 Demonstrei, com dados históricos e demográficos, as implicações Patarra, 2012 sociais e políticas do movimento de acomodação dos imigrantes Baeninger, 2012 bolivianos radicados num bairro centro-sul da capital paulista.

Piovesan, 2004 Apresentei como o tema da imigração boliviana tem sido Almeida, 2015 historicamente tratado pelos diferentes marcos legais brasileiros e como são ineficientes para atingir os fins a que se destinam. 
Partindo de uma perspectiva histórica local e institucional, demonstrei a

Cymbalista, 2007 situação dos imigrantes bolivianos em São Paulo, a partir dos estudos Silva, 2008 de pesquisadores de diferentes áreas, e como a família, a religião e a

Lucà, 2007 comunidade têm papel voltado quer para o bem quer para o mal na estadia de tais imigrantes na cidade.

Fonte: Quadro elaborado pelo autor (2015)

Convém agora, iniciar um percurso teórico que fundamenta minha posterior análise.

\section{CAPÍTULO 2}

\section{Pressupostos teóricos: verificando a ancoragem}

Foto 3 - E se desprende a âncora

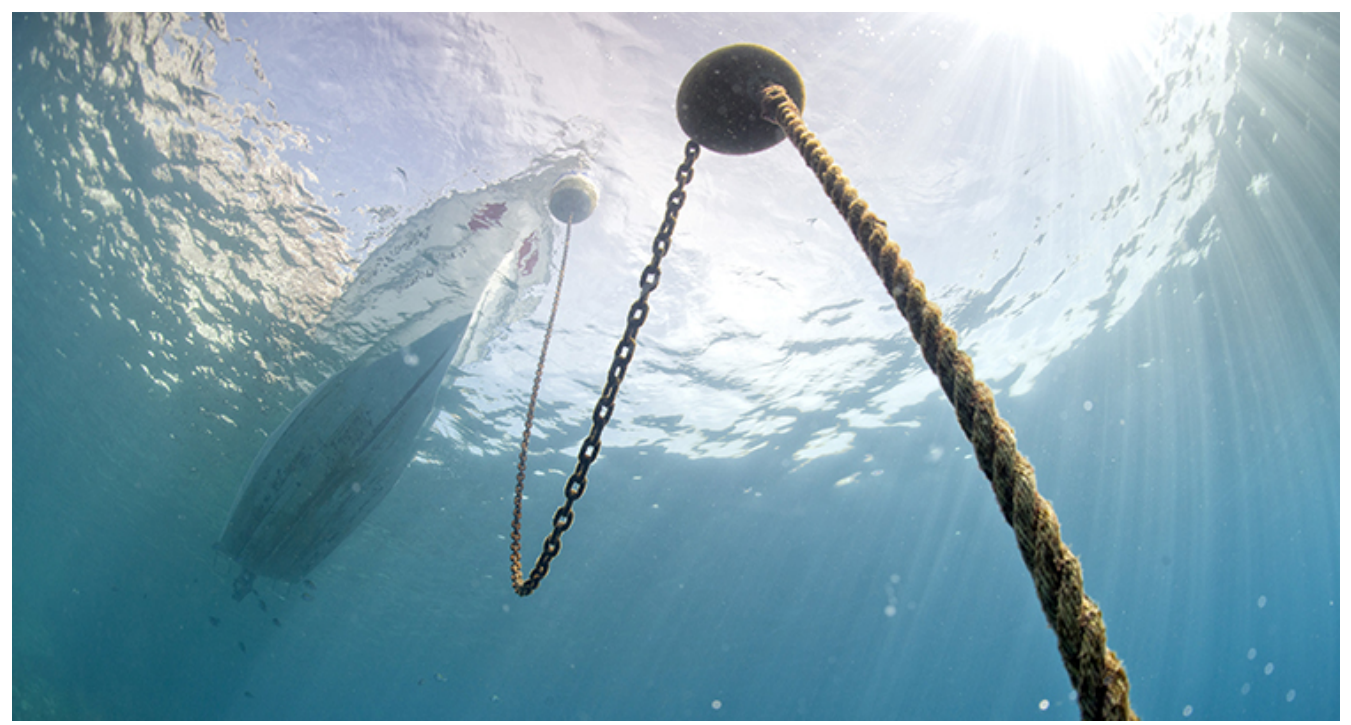

Fonte: Google 9

“Os que se encantam com a prática sem a ciência são como os timoneiros que entram no navio sem timão nem bússola, nunca tendo certeza do seu destino.”

— Leonardo da Vinci

\footnotetext{
${ }^{9}$ Disponível: http://www.bombarco.com.br/comunidade/blog/Manutencao-Equipamentos/tipos-de-ancora-e-cuidados-na-hora-de-escolher-a-do-seu-barco. Acessado em 20/04/2015.
} 
Um navio sem âncora está sujeito a todo tipo de perigos no mar e às intempéries do tempo que colocariam em risco a vida da tripulação e outros passageiros que porventura estejam a bordo. Por essa razão, optei pela analogia da ancoragem neste capítulo, pois entendo que um trabalho acadêmico, ainda que baseado em conhecimento empírico, sem a devida ancoragem científica, é como um navio sem timão nem bússola como epigrafa Leonardo da Vinci na abertura deste capítulo. Para cada âncora de meu texto, proponho uma consideração tripartite que representa os braços e a unha da âncora, ou seja, os itens que garantem a estabilidade da embarcação e o arinque visível para que os navegantes e outros possam facilmente localizá-la.

\section{1. Âncora (i) | Demergeretur doctrinis seiuncta - Ideologias submersas}

Figura 1 - Ideologias veladas

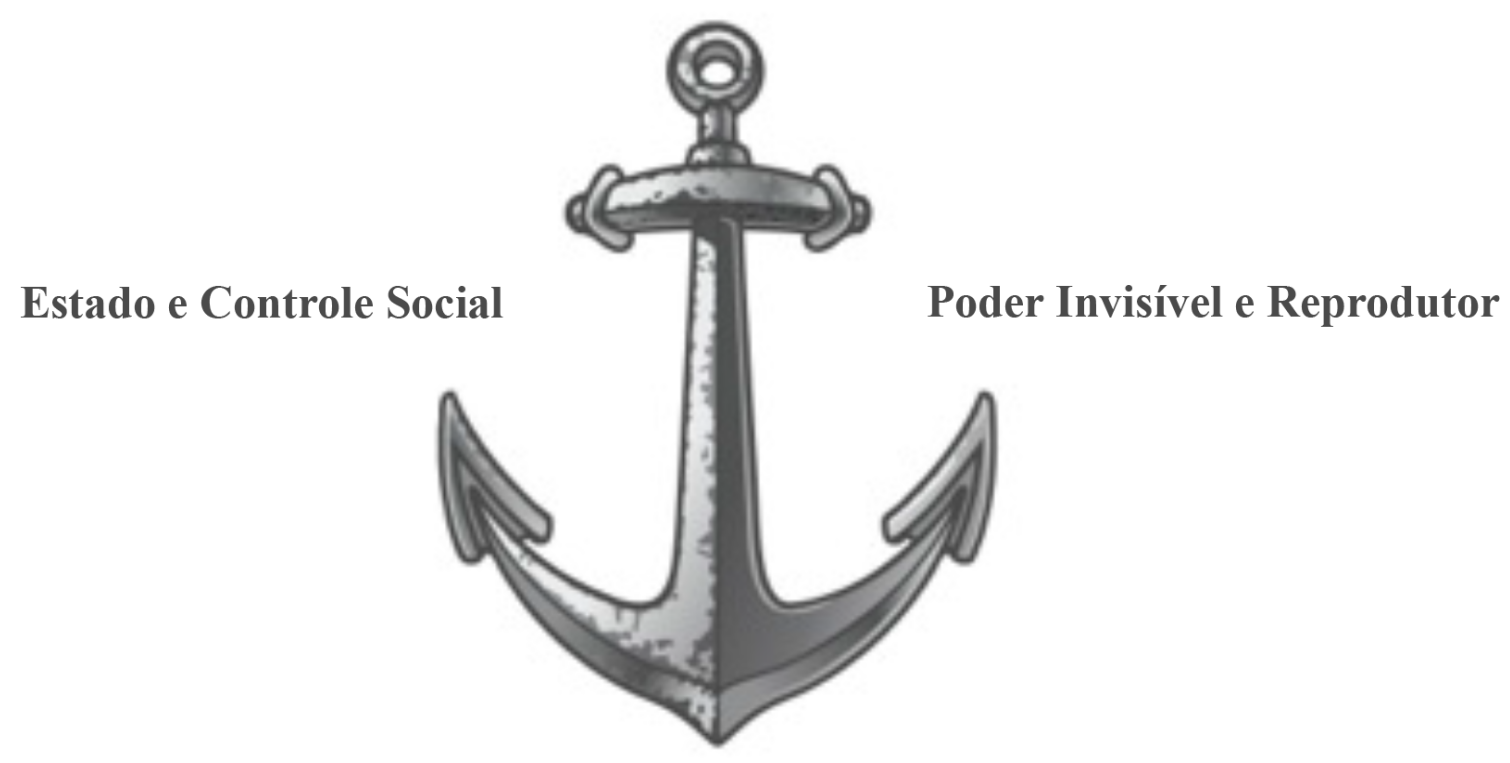

Nova Ordem Econômica

Fontes: Figura elaborada pelo autor (2015) Âncora: Google ${ }^{10}$ 
Como epítome desta seção, apresentarei, à luz das considerações de Althusser (1985) e Thompson (1995), como é operacionalizada pelo Estado a criação, a manutenção e a difusão de ideologias submersas que atuam como forças de controle social. Em Foucault (1996), destacarei o conceito de dominação invisível e, em Bourdieu e Passeron (1973; 1989; 1997), aspectos reprodutores das hierarquias sociais levadas a efeito pelos sistemas públicos e sua organização na sociedade contemporânea. Por fim, revisito Bauman (2003) e Gramsci (1978) ao abordar a influência da nova ordem econômica na vida da sociedade atual.

Sendo assim, com as adriças em punho: içemos as velas e, façamo-nos ao mar!

\subsubsection{Estado e Controle Social}

Quando penso em ideologia à luz dos trabalhos de Althusser e Thompson, vem-me à mente, quase de imediato, a operação do Estado enquanto instituição de (des)organização social. Nessa perspectiva, conseguimos estabelecer uma relação direta com a imigração além das fronteiras nacionais, pois os imigrantes, ao chegar em determinado país, deve[ria]m ser acolhidos inicialmente pelo Estado, cujo papel é manter a organização da sociedade sob sua tutela. Este, o Estado, deve[ria] propiciar a tais imigrantes condições de integrarem-se ao seu novo entorno social, e, ao mesmo tempo, preservar suas identidades e culturas próprias.

Pensando por essa ótica, noto bastante aderência entre o ponto de vista de Althusser e Thompson, pois os dois autores abordam o tema em tela. Thompson (1995), ao definir ideologia, faz uso de uma ampla revisão na literatura filosófica que o leva a conceber ideologia por um viés crítico em que busca estudar, compreender, interpretar e explicar como os processos sociais na era moderna se valem de formas simbólicas para implantar e manter relações de dominação. O mesmo autor entende que a ideologia está urdida em certa estrutura social e, ao mesmo tempo, constitui essa estrutura cuja função é manter e consolidar o capitalismo. Ademais, entende que o contexto social dos indivíduos possibilita que tenham diferentes graus de poder para tomada de decisões e realização de objetivos. Para ele:

A dominação [sob um prisma ideológico] ocorre então quando as relações de poder são sistematicamente assimétricas, ou seja, quando grupos particulares de agentes possuem poder de uma maneira permanente, e em grau significativo, permanecendo inatingível a outros agentes, ou a grupos de agentes, independente da base sobre a qual tal exclusão é levada a efeito. (THOMPSON, 1995, p. 80) 
Em outras palavras, o autor destaca que os conceitos ideológicos excludentes que afetam os imigrantes podem operar por meio de legitimação, dissimulação, unificação, fragmentação e/ou reificação. Tais modos de operação ideológica ajudam a entender como os sentidos servem, em condições sócio-históricas específicas, para manter as relações de poder de dominação que afetam diretamente aos imigrantes. (p. 81-89)

Althusser (1985) converge com o pensamento de Thompson, pois, embora parta do conceito marxista de ideologia, desenvolve, por fim, o seu próprio conceito que é delineado logo no início da obra, em epígrafe, ao citar Marx sobre a reprodução das condições da produção da classe dominante dentro do processo de formação das classes sociais:

Como Marx dizia, até uma criança sabe que se uma formação social não reproduz as condições da produção ao mesmo tempo em que produz não conseguirá sobreviver sequer um ano. A condição última da produção é, assim, a reprodução das condições da produção (ALTHUSSER, 1985, p. 9).

Para Althusser, a história é construída pelas massas que, por sua vez, são ideologicamente manipuladas pelo Estado visando à reprodução da força de trabalho que se perpetua pelo salário, que torna o trabalhador escravizado ao sistema economicista característico da era moderna, cujo objetivo principal é manter a produção, criar regras de respeito à divisão social técnica e submissas à ideologia dominante. Tal divisão de classes faz com que os dominados tenham altamente desenvolvidas, no aspecto social e de trabalho, uma consciência profissional moral, cívica e nacional apolítica e acrítica.

Ambos os autores chamam a atenção para a atuação do Estado em manipular e perpetuar ideologias que, no caso dos imigrantes bolivianos, são profunda e socialmente excludentes. Tal ação estatal gera um menosprezo sistemático pelo imigrante, pois se não puder contribuir com sua força de trabalho para a produção de riquezas é visto como escarro social. A referida aversão ao imigrante será manifestada na repressão, ou simplesmente na desatenção às suas necessidades básicas. Portanto, esse imigrante passa a ser visto como estorvo à manutenção da ideologia dominante e naturalizada; passa a ter sua identidade individual e coletiva fortemente afetadas pelas ações do Estado. 


\subsubsection{Poder Invisível e Reprodutor}

Na sequência, inicio a consideração sobre a obra de Foucault, falando de invisibilidade na concepção foucaultiana ao destacar que, ao ser subjugada, a pessoa é retirada de seu espaço social e é moldada por diferentes formas de dominação. O filósofo trata da questão da vigilância e da ênfase nas mudanças e rupturas basilares que, presumivelmente, ocorreram no século XVII, a partir de arranjos sociais em que muitos vigiavam poucos, para atividades de vigilância modernas, nas quais poucos vigiam muitos. Não cabe a menor dúvida de que Foucault contribuiu de modo importante para a nossa compreensão e sensibilidade sobre o assunto em pauta, considerando como os sistemas de vigilância e as práticas modernas que se expandem rapidamente e afetam a todos, inclusive aos imigrantes bolivianos no bairro Bom Retiro em São Paulo. É evidente que tal ação ocorre de maneira invisível à sociedade, nos moldes do modelo de controle proposto pelo panóptico de Jeremy Bentham (BENTHAM, 2000). Nesse modelo, as pessoas são vistas sem poderem ver, o que possibilita a ação coerciva do Estado ao perceber ameaçado seu controle e sua capacidade de dominação; a não adesão ou insubmissão a esse sistema e padrão de comportamento resulta em exclusão social. Foucault (1996) chama esse controle de tecnologia política que domina e instrumentaliza os homens, e que hoje é muito mais invisível e coerciva por causa das tecnologias atuais, como câmeras e satélites. Ademais, ao falar sobre esse poder invisível que está presente em um discurso que traduz sistemas de dominação social, Foucault diz que:

\footnotetext{
A produção [desse] discurso é controlada, selecionada, organizada e redistribuída por certo número de procedimentos que tem por função conjurar seus poderes e perigos, dominar seu acontecimento aleatório, esquivar sua pesada e temível materialidade (FOUCAULT, 1996, p. 8-9).
}

Concordo com Foucault, uma vez que na sociedade paulistana os procedimentos de exclusão do imigrante boliviano se dão por meio do discurso, visto que reside na palavra o lugar onde se exerce a separação dos tipos sociais, nacionais e imigrantes

Portanto, Foucault (1996), ao pensar sobre as relações de poder, procura compreender como as percepções sociais são constituídas e como a visão social mudou seu trato da punição. Como o acesso ao saber e a capacidade de articulação para fins de dominação por parte do Estado conseguiu-se produzir um discurso autorizado sobre o prisioneiro, mostrando- 
se mais eficaz por ser menos custoso e produtor de comportamentos, que teve sua tentativa de materialidade na construção do panóptico benthaniano. Assim, como filósofo, ele se interessa pelas relações discursivas sobretudo em sua forma físico-material e pelos desdobramentos que ela terá ao constituir poder. Poder este que, para Foucault, existe enquanto prática e exercício ordinário, não emana de entidade superior alguma e estabelece relação dicotômica entre o bem e o mal, o dominado e o dominador, a sociedade como um todo e o Estado. Nessa concepção, ele mesmo explica:

O poder funciona. $\mathrm{O}$ poder se exerce em rede e, nessa rede, não só os indivíduos circulam, mas estão sempre em posição de ser submetidos a esse poder e também de exercê-lo. Jamais eles são o alvo inerte ou consentidor do poder, são sempre seus intermediários. Em outras palavras, o poder [que] transita pelos indivíduos, não se aplica a eles (FOUCAULT, 2002, p. 35).

O poder concebido por Foucault (2002) e emanado, por assim dizer, do Estado confere autoridade a que certas entidades ou indivíduos na sociedade o exerçam invisivelmente agindo como intermediários do Estado. Pensando na situação dos imigrantes bolivianos, entendo que aqueles na comunidade local que exercem esse poder em relação a tais imigrantes o fazem porque se sentem autorizados, legitimados pelo ausente/conivente Estado.

Culmino o pensamento de Althusser, Thompson e Foucault apresentando agora, a partir da perspectiva de Bourdieu, a denúncia sobre os aspectos reprodutores das hierarquias sociais levadas a efeito pela forma de organização na sociedade capitalista contemporânea, em especial pelos efeitos prejudiciais da globalização, da adoção e do avanço de políticas neoliberais cujos preceitos se baseiam na premiação meritocrática e de ascensão social.

Bourdieu (1997) amplia tais posicionamentos ao abordar a questão do capital cultural e social que são legitimados de acordo com o poder aquisitivo e com conjuntos de conhecimentos socialmente valorizados detidos por alguns seletos indivíduos na sociedade. Todo o restante é ato de exclusão, como acontece com os imigrantes que aqui desembarcam. Bourdieu e Passeron (1973), ao falar de desigualdades sociais, dizem que:

[...] oferecer a todos uma tecnologia de trabalho intelectual, inculcar métodos racionais de trabalho será uma maneira para reduzir as desigualdades [...]. E porque conhecemos as leis da reprodução é que temos alguma chance de minimizar a ação reprodutora [do Estado]. (BOURDIEU; PASSERON, 1973, p. 77) 
Embora apontado o caminho no fragmento acima, esse princípio não é levado a termo no caso dos imigrantes bolivianos em São Paulo. O espaço social ocupado por esses imigrantes é construído à base de diferenciação e hierarquia, ou seja, há uma arena de luta de forças neste espaço em que, ao detentor delas, é conferida a definição de posições relativas. Discordo do autor quando ele usa o termo 'relativas', sugerindo a possibilidade de mudança nesse embate, bem como se a ciência desse processo o tornasse permeável à ação dos desfavorecidos, pois isso não é o que se observa nesse caso (BOURDIEU, 1989).

Portanto, os conceitos de Bourdieu trazem à baila um tipo de violência que é atrozmente cometida contra os imigrantes em tela, pois se trata de uma nova dimensão da noção de poder exercido sem que os dominados tenham a alternativa de consentir ou não. É invisível e coercivo, conforme salientou Foucault (2005). Bourdieu (1989) amplia a noção de dominação ao falar de sistemas simbólicos que, embora sejam por excelência cunhados para integração social, são apropriados por essas forças hierarquicamente dominantes e concebidos como estruturados e estruturantes e são essenciais para:

[...] o exercício da dominação na medida em que são instrumentos de imposição ou de legitimação da dominação, que contribuem para assegurar a dominação de uma classe sobre outra [...] dando o reforço da sua própria força que as fundamenta e contribuindo assim, [...] para a domesticação dos dominados (BOURDIEU, 1989, p. 11).

Aproprio-me agora de outros conceitos bourdieusianos para discorrer brevemente sobre o meu olhar no que concerne à questão dos imigrantes bolivianos em São Paulo. Tratase primeiramente do conceito de excluído do interior em que o autor, ao abordar a temática da exclusão social, caracterizada como forma simbólica de violência, fala daqueles cuja cumplicidade é extorquida e não lhes resta outra opção a não ser a de permanecer no âmago da teia de exclusão que os domina, os envolve, os controla. Em segundo lugar, vale chamar a atenção do leitor deste texto para a noção de habitus o que, para Bourdieu, se relaciona com a reprodução de comportamentos sociais e a incorporação de estruturas sociais sem que ao imigrante tenha sido dada a oportunidade de decidir a partir de uma razão prática e decisão lógica, ou seja, ao imigrante são determinados quase na totalidade quais valores deverá adotar, quais as formas em que poderá se movimentar, de que maneiras poderá perceber o mundo a sua volta e como se organizar nessa nova sociedade que se arroga acolhedora. 
Em conclusão, tanto os preceitos de Michel Foucault como os de Pierre Bourdieu no que diz respeito aos atos de dominação social são fundamentais para que se entenda de forma mais cristalina o que ocorre com os imigrantes bolivianos. $\mathrm{O}$ fato desse poder, ou força de dominação, materializar-se de forma invisível (FOUCAULT, 1996) e hierarquicamente estruturada e estruturante (BOURDIEU, 1973; 1989; 1997) torna-o quase impossível de ser penetrado pelos imigrantes, em especial os desfavorecidos.

\subsubsection{Nova Ordem Econômica}

Como terceiro elemento que compõe essa âncora, prefiro iniciar esta consideração com o conceito que extraio de Gee (1996) quando apresenta-nos o fato de que vivemos em um mundo em que já está estabelecida uma nova ordem de trabalho como parte de uma profunda reestruturação das relações nas mais diferentes esferas da sociedade moderna. $\mathrm{O}$ autor, em sua obra, aponta para a influência do capitalismo rápido com sua estrutura desenhada para demandar maior profissionalização para fazer frente ao apelo mercadológico e às estruturas hierárquicas das corporações atuais. Esse fenômeno igualmente foi apresentado por Gramsci (1978), quando aborda o uso que o neoliberalismo capitalista faz da mídia para a preparação da mão-de-obra. Em linhas gerais, ambos os autores apresentam essa nova ordem econômica a partir da perspectiva de uma crítica radical ao economicismo moderno.

Como o tema central desta seção se relaciona com as ideologias subjacentes às práticas sociais excludentes e que afetam diretamente o imigrante boliviano na capital Paulista, amplio o tema ainda em Gramsci uma vez que, para ele, a ideologia está relacionada com o conceito de hegemonia construída pelo consenso, visando a construção de uma civilização cosmopolita sem mecanicismos e mais humanista em que a primazia seja dada à igualdade e à inclusão social de quem quer que faça parte dessa sociedade. Esse conceito também se relaciona com os movimentos das forças sócio-históricas e não com um mero conjunto de ideias abstratas ou normas lógicas. Ainda sobre ideologia, Gramsci complementa:

É [...] uma concepção de mundo que se manifesta implicitamente na arte, no direito, na atividade econômica, em todas as manifestações de vida individuais e coletivas [...]. É sua situação real em determinado tipo de sociedade e o princípio que a norteia é o de que as idéias não nascem de outras idéias, que as filosofias não nascem de outras filosofias, mas são as expressões sempre renovadas do desenvolvimento histórico real. (GRAMSCI, 1978, p. 16, 22). 
O filósofo lembra ainda que todas as nossas ações são atravessadas por uma significação reflexiva e teórica, que a posteriori se constitui em uma práxis, ou seja, uma prática informada pelo conhecimento, pensada, reflexiva, não mecânica, não instintiva, mas produzida pelo exercício da subjetividade. Concordo com o autor, pois, por razões ideologicamente pensadas e desenhadas, os imigrantes são despojados dessa práxis.

Em outras palavras, ouso afirmar que, para que uma sociedade seja eminentemente inclusiva e fundada em princípios igualitários, seu modus operandis deve ser notadamente dialético e dialógico a fim de possibilitar a tomada de consciência de coesão social, não de modo instrucional e acrítico, o que contribuiria para a não discriminação e desigualdade social.

As instituições de acolhimento, conforme considerei no primeiro capítulo desta dissertação, não devem constituir-se em mediações para a sistematização de uma ideologia dominante sem, contudo, propiciar aos seus pares e aos imigrantes a formação crítica e conduciva a uma contra-ideologia, visando a libertação e a construção da autonomia. Tais instituições devem integrar todas as pessoas em todas as dimensões de sua existência social como na arte, cultura, política, ética, etc. proporcionando, assim, uma experiência unitária que se contrapõe ao conceito de dominação, alienação. Trata-se, então, de uma ideologia que deve ser orgânica, ou seja, construída pela sociedade à base do bom senso, do consenso e do bem-estar social, diferentemente daquela marcadamente artificial e cuja intenção é apenas de dominar a sociedade através de um conjunto de valores alheios. Portanto, para Gramsci:

É necessário, por conseguinte, distinguir entre ideologias historicamente orgânicas, isto é, que são necessárias a uma determinada estrutura, e ideologias arbitrárias, racionalistas, desejadas. $\mathrm{Na}$ medida em que são historicamente necessárias, as ideologias têm uma validade que é validade psicológica: elas organizam as massas humanas, formam o terreno sobre o qual os homens se movimentam, adquirem consciência de sua posição, lutam, etc. $\mathrm{Na}$ medida em que são arbitrárias, elas não criam senão movimentos individuais e polêmicos (GRAMSCI, 1978, p. 62, 63).

Neste sentido, a ideologia tem papel decisivo, essencial na organização social, não só por possuir força real, mas também porque qualquer modificação estrutural para a manutenção ou modificação das condições de dominação não pode acontecer sem a intervenção dos elementos ideológicos. No entanto, o referido autor alerta para o uso acrítico 
e baseado em interesses arbitrários que operam como forças de dominação e opressão sobre os desfavorecidos.

Passo, a seguir, a fazer uma breve consideração sobre a obra de um sociólogo da atualidade, Zygmunt Bauman. Falar de ideologia em Bauman e relacioná-la aos imigrantes bolivianos parece não ser tarefa fácil, mas atrevo-me a dizer que o autor pode contribuir de modo significativo ao entendimento da situação dos imigrantes na cidade de São Paulo.

Inicio por destacar o seguinte fragmento:

Em vez de homogeneizar a condição humana, a anulação tecnológica das distâncias temporais-espaciais tende a polarizá-la. Ela emancipa certos seres humanos das restrições territoriais e torna extraterritoriais certos significados geradores de comunidade - ao mesmo tempo que desnuda o território, no qual outras pessoas continuam sendo confinadas, do seu significado e da sua capacidade de doar identidade (BAUMAN, 1999, p. 24).

Para o sociólogo, a polarização de poder e, consequente, [re]transmissão de ideologias dominadoras e massacradoras de identidades é inevitável, dado que a existência humana está entrelaçada com o cotidiano de todos diante da anulação de barreiras temporal-espacial. No entanto, no caso dos imigrantes, a construção de um mundo simétrico e ultra-organizado, quer seja em sua nova pátria quer em sua terra natal, não se concretiza. Nesse sentido, retomo o pensamento de um filósofo americano do séc. XIX, Ralph Waldo Emerson, para descrever a situação derradeira desses imigrantes que têm seus sonhos despedaçados ante o poder exercido pelas ideologias de sua nova sociedade, que, ao final, fazem-no sentir como se estivessem sobre uma fina casca de gelo e que, se pararem de se movimentar, ela rachará, afogando-os.

Bauman ilustra de forma gráfica o pensamento de Emerson ao falar do pesadelo da modernidade sólida, baseada na ideia de ser organizada, produtora de justiça no mundo, garantidora de qualidade de vida das pessoas e controladora de um capitalismo civilizado, rico, igual e justo. Esse sonho materializado passa a ruir desaguando em um Estado racional incapaz de resolver os problemas que surgem. Isso afeta diretamente os imigrantes bolivianos que saem de sua terra natal em direção a outras, além de suas fronteiras, em busca desse sonho oferecido pela modernidade, o qual não é concretizado em seus países de origem.

O que aconteceu, segundo Bauman (1999), é que o estado democrático, durante anos, se ajustou à promessa e à responsabilidade de proteger e prover bem-estar a qualquer coletivo 
contra a desgraça individual. As pessoas tinham sentido de pertinência e solidariedade. Lamentavelmente, com as mudanças da modernidade sólida, os problemas se avolumam levando as pessoas a tomarem decisões drásticas a fim de assegurar, em muitos casos, como no dos imigrantes bolivianos, mínimas condições de sobrevivência.

Entretanto, a situação é ainda mais grave no caso de imigrantes, pois são desprovidos de sua pertença, sua identidade social e cultural, como demonstrarei, mais adiante neste texto, na análise de meus dados. Os imigrantes precisam fazer frente a todas as mazelas econômicas a que são submetidos, primeiro, em seus países de origem e, em seguida, no país(es) que elegeram para serem acolhidos. Essa conjuntura, em conformidade com Bauman (2010), gera, portanto:

\begin{abstract}
Uma pessoa humilhada ao receber a mensagem, por palavras ou ações, de que não pode ser quem pensa que é. Essa humilhação gera preconceito e ressentimento. Numa sociedade individualista como a nossa, este é um tipo venenoso e implacável de ressentimento e uma das mais comuns causas de conflito, rebelião e revolta. Ela destrói a auto-estima e nega o reconhecimento, recusa o respeito e aplica a exclusão; substitui a exploração e assume a discriminação como explicação mais comumente usada para justificar o rancor (BAUMAN, 2010, p. 42).
\end{abstract}

Esse mal-estar do pós-moderno é convertido na angústia de ser livre das tradições, da obediência a algo ou alguém, exceto da obediência à lei de mercado. Assim, o imigrante descobre que ser livre é um peso gigantesco, pois não pode confiar em nada nem em ninguém, muito menos ainda no(s) Estado(s), plural para o imigrante dada a sua dupla pertença. Essa condição a que chega o imigrante [pobre] é aclarado pelo excerto de Bauman (op.cit.):

O propósito primário, definidor, da preocupação do Estado com a pobreza, não está mais em manter os pobres em boa forma, mas em policiar os pobres, mantendo-os afastados das ações maléficas e dos problemas, controlados, vigiados, disciplinados. As agências para se lidar com os pobres e desocupados não são uma continuação do Estado social, salvo pelo nome, elas são em tudo os últimos vestígios do panóptico, de Jeremy Bentham, ou uma versão atualizada dos abrigos para pobres que precederam o advento do Estado de bem-estar. Essas instituições são muito mais veículos de exclusão que de inclusão; ferramentas para manter pobres fora, e não dentro (p. 52).

As ponderações de Bauman, embora dirigidas originalmente aos pobres, aplicam-se com igual força aos imigrantes bolivianos que aqui desembarcam em situação de desfavor. 
Concluo com outro excerto de Bauman (op.cit.) que aborda a exclusão daí advindas:

O que hoje se chama de Estado de bem-estar é apenas uma geringonça para combater o resíduo de indivíduos sem capacidade de garantir sua própria sobrevivência por falta de recursos adequados. Trata-se de agências para registrar, separar e excluir essas pessoas - e mantê-las excluídas e isoladas da parte dita normal da sociedade. Essas agências administram esse gueto sem paredes, um campo de prisioneiros sem arame farpado, embora densamente contido por torres de vigia [econômicas] (p. 53).

No caso dos imigrantes bolivianos, as chocantes palavras de Bauman aplicam-se com força e contribuem para sua exclusão, guetorização e aprisionamento na comunidade local.

Meu objetivo neste primeiro processo de ancoragem desta dissertação foi mostrar como as ideologias contribuem para um total estado de dominação sobre os imigrantes bolivianos em São Paulo. É evidente que fiz uso do conceito crítico na acepção do termo, pois entendo que este se refere a um conjunto de ideias e ações sociais que geladamente servem como instrumento de dominação e agem dissuasivamente e de forma prescritiva alienando a consciência do imigrante. Entendo que cada um dos pensadores sociais dos quais me vali para ancorar essa subseção do texto tem contribuições bastante significativas para o tema objeto de minha pesquisa.

Quadro 3 - Compendiando as ideologias emersas

Com base nos autores citados, mostrei a ineficácia do Estado em

Althusser, 1985 cumprir com seu papel social e como tal negligência contribui para a

Thompson, 1995 desestruturação da sociedade local com enormes prejuízos para os imigrantes bolivianos e para os nacionais que aqui (con)vivem.

Destaquei como o filósofo e o sociólogo em pauta salientaram a não

Foucault, 1996 adesão e insubmissão ao invisível sistema de controle Estatal, bem

Bourdieu, 1989 como a não posse do requerido capital cultural e social impede os imigrantes bolivianos de trânsito e acesso a bens e serviços básicos. 
Apresentei que o princípio homogenizador do economicismo moderno,

Bauman, 2010 criticado pelos pesquisadores sociais citados, apenas serve aos Gramsci, 1978 interesses da reprodução de desigualdades e injustiças sociais que afetam sobremaneira aos imigrantes bolivianos.

Fonte: Quadro elaborado pelo autor (2015)

Antes de prosseguir com a consideração dos processos sociais de inclusão e/ou exclusão, na próxima seção, concluo esta com a citação de um renomado escritor Romeno que, ao meu ver, se aplica com propriedade ao caso dos imigrantes bolivianos em São Paulo:

Ideologias nos separam, sonhos e aflição nos unem.

— Eugène Ionesco

2.2. Âncora (ii) | Inclusão dos (in)visíveis

Figura 2 - Inclusão hoc opus, hic labor est

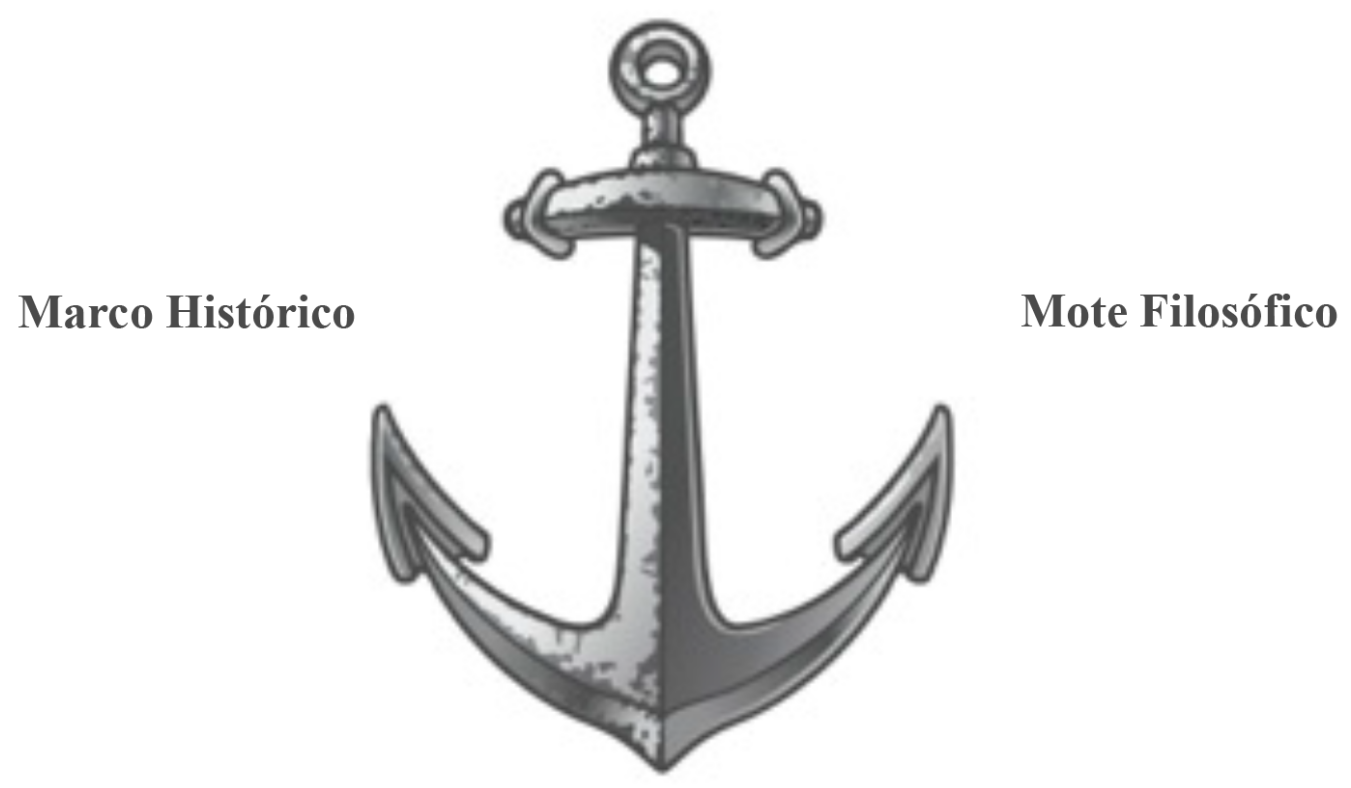

Axioma Sociológico

Fontes: Figura elaborada pelo autor (2015) Âncora: Google ${ }^{11}$

${ }^{11}$ Disponível: http://seapunk.com.br/camiseta-seapunk-ancora.html. Acessado em 20/04/2015 
O rosto, ou o corpo do déspota ou do deus, tem uma espécie de contra-corpo: o corpo do duplicado, ou, ainda melhor, do excluído.

— Deleuze e Guattari, Mil Platôs, v.1

Diskin (2008) conta que, após terminar uma pesquisa etnográfica junto a tribo Ubuntu, na África, o antropólogo decidiu presentear as crianças da tribo com uma cesta de doces e guloseimas enquanto esperava seu transporte. Colocou a cesta embaixo de uma árvore a certa distância e orientou as crianças que, ao seu sinal, deveriam correr o máximo que pudessem; o primeiro a alcançar a cesta seria o vencedor e ganharia todo o seu conteúdo. Alinhadas numa marca no chão, todas as crianças aguardavam o sinal do antropólogo. Quando o deu, todas as crianças deram-se as mãos e correram em direção à árvore. Ao alcançar a cesta, distribuíram o prêmio entre todas. Intrigado, o antropólogo quis saber porque não competiram para que apenas uma ganhasse todos os doces e guloseimas. A surpreendente resposta das crianças foi: "Ubuntu, tio! Como uma de nós poderia ficar verdadeiramente feliz se todas as outras ficassem tristes?” Desconcertado, o antropólogo aprendeu uma última lição com as crianças da tribo cujo nome, Ubuntu, significa: Sou quem sou, porque somos todos nós.

Optei por abrir esta seção com o significante e intrigante relato de Lia Diskin, pois acredito que a lição ensinada ao antropólogo pelas crianças da tribo Ubuntu resume de forma gráfica o que me inquieta nessa pesquisa com os imigrantes bolivianos em situação de exclusão e invisibilidade na comunidade local, num bairro paulistano.

É óbvio que o conceito, [quase] filosófico, que subjazeu à prática das crianças da tribo Ubuntu pode parecer utópico e impraticável para a sociedade ocidental contemporânea dadas as circunstâncias materiais e imateriais em que se encontra a tessitura social neste lado do planeta. Entretanto, todos concordamos, ainda que inconscientemente, que se trata de um excelente modelo de inclusão e partilha com o outro. Ações como essas são o que esperaríamos de nações que se arrogam civilizadas e que recebem, ou pelo menos toleram e permitem em seu meio, imigrantes das mais diversas partes do mundo, em especial os em desvantagem socioeconômica.

Abordarei, nesta segunda seção, como o construto inclusão deve ser analisado a partir do marco histórico, do mote filosófico e do axioma sociológico. 


\subsubsection{Marco Histórico}

Embora prefira neste texto optar por abordar a questão da imigração boliviana pelo viés da inclusão, estou ciente do ônus que a escolha desse viés deixa o outro, igualmente importante, de lado. Assim, antes de abordar o aspecto histórico, é providencial destacar que falar em inclusão implica abordar, ainda que de modo conciso, o tripé excludente: estereótipo, preconceito e discriminação (SEMPRINI, 1999; TOURAINE, 1998; 1999).

Estereotipar alguém significa criar em torno de alguém, individual ou coletivamente, uma imagem pré-concebida, um juízo de valor ora positivo ora negativo. Quando aplicado negativamente, um estereótipo cristaliza-se, torna-se uma verdade absoluta e move ou induz os que causam e/ou aceitam a imagem estereotipada a tentar neutralizar, invisibilizar o objeto do estereótipo. De um ponto de vista (meta)cognitivo, um estereótipo classifica, categoriza e internaliza-se de modo acrítico e sem reflexão prévia nos seus perpetradores que, em última instância, servirão como geradores de preconceito, ódio e discriminação.

Quando pensamos em preconceito, podemos buscar a raiz que provém do grego antigo, $\beta \dot{\alpha} \rho \beta \alpha \rho o \varsigma$, e significa não-grego ou estrangeiro cuja língua materna não era a língua grega. No Império Romano, a expressão passou a ser usada com a conotação pejorativa de incivilizado ou aquele que não possui civilidade, referindo-se aos que não compartilhavam os mesmos hábitos e costumes. Assim, o termo preconceito assumiu ao longo dos anos, relação com uma atitude negativa, hostil, inflexível, ilógica, incoerente e avessa dirigida a um grupo social quer a indivíduos quer a um coletivo pertencente a um grupo específico. Uma característica marcante do preconceito é aquela cimenta suas bases em juízos falsos e infundados. Historicamente, um preconceito evolui alcançando níveis de intolerância, ódio irracional e aversão a outras raças, nacionalidades, classes sociais, etc. Outro detalhe sombrio é o fato de que o preconceito pode ser velado e manifestar-se de modos sutis e imperceptíveis.

Diferentemente de estereótipos e preconceitos que podem ser apenas construtos abstratos, a discriminação é a materialização dos anteriores, ou seja, trata-se de uma posição estereotipada e preconceituosa levada à cabo, posta em ação. É o ato de distinguir, segregar, excluir, privar de direitos, diferenciar, e sempre com a intenção de menosprezar, inferiorizar, causar dano físico, mental e emocional, impedir o acesso a espaços simbólicos, apartar. 
Discriminar implica não aceitar o que é diverso, diferente e, se não for possível homogeneizar, envidam-se esforços para neutralizar, invisibilizar, eliminar, expurgar.

Vale ressaltar, portanto, que, a menos que o tripé apresentado acima seja exposto, denunciado e desconstruído, o ato de incluir torna-se pouco viável, pois nega-se o princípio básico de humanidade que é o ato de respeitar o outro em sua diferença.

Antes de prosseguir a discussão, defino o termo inclusão inicialmente:

Def. INCLUIR: Do lat. includere, com mudança de conjug. Verbo transitivo direto: 1. Compreender, abranger; 2. Conter em si; envolver, implicar; 3. Pôr dentro de carta, bilhete, memorando, etc.; 4. Fazer constar de uma lista, de uma série, de uma enumeração; relacionar, arrolar; Verbo transitivo direto e indireto: 5. Inserir, intercalar, introduzir; Verbo pronominal. 6. Pôr ou fazer pôr o seu próprio nome, a sua pessoa, numa lista, série, enumeração; 7. Estar incluído ou compreendido; fazer parte; figurar entre outro(s); pertencer, juntamente com outro(s); 8. Fechar-se, encerrar-se. [Part.: incluído e incluso] (grifos do autor).

Dicionário eletrônico Aurélio, versão 2.2.1 (156) (C) 2005-2011 Apple Inc.

Da definição acima, infere-se que o próprio termo em Português, em especial na definição $\mathrm{n}^{\circ} 7$, contempla a ideia de estar, o que pressupõe um processo contínuo. Também aplica-se a figurar entre outro(s), pertencer, juntamente com outro(s). Entendo eu que esse é exatamente o desejo de todos os que estão socialmente apartados, em especial os imigrantes bolivianos que desembarcam em São Paulo no fim de uma jornada e início de outra.

Entendo que a definição proposta pelo dicionário Aurélio encontra liga com o evento narrado por Lia Diskin no início deste capítulo. O processo de inclusão precisa ser consciente, criativo, real e, principalmente, individual e, ao mesmo tempo, coletivo — necessita de ações eficazes que garantam o desenvolvimento intelectual, social, afetivo e profissional daqueles a quem se destina. E é exatamente isso o que concebem as crianças da tribo Ubuntu, ou seja, mesmo as mais fracas ou corredoras lentas, são incluídas consciente e socioafetivamente.

Historicamente, a proposta de inclusão surgiu com a chegada do século XX, momento em que se chegou ao consenso de que havia, na sociedade moderna, pessoas que deveriam ser consideradas cidadãos com direitos e deveres, ainda que portadoras de alguma necessidade especial; e por necessidade especial refiro-me a todo e qualquer tipo de demanda que exija toda e qualquer forma de ação inclusiva em um dado cenário. A partir de 1948, com a 
Declaração Universal dos Direitos Humanos, surgiram as primeiras críticas sobre a segregação. Daí, os movimentos em prol da inclusão, que implicava e pleiteava o envolvimento de toda a comunidade mundial para que houvesse a inclusão de todos, em todas as partes; esse processo deveria ocorrer sem importar se a inclusão fosse necessária por razões linguísticas, cognitivas, étnicas, socioeconômicas, entre outras, e que se desse por meio de uma política moralmente ética e concreta, e que contemplasse a diversidade social (GUEBERT, 2012).

Entendeu-se que os princípios que devem reger qualquer sociedade que se autodenomina inclusiva incluem o direito de igualdade sem discriminação, respeitando as possibilidades de todos sem importar sua condição física, intelectual, social, étnica, linguística, etc., para que, dessa maneira, os incluídos fossem autônomos, independentes e iguais. Entretanto, lamentavelmente, com a universalização do saber, não têm sido levada em conta as diversidades culturais, sociais, epistemológicas, individuais e coletivas. Ademais, os sistemas socioeconômicos vigentes agem de modo excludente ao privilegiar algumas minorias e marginalizar massivamente outras classes. Sendo assim, salienta Guebert (2012) que o processo inclusivo apenas será viável se balizado no tripé: vontade e consciência política, profissionais qualificados e envolvimento da sociedade civil.

Portanto, diante do exposto, ressalto que minha pesquisa com os imigrantes bolivianos em São Paulo é fundamentada no paradigma da inclusão, nos direitos humanos e nas articulações entre o direito à igualdade e à diferença, que devem abrir caminho para uma transformação verdadeiramente social. Tal ação deve lograr romper com uma trajetória de exclusão e segregação na sociedade local, embora eu esteja ciente de que há muitas barreiras e atitudes que impedem a plena participação dos imigrantes bolivianos na comunidade local em igualdade de oportunidades, ainda que contribuíssem para maximizar seu desenvolvimento social e, em consequência, beneficiariam a comunidade local como um todo. O mote das crianças da tribo Ubuntu aplicar-se-ia com toda a força nesse sentido e cenário. 


\subsubsection{Mote Filosófico}

Meu objetivo nesta divisa é considerar como a filosofia contribui para o entendimento do construto inclusão. Para tanto tratarei da concepção e das influências da visão ontológica aristotélica e heideggeriana em um primeiro momento para, em seguida, entendermos a acepção da não-identidade que esconde a vontade dos dominantes em Adorno e Horkheimer (1985; 2009). Concluirei com as considerações sobre inclusão social de Habermas (2002).

\section{"[...] e num destes abismos vêm precipitar-se todas as ontologias."}

- Alexandre Herculano

Vejo como apropriado e oportuno abordar a questão imigração inclusiva por um olhar ontológico e filosófico, assumindo que pode aplicar-se ao ser humano enquanto imigrante, ou seja, nossa natureza é comum e inerente a todos de forma singular, concreta, individual e coletiva. Entendê-lo assim resulta em implicações diretas sobre as questões identitárias e de inclusão sóciocultural, pois somos seres sociais e sociáveis embora fundados em identidades próprias e que são, ao mesmo tempo, compartilhadas coletivamente.

Tanto Aristóteles como Heidegger concebiam o ser humano de forma pragmática e empírica, pois ambos se preocupavam com o que angustiava o ser humano, e eles se interessavam pela busca de condições que propiciassem bem-estar, o desfrute das benesses dos avanços tecnológicos e, em última instância, a felicidade. Não coadunavam com o conceito platônico, que concebia o sofrimento como necessário e aceitável, mas, antes, que temos a capacidade de pensar de forma inteligente, de nos organizar socialmente de modo a estar inevitavelmente interconectados, e a produzir conhecimento capaz de (trans)mudar algo primariamente potencial em algo concreto, real e palpável, visto que não somos, ressalto, seres isolados, visto que somos unidos por interesses comuns.

Ao centrar-me um pouco mais em Heidegger, destaco que ele liquida o sujeito cartesiano de Descartes e alerta que as pessoas perdem contato com sua individualidade ao serem influenciadas pelo comportamento das massas, pela preocupação com o consumismo, vendo assim totalmente comprometidas sua identidade. Sua postura filosófica encontra eco no universo do imigrante que busca uma vida melhor, embora, em seu processo migratório, 
muitas vezes, se confronte com tormento, hostilidade, desafio e dor que geram profunda desilusão, dada à diversidade cultural e linguística com que se confronta.

Entendo haver estreita relação entre os conceitos e a visão ontológica aristotélica e heideggeriana e a questão identitária e de inclusão social dos imigrantes bolivianos, porquanto, embora o ser humano tenha características individuais próprias, somos seres sociais e nosso anseio é viver em condições de equidade e justiça. Olhar a imigração pelo viés ontológico ajuda a entender quão distante está o trato dispensado ao imigrantes bolivianos e como acaba por massacrar a identidade individual e coletiva, o que é claramente contrário ao proposto e ansiado pelos dois filósofos em pauta.

Em Theodor Adorno e Max Horkheimer, da Escola de Frankfurt, é oportuno compreender o tema da não-identidade dos imigrantes bolivianos velada pelos dominantes. Estou ciente de que a inclusão desses dois filósofos no bojo deste texto soa, no mínimo, fora de enquadro e estranha para o leitor desta dissertação. Explico-me.

Lamentavelmente, atrevo-me a afirmar que o conceito de massas, de Karl Marx, foi apropriado e tergiversado pela classe dominante em nossa sociedade atual [e desde sempre]. Inicialmente, e contribuinte a esta dissertação, destaco em Adorno o fato de que havia rompido com o conceito marxista em favor da cessão de voz e valor ao pensamento crítico, reflexivo e individual em oposição à difusão e massificação do consumo [de símbolos; sistemas simbólicos], conforme considerei em Bourdieu na subseção anterior. As razões que o levaram a tal rompimento foram as convulsões do período em que viveu: revolução russa, duas guerras mundiais, campos de concentração e extermínio, regimes ditatoriais, etc., que o fizeram refletir sobre o impacto da massificação na transmissão de bens e valores, o modo como a sociedade ocidental havia destruído o potencial emancipador do indivíduo e como a manipulação das massas mediante o estabelecimento crescente de uma indústria da cultura dificultava todo pensamento crítico tanto no âmbito individual como coletivo, social.

Adorno e Horkheimer (1985) discorrem sobre o processo de regressão do esclarecimento a uma ideologia dominante, mediante a mistificação das massas e conversão das pessoas em objeto de dominação e, assim, criticam a condição duma sociedade supostamente esclarecida, ressaltando, portanto, que: 
No sentido mais amplo do progresso do pensamento, o esclarecimento tem perseguido sempre o objetivo de livrar os homens do medo e de investi-los na posição de senhores. Mas a terra totalmente esclarecida resplandece sob o signo de uma calamidade triunfal (ADORNO; HORKHEIMER, 1985, p. 19).

Para os autores, a sociedade que se auto-nomeia como esclarecida não passa de uma sociedade administrada, dominada e cujos indivíduos, incluindo os imigrantes, se vêem completamente anulados em face do poder econômico, da visão utilitária e da racionalidade técnico-instrumental, que impinge à sociedade a sua condição de alienação e absoluto enclausuramento.

Na sequência, entendo que Adorno (2009) pode aportar a esta dissertação sua visão alertadora da racionalidade moderna que é eminentemente instrumental, técnica, científica e nos mecanismos de organização social, ou seja, usa[va]-se a razão para atingir este ou aquele fim. Tal ação ou postura social possibilitou que sistemas opressivos que [ir]racionalmente usa[ra]m esses meios instrumentais conseguissem o poder, o controle, o domínio e a manipulação da consciência da sociedade.

Ao discorrer sobre a relação binária entre identidade e não-identidade no âmbito filosófico e social, Adorno o faz com propriedade, pois, em suas palavras::

[...] seu propósito primeiro é desobstruir com intransigência a densa camada ideológica que oculta as contradições do social e iluminar o duro chão da realidade, pois a partir do momento em que a filosofia rompeu sua promessa de ser idêntica com a realidade ou de estar prestes a efetivá-la, está obrigada a auto-criticar-se sem piedade (p. 11);

O mais mínimo resto de não-identidade era suficiente para desmentir a identidade, totalmente segundo o seu conceito. As excrescências dos sistemas desde a glândula pineal de Descartes e os axiomas e definições de Spinoza, nos quais já está injetado todo o racionalismo que ele extrai posteriormente de maneira dedutiva, manifestam por meio de sua nãoverdade a não-verdade dos próprios sistemas, sua loucura (p. 27);

Uma tal não-identidade não é nenhuma ideia, mas algo encoberto. O sujeito da experiência trabalha em seu desaparecimento. A verdade seria o ocaso do sujeito. Esse ocaso não é senão simulado pela subtração no método científico de tudo aquilo que há de específico para a subjetividade, ad maiorem gloriam do sujeito objetivado e transformado em método (ADORNO, 2009, p. 162). 
Em linhas gerais, Adorno destaca que a densa camada ideológica e dominadora consegue fazer com que o ator social, o imigrante em pauta, tenha sua real identidade omitida, ofuscada, desmentida pela não-identidade promovida e velada pela vontade do dominador.

Ao rematar e aplicar os conceitos de Adorno e Horkheimer abordados acima, entendo que a massificação de ações e o uso instrumental da razão desfavorece o imigrante, visto que o tolhe da capacidade de pensamento crítico, da manifestação de seu pleno potencial emancipador enquanto indivíduo social, de sua identidade cultural e nacional própria que acaba por velar a falácia da subjetividade constitutiva que só esconde a vontade de uma burguesia dominante em seu novo país que faz a promessa, amplamente propalada, de felicidade inequívoca. Assim, esse imigrante, destituído de sua identidade primeira, é envolvido numa teia de burocracia e tecnocracia em prol da aparência de prazer ante o meio social em que busca se inserir.

Assim, como no caso de Adorno e Horkheimer, mencionados anteriormente neste texto, incluir considerações ideológicas subjacentes à inclusão social a partir do pensamento de Jürgen Habermas parece uma contraposição no teor desta dissertação. No entanto, o que tenciono é apresentar de modo breve o conceito desse autor e como ele se relaciona com a situação dos imigrantes. Reconheço que, sendo Habermas um filósofo universalista, seu pensamento é pouco acessível e eclético, pois, por causa da sua ampla intertextualidade, ele aproxima pensamentos muitos distintos como, por exemplo, a filosofia analítica, a hermenêutica, a dialética e as teorias sociológicas, suprimindo fronteiras e não se fixando rigidamente em uma única linha teórica.

O que me interessa dos escritos e do pensamento de Habermas (2002) que creio ser oportuno incluir nessa consideração, refere-se inicialmente ao seu conceito de coisificação do ser humano, ou seja, na sociedade capitalista moderna, tudo vira produto de mercado, de consumo e isso se aplica, com bastante força, ao imigrante boliviano quando chega a São Paulo. Não é visto além de um produto que deve ter seus préstimos consumidos pela classe dominante, sem importar sua história, origem, identidade, interesses, etc. Para Habermas, a categoria trabalho, central na concepção marxista, não é suficiente para a emancipação. É necessária a integração social e cultural, etc., para que o imigrante alcance a emancipação em sua nova terra. Entretanto, isso não é possível e há exclusão, pois: 
A característica bifronte das nações, que se abrem para dento e se fecham para fora, já deixa nítido o significado ambivalente do conceito de liberdade. A liberdade particulariza de um coletivo que afirma sua independência nacional diante do exterior [do imigrante] (HABERMAS, 2002, p. 150).

Ampliando esse processo de exclusão de dentro para fora, Habermas fala do mundo da vida, vivenciado no cotidiano, e do mundo do sistema, da mecanicidade capitalista. Para ele, o primeiro está sendo colonizado e patologicamente reacoplado pelo segundo, ou seja, as pessoas estão sendo contaminadas, colonizadas pelos valores do trabalho; invadem o que não é de seu pertencimento, tornando-se capitalistas, competitivas e excludentes; impondo, desse modo, impermeáveis barreiras de exclusão social e cosmopolita.

Tal condição social, ideologicamente desenhada e mantida pela classe dominante mantém os desfavorecidos, imigrantes, em situação de absoluto abandono e violência social.

\subsubsection{Axioma Sociológico}

A proposta de inclusão social deveria conjugar igualdade e diferença como valores indissociáveis, avançando em relação à ideia de equidade formal. Para tanto, é necessário contextualizar as circunstâncias históricas da produção da exclusão na sociedade local e confrontar práticas discriminatórias, criando alternativas para superação da lógica da exclusão através de uma mudança estrutural nevrálgica na comunidade local. Entendo assim, pois o acesso aos espaços sociais não deve ser privilégio de um grupo dentro de padrões homogeneizados apenas; o paradoxo inclusão/exclusão deve ser rompido por meio da identificação de mecanismos e processos de hierarquização que operam na regulação, produção e manutenção das desigualdades no âmbito social, cultural e linguístico, entre outros, e que afetam a quase totalidade dos imigrantes bolivianos neste bairro paulistano. Acrescento, como razão de minha inquietação, meu entendimento de que qualquer tipo de discriminação, contra qualquer pessoa, em qualquer circunstância, configura violação da dignidade e do valor que deveriam ser inerentes ao ser humano, em especial, se são evidentes formas múltiplas e agravadas de discriminação por causa de raça, língua, origem étnica e social, diferenças culturais, ou qualquer outra condição que haja.

É fato que, nas pesquisas das ciências humanas e sociais que abarcam estudos nas áreas de sociologia, ciência política, direitos humanos, direito, psicologia social, educação e 
linguística entre outros, muito se tem falado do paradoxo inclusão/exclusão social, pois entende-se que se trata de um problema social que implica entender, para modificar, a visão que a sociedade moderna tem deles, pois operam entre os paradigmas do monopólio e dominação de classes minoritárias, ou majoritárias menos esclarecidas. É bastante latente e observável a relação que há entre aqueles que são socialmente incluídos por estarem apartados, isolados e protegidos contra a pobreza e a miséria que são, tristemente, sinônimos de desigualdade e vulnerabilidade social.

Assim, a inclusão social deve ser entendida como igualdade para todos, pois inclui acesso aos bens e serviços necessários para o pleno exercício da cidadania e para a manutenção da vida em seu aspecto físico e mental, primando pela dignidade e pelo valor do ser humano. A pesquisadora social Ermínia Maricato, numa declaração intrigante sobre uma possível definição do paradoxo em pauta, afirma em um de seus relevantes textos:

Não há como definir um limite preciso entre o incluído e o excluído. Não se trata de um conceito mensurável, mas de uma situação complexa que envolve a informalidade, a irregularidade, a ilegalidade, a pobreza, a baixa escolaridade, o oficioso, a raça, o sexo, a origem e, principalmente, a falta de voz (MARICATO, 1994, p. 51).

Embora concorde com Maricato no que tange à complexidade da situação dos imigrantes bolivianos em São Paulo pelas razões que ela apresenta, sobretudo no que diz respeito à situação [documental] irregular/ilegal, à pobreza e à falta de voz, entendo que podemos estabelecer limites entre o incluído e o excluído, conforme já salientei neste texto. Trata-se, então, de um problema não apenas de cunho comunitário local, mas de um problema de ordem política na busca de ações afirmativas em prol dos imigrantes.

Declara Giuliana Leal, ao apresentar o pensamento idealizado por Hanna Arendt:

$\mathrm{Na}$ esfera da política das representações e dos relacionamentos com o outro, o processo de exclusão opera pela discriminação e pela estigmatização, até o limite do não reconhecimento da humanidade do outro (LEAL, 2011, p. 13).

A posição de Maricato (1994) deve ter abrangência mais ampla, já que, como salienta Leal (2011), aqueles que não conseguem ser contemplados por processos inclusivos sofrem privação material e são desqualificados como cidadãos que possuem desejos e interesses 
associados à sua identidade pessoal e coletiva, o que, em última instância, os leva à luta apenas pela sobrevivência diária, uma vez que são alijados de seus direitos à cidadania.

Adentrado então na relação entre cidadania e igualdade, convirjo com Marshall (1967) quando este diz que esta se refere à participação integral na comunidade e, em seguida, divide a questão do exercício da cidadania em três elementos, ou partes, acrescentando:

O elemento civil é composto dos direitos necessários à liberdade individual - liberdade de ir e vir, de imprensa, pensamento e fé, o direito à propriedade [...]. Por elemento político, se deve entender o direito de participar do exercício do poder político [...]. O elemento social se refere a tudo o que vai desde o direito a um mínimo de bem-estar econômico e segurança até o direito de participar, opor completo, na herança social e levar a vida de um ser civilizado de acordo com os padrões que prevalecem na sociedade (MARSHALL, 1967, p. 64).

No caso dos imigrantes bolivianos, importa-me a concepção de cidadania de Marshall no que diz respeito aos elementos civil e social com especial ênfase ao direito ir e vir, que, em muitos casos, lhes é tolhido em alguns espaços sociais na comunidade local. E aqui não estou falando de haver sinalização tácita e explícita que impede os imigrantes bolivianos de entrarem em certos espaços na comunidade, mas sim a privação simbólica, velada e que os torna invisíveis e, assim, impedidos de ir e vir livremente. O mesmo aplica-se ao bem-estar socioeconômico e a um padrão de vida civilizados, pois são submetidos a condições de moradia, trabalho, saúde e educação de péssima qualidade, como discuti anteriormente neste texto, além de serem segregados linguística e culturalmente.

Portanto, no que tange à cidadania, o problema, a meu ver, é muito mais sério e complexo do que se fosse operacionalizado através de algum tipo de privação legal que seria visível, historicamente situada e passível de reivindicação de mudanças. Trata-se da criação, operacionalização e manutenção de restrições sociais ideologicamente naturalizadas e materializadas na comunidade que se diz acolhedora, mas que mal consegue ser tolerante. Neste viés, Pedro Demo alerta para um tipo de suposta inclusão que se encaixa com o acima:

Contigentes populacionais cada vez maiores são lançados, expulsos e integrados na margem do sistema, não porque sejam supérfluos, mas porque precisam ser descartados. Não se pode ignorar a condição de confronto, a unidade de contrários. [...] A condição de pobreza dos $80 \%$ da população mundial não é indicativa de condição supérflua, mas de marginalização historicamente produzida. Os excluídos, reprimidos na margem, estão aí incluídos, fazem parte intrínseca da dinâmica contrária. Não há aí dualismo ou dicotomia estanque, mas dualidade dialética. (DEMO, 2003, p. 85). 
Para o pesquisador, acima mencionado, os imigrantes bolivianos estão na margem do sistema, ou melhor dizendo, são incluídos na margem, estão aí. Isto implica dizer que não há espaço para eles na sociedade moderna e que eles devem conformar-se com sua sorte. Alinhado ao pensamento acima, de Demo (2003), faço referência ao trabalho de uma equipe de pesquisadores sociais franceses, coordenada por Pierre Bourdieu, que resultou na obra $A$ Miséria do Mundo (1997). O objetivo do sociólogo e de sua equipe era entender como a miséria social é produzida e mantida a partir de pequenas ações que são/estão (in)conscientemente cristalizadas, às vezes antagonicamente, no cotidiano dos reprimidos na margem, [...] aí incluídos num dado tecido social. Em resumo, sua meta de pesquisa era: "[entender] os verdadeiros determinantes econômicos e sociais, os inumeráveis atentados contra a liberdade das pessoas, contra sua legítima aspiração à felicidade e à autorrealização (p.735)”. Nessa obra, Bourdieu também chama a atenção para a formação de estereótipos constituídos a partir de espaços conflituosos que geram a distribuição de espaços sociais local e hierarquicamente construídos dada a ausência de ações do Estado fundadas na justiça social e de cunho inclusivo. Mais uma vez, essa é exatamente minha hipótese quando observo a situação dos imigrantes bolivianos neste bairro paulistano; hipótese esta que pretendo corroborar ao apresentar os resultados da análise do corpora. Sofrem, ao meu ver, atentados contra [sua] liberdade, são estereotipados e têm acesso a espaços sociais privados e, pior ainda, sob a velada anuência e/ou omissão do Estado.

Uma das possíveis razões que talvez explique esse comportamento e subsequente ruptura de relações, da não-aceitação do outro, concentra-se sobretudo numa possível categorização do imigrante [boliviano] como o desconhecido e marcado pela condição de transitoriedade e ambivalência (SIMMEL, 1979). Tal comportamento, ruptura e decomposição propicia o surgimento de mecanismos que levam à desagregação do tecido social conducentes à desagregação moral e guetorização, além, certamente, da privação, ou apenas de uma concessão mínima, de direitos sociopolíticos que anulam seus poderes de representatividade e tiram dos imigrantes bolivianos a oportunidade de qualquer influência no rumos dos acontecimentos sociais que afetam profusamente a comunidade residente nesse bairro em São Paulo. 
Outro problema que identifico no caso dos imigrantes bolivianos é que não ocorre sequer sua integração à sociedade acolhedora. Pensar e falar em integração implica entender o que significa e, nesse sentido, concordo com a definição proposta por uma pesquisadora de um centro nacional de pesquisa científica francês, quando ela diz:

A integração evoca inicialmente uma operação matemática. É integral aquilo que não é objeto de nenhuma diminuição nem restrição. Reportado ao fenômeno migratório, o termo exprime uma dinâmica na qual cada elemento tem a sua relevância própria. A integração supõe interdependência estreita entre os membros de uma sociedade em intercâmbio. A integração visa a uma filosofia política da cidadania (COSTA-LACROUX, 1992, p. 68).

Supor interdependência estreita entre os membros de uma sociedade em intercâmbio é o que justifica meu argumento de que os imigrantes bolivianos não são integrados na sociedade local. Não há relação estreita e, menos ainda, intercâmbio com as práticas e os espaços de convivência na sociedade local. Convergindo com Leal, é minha percepção que:

[...] a sociedade é formada por grupos e classes sociais com interesses distintos e, por vezes, opostos e contraditórios, o que inviabiliza pensar seriamente na presença de um interesse comum ou projeto válido, aceito e legitimado pelo conjunto da sociedade (LEAL, 2011, p. 61).

Portanto, partindo de um plano macro para um de natureza microssocial, tal formação social conjunta, ainda que dialética, deveria contemplar os imigrantes bolivianos, pois aspiram ser parte do coletivo, ou conjunto da sociedade local, com interesses distintos, às vezes não harmônicos e conflituosos, mas que almejam tornar parte da tessitura social local. Entretanto, dada a não integração, num primeiro momento, e a não inclusão a posteriori, qualquer ação nessa direção torna-se mais complexa e conduz à marginalização das diferenças explicada, sobretudo, pela falta de informação sobre os aspectos culturais e sócio-linguísticos.

Seguindo essa mesma linha de raciocínio, faço referência ao senador e educador Cristovam Buarque quando afirma que a complexidade do processo de integração visando a inclusão, gera desigualdade pela dessemelhança com o outro, apartando-o socialmente (BUARQUE, 1990). Para ele, incluir implica romper o círculo de apartação social, i.e. segregação em função da posição socioeconômica, ou outra qualquer. Para tanto, deve-se reconhecer que todas as pessoas, inclusive os imigrantes bolivianos, compõem a humanidade 
que compartilha características e direitos fundamentais. Buarque alerta ainda, não apenas para a aceitação das diferenças, mas, antes, reforça o fim das desigualdades:

Fazendo-se as pessoas [apenas] diferentes, e não desiguais, tornam-se legítimos os diques que isolam os pobres, formando o Gulag. Protegidos pela camuflagem ética, alguns podem defender seus privilégios e sua liberdade, como antes faziam os gregos (BUARQUE, 1999, p. 31).

Congruente com essa noção de apartação, ou perda do pertencimento social, Hanna Arendt (1999), ao analisar o processo de despersonalização, menciona, em uma de suas obras que a inclusão ocorre quando não há a eliminação da pessoa moral e de sua identidade por meio da perda de vínculos socioafetivos. No caso dos imigrantes bolivianos, postulo que, ao desembarcar e navegar por terras paulistanas, sofrem com esse processo de apartação social e despersonalização moral-identitária, o que resulta em seu desenraizamento sociocultural. Passam, assim, a estar como que num limbo, um entre-lugar, no tecido social que afeta radicalmente sua psique e seu modo de ser/estar, não somente em relação à sociedade paulistana, mas também no que diz respeito às suas relações familiares e com seus pares que passam a ser esparsas e afetadas por visões estigmatizadas isolantes.

Diante desse cenário, a inclusão ocorrerá apenas se tais imigrantes bolivianos puderem ser reconhecidos como tendo direitos legitimamente iguais aos que gozam os paulistanos, ou seja, que suas diferenças sejam aceitas e não apenas toleradas. Ademais, devem ser dotados de condições mínimas de vida, isentos de qualquer tipo de estigmas, estereótipos e preconceitos. Por fim, precisam receber o reconhecimento, inicialmente e sobretudo do Estado, como iguais. Em síntese, a tais imigrantes deve ser assegurado o direito a ter direitos.

De igual relevância é o alerta de Elimar Nascimento, ao considerar que a não inclusão social pode representar uma ameaça à paz social e à modernidade, pois a sociedade é desconfigurada e perde-se o conceito de solidariedade e universalidade de direitos (NASCIMENTO, 1998).

Leal (2011, p. 109) aponta para outro problema relacionado à questão da apartação e ameaça à paz social quando diz que "os apartados são desnecessários economicamente, sua presença é incômoda socialmente e sua atuação é portadora de risco político". Ou seja, os imigrantes bolivianos em tela passam a ser considerados assim pelos da comunidade local, pois passam a ocupar um espaço econômica e socialmente (i)legítimo. Para Cristovam 
Buarque, tudo isso contribui para que haja desordem, ilegalidade, caos e distúrbio. Para ele, “as massas excluídas passam a agir fora do sistema legal, já que não participam do sistema econômico [e de outros], gerando sujeira, degradação urbana e desarticulação social” (p. 80).

Para arrematar cito como digna de nota uma pesquisa de caráter quantitativo, realizada pelo Instituto de Pesquisas Econômica Aplicada, IPEA, e publicada em 2005. Nesse estudo, os pesquisadores destacam a situação presente e futura dos apartados socialmente, incluídos aqui os imigrantes bolivianos; para os pesquisadores do órgão, a inclusão só é possível se o indivíduo não é "limitado em sua possibilidade de ascensão social presente ou tenha artificialmente reduzida a possibilidade de ascensão futura” (IPEA, 2005, p. 87).

\section{Quadro 4 - Coligindo a inclusão (des)mascarada}

Falei de inclusão nesta parte, considerando os construtos estereótipo,

Guebert, 2012 preconceito, discriminação e diversidade que se entrelaçam e resultam

Semprini, 1999 em ações e práticas excludentes como as que sofrem os imigrantes bolivianos na cidade de São Paulo.

Tratei do apagamento da identidade sofrida pelos imigrantes bolivianos

Adorno, 2009 envoltos na densa camada ideológica e dominadora na sociedade local.

Habermas, 2002 Camada essa que exclui, pois está contaminada pela competitiva e implacável mecanicidade do sistema capitalista moderno.

Citei pesquisadores sociais ao chamar a atenção para a concepção de

Leal, 2011 cidadania, manutenção de ações antagonicamente cristalizadas que

Arendt, 1999

Buarque, 1990 produzem marginalização, miséria, guetorização, apartação social e despersonalização moral-identitária dos imigrantes bolivianos na metrópole paulistana. 
Em conclusão e finalizando a ideia de inclusão dos imigrantes bolivianos na sociedade paulistana, faço referência ao trabalho de Sposati (1999), que apresenta os aspectos necessários à inclusão, a saber, autonomia, qualidade de vida, desenvolvimento humano e equidade. Aspectos a que, lamentavelmente, os imigrantes bolivianos não têm acesso. Assim, entendo eu, são invisibilizados, apartados, guetorizados, segregados e privados da noção mais básica de humanidade; exatamente o oposto da divisa das crianças da tribo africana Ubuntu.

\section{Os (in)visíveis}

Rubens Lacerda de Sá ${ }^{12}$

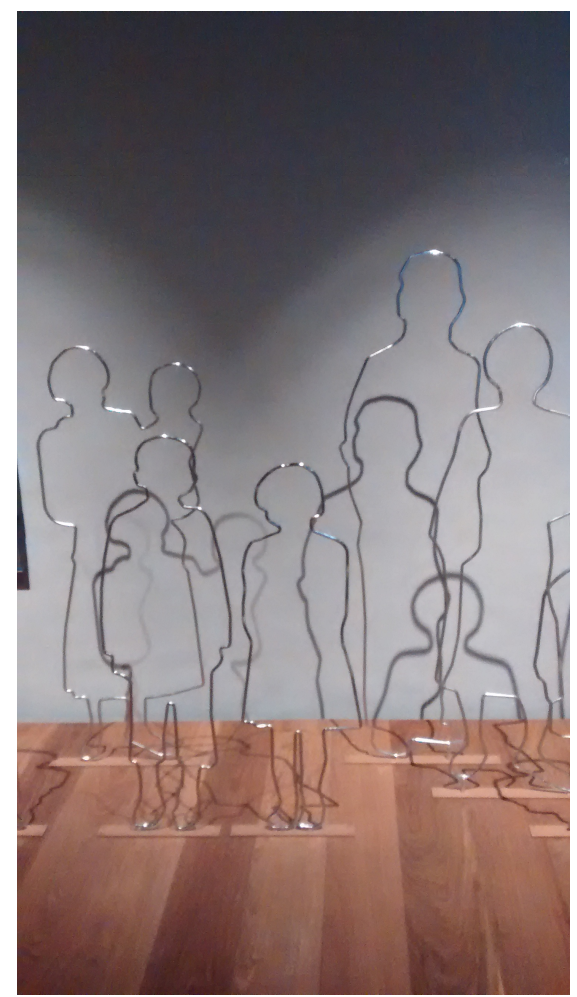

\section{3. Âncora (iii) | Identidades em (des)construção}

Figura 3 - (Des)construção identitária

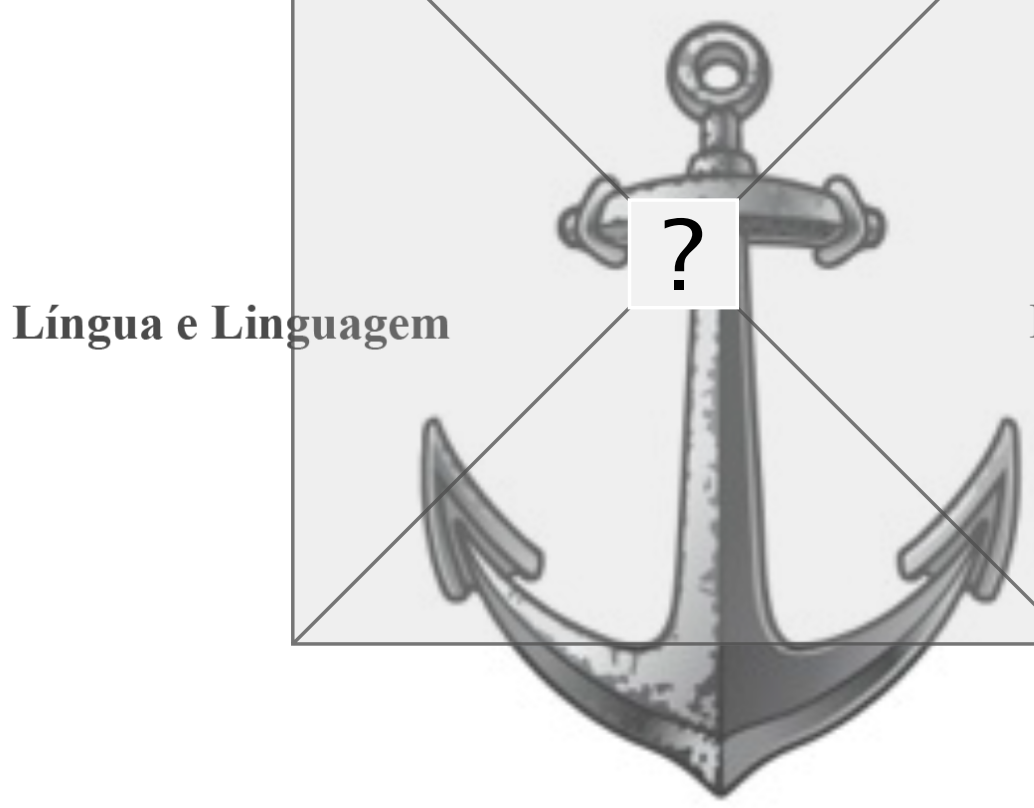

Políticas Linguísticas

Teorias Linguísticas Críticas

12 Essa foto retrata a condição dos imigrantes bolivianos em São Paulo. Existem, são visíveis, mas são invisibilizados na cidade. Foto tirada na 20 a Festa do Imigrante, 14-21/06/2015. Museu do Imigrante, São Paulo. 
Fontes: Figura elaborada pelo autor (2015)

Âncora: Google ${ }^{13}$

"Não quero a beleza, quero a identidade."

- Clarice Lispector

Neste ponto da dissertação procurarei, a partir de uma perspectiva sociossemiótica, construir e interpretar significados identitários no contexto social em que estão inseridos os imigrantes bolivianos na capital paulista. Embora entenda que a língua não funcione como reflexo passivo da realidade material, mas como participante ativo na constituição dessa realidade, procurarei entender a questão da (des)construção de identidades dos imigrantes bolivianos no cenário em tela fundada no tripé: língua e linguagem, políticas linguísticas e teorias linguísticas críticas.

Mas, antes de começar, leitor amigo, leia estes fragmentos dos versos de uma música.

"Eu me chamo de excluído como alguém me chamou,

Mas pode me chamar do que quiser seu dotô,

Eu não tenho nome,

Eu não tenho identidade [...]

Tenho que me alimentar,

Eu posso num ter nome mas o estômago tá lá, [...]

Eu sou sujo eu sou feio eu sou anti-social,

Não posso aparecer na foto do cartão postal.

Frustração,

É o resumo do meu ser [...]

Eu não sou civilizado,

Eu não sou computado,

Eu não sou consultado,

Eu não sou vacinado, $[\ldots]$

Eu não sou considerado,

Eu não sou respeitado, [...]

${ }^{13}$ Disponível: http://seapunk.com.br/camiseta-seapunk-ancora.html. Acessado em 20/04/2015 
Eu não sou representado por ninguém, Eu não sou apresentado pra ninguém $[\ldots]$ Além da minha triste sobrevivência, eu tento entender a razão da minha existência!"

O Resto do Mundo — Gabriel, O Pensador.

Os versos epigrafados da letra da música de Gabriel, O Pensador refletem a situação de vida de alguns - numa cifra sempre crescente - que pertencem, ou pelo menos estão, (n)a sociedade brasileira nos dias atuais e a realidade social que, insidiosa e silenciosamente, se faz (in)visível no cotidiano de nossas cidades; são anônimos, excluídos, invisibilizados, esquecidos e com identidade(s) expurgadas por sua situação social. Atrevo-me a aplicar os versos acima, fragmentos da letra da música, para introduzir esse tema: identidades em (des)construção, referindo-me aos imigrantes bolivianos que residem no bairro paulistano do Bom Retiro. Confesso-lhe, leitor amigo, que tentei destacar palavras e frases que creio representarem a situação de tais imigrantes no contexto mencionado, mas, para minha surpresa, choque e frustração, acabei dando-me conta de que todo o conteúdo, por mais triste, trágico e dramático que seja, pode ser aplicado aos imigrantes bolivianos neste bairro. Seguindo com essa introdução musical, lembrei-me também de outra música que, num tom mais positivo, reflete o que seria considerada uma situação desejável, verdadeiramente inclusiva.

"Sem horas e sem dores, Que nesse momento que cada um se encontra aqui e agora, Um possa se encontrar no outro, E o outro no um ... Até porque, tem horas que a gente se pergunta: Por que é que não se junta Tudo numa coisa só?" Sintaxe à Vontade — O Teatro Mágico. 
Ecoa em minha mente a indagação, a inquietação do grupo O Teatro Mágico: Por que é que, sem horas e sem dores, um não se encontra no outro e o outro no um [e] não se junta tudo numa coisa só? Quando penso na situação dos imigrantes bolivianos, fico pensando o porquê de as ações, ou ausência delas, do Estado e da comunidade local não propiciam a inclusão de tais imigrantes e a suave composição de uma identidade (bi)nacional, sem o expurgo da primeira em favor da segunda que se crê superior, melhor, mais civilizada.

Portanto, a todos os que navegam comigo neste texto, refaço o convite do poema $F_{O z}$ do Douro que epigrafou o capítulo 1 desta dissertação: Façamo-nos [outra vez] ao mar!

\subsubsection{Língua e Linguagem}

Sausurre conceituava a linguagem como processo individual ao passo que a linguística, pensada por um viés crítico, concebe linguagem como fato social. Mateus (2013, p. 93) fala de "linguagem [como sendo] atividade e consciência como elementos inalienáveis da/na existência humana [...] determinada pelas relações sociais”. E, prossegue:

\footnotetext{
Então, à luz dos estudos de Vygotsky, defino linguagem como o mais importante dos artefatos, produzido pela cultura humana e que, ao mesmo tempo em que é utilizado na comunicação entre homens e mulheres, forja as consciências daqueles envolvidos nesses processos de (re)produção. [...] reflete o mundo aponta[ndo] para uma realidade que lhe é externa, [...] pronta, mas também o refrata, quer dizer produz efeitos de sentido [...] com base nas experiências sócio-histórico-culturais da humanidade (MATEUS, 2013, p. 94).
}

Sendo como tal, na concepção sausurriana e de Mateus (op. cit.), há que se levar inevitavelmente em conta as relações de poder fundadas nas ideologias vigentes e que se relacionam como a situação dos imigrantes bolivianos, conforme já considerei neste texto. Portanto, por ser a linguagem uma prática social e de natureza ideológica, entendo que se deve incluir em sua análise a percepção de como operam tais ideologias, como são legitimadas e naturalizadas. Dentro dessa perspectiva ideológica (ADORNO, 2006), alguns pesquisadores da linguagem têm alertado para a luta pela busca de poder:

Não obstante, o que se observa hoje é a reconfiguração da postura mantenedora das diferenças numa roupagem aparentemente de luta e supostamente relacionada à busca da emancipação de um sujeito social (SOUTO-MAIOR, 2013, p. 252). 
Ampliando esse posicionamento, Fairclough (1992) destaca que a linguagem não é apenas produto de uma prática social sendo, assim, passível de mudanças. Trata-se de sentidos que são naturalizados para perpetuar relações de poder, de dominação e de injustiça social; para serem mudados ou transformados, é necessária a desnaturalização das ideologias presentes na linguagem. Daí, a demanda por estudos linguísticos com um viés crítico, engajados em transformações sociais. Como bem sintetiza a professora Claudiana Alencar:

Trabalhar com atores sociais na prática discursiva do ato de pesquisa, trabalhar sobre as questões de identidade, discriminação e poder, no palco da linguagem em que os signos são construídos, é lutar para atingir um vir-aser-tranformador no terreno escorregadio da linguagem e do social; é fazer uso de uma pedagogia do oprimido, como quis Paulo Freire (ALENCAR, 2006, p. 58).

Conforme destaca a citação acima, investigar questões de identidade implica relacioná-la com uma meta clara de transformação, embora não seja esta uma tarefa fácil. $\mathrm{Na}$ concepção racionalista cartesiana, a pessoa detinha uma identidade única, imutável e inalterável, ou seja, ou era ou não era, ou zero ou um — totalmente binária e polarizada. A meu ver, esse conceito continua sendo uma marca de pensamento, pelo menos na comunidade local, no que diz respeito à identidade dos imigrantes bolivianos. Na contramão dessa postura, ecoamos o pensamento de Zygmunt Bauman (1999) quando aponta para a busca pela ordem como marca da modernidade, ou seja, há uma preocupação pela classificação, pelo enquadramento, pela certeza, pela normatização, pelo fim da ambivalência. Foucault (2001) também converge com Bauman nesse sentido, pois, em sua perspectiva, essa concepção contribuirá para a adoção de práticas sociais pautadas pela disciplinarização. Novamente, encontro eco nos pensadores mencionados quando analiso a situação dos imigrantes bolivianos que têm sua identidade neutralizada e são invisibilizados na comunidade, pois ela atua de forma a alocá-los nessa ordem binária e normatizada socialmente.

Embora compreenda que, na sociedade contemporânea, as identidades estão em um ciclo de construção e reconstrução quase permanente, no caso dos imigrantes bolivianos, salta-me aos olhos que este processo não ocorra de modo natural e sob o comando dos mesmos, mas, antes, lhes é imposto pela comunidade local que quer borrar, e até eliminar, qualquer traço de sua identidade primeira em favor duma considerada superior. Em se tratando dessa desconstrução das perspectivas identitárias, lemos em Stuart Hall: 
Um tipo diferente de mudança estrutural está transformando as sociedades modernas no final do século XX. Isto está fragmentando a paisagens culturais de classe, gênero, sexualidade, etnia, raça e nacionalidade [...] mudando nossas identidades pessoais [...]. Essa perda de sentido de si estável é chamado, algumas vezes, de deslocamento ou descentração do sujeito - constitui[ndo] uma crise de identidade para o indivíduo (HALL, 2005, p. 9).

Não entendo que, no caso dos imigrantes bolivianos, ocorra essa fragmentação e instabilidade, às vezes contraditórias, pois eles, ao imigrarem, apenas anseiam a aceitação da comunidade local como são. No entanto, são levados, não em um processo natural, como leio em Hall, Foucault, Bauman e outros, a abrir mão de sua cultura, tradição, língua e, consequentemente, identidade para receberem acesso a esse espaço social simbólico. O que quero dizer com processo natural, em outras palavras, é que, aos imigrantes bolivianos não é dada a oportunidade de participar desse jogo de identidades, líquido, movediço e imprevisível, em que eles mesmos atuem como agentes dessa (des)construção.

Derrida (1991b) apresenta o conceito de différance que diz respeito à força que diferencia elementos um do outro, abrigando oposições binárias, hierárquicas e relações de poder. Nesse jogo, na différance, as identidades são construídas por ações de poder e exclusão. Na perspectiva da diversidade e da diferença, a posição socialmente aceita seria a do respeito e da tolerância para com a diversidade e a diferença, mas não é isso o que acontece no caso dos imigrantes bolivianos, ou como alerta Kathryn Woodward (2000, p. 28): “a celebração da diferença pode levar a ignorar a natureza estrutural da opressão". Foucault acrescenta ainda que "o poder não se dá, não se troca nem se retoma, só existe em ação [...] é, acima de tudo, uma relação de força” (FOUCAULT, 1988, p. 175). E, no caso dos imigrantes bolivianos, essa relação de força é implacavelmente desigual dadas as condições materiais e imateriais em que se processa. Anthony Giddens, ao falar sobre a identidade, apresenta a ideia de narrativas pessoais:

[...] a identidade de pessoa não se encontra no comportamento nem — por mais importante que seja - na reação dos outros, mas na capacidade de manter em andamento uma narrativa particular. [...] a linha de desenvolvimento do eu é inteiramente referida - o único fio significativo de conexão é a trajetória da vida como tal (GIDDENS, 2002, p. 55, 78).

A proposta de Giddens parece-me bastante interessante, mas, novamente, não posso conectá-la ou concebe-la como sendo levada a cabo no cenário em que estão inseridos os 
imigrantes bolivianos, pois parece não haver, na comunidade local, respeito por suas experiências individuais, e/ou coletivas, bem como suas histórias de vida que são fundamentais para a construção de sua identidade (bi)nacional. Em outras palavras, as condições ideológicas, discursivas e sociais não ressoam o reconhecimento de uma identidade primeira, ou como o próprio Giddens reconhece, "as escolhas [não] estão abertas a todos" (2002, p. 80), ou seja, perpetua-se, cristaliza-se a relação dominador-dominado. Essa nova identidade (re)construída é o que se apresenta ao imigrante boliviano neste espaço.

Pensar em identidade implica, ademais, entender a noção de subjetividade (HALL, 2005), dado que a (des)construção de identidades se realiza de forma dialógica, algumas vezes, e dialética, em muitas outras. E, nesse continuum, situado hierárquica, geográfica e sociohistoricamente, é que ocorre a inclusão/exclusão dos atores envolvidos. Tal movimento é subjetivo, pois envolve pessoas num espaço simbólico em que são (des)constituídas na diferença, ou seja, aquele que reivindica uma postura identitária é porque sofreu, de certa forma, algum tipo de atentado contra sua identidade primeira.

Com a consolidação da modernidade com seu aumentado fluxo e trânsito entre diferentes povos e nações, a questão da identidade passou a assumir papel em termos de conflitos e tensões sociais que são resultantes dessa arena que abriga uma pluralidade de poder(es) que são estruturalmente deslocados com a mesma velocidade dos avanços contemporâneos em todos os campos. Acrescida a essa relação de poder está a nova ordem de consumo que ora se configura na sociedade moderna. Ruberval Ferreira, ao falar sobre o poder do consumo nesse processo, diz:

Na nova ordem, marcada inicialmente pela busca do múltiplo, do diferente, e, logo depois, pela busca desenfreada do consumo de bens materiais e simbólicos, a questão de identidade assume-se como elemento central [...] e quanto mais o indivíduo está inserido na arena do consumo, mais incluído socialmente ele se sente (FERREIRA, 2010, p. 32, 33).

Embora seja exatamente isso que ocorre no caso dos imigrantes bolivianos, também observamos que se trata, no caso deles, de buscar pontos de intersecção para homogeneizar a partir da nova identidade (bi)nacional; há, portanto, um movimento de auto-acomodação aos padrões da sociedade local num esforço para aceitação social.

Ampliando minhas reflexões sobre o caso dos imigrantes bolivianos em São Paulo, concebo a linguagem como sendo um artefato histórico e culturalmente produzido na/pela 
sociedade através de complexos sistemas de interação e práticas sociais, sejam essas situadas ou não. Lamentavelmente, é através da língua, como uma das manifestações da linguagem, que as muitas ideologias, como já abordei neste texto, que circulam num dado momento sócio-histórico, político e cultural servem de ferramentas para a perpetuação de um bem velado, (in)verossímil e parcial ou, principalmente, para a perpetração dum mal social, para a eliminação ou manutenção de desigualdades e injustiças sociais, que alcançam a todos na sociedade, mas, em especial, os imigrantes que estão num processo inicial de inclusão.

Meu entendimento é corroborado pelas práticas que observo serem levadas a cabo na sociedade paulistana em relação ao imigrantes bolivianos que aqui desembarcam. Impedidos de participação e interação social, numa acepção vygotskyana, são excluídos e têm sua identidade desconstruída e turvada pela língua(gem), no entorno social em que se inserem. Neste sentido, esse texto assume em diferentes momentos, conforme já observado pelo leitor amigo, um tom de denúncia contra as injustiças a que são submetidos os imigrantes bolivianos. Tal denúncia assumirá um tom mais acre à medida que apresento e analiso os dados coletados junto aos participantes que se voluntariaram para essa pesquisa.

\subsubsection{Políticas Linguísticas}

Em 1996, Spivak quis saber se o subalterno na sociedade contemporânea tinha voz, se podia falar. É triste dizer que, embora não dirigida ao caso dos imigrantes bolivianos, posso afirmar que, quando aplicamos sua inquietação a estes, a resposta resulta numa retumbante negativa, ou seja, na sociedade paulista, tais imigrantes são desprovidos de voz e espaços socialmente inclusivos e conducentes à preservação e ao respeito por sua identidade primeira. Pior ainda, são estereotipados e sofrem com o congelamento dessa identidade como parte de um movimento de poder hegemônico. Bhabha (1998) mostra que a estereotipação cotidiana nega a importância da diferença; esta negação, por sua vez, serve apenas aos interesses dos que, por meio do poder que detêm, aglutinam as identidades dos imigrantes bolivianos, despindo-os de orgulho da terra natal, da pachamama. Rajagopalan (2006) chama a atenção para o fato de que tal processo desumanizador está enraizado em questões de cunho político: 
Compreender a questão da identidade como algo do qual não podemos subtrair a dimensão política sob pena de descaracterizá-la [...] é dar um passo inicial em direção a uma abordagem de identidades como construtos, sendo constantemente revistos de acordo com interesses específicos do momento (RAJAGOPALAN, 2006, p. 76).

Portanto, a agência politicamente motivada na questão das identidades como construto varia de acordo com interesses específicos do momento. No caso dos imigrantes bolivianos, urge, no meu ponto de vista, que seja adotada na sociedade paulista uma agenda política propositiva para assegurar-lhes vez e voz nas esferas sociais em que transitam, sem que tenham sua identidade estereotipadamente congelada e fragmentada. Uma vez que esse processo de inclusão/exclusão e a (des)construção da identidade (bi)nacional dos imigrantes bolivianos, no contexto desta pesquisa, ocorre por meio da linguagem, mais especificamente pela língua dos atores implicados nesse cenário, convém destacar que o tema de identificação nesse movimento identitário passa a ser, em última instância, uma reivindicação linguística e política, como bem salienta e explica o professor Kanavillil Rajagopalan:

A identidade de um indivíduo se constrói na língua e através dela. Isso significa que o indivíduo não tem uma identidade fixa anterior e fora da língua. Além disso, [isso] depende do fato de a própria língua em si ser uma atividade em evolução e vice-versa. Em outras palavras, as identidades da língua e do indivíduo têm implicações mútuas. Isso por sua vez significa que as identidades em questão estão sempre num estado de fluxo (RAJAGOPALAN, 1998, p. 41, 42).

A acepção apresentada pelo Professor Rajagopalan vai contra a ideia de uma identidade pura, verdadeira e imutável, em especial no caso dos imigrantes bolivianos, pois estes encontram-se imbricados num turbilhão sócio-histórico, político e cultural que tende a modificar sua identidade primeira pela língua. O que entendo eu não ser admissível é que essa modificação ocorra de forma a anular suas marcas culturais e identitárias originais em favor de uma suposta aceitação social em seu novo contexto. Conforme denuncia e alerta Jacob Mey (1985, p. 16), “o nosso uso da língua [não pode] solidifica[r] os interesses dominantes de nossa sociedade, ajudando a oprimir um grande segmento da população".

Seguindo com minha consideração da relação linguística-políticas, amplifico o pensamento de Rajagopalan (2003) quando ele destaca que trabalhar com a linguagem implica necessariamente intervir na realidade social da qual ela faz parte. Linguagem e Linguística são, em outras palavras, uma prática social repleta de conotações 
ideológico-políticas que as acarretam, pois nossas falas e posturas sempre são atravessadas por tais conotações e não há como sair da linguagem para falar sobre ela de forma descompromissada.

Deste modo, no caso dos imigrantes bolivianos, a questão linguística está totalmente relacionada à questão política. Pensemos, por exemplo, num dos apertos que caracterizam a xenofobia a que são submetidos tais imigrantes nesse cenário. Prefiro nomear esse aspecto de xenolinguofobia, que parte da união dos vocábulos língua e xenofobia, ou seja, um tipo de atitude xenofóbica, anti-imigrantes, manifestada especificamente pelos usuários da língua do país que supostamente acolhe tais imigrantes numa acepção pragmática, pois tal evento ocorre na/pela língua em uso, ou seja, nas instituições locais, sejam estas públicas ou privadas, os imigrantes bolivianos são privados do direito de usar sua língua materna o que, em última instância, equivale a roubar-lhes a própria identidade. Neste respeito é oportuna a explanação do Professor Kanavillil Rajagopalan sobre o assunto:

[...] a língua é muito mais que um simples código ou instrumento de comunicação. Ela é, antes de qualquer outra coisa, uma das principais marcas da identidade de uma nação, um povo. Ela é uma bandeira política [...] A língua serviu, serve e sempre servirá como ponto de aglutinação de um povo (RAJAGOPALAN, 2003, p. 93, 94).

A declaração do Professor Rajagopalan encontra eco em alguns fotos históricos. Por exemplo, na Alemanha nazista com Adolf Hitler, na Itália fascista de Benito Mussolini, na Espanha sob a ditadura de Francisco Franco e, recentemente, na Croácia de Franjo Tudjman. Em todos os casos mencionados, os ditadores entendiam que a privação do uso da língua dos dominados contribuiria para que sua identidade fosse gradualmente substituída pela dos dominadores que se criam superiores política, cultural e socialmente. Portanto, embora de maneira mais velada, os imigrantes bolivianos, ao serem privados no contexto público do uso de sua língua materna estão, por assim dizer, sendo submetidos a um processo que pode levar, conscientemente ou não, à substituição, ainda que parcial, de suas marcas identitárias pelas as do país que os recebe.

Pensando no cenário mundial contemporâneo, lembrei-me de que George Orwell em seu romance Revolução dos Bichos, apresenta as personagens em que todos eram em princípio iguais, mas alguns eram, de fato, "mais iguais que os outros". A comunidade onde se 
inserem os imigrantes bolivianos neste bairro paulistano reproduz o lema da obra de Orwell, ou seja, somos todos iguais — inclusive os imigrantes bolivianos — mas, de fato, somos lá no fundo, uns mais iguais do que outros. E é nessa concepção (des)igual que residem os intentos de homogeneizá-los; e, esse processo gera mudança identitária profunda na/pela língua(gem). Não se lhes permite transitar nos espaços sociais com uma entre-língua, pois esta é conceituada em termos de tudo ou nada, há uma classificação categórica — ou são nativos da língua portuguesa ou são estrangeiros, leia-se estranhos e, portanto, impedidos, ainda que veladamente, de usar a língua numa categoria mista, embora o façam mesmo assim.

Essa postura, que prejudica bastante a manutenção identitária dos bolivianos, vai de encontro com a nova realidade geopolítica ocasionada pelas ondas migratórias em que o multilinguismo torna-se cada vez mais a norma e não a exceção; torna-se a língua franca no mundo moderno (DESAI, 1955). Neste cenário, o mundo perde-se em meio a identidades suscetíveis à renegociação e realinhamento para que sejam adaptadas e adequadas às novas circunstâncias que surgem. E mais, "as identidades coletivas são sempre definidas de forma negativa. Nós nos reconhecemos enquanto nós, pois somos diferentes deles" (HOBSBAWN, 1996, p. 40).

Refletindo um pouco mais sobre o tecido social moderno, nos rondam palavras como globalização, regionalização, transnacionalização, desterritorialização, volatilidade, instabilidade, rompimento de barreiras comerciais, econômicas, culturais e de restrições de livre circulação, era da informação, etc., ou seja, hoje somos o que sabemos e/ou o que produzimos. Isso, afeta a identidade da sociedade moderna e, mais ainda, dos imigrantes que se mudam a outro país, totalmente alheios ao seu. Assim, a língua(gem) está no epicentro desse abalo sísmico identitário que requer constante (des)construção e deve nos impedir que cultivemos um ideal quixotesco de que haverá uma acomodação natural e sem conflitos no caso de tais imigrantes. Pensar assim equivaleria à promoção de certo chauvinismo linguístico com bases imperialistas, pois, entendo eu que, os que não dominam à perfeição a língua do país que os recebe não podem, ou melhor dizendo, são impedidos, ainda que não intencionalmente, de ter acesso pleno a determinados bens e serviços disponíveis.

Entendo que qualquer tipo de expressão de imperialismo linguístico prejudica a sobrevivência de línguas minoritárias - e quando pensamos nos imigrantes bolivianos que se mudam para o Brasil, sua língua materna passa a ser minoritária e a estar sob a influência, o 
ataque e a pressão de ideologias estruturantes que reproduzem desigualdade de poderes, recursos e acessos. Seu devir social passa a ser condicionado a uma concepção baseada no equivocado, no meu ponto de vista, modelo chomskyano de um falante cognitiva e cartesianamente onipotente, e que ainda é, bastante impregnada em nossa sociedade. A competência na língua do país acolhedor, cujo falante nativo é o perfeito, passa a ser, não por escolha consciente, mas por coerção velada, o almejo central destes imigrantes bolivianos para que possam ser invariavelmente aceitos na sociedade local.

Tais imigrantes entendem, assim, que a língua e a cultura do país que os acolheu deve ser considerada, ainda que contra sua vontade (in)consciente, como superior, de mais valia. Assim, o próprio trânsito entre as duas e diferentes línguas implica a redefinição de sua própria identidade. Não ocorre em todo esse processo o que sugere Canagarajah (1999b), quando destaca que [os imigrantes bolivianos] devem aprender a relacionar-se com a língua Portuguesa de modo a minimizar sua influência e impacto sobre sua nova identidade, sem que esta os induza a negar por completo sua identidade anterior. Antes, propõe ele, ambas (línguas) devem contribuir para um diálogo profícuo e de aprimoramento, ainda que circunscritos num conflituoso turbilhão bi-cultural.

Portanto, concluo eu, urge a concepção e implementação de uma agenda política e linguística que atenda às demandas e necessidades dos que são privados do direito de escolha, composição e manutenção de sua identidade seja esta nacional ou binacional. No que tange às políticas linguísticas, não se trata, entendo eu, apenas da proposição de investigação de dado problema social, como o que tenho abordado no decorrer deste texto, mas, antes de mais nada, de que se elevando acima do nível teórico, propiciar ganhos reais e práticos no sentido de melhorar a qualidade da vida dos atores implicados no processo. Não se trata apenas de investigações diagnósticas e descritivas, antes porém deve(mos) o(s) pesquisador(es) da língua(gem) criticamente propor mudanças de cunho linguístico-político, visando ao benefício ad aequitas de todos os que dependem de tais estudos acadêmico-sociais. 


\subsubsection{Teorias Linguísticas Críticas}

Nos estudos da linguagem, há o que o Professor Kanavillil Rajagopalan chama de sacralização de determinados textos/teorias. Trata-se de um processo que nos cega, pois a leitura acrítica é desprovida de novos olhares, novas perspectivas. Entendo eu que não levar o pesquisador em conta o cenário social em que seu objeto de estudo está imbricado faz com que ele se posicione em suas divagações totalmente "alheio ao mundo prosaico da realidade que o cerca sendo a introspecção seu modus operandi e a solidão sua atmosfera autoimposta”, tal como retrata a escultura $O$ Pensador de Rodin (RAJAGOPALAN, 2010, p. 24).

A partir desse fio condutor, optei por trazer à baila duas teorias linguísticas de cunho crítico (FOWLER, 2004) para meu texto, visto que elas propiciarão seleção variada de categorias descritivas apropriadas ao mote central de minha pesquisa, e ao que emergirá a partir dos dados coletados, conforme amplio essa justificativa no capítulo que tratará minha metodologia de pesquisa. Entendo que essas teorias alinham-se ao conceito mais amplo de crítica conforme proposta pela Escola de Frankfurt:

'Crítica' [...] denota reflexão sobre um sistema de constrangimento produzido pelo homem: pressões deformadoras às quais os indivíduos, ou grupos de indivíduos, ou a raça humana como um todo, sucumbem em seus processos de formação pessoal. A abordagem crítica supõe que existe um certo grau de distorção já instalada que se apresenta como realidade [e] busca remover esta distorção e assim tornar possível a liberação do que foi distorcido (CONNERTON, 1976, p. 18, 20).

Como bem sintetiza a citação acima, a vertente crítica das teorias linguísticas está intimamente relacionada com representações na sociedade, ou seja, com um conjunto de práticas e valores sociais que se configuram na/pela língua(gem) e que, uma vez tendo sido moldadas, devem ser desafiadas, e reconfiguradas sem juízo de valores. Como bem destaca o autor acima, as distorções da realidade social devem ser identificadas e corrigidas. Neste sentido, as teorias linguísticas de cunho crítico têm objetivos similares aos da sociologia crítica cuja preocupação também se relaciona com a emancipação individual ou coletiva:

A crítica [...] objetiva a mudança ou até a remoção do que é considerado como consciência falsa ou distorcida [...] torna transparente o que previamente estava oculto, e, ao fazer isso, inicia um processo de reflexão destinado a romper com a dominação de limitações passadas. Aqui uma mudança na prática é, portanto, um elemento constitutivo de uma mudança na teoria (CONNERTON, 1976, p. 20). 
Assim, meu interesse em fazer uma análise linguística pelo viés crítico se dá para que eu possa, quiçá, desvelar representações falsas e discriminações em diferentes tipos de discurso em relação ao imigrantes bolivianos na cidade de São Paulo. Tais eventos sóciodiscursivos os impedem de serem plenamente incluídos na sociedade local, embora o sejam do ponto de vista político, por serem acolhidos no Brasil; ademais, a sua identidade de caráter (bi)nacional é bastante (des)construída no cenário e na conjuntura em que se encontram.

Estou ciente de que não há uma teoria de língua(gem) completa em si mesma nem totalmente satisfatória; daí a opção que faço de valer-me de, pelo menos, duas delas para identificar, descrever e analisar os diferentes fenômenos e seus contextos sociais, culturais, históricos, econômicos, linguísticos, etc. envolvendo os imigrantes bolivianos em São Paulo, qual escopo central desta pesquisa.

Pensando inicialmente que meu primeiro objeto de estudo nesta pesquisa se relaciona com a inclusão dos imigrantes bolivianos no contexto de uso de comunicação na/pela língua(gem), vejo o diálogo entre a abordagem crítica de ideologia de Thompson (2002a) e Análise de Discurso Crítica como bastante apropriado para ser inserido com uma das perspectivas teóricas críticas. Este diálogo servirá para ancorar a análise das narrativas escrita e visual dos participantes na pesquisa, que foram estimulados por fotos e um videoclipe ${ }^{14}$.

Usei um vídeo que retratava sua terra natal e incentivei os participantes a escrever e, em seguida, desenhar sobre como ocorreu o processo de inclusão na comunidade local. Portanto, a partir da abordagem crítica de ideologia de Thompson (2002a) e de alguns pressupostos da Análise de Discurso Crítica, pretendo entender como se processa a inclusão e a (in)visibilização dos imigrantes bolivianos em São Paulo.

Para fins de apropriabilidade, farei referência sempre a Análise de Discurso Crítica, como a teoria-mestre para a análise das histórias de vida dos participantes desta pesquisa. Entretanto, ressalto que incluo aqui o meu foco central na abordagem crítica de ideologia de Thompson (2002a). Justifico a razão da escolha dessa abordagem conjunta para esse recorte de meu corpora, baseando-me nas asserções de um de seus teóricos, quando ele destaca que:

\footnotetext{
14 Pretendo, ao usar essa abordagem conjunta, responder as perguntas dois e três de minhas hipóteses de pesquisa: a) Assumindo que há desníveis e disparidades marcadamente ideológicos, excludentes e discriminatórios, no trato com os imigrantes bolivianos, que atitudes são reveladas por suas escolhas linguísticas ao falar da questão da inclusão e (in)visibilidade? b) Como as histórias de vida, dos assim (in)visibilizados imigrantes bolivianos em tela, revelam a profundidade das questões de inclusão em âmbito local?
} 
[...] os estudos de discurso devem ser críticos quando: as relações de dominação são estudadas principalmente na perspectiva do grupo dominado e do seu interesse; as experiências dos (membros de) grupos dominados são também usadas como evidências para avaliar o discurso dominante; pode ser mostrado que as ações discursivas do grupo dominante são ilegítimas; e, podem ser formuladas alternativas viáveis aos discursos dominantes que são compatíveis com os interesses dos dominados (van DIJK, 2015, p. 15).

Assumo que, para a Análise de Discurso Crítica, a linguagem como um dos estratos do mundo real, conforme anteriormente discutido, possui mecanismos de geração de poder com efeitos (im)previsíveis qual prática social, concebidos a partir de uma perspectiva lógica relacional-dialético-dialógica entre discurso e sociedade, na qual se inserem os atores sociais.

Por se tratar de uma prática social não se relaciona unicamente com indivíduos numa determinada teia social, mas com a dinâmica do coletivo, com a relação entre a teia social, seus agentes e suas entidades/instituições. Sendo de caráter inter e transdisciplinar, a Análise de Discurso Crítica, entende que a linguagem como prática social não é apenas constituída socialmente, mas também constitui "identidades, relações sociais e sistemas de conhecimento e crença" (FAIRCLOUGH, 1995, p. 131), e, por esse motivo, entende que "questões sociais são, em parte, questões sobre discurso" (CHOULIARAKI; FAIRCLOUGH, 1999, p. vii).

Como mentor da Análise de Discurso Crítica, Fairclough define seu objetivo:

Minha motivação em levantar essas questões é a crença de que textos têm conseqüências e efeitos sociais, políticos, cognitivos, morais e materiais, e de que é vital compreender esses efeitos se pretendemos levantar questões políticas e morais a respeito das sociedades contemporâneas [...]. Minha abordagem insere-se amplamente na tradição da 'ciência social crítica' - ciência social motivada pelo objetivo de prover base científica para um questionamento crítico da vida social em termos políticos e morais, ou seja, em termos de justiça social e poder (FAIRCLOUGH, 2003, p. 14).

Neste sentido, saliento que a Análise de Discurso Crítica se alinha à minha pesquisa, pois, sendo o discurso visto como central nas práticas sociais, almejo compreender o uso da linguagem envolvendo os imigrantes bolivianos em São Paulo nos diferentes níveis da vida social, desde as estruturas sociais aos eventos sociais e as práticas correspondentes. Sendo a vida diária fluida envolvendo pessoas, recursos materiais, inter(ação) e relações na/pela linguagem, pretendo analisar como os discursos que circulam na comunidade local 
contribuem para a inclusão dos imigrantes bolivianos e como tal influência é apresentada em suas narrativas de vida, escrita e visual. Entendo que a heterogeneidade e abertura inter e transdisciplinar da Análise de Discurso Crítica é fundamental para os objetivos desta pesquisa cujo recorte é linguístico e sociológico (ANDRADE et. al., 2008).

Atendo-me um pouco mais na questão do discurso, gostaria de salientar que eles são construídos e possuem efeito igualmente construtivo, pois estão atrelados às relações sociais, aos sistemas de crenças e à gestão de conhecimento. As narrativas de vida estão associadas à gestão de conhecimento, pois seu objetivo é relatar eventos com algum propósito útil. Isso faz com o que o discurso seja um processo complexo, pois, como salienta Fairclough (2003, p. 224), "[as pessoas] também são agentes que fazem, criam e mudam [as] coisas"; e, no caso, das narrativas de vida, estas descrevem uma série de eventos discursivos relacionados "lógica e cronologicamente" (FAIRCLOUGH, 2003, p. 83).

Entendo assim que, a partir das narrativas, tanto escritas como visuais, dos imigrantes bolivianos, poderei analisar os textos daí advindos como um evento discursivo ligado a determinadas práticas sociais locais. Tais textos, para a Análise de Discurso Crítica, são marcados por ações individuais e coletivas, relações (a)simétricas, crenças, valores, ideologias e marcas de poder — todos situados em um momento sócio-histórico específico. Pensando, no elencado anteriormente, entendo que as relações de poder identificáveis no textos mencionados podem ser mudadas e superadas para o benefício dos imigrantes em pauta. Já discuti em outro momento neste texto o conceito de poder como hegemonia, segundo os preceitos gramscianos (GRAMSCI, 1978; 1995).

Portanto, no bojo do processo de luta(s) hegemônica(s) no/pelo discurso que circula instauram-se, muitas vezes, um poder abusivo que beneficia uns em detrimento de outros e que é mantido através de representações ideológicas que acabam por resultar na "distribuição desigual de poder baseada no consenso" (RAMALHO; RESENDE, 2011, p. 24). Tais ideologias passam, assim, a funcionar como instrumento para a manutenção do poder de uns em relação a uma minoria social e/ou linguística. Essas ideologias são legitimadas, naturalizadas, invisibilizadas e reproduzidas, em larga escala, para que possam ser vistas/tidas como aceitáveis e possam sustentar as desigualdades que são perpetuadas pelo(s) discurso(s) que as carregam. Ao falar sobre ideologia(s) e os atores implicados, Fairclough diz: 
Os sujeitos são posicionados ideologicamente, mas também são capazes de agir criativamente no sentido de realizar suas próprias conexões entre diversas práticas ideológicas a que são expostos e de reestruturar as práticas e as estruturas posicionadoras. O equilíbrio entre o sujeito 'efeito' ideológico e sujeito agente ativo é uma variável que depende das condições sociais, tal como a estabilidade relativa das relações de dominação (FAIRCLOUGH, 2001, p. 121).

Assim, pretendo, neste ponto das análises, desvelar tais ideologias presentes nos discursos que circulam sobre os imigrantes bolivianos e averiguar se, de fato, a assertiva de Fairclough se mostra verdadeira no caso deles. Em outras palavras, pretendo identificar se, para os imigrantes bolivianos, é possível reestruturar as práticas e as estruturas posicionadoras, tornado-os em sujeitos agentes ativos e, se não, quais as razões/forças que os impedem neste sentido (FAIRCLOUGH, 1989).

Para lograr esse objetivo, pretendo valer-me da abordagem crítica de ideologia de Thompson (2002a) em que o autor destaca como operam as ideologias e quais são as estratégias que marcam a maneira como são construídas e legitimadas. Para Thompson (1995), deve-se averiguar se os fenômenos simbólicos estão, ou não, revestidos ideologicamente, pois, para ele, as relações de dominação são mantidas e naturalizadas na/ pela língua(gem). Portanto, pretendo neste recorte desta pesquisa, e baseando-me nos pressupostos teóricos da Análise de Discurso Crítica mencionados, identificar o problema social em que estão imbricados os imigrantes bolivianos em questão e quais são os obstáculos para a superação desse problema; investigar possíveis modos de ultrapassar tais obstáculos; refletir sobre as análises e, no final das contas, propor ações afirmativas em favor dos imigrantes.

Por fim, para considerar as perguntas de pesquisa relacionadas ao meu segundo objetos de estudo ${ }^{15}$, as identidades (des)construídas, opto por cimentar esta parte de minhas análises nesta pesquisa em um recorte da Teoria da Avaliatividade, como parte do quadro teórico da Linguística Sistêmico-Funcional. Este recorte será bastante apropriado e relevante para analisar um vídeo, e a reação a ele por parte dos participantes nesta pesquisa, em relação à sua questão identitária.

\footnotetext{
15 Considerarei à base dessa teoria as perguntas de pesquisa números quatro e cinco: a) Que imagens representativas de seu país de origem são mantidas e que outras se manifestam e se transmutam à construção da [nova] identidade coletiva e (bi)nacional? b) Como é (des)construída sua identidade a partir da decisão de sair de sua terra natal?
} 
O objetivo da Linguística Sistêmico-Funcional é entender como a língua é usada para produzir sentido enquanto processo social em sua relação com dado contexto sócio-histórico-cultural. Ademais, para a Linguística Sistêmico-Funcional, a língua é um sistema de redes e não um conjunto de estruturas dadas e prontas, possibilitando assim que diferentes significados, ou metafunções, sejam expressados simultaneamente (HALLIDAY; MATHIESSEN, 2004). Tais metafunções da língua(gem) são processadas nos níveis textual, interpessoal e ideacional.

Para fins de apropriabilidade nesta pesquisa, irei concentrar-me apenas na metafunção interpessoal que possibilita analisar a relação (social) entre os interlocutores de determinado texto, expressas por meio de suas opiniões, julgamentos e atitudes na/pela língua(gem).

Um dos domínios de evolução teórica mais recente no quadro da Linguística Sistêmico-Funcional é a Teoria da Avaliatividade que surgiu para:

[...] designar toda uma gama de recursos avaliativos da língua, incluindo os que são empregados pelos falantes para exprimir posturas, atitudes mentais e valores ou até para negociá-los com os seus interlocutores. Inclui, ainda, a consideração das atitudes, julgamentos e respostas emotivas dos falantes e o modo explícito, ou implícito, pressuposto ou assumido, como estão patentes nos enunciados (AZUAGA; AVELAR, 2003, p. 26).

A Teoria da Avaliatividade no domínio da Linguística Sistêmico-Funcional é organizada em subsistemas e os mesmos em categorias. Os subsistemas são: comprometimento, atitude e gradação. Nesta pesquisa vou centrar-me apenas no subsistema atitude, que é dividido em três categorias principais: afeto, julgamento e apreciação — todas relacionadas com os sentimentos, positivos e/ou negativos, dos interlocutores em situações de interação sócio-cultural, o que incluem reações emocionais, comportamento e avaliação (MARTIN; WHITE, 2005).

Dentro do espectro que proponho, considero que o enunciado que se releva na atitude avaliativa se refere a um conjunto de operações complexas relacionadas às posições que o falante, a cantora no vídeo em tela e os imigrantes que participam da pesquisa, revelam no que diz respeito à sua identidade fortemente influenciada por fatores sócio-culturais. Para que se tenha acesso a esse conjunto de operações complexas presente nos enunciados, é necessário identificar as diferentes instâncias do texto, que podem estar veladas ou não, e tentar interpretá-las no texto como um todo, seja este oral ou escrito (EGGINS, 2004). 
No escopo de uma análise linguística pautada pelo subsistema de atitude na Teoria da Avaliatividade, o falante pode assumir três posturas: uma relacionada à sua própria atitude em que ele emite sua opinião e se posiciona em relação a coisas, pessoas ou eventos; outra, em relação ao outro na interação de/entre enunciados; e, por fim, em relação ao texto ou intertexto ao fazer referências internas ou externas em relação aos enunciados. Notemos, portanto, que o falante/participante inter(age) de forma dialógica e/ou dialética, diluída e contínua com seu texto no espectro global.

Vejo esse modelo como sendo apropriado para esse recorte de meu corpora, pois trata justamente dos sentimentos dos interlocutores quando confrontados com a questão identitária, em especial no que diz respeito à sua dupla pertença. Portanto, entendo que a Teoria da Avaliatividade como uma ferramenta de análise da língua é bastante oportuna, em razão de que se refere a um dos recursos mais importantes na construção do significado interpessoal no domínio da atitude, da adoção de posturas e valores e na construção de identidades e gerência de posicionamentos nas relações entre os imigrantes (bolivianos) e a comunidade local, parte da nação acolhedora.

Nesse sentido, os estudos da língua(gem) por um viés crítico podem contribuir para que se identifique e, assim, busque eliminar práticas desonestas no domínio da organização social, desvelando as desigualdades que reinam na cena social em que se encontram os imigrantes bolivianos e lutando contra a englobante naturalização por meio da qual tais desigualdades são perpetuadas.

Nesta âncora número três, considerei a questão da(s) identidade(s) dos imigrantes bolivianos desde três distintas perspectivas: a da língua e linguagem, a das políticas linguísticas e a de algumas teorias linguísticas críticas. Espero ter contribuído para a ampliação da visão do leitor sobre o tema proposto nesta pesquisa.

Passemos ao quadro que epiloga o abordado.

Quadro 5 - Epilogando as identidades em movimento

Mateus, 2013

Hall, 2005
Destaquei que, por um viés crítico, a linguagem é concebida como um fato social que também perpetua relações de poder, de dominação e injustiça social num continuum, situado hierárquica, geográfica e sociohistoricamente. 
Considerei que o tema de identificação nesse movimento

Rajagopalan, 2006

Canagarajah, 1999b

Thompson, 2002a

Martin; White, 2005 identitário é uma reivindicação linguística e política em meio ao

turbilhão sociohistórico, político e cultural contemporâneo que tende a modificar a identidade primeira dos imigrantes bolivianos pela língua, o que denominei de xenolinguofobia.

Escolhi duas teorias linguísticas de cunho crítico para tratar dos meus objetos de estudo, a saber, a inclusão social e a (des)construção identitária dos imigrantes bolivianos. A pluralidade de discursos que refletem a complexidade interna e externa da sociedade. Através da linguagem, deve(mos) limpar a sociedade das desigualdades sociais que a transformam em um depósito de lixo social.

Fonte: Quadro elaborado pelo autor (2015)

Tendo cimentado meu texto neste capítulo, convém dar seguimento ao próximo apresentando ao meu leitor o percurso metodológico que adot[ar]ei neste texto e como este pode contribuir para um entendimento mais acurado das questões que envolvem os imigrantes bolivianos neste já supracitado bairro do centro-sul da capital de São Paulo.

Naveguemos, pois! 


\section{CAPÍTULO $3^{16}$}

\section{Percurso metodológico: "Navegar é preciso"}

Foto 4 - Por fim, navega o veleiro e seus mastros

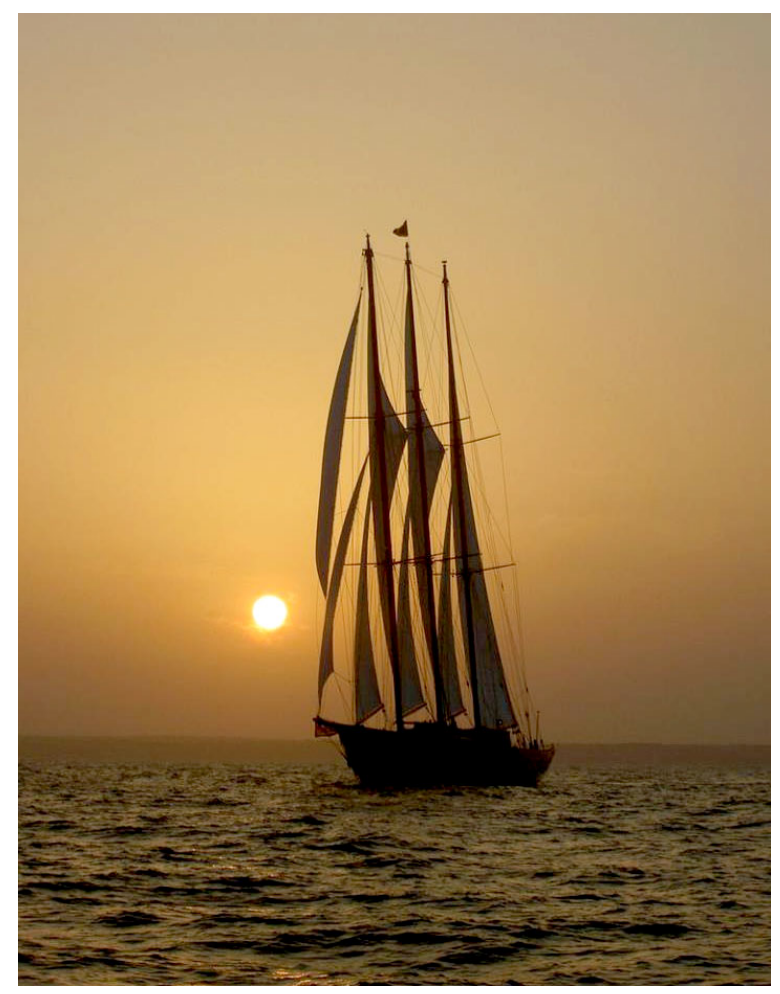

“Quando eu lembro do estalar do

chicote, meu sangue corre gelado $[\ldots]$

lembro do navio de escravos, quando brutalizavam a minha alma."

- Bob Marley

Fonte: Google ${ }^{17}$

\subsection{O desenho da pesquisa}

Pensar em pesquisa social implica pluralismo metodológico para que seja possível contemplar adequadamente os acontecimentos sociais objeto de determinada pesquisa. Para tanto, há que se considerar as dimensões do processo de pesquisa tanto no que se refere aos princípios que delineiam tal pesquisa quanto àqueles relativos à geração e análise de dados.

\footnotetext{
${ }^{16}$ A escolha pelos instrumentos de coleta de dados propostos nestes capítulo serve ao propósito de ajudar na compreensão das narrativas de vida dos assim (in)visibilizados imigrantes bolivianos em São Paulo e revelar a profundidade das questões socioinclusivas e identitárias à medida que, quiçá não em profundidade, revisito o conceitos abordados anteriormente neste texto.
}

${ }^{17}$ Disponível: http://correiodobrasil.com.br/fotos/navegar-e-preciso/592723. Acessado em 20/04/2015. 
Minha percepção, portanto, é que a pesquisa social senta suas bases em dados estreitamente relacionados à sociedade através de diferentes processos comunicativos cujo escopo central é trazer à baila a tessitura de dada teia social.

Não entendo que haja uma maneira ótima de se levar a cabo determinada pesquisa como superior a todas as demais, sejam elas de caráter qualitativo ou quantitativo. Creio, sim que, em certas pesquisas, uma maneira pode vir a ancorar a outra no todo ou em partes. Assim, é fundamental que o pesquisador social tenha visão holística do processo de pesquisa para que possa avaliar de maneira mais clara as diferenças funcionais de determinados métodos e correntes.

Portanto, minha pesquisa é consubstanciada numa abordagem qualitativa e de cunho etnográfico cujo objetivo é apresentar um exemplar representativo de diferentes pontos de vista que se correlacionam com o tema-objeto desta pesquisa (ANDRÉ, 1995). Trata-se de pesquisa de cunho etnográfico, pois assumo que, qual pesquisador, serei um ser estranho ao grupo sendo visto, inclusive, como alguém que pode vir a alterar ou interferir em suas vidas cotidianas. Meu intuito, portanto, será de minimizar esta interferência tanto quanto possa, inserindo-me no grupo com um papel a ser desempenhado e compartilhado. Voltando ao motivo da escolha pela abordagem qualitativa, ancoro-me na definição de Filstead por entender que há diferença entre esta e a quantitativa, além de sua melhor aderência à pesquisa em tela. Diz Filstead:

[...] métodos quantitativos e qualitativos são mais que apenas diferenças entre estratégias de pesquisa e procedimentos de coleta de dados. Esses enfoques representam, fundamentalmente, diferenciais epistemológicos para teorizar a natureza do conhecimento, a realidade social e os procedimentos para se compreender esses fenômenos. (FILSTEAD, 1979, p.45).

Como razões adicionais para minha escolha de abordagem, destaco que, sob minha ótica, a pesquisa social precisa ser reflexiva. Para tanto, esta não poderia, em primeiro lugar, ecoar apenas o positivismo kantiano e acrítico conforme postulado pelas crenças empírico-analíticas que produzem conhecimento nada além de nomológico e simétrico. Em segundo lugar, não poderia apropriar-se somente dos pressupostos das ciências históricohermenêuticas, cujo interesse estabelece-se, numa instância inicial, a partir da prática da linguagem comum com o fim de restaurar canais rompidos de comunicação, capturando a realidade social e capacitando o pesquisador a enxergar "através dos olhos dos que estão 
sendo pesquisados" (BRYMAN, 1988, p. 61). Por fim, esta deve fundar-se, sobretudo, aliada aos princípios básicos que regem as anteriores, nas ciências críticas que, embora não excluam a investigação empírico-analítica e vá além do entendimento histórico-hermenêutico, permite que a pesquisa seja auto-emancipatória e empodere os seus participantes.

Valho-me do postulado de Habermas para me justificar, pois ele sugere que a dinâmica autorreflexiva das ciências críticas, aliada a outras ciências de cunho sócio-histórico, podem ajudar o pesquisador a determinar a origem, a natureza e as características taxonômicas de estruturas condicionadas de poder que, acriticamente, apresentam-se como sendo inatas, lógicas e peculiares, mas são, de fato, o resultado de uma "comunicação sistematicamente distorcida e de uma repressão sutilmente legitimada" (HABERMAS, 1987, p. 371). Nessa mesma linha de raciocínio, apresento o pensamento de Zygmunt Bauman ao tratar da operacionalização do enfoque crítico-reflexivo em pesquisa social, quando, ao falar do processo de autenticação com vistas ao empoderamento e à emancipação na pesquisa social, afirma o seguinte: "O potencial emancipatório do conhecimento é posto à prova - e na verdade pode ser concretizado - somente a partir do diálogo, quando os objetos das afirmações teóricas se transformam em participantes ativos no processo incipiente de autenticação" (BAUMAN, 1976, p. 106).

Partindo, portanto, do anteriormente apresentado, entendo que minha pesquisa deve ser conduzida a partir dos pressupostos teórico-críticos descritos por se tratar de imigrantes bolivianos que aportaram no Brasil, mas especificamente na cidade de São Paulo, para fins de apropriabilidade geográfica, e cuja situação social deve ser investigada desde uma perspectiva crítica, visando à emancipação e ao empoderamento dos participantes da pesquisa, mas, também, com o suporte de cunho empírico-analítico e histórico-hermenêutico.

Assim, esta pesquisa configurar-se-á a partir de meu anseio em entender os processos implícitos e explícitos, linguísticos e sociohistóricos, na (trans)formação social e identitária dos imigrantes bolivianos em pauta, imbricados numa questão de (in)visibilidade na sociedade em que se inserem. Igualmente, quero compreender barreiras, impactos, ações positivas e negativas sob o viés da diversidade e representações (bi)nacionais transmutadas. Estou ciente de que navegar por essas águas representará um desafio, mas, ao mesmo tempo, propiciará satisfação a todos os participantes desta pesquisa, pois poder-se-á, ao seu final estabelecer-se ações propositivas, visando aos imigrantes bolivianos, objeto do estudo. 


\subsection{O lócus investigado}

Já apresentei ao leitor amigo, no preâmbulo deste texto, o cenário em que esta pesquisa está circunscrita, mas gostaria de repassá-lo organizando-o em itens:

Local da pesquisa: bairro Bom Retiro, região centro-sul de São Paulo, SP

Participantes: imigrantes bolivianos

Motivo da imigração para este local: pólo de modas e confecções

Forma de acesso: parentes, amigos e/ou intermediários no Brasil e na Bolívia

Condições de trabalho: insalubres, exaustivas e desumanas

Condições de vida: desconfortável e insalubre

Principais obstáculos: exploração, discriminação e maus tratos emocionais

Papel do pesquisador: de cunho etnográfico, pois está inserido no contexto social

\subsection{Os navegantes 18}

Passo agora a descrever os participantes de minha pesquisa, ou como numa viagem de navio, os navegantes que são os embarcados mais importantes numa viagem marítima. Utilizo o vocábulo navegantes aqui para referir-me aos imigrantes bolivianos que, como passageiros, numa viagem de navio, embarcaram em seus país de origem em busca do eldorado no Brasil. São navegantes também num sentido ambíguo, pois, embora tenham algum controle sobre o seu destino, não o têm no sentido absoluto, uma vez que não podem determinar o que lhes espera no novo destino. O seu futuro radica-se sobretudo em sonhos e esperanças.

Embora a comunidade boliviana no bairro Bom Retiro em São Paulo seja de uns 25 mil documentados e outros tantos indocumentados, procurei escolher, dentre os bolivianos, alguns que representassem as diferentes faces desse povo que reside no bairro paulistano. Meus critérios de seleção se resumem basicamente na escolha de bolivianos que representem diferentes estratos dentro da comunidade e que, em conversas prévias, colocaram-se à disposição e demonstraram bastante interesse em contribuir para a pesquisa, pois também se interessam em entender os conflitos que vivem e presenciam na comunidade.

\footnotetext{
${ }^{18}$ Os nomes dos participantes desta pesquisa são fictícios a fim de preservar sua identidade
} 
Por isso, convidei para participar da pesquisa uma boliviana solteira, que chamaremos de Dona Carolina, graduada em Letras na Bolívia e professora de Inglês, inclusive no Brasil. Tem 48 anos de idade, já é avó e cria a sua netinha, fruto do relacionamento de sua filha, também boliviana, com um jovem paraguaio. Sua filha tem 25 anos de idade e passou pelo menos metade de sua vida no Brasil. Também é mãe de um jovem, igualmente boliviano, de 21 anos de idade, e que vive no Brasil há pelo menos três terços de sua vida.

Ao segundo participante, chamaremos de Juan, também solteiro, 35 anos, sem filhos, boa formação educacional na Bolívia, pois graduou-se em Pedagogia e deu início aos seus estudos de pós-graduação latu sensu, abandonados por falta de recursos. Desembarcado no Brasil, no bairro Bom Retiro, há cerca de 5 anos. Fala muito pouco o Português, visto que tem tratos apenas com bolivianos e outros hispanoamericanos. Juan é o que podemos chamar de boliviano típico, não apenas nos traços físicos como também na postura, no falar, no comportamento, nos hábitos e costumes, na vestimenta, etc.

Meu terceiro convidado-participante será chamado de José, um jovem de 22 anos, nascido na Bolívia e que, orgulhosamente, ostenta seu documento como estrangeiro no Brasil, RNE (Registro Nacional de Estrangeiro), mas que foi criado e recebeu educação escolar no Brasil. Procura marcar sua identidade boliviana mantendo os hábitos alimentares, hábitos e costumes e valorizando o que é de sua terra natal, sobretudo a língua que permanece sem marcas do Português, ainda que fale este último muito bem e sem sotaque. Curiosamente, esse jovem rompeu a tradição de costura na família, qualificou-se profissionalmente e trabalha numa multinacional americana no setor de informática e atendimento ao público hispanoamericano, pelo que seu bom manejo tanto do Português como do Espanhol lhe foram bastante úteis.

Mariana será minha quarta participante. É filha de bolivianos, mas é nascida no Brasil. Trata-se de uma jovem com característica físicas que se confundem ora entre a das brasileiras ora das bolivianas, estudante do ensino médio, 16 anos, fala muito bem o espanhol, pois é membro de uma comunidade religiosa que utiliza apenas esse idioma em suas atividades. Embora marcada por essa dupla pertença Brasil-Bolívia, Mariana parece transitar bastante bem entre as duas culturas. Demonstra ser a mais bem resolvida do grupo. 
Por fim, a meu quinto e último participante, chamaremos de Senhor Pedro. Boliviano, sociólogo, 50 anos de idade, radicado no Brasil há uns 25 anos. No entanto, preserva todos os traços de seu país de origem, tais como os hábitos e costumes, alimentação, postura, modo de falar, etc. Entretanto, é curioso o fato de que o senhor Pedro, ainda que demonstre ser facilmente identificado como boliviano típico pelo descrito acima e tenha parco domínio do Português, consegue transitar com muito pouca dificuldade na comunidade local, tendo, numa primeira análise, absorvido as marcas identitárias locais.

Apresento na tabela abaixo um resumo acerca dos participantes da pesquisa:

Tabela 3 - Os participantes da pesquisa

\begin{tabular}{|c|c|c|c|c|c|c|}
\hline Participante & Idade & Estado Civil & $\begin{array}{c}\text { Profissão } \\
\text { na Bolívia }\end{array}$ & $\begin{array}{c}\text { Tempo de } \\
\text { Profissão } \\
\text { no Brasil }\end{array}$ & $\begin{array}{c}\text { Residência } \\
\text { no Brasil } \\
\text { (em anos) }\end{array}$ & $\begin{array}{c}\text { Situação } \\
\text { Documental }\end{array}$ \\
\hline Carolina & 48 & Divorciada & Professora & Costureira & 15 & Regular \\
\hline Juan & 35 & Solteiro & Pedagogo & Costureiro & 5 & Regular \\
\hline José & 22 & Solteiro & - & Tradutor & 18 & Regular \\
\hline Mariana & 16 & Solteira & - & Estudante & 16 & Brasileira \\
\hline Pedro & 50 & Casado & Sociólogo & Costureiro & 25 & Regular \\
\hline
\end{tabular}

Fonte: Tabela elaborada pelo autor (2015)

Gostaria de apresentar agora as razões para a escolha de poucos participantes para esta pesquisa. A primeira razão, óbvia, embora não evidente, refere-se à questão de espaço físico e logístico para a realização das atividades no grupo focal usado na coleta dos dados. Ademais, conforme mencionado no início desta consideração, os eleitos representam, com bastante propriedade, as diferentes faces dos bolivianos no bairro Bom Retiro da capital paulistana. Outra razão se justifica pelo meu entendimento de que, mesmo numa pesquisa dessa monta, há um número limitado de interpelações, ou versões da realidade, sobretudo quando se trata das peculiaridades de um povo. Daí a razão da escolha daqueles que, em minha ótica, representam os bolivianos que aqui residem. Em quarto lugar, porque nesta pesquisa concebo que os resultados de processos sociais, as representações e os temas de interesse comuns são, em grande parte, compartilhados por todos. Como motivo seguinte, penso que, para fins de saturação da pesquisa, em certo ponto dos trabalhos, não haverá novas surpresas ou 
percepções que justifiquem a presença de muitos outros bolivianos. A sexta razão para a escolha de poucos participantes é que meu objetivo nesta pesquisa é que ela seja mais verticalizada, ou seja, desejo uma análise mais aprofundada das questões objeto deste estudo, e menos horizontalizada; em outras palavras, espero alcançar maior qualidade na busca pela compreensão das inquietações relativas a este grupo de imigrantes. Por fim, coaduno com o professor Gaskell quando ele ao falar sobre o tamanho e a perda da qualidade do corpus diz:

Há uma perda de informação no relatório escrito, pois o entrevistador não é capaz de trazer cabalmente à memória o tom emocional do entrevistado, perguntas específicas, falas e comentários inicialmente sem sentido, mas que podem repentinamente, entrar em cena à medida que as contribuições de diferentes entrevistados são comparadas e contrastadas (GASKELL, 2013, p. $71)$.

Ressalto ainda que todos os dados serão gerados na língua dos participantes, ou seja, em espanhol. Entendo que lhes propiciar condições para que usem, sem quaisquer impedimentos ou constrangimentos, sua língua materna possibilitará que expressem suas atitudes, marcas identitárias nacionais e binacionais, cicatrizes de um histórico de exclusão e (in)visibilidade, e isso contribuirá para que os trabalhos no grupo focal sejam mais fluidos e dinâmicos.

Diante do exposto acima, concluo esta seção destacando que todos os bolivianos convidados a participar desta pesquisa consentiram e assentaram por escrito seu interesse e disposição de contribuir para o entendimento das questões levantadas neste texto. Esse será, em última instância, o fio de Ariadne de todos os envolvidos neste estudo, a saber, ajudar a comunidade boliviana a buscar alternativas de saída do labirinto social em se inserem.

\subsection{Os procedimentos de coleta}

Explicitando a priori alguns motivos pelos quais esta pesquisa não utilizará o método de amostragem, destaco que, em meu entendimento, este método carrega a ideia de levantamento com resultados generalizados, ainda que dentro de limites de confiabilidade. Ademais, uma vez que os critérios neste método não são possíveis de ser claramente definidos com vistas à representatividade lógica, concluo que este não se presta aos objetivos a serem atingidos em minha pesquisa com os imigrantes bolivianos na perspectiva adotada. 
Sendo assim, opto pela composição de um corpus na acepção de Roland Barthes ao defini-lo como "uma coleção finita de materiais, determinada de antemão pelo analista, com (inevitável) arbitrariedade, e com a qual ele irá trabalhar" (BARTHES, 1967, p. 96). Deste modo, minha noção de texto, no sentido aqui de corpus, é ampliada para qualquer tipo de material que possa servir de base para a minha pesquisa. Convergente com a concepção de Barthes, ressalto a definição do Oxford English Dictionary (1989) ao apresentar um corpus linguístico como "um material escrito ou falado sobre o qual se fundamenta uma análise linguística". E, amplio com o que dizem Bauer e Aarts quando mencionam que "os corpora são estruturados a partir de parâmetros, tais como canal, temática e função que podem, através de combinações de subcategorias, formar uma tipologia hierárquica de registros" (BAUER; AARTS, 2013, p. 45).

Vale destacar que, em minha pesquisa, constituirei um corpus tópico, entendendo-o como sendo planejado para um fim estruturante definido de pesquisa ao invés de um corpus geral, pois este presta-se apenas para pesquisas com um espectro de questões mais amplas.

Apoiado na definição apresentada pelo Oxford English Dictionary (op.cit.), meu corpus será construído com base no proposto por Barthes (op.cit.), quando, ao falar sobre os dados a serem coletados para sua composição, afirma que o pesquisador alista para o delineamento das categorias de coleta de itens como a relevância, a homogeneidade e a sincronicidade. O primeiro refere-se ao foco na temática da pesquisa, bem como na sua relevância. O segundo diz respeito à simetria dos dados, ainda que imagens, textos e entrevistas individuais e com grupos focais façam parte de um mesmo projeto de pesquisa, estes devem ser separados em diferentes (sub)corpora para fins de análise. Por fim, os dados a serem estudados devem pertencer a um mesmo ciclo natural, ou seja, devem ser sincrônicos.

Para fins de apropriabilidade e análise, meus dados de pesquisa serão divididos em duas dimensões do espaço social: estrato e representações (BAUER; AARTS, 2013). As representações configuram-se em um critério interno de análise para explorar espectros de opiniões. Nesta dimensão ressalto que não há corpus linguístico totalmente representativo, para propósitos gerais, com respeito a determinado tópico; portanto, esta não é minha pretensão nesta pesquisa, o que justifica o número de participantes. Por estratos, refiro-me à identificação dos participantes na pesquisa sendo esta de caráter externo. 
Para fins de ciência, destaco que, em minha pesquisa, as dimensões do espaço social estão pensadas em termos de estratos relacionados ao gênero, à idade, à educação, à etnia e à origem dos participantes, além de levar em conta as representações sociais de tais participantes, como as crenças, as atitudes, as ideologias, os hábitos e os estereótipos que marcam sua trajetória. Saliento que serão explicadas e detalhadas em profundidade no capítulo que tratará da análise de dados. Estou ciente que nesta pesquisa o fator tempo determinará o tamanho do corpus, a duração e a análise dos dados coletados e que grande quantidade de material coletado gerará "um incômodo atrativo" formando "porões de dados", ou seja, mais material do que poderei analisar (MILES, 1979). Entretanto, entendo que o tamanho do corpus que será gerado e sua subsequente análise contribuirão significativamente ao entendimento das inquietações-objeto desta pesquisa.

\subsubsection{Atividades no grupo focal ${ }^{19}$}

Concebo as atividades em um grupo focal como a técnica mais apropriada para a coleta de dados no formato de pesquisa que me proponho a realizar. Dentre as razões que justificam tal escolha, alisto primeiro minha compreensão de que o(s) mundo(s) da vida do(s) entrevistado(s), participando seja duma entrevista individual ou fazendo parte de um grupo focal especificado é a condição sine qua non da entrevista qualitativa, pois há o que podemos chamar de tríade dialógica, ecoando Bauer e Gaskell (1999), em que ocorre o representado pelo acrônimo SOS (sujeito-objeto-sujeito), ou seja, tanto o interlocutor no grupo focal quanto os participantes estabelecem uma relação de diálogo entre si e o objeto de pesquisa. Nomeio esta relação como sendo dialógica em minha pesquisa ainda que esteja ciente de que, em outras pesquisas, a relação possa ser marcada ora dialógica ora dialeticamente; visto que, qual pesquisador, não participo inteiramente do universo dos dados a serem gerados pelos imigrantes bolivianos, não creio que propiciarei momentos de pontos e contrapontos na construção da proposta-objeto da pesquisa, a saber, inclusão dos (in)visíveis socialmente e identidades em (des)construção. Outra razão para minha opção por um grupo focal, como método de coleta de dados, explica-se pelo que diz o professor Gaskell (2013):

\footnotetext{
${ }^{19}$ Encontrará no Apêndice A: fragmentos de atividade no grupo focal elaborada pelo autor
} 
Toda pesquisa com entrevistas é um processo social, uma interação ou um empreendimento cooperativo, em que as palavras são o meio principal de troca. [...] é uma interação, uma troca de ideias e de significados, em que várias realidades e percepções são exploradas e desenvolvidas. [...] tanto o entrevistador quanto os entrevistados são envolvidos na produção de conhecimento (GASKELL, 2013, p. 73).

Assumindo as palavras do professor Gaskell por um viés mais amplo, concebo que o grupo focal seria uma técnica bastante suficiente para contemplar meu objetivo, ou seja, propiciar que a entrevista seja, de fato, parte de um processo social interativo e cooperativo na qual as realidades dos imigrantes bolivianos serão percebidas, exploradas e desenvolvidas.

Vale ressaltar que, visando ao sucesso dos trabalhos sob a tutela do interlocutor, devese levar em consideração que o ambiente ou cenário(s) da(s) entrevista(s) não pode contribuir a que haja qualquer tipo de constrangimento, hesitação defensiva por parte dos entrevistados, mas, antes, deve-se estabelecer relação de confiança, respeito e senso de segurança. Destarte, a escolha por grupos focais, ou grupos naturais, se dá baseada na acepção de que os participantes interagem em conjunto e compartilham de um passado comum, com interesses e valores semelhantes além de serem inseridos num mesmo contexto social, o que contribui para a interação mais autêntica e cooperação entre eles.

Parafraseando Habermas (1992) ao falar da esfera pública ideal, Gaskell (2013) descreve bem o que carateriza um grupo focal ao dizer que neles:

O debate é aberto e acessível a todos: os assuntos em questão são de interesse comum; as diferenças de status entre os participantes não são levadas em consideração; e o debate se fundamenta em uma discussão racional [...] o que não significa que seja lógica e desapaixonada. O debate é uma troca de pontos de vista, ideias e experiências, embora [talvez] expressas emocionalmente e sem lógica, mas sem privilegiar indivíduos particulares ou posições (GASKELL, 2013, p. 79).

Salta-me aos olhos chamar o professor Gaskell de debate o desenvolvimento, o fluir das atividades no grupo focal. Isto adere perfeitamente ao meu objetivo com os participantes do grupo, ou seja, promover um debate mais amplo, marcado pelas diferentes cosmovisões, atitudes, interesses, percepções, ideologias, etc. dos imigrantes bolivianos que participarão dos trabalhos nesta pesquisa. Será nesta discussão racional, imparcial, numa perspectiva de trocas de (pre)conceitos e experiências em que os participantes tornarão patentes os construtos inclusão dos (in)visíveis e a (des)construção de sua identidade (bi)nacional. 
Conforme preconizam Gordon e Langmaid (1998), a sessão no grupo focal a que me proponho terá a duração de 120 (cento e vinte) minutos com 05 (cinco) participantes e formatada conforme as fases sintetizadas no tabela abaixo:

Tabela 4 - Organização das atividades no grupo focal

\begin{tabular}{|c|c|l|}
\hline Fase & Duração & \multicolumn{1}{|c|}{ Atividade(s) } \\
\hline 1 & $10 \mathrm{~min}$ & Formação: organização conforme características individuais \\
\hline 2 & $30 \mathrm{~min}$ & Procelosa: identidades em conflito - encontros e desencontros \\
\hline 3 & $10 \mathrm{~min}$ & Estabelecimento da ordem: momento de equalização e coesão do grupo \\
\hline 4 & $50 \mathrm{~min}$ & Empreendimento: auge dos trabalhos, período de fluidez e dinamismo \\
\hline 5 & $20 \mathrm{~min}$ & Arremate: informalidade conversacional sem registro audiovisual \\
\hline
\end{tabular}

Fonte: Tabela elaborada pelo autor(2015)

Ampliando o entendimento dos procedimentos de entrevista no grupo focal de minha pesquisa, destaco que a primeira fase, baseada em um guia proposto pelo interlocutor, tem como objetivo o conhecimento do outro, ou seja, os participantes interagirão entre si a fim de familiarizarem-se melhor uns com os outros segundo suas características pessoais individuais. $\mathrm{Na}$ fase seguinte, a meta é explorar o espectro de atitudes, opiniões e comportamentos, bem como os processos de consenso e divergência associados ao eixo central da pesquisa. $\mathrm{Na}$ terceira fase, os participantes terão sanado quaisquer eventuais brechas conceituais em relação aos trabalhos e formarão um grupo coeso em torno de um objetivo comum. $\mathrm{O}$ auge das atividades do grupo será na fase 4, quando os participantes, com o suporte de ferramentas audiovisuais, perguntas-guia, imagens e fotos de cunho pessoal, comida típica, etc., trarão à baila suas impressões implícitas e explícitas de sua experiência como imigrantes no Brasil, (des)velando, assim, como sua identidade (bi)nacional é (des)construída e se se sentem incluídos ou (in)visibilizados na sociedade local. Por fim, na última fase, os participantes, de forma mais relaxada, continuarão suas contribuições à temática da pesquisa, mas, desta feita, sem o registro audiovisual formal e, sim, por breves notas de campo do interlocutor.

Estou ciente que há limitações relacionados a esta técnica de coleta de dados. Dentre elas destaco que, como interlocutor, talvez não possa compreender plenamente toda a linguagem local, ou seja, alguns traços comunicativos caracterizados por marcas identitárias 
próprias do imigrante boliviano. Ademais pode haver omissão de detalhes importantes por parte dos participantes do grupo, assim como a projeção de uma visão distorcida por este, e que é pouco provável de ser testada ou verificada pelo interlocutor. Entretanto, tais limitações não invalidam este método, pois devem ser consideradas e tratadas como forma bastante completa de informação [de ordem] sociológica (BECKER; GEER, 1957). Em outras palavras, refiro-me aos dados que serão coletados como sendo uma rica fonte de informação que poderá, a posteriori, ser explorada e utilizada para outros fins de investigação.

Apresento a seguir os instrumentos que utilizarei na técnica: entrevista com grupos focais, cujo objetivo é contribuir para a construção do corpus linguístico. Tais instrumentos serão, no período de análise, recortados e constituídos em diferentes corpora.

\subsubsection{Notas de campo ${ }^{20}$}

Abro aqui um breve parêntese para tratar das notas de campo que, embora não sejam meus principais métodos de coleta de dados, terão uma função ora como apoio ao interlocutor ora como ferramenta de complementação da coleta de informações no andamento das atividades em seu momento de fluidez e dinamismo no grupo focal.

É sabido que, em pesquisa social, em especial com as notas de campo como principal método de coleta, há certa ansiedade em relação à polaridade 'anotar tudo' versus 'não perder nada'. Ressalto que esta não é minha preocupação, pois, embora entenda que as notas de campo numa pesquisa social, qualitativa e de cunho etnográfico, sejam uma representação escrita de uma cultura que implica uma escrita de forma regular e sistemática baseada em observação e apreensão da rotina dos participantes, não tenciono que minha pesquisa se configure a partir de registros escritos, sejam estes formais ou informais.

A principal razão para isto e para a não adoção das notas de campo como um método primário em minha pesquisa é que compreendo que, ao assentar por escrito o conteúdo da observação, há o risco de os meus muitos filtros pessoais alterarem ou mal interpretarem o que os participantes (não) quiseram dizer, emoldurando, assim, o evento observado.

\footnotetext{
${ }^{20}$ Encontrará no Apêndice B: um fragmento de nota de campo feita pelo autor
} 
Diante do exposto, não se faz necessário espraiar-me sobre a definição e os usos das notas de campo conforme salientam pesquisadores como Gibbs (2009) e van Maanen (2011).

\subsubsection{Histórias de vida: narrativas escrita ${ }^{21}$ e visual ${ }^{22}$}

Flick (1998) também aborda as narrativas, ou histórias de vida, como instrumentos de pesquisa qualitativa, embora se refira a elas como entrevistas episódicas, termo e definição esta que não se ajusta, nem se aplica à minha pesquisa por se tratar de um tipo de entrevista que visa prioritariamente à comparação entre situações de diferentes grupos sociais.

Concebo, em minha pesquisa, as histórias de vida como narrativas em que os participantes contarão sua vida, focando no todo ou em partes que sejam relevantes ao propósito do estudo. Optei que o fizessem através de narrativas escrita e visual ${ }^{23}$. Consideroas como parte de um estudo transecional, visto que as histórias de vida não se referem apenas ao presente, mas incluirão reconstruções do passado dos participantes na pesquisa. Por se tratar de uma narrativa espontânea, o pesquisador-interlocutor se abstém de intervenções diretivas, permitindo ao participante discorrer à larga sobre o tema proposto. Portanto, dentro do que posso chamar de grande guarda-chuva que é o grupo focal, as usaremos como outra ferramenta para coleta de dados. Categorizo-as assim, pois coaduno com a descrição feita por Hermanns quando ele discorre sobre narrativas:

Em primeiro lugar uma situação inicial é esboçada (como tudo começou), e então os acontecimentos relevantes para a narrativa são selecionados de todo o conjunto e apresentado como uma progressão coerente dos mesmos (como as coisas se desenvolveram), e finalmente é mostrada como ficou a situação final do desenvolvimento (o que aconteceu) (HERMANNS, 1995, p. 183).

\footnotetext{
${ }^{21}$ Encontrará no Apêndice C: fragmentos de narrativas escritas compartilhadas com o autor

22 Encontrará no Apêndice D: exemplos de narrativas visuais apresentadas ao autor

${ }^{23}$ Embora todo o processo, ou as histórias de vida, no grupo focal, tenham sido também registradas por meio de uma entrevista (veja apêndice A) e oralmente, através de áudio e vídeo, estes não constituem minha principal fonte de dados nesta pesquisa. São dados secundários que serão usados em alguns momentos, se necessários, para exemplificar e/ou reforçar os achados nas narrativas escrita e visual e nos comentários dos participantes.
} 
Convergindo com Hermanns, entendo que minha situação inicial será o grupo focal em que os trabalhos serão desenvolvidos com vistas a culminar com as histórias de vida que, como um dos pontos máximos do grupo focal, possibilitarão ao participantes falar abertamente de suas experiências como imigrante de origem boliviana no Brasil.

Visto que todo o pensamento humano é organizado de forma lógica e racional por um lado, também o é de modo narrativo e descritivo por outro, ou seja, as experiências humanas são organizadas em episódios temporalmente significativos, pelo menos a priori. Sendo assim, o mesmo autor define em termos bastante didáticos a narrativa ou história de vida:

[...] pede-se ao informante que forneça, em uma narrativa improvisada, a história de uma situação de interesse de que o entrevistado participou ... A tarefa do entrevistador é fazer com que o informante conte a história da área de interesse em questão como um história consistente a partir de todos os acontecimentos relevantes, desde o início, até o fim (HERMANNS, 1995, p. 184).

Para fins de apropriabilidade, não adoto os termos informante e entrevistador, conforme sugere Hermanns, mas prefiro chamar os imigrantes bolivianos de participantes, visto concebê-los como atores intrinsecamente envolvidos no objeto deste estudo. Nessa mesma linha de raciocínio, opto por chamar o pesquisador de interlocutor, pois entendo que este termo define melhor o meu trabalho durante os trabalhos no grupo focal.

Uma razão adicional para propor que as histórias de vida sejam narradas no bojo das atividades do grupo focal é que a influência do interlocutor será mínima, uma vez que o ambiente, já preparado para as atividades do grupo, é, igualmente, propício para que as narrativas de vida ocorram, não justificando desmonte de toda essa estrutura e uma nova e posterior montagem apenas para separar instrumentos de coleta de dados.

Os procedimentos a serem adotados para que se concretizem as narrativas são apresentados na tabela abaixo e organizados em quatro etapas distintas e correlacionadas. 
Tabela 5 - Etapas da contação das histórias de vida 24

\begin{tabular}{|c|c|}
\hline Etapa & Atividade(s) no Grupo Focal \\
\hline 1 & Questões exmanentes: perguntas pré-preparadas pelo interlocutor \\
\hline Recepção & Questões imanentes: formulações que surgirão durante a narrativa \\
\hline $\begin{array}{l}2 \\
\text { Preparação }\end{array}$ & $\begin{array}{l}\text { Entrevista semi-estruturada aos participantes da pesquisa visando a coleta de } \\
\text { informações sobre objetos de estudo: inclusão e identidade }\end{array}$ \\
\hline $\begin{array}{l}3 \\
\text { Inclusão }\end{array}$ & $\begin{array}{l}\text { Elucidação do tópico geral a partir de um vídeo e fotos/imagens da Bolívia } \\
\text { Composição das histórias de vida: narrativas escrita e visual }\end{array}$ \\
\hline $\begin{array}{c}4 \\
\text { Identidade }\end{array}$ & $\begin{array}{l}\text { Participantes assistem a um videoclipe que aborda a questão da identidade de } \\
\text { imigrantes que é afetada pela partida de sua terra natal e chegada a outro país. } \\
\text { Em seguida, escrevem um comentário breve sobre suas impressões do vídeo. }\end{array}$ \\
\hline
\end{tabular}

Fonte: Tabela elabora pelo autor (2015)

$\mathrm{Na}$ primeira e segunda etapas das atividades relacionadas às histórias de vida, o interlocutor apresentará as questões, que aqui chamo de exmanentes, ou seja, aquelas cujo interesse primário é do pesquisador-interlocutor previamente formuladas e com uma linguagem moderada. Ainda nesta etapa, explicarei aos participantes que talvez surjam perguntas imanentes que são aquelas cujo objetivo é manter a fluidez das narrativas e o alcance da metas formuladas na perguntas exmanentes. Nesta fase, o objetivo é preparar a mente dos participantes para a atividades no grupo focal e situá-los quanto ao teor da pesquisa.

$\mathrm{Na}$ terceira e quarta etapas das atividades, considerarei as respostas das perguntas de pesquisa números dois a cinco. O foco dessas duas etapas e as perguntas de pesquisa correspondentes residem no entendimento pleno do objeto de estudo à luz dos dois recortes teóricos que escolhi. No bojo das atividades no grupo focal, o pesquisador-interlocutor fará algumas anotações/notas de campo que considerei relevantes e que poderão contribuir para ampliar a compreensão dos assuntos abordados com os participantes da pesquisa.

\footnotetext{
${ }^{24}$ As informações colhidas durante as etapas um e dois das atividades no grupo focal, foram registradas em audio, vídeo e no preenchimento de uma entrevista semi-estruturada. Entretanto, esses não compõem a parte principal do corpora que será analisado. Servirão apenas para complementar as informações fornecidas pelos participantes da pesquisa, sempre que eu achar relevante e necessário.
} 
3.4.2. Áudio, vídeo ${ }^{25}$ e imagens ${ }^{26}$ : à guisa de esclarecimento

Em conclusão desta seção sobre coleta de meus dados, vejo como pertinente esclarecer alguns fatores que me levaram a escolha de tais ferramentas.

Inicialmente, porque através do áudio, do vídeo e das imagens ou fotos os participantes serão estimulados a comentá-los e, desse modo, poderão tanto explicar o seu conteúdo como terem suas memórias, opiniões e comentários de valor evocados. Ademais, alisto a seguir três outros motivos conforme delineados por um renomado antropólogo social e produtor de filmes com mais de cinquenta trabalhos na área:

[...] a imagem, com ou sem acompanhamento de som, em movimento ou não, oferece um registro restrito, mas poderoso das ações temporais e dos acontecimentos reais - concretos e materiais.;

[...] embora a pesquisa social esteja tipicamente a serviço de complexas questões teóricas e abstratas, ela pode empregar, como dados primários, informação visual que não necessita ser nem em forma de palavras escritas, nem em forma de números $[\ldots]$;

A terceira razão, [...] é que 'o visual' e 'a mídia' desempenham papéis importantes na vida social, política e econômica. Eles se tornaram "fatos sociais", no sentido de Durkheim. (LOIZOS, 2013, p.137,138)

Conforme salienta o autor acima, minha pesquisa poderá ser facilitada se tenho preparados de antemão recursos imagéticos e audiovisuais, pois eles podem fazer ressoar as memórias submersas dos imigrantes bolivianos em que todos os participantes no estudo podemos - aqui também sou incluído - construir as histórias de forma partilhada, "talvez de uma maneira mais descontraída do que sem tal estímulo" (LOIZOS, 2013, p. 143). Alinhado com o acima e em convergência com minha pesquisa com os bolivianos, Sheena Crawford (1987) afirma que os recursos imagéticos e audiovisuais em pesquisa social constituem uma ressonância icônica aos imigrantes, reportando-os às suas origens.

Ampliando um pouco mais o uso do vídeo, saliento que a opção pelo seu uso se deveu ao fato de que algum "conjunto de ações humanas é complexo e difícil de ser descrito compreensivamente” apenas por observação (não) estática (LOIZOS, 2013, p. 149). Portanto,

\footnotetext{
${ }^{25}$ Encontrará no Apêndice E: foto e fonte dos videoclipes apresentados pelo autor aos navegantes

${ }^{26}$ Encontrará no Apêndice F: exemplos de imagens da Bolívia usadas pelo autor
} 
o uso de um vídeo que aborda as questões que fazem parte dos objetos deste estudo contribuirão sobremaneira para que se atinja o objetivo a que este se destina.

Estou ciente das limitações que o uso de tais recursos me impõem. Um deles se refere à verificação cabal de autenticidade e autoria de todos os recursos imagéticos e audiovisuais a serem utilizados nesta pesquisa. Entretanto, ressalto que, embora sejam envidados incansáveis esforços neste requisito, meu contexto de pesquisa não se prestará à exaustão na busca por tal verificação, pois os recursos são de domínio público e não serão usados para divulgação, mas, antes, apenas para instigar os participantes da pesquisa a trazer à baila seus sentimentos. Ainda assim, por questões éticas, as informações pesquisadas com base nesses recursos permanecerão restritas e confidenciais sendo referidas somente na análise do corpus.

Quadro 6- Os caminhos que seguirei na pesquisa

Bom Retiro: bairro localizado na região centro-sul da cidade São

Lócus

Paulo, conhecido como um dos mais relevantes pólos de moda e de confecções no país. Os imigrantes são atraídos pelo trabalho.

Dona Carolina, 48 anos, graduada em Letras, solteira, mãe e avó; é dona de oficina de costura.

Juan, 35 anos, sem filhos, pedagogo, solteiro, é costureiro.

Os navegantes

José, 22 anos, solteiro, sem filhos, é tradutor português-espanhol numa multinacional, mora no Brasil desde os 4 anos.

Mariana, 16 anos, solteira, sem filhos, estudante.

Senhor Pedro, 50 anos, sociólogo, casado, tem a filha mais velha nascida na boliviana e a caçula é brasileira, no Brasil há 25 anos.

Atividades no grupo focal (GASKELL, 2013)

* Notas de campo (van MAANEN, 2011)

\section{Procedimento de coleta}

* Histórias de vida (FLICK, 1998)

* Narrativas escritas e visuais (HERMANNS, 1995)

* Áudio e vídeo (LOIZOS, 2013)

* Imagens (CRAWFORD, 1987)

Fonte: Quadro elaborado pelo autor (2015) 
Nesse capítulo, que aborda meu percurso metodológico, busquei apresentar um referencial teórico de modo claro, abrangente e coerente com meus objetivos nesta pesquisa. Meu esforço investigativo carecerá de suporte aprofundado e entendo que o percurso adotado possibilitará que eu atinja este alvo. No próximo capítulo, apresentarei retomarei tanto o referencial teórico para a análise dos dados de minha pesquisa quanto a própria análise particular desses dados em resposta às minhas perguntas de pesquisa.

\section{CAPÍTULO 4}

\section{A análise dos dados: primeira atracagem em um cais}

Foto 5 - Atraca-te, pois!

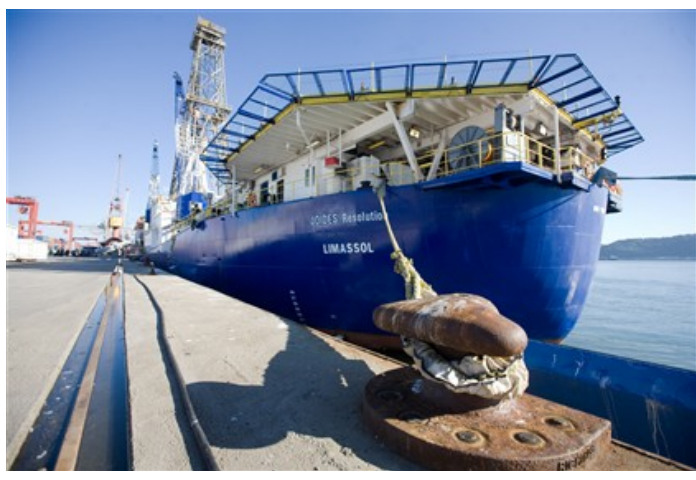

"O comboio abranda, é o

Cais do [Porto].

Cheguei a [São Paulo], mas não a uma conclusão.”

- Fernando Pessoa

Fonte: Google 27

A chegada a um cais após uma jornada propicia duplo movimento entre o passado recente e o presente recém-alcançado. Entendo eu, portanto, que é nesse momento que um imigrante inicia o árduo processo de compreensão, equalização, fusão e acomodação dos momentos localizados em ambas as etapas na corrente do tempo. Evidentemente, assevero eu, a língua desempenha papel fundamental sobretudo se se trata de imigrantes recém-atracados em uma terra distinta e longínqua da sua. Pois bem, é neste contexto que se inserem os imigrantes bolivianos neste momento de meu texto. Ao analisar os dados coletados através dos diferentes instrumentos de coleta, considerados no capítulo anterior, pretendo, no mote

${ }^{27}$ Disponível: http://www.dn.pt/inicio/ciencia/interior.aspx?content_id=2249670. Acessado em 20/04/2015 
de minhas hipóteses de pesquisa, desvelar como as escolhas linguísticas e as atitudes conscientes ou inconscientes, voluntárias ou não - dos imigrantes bolivianos na capital paulista associam-se à sua afirmação identitária e às práticas socioinclusivas a que são submetidos quer voluntariamente quer não. Naveguemos, leitor amigo!

Artigo VI

Toda pessoa tem o direito de ser, em todos os lugares, reconhecida como pessoa perante a lei.

Artigo VII

Todos são iguais perante a lei e têm direito, sem qualquer distinção a igual proteção [...] contra qualquer discriminação e contra qualquer incitamento [a esta].

\section{— Declaração Universal dos Direitos Humanos 28}

ONU, 10 de dezembro de 1948.

Lara e Limberti (2015) destacam que historicamente o dominador é quem conta a História desde sua ótica, silenciando os dominados, os socialmente segregados, que são obrigados a buscar as brechas ou fissuras no sistema para que possam se fazer ouvir. Dizem:

Um dos aspectos mais perversos [dessa] segregação diz respeito aos problemas identitários, aos problemas de falta de espaço, aos problemas de intolerância e de preconceito que os indivíduos sofrem e vivenciam. Tal segregação pode ocorrer de forma aberta ou de forma velada. Esta última talvez seja a mais perversa por significar, simulando que não significa. Afinal, afirmar que se aceita o outro, mas querê-lo convenientemente a distância, "confinado" em seu "próprio" espaço, não é aceitação real. Por mais que nos esforcemos em negar a presença do outro - já que "diferente" de nós - , ele está em todos os lugares; é sobretudo um problema social, mas que traz em seu bojo outros fatores: históricos, políticos, econômicos e, por que não dizer, discursivos" (LARA; LIMBERTI, 2015, p. 7, 8).

A fala das autoras citadas parece sintetizar o que ocorre com os imigrantes bolivianos aqui em São Paulo e o que temos tratado neste texto. A partir deste ponto, quero compartilhar

\footnotetext{
${ }^{28}$ Declaração Universal dos Direitos Humanos. Adotada e proclamada conforme a resolução número 217-A na III da Assembléia Geral das Nações Unidas em 10 de dezembro de 1948. Disponível na Biblioteca Virtual de Direitos Humanos da Universidade de São Paulo, SP, Brasil: www.direitoshumanos.usp.br. Acessado em 20/04/2015.
} 
com o leitor minhas impressões, minhas análises do material coletado junto aos participantes. Sei que não conseguirei apresentar um análise num grau de profundidade que capte todos os sentidos dos enunciados dos imigrantes bolivianos que participaram em minha pesquisa, até porque me faltaria tempo, espaço [textual] e, porque não dizer talvez até competência e maturidade acadêmica, para analisar em minúcias todo o material coletado. Portanto, saliento que o que apresentarei como dados a serem analisados são apenas uma mostra representativa do meu corpora. Muito ficará nos porões de dados carecendo de revisita e análise futura, conforme considerarei nas proposições finais (MILES, 1979).

Gostaria de salientar que minhas análises partirão do princípio de teorias linguísticas múltiplas e críticas em seu caráter. Em outras palavras, quero dizer que em vez de aferrar-me a uma teoria ou vertente linguística única para analisar os discursos que emergirão de minha coleta de dados, procurarei buscar em diferentes vertentes teóricas os elementos necessários para enfeixar o diálogo entre os construtos/objetos desta pesquisa: inclusão social e identidade dos imigrantes bolivianos.

Uma razão de minha escolha é que, dada a complexidade e a riqueza dos fatos e dos participantes envolvidos nessa maré da linguagem, entendo que um arcabouço teórico interdisciplinar, no sentido de abarcar mais de uma vertente, e transdisciplinar, tanto no sentido de objeto de estudo como no sentido de transgressão, poderão melhor subsidiar minhas análises e abrir a possibilidade de uma visão mais ampla e abrangente do tema. Outro motivo que me faz optar por essa abordagem metodológica múltipla é entender que alguns fenômenos da linguagem podem ser melhor contemplados, explicados e compreendidos por uma vertente ou teoria linguística do que por outra(s). Desse modo, ater-me a apenas uma das teorias linguísticas disponíveis na atualidade poderiam empobrecer, e/ou não dar conta de modo satisfatório, de algum modo, da minha compreensão do fenômeno da imigração boliviana em São Paulo.

Essa abordagem crítica que adoto encontra eco nas palavras do Professor Rajagopalan:

[...] a conscientização de que trabalhar com a linguagem é intervir na realidade social da qual ela faz parte. Linguagem é, em outras palavras, uma prática social. A linguística é uma prática social como qualquer outra e tem por seu objeto a linguagem (RAJAGOPALAN, 2003, p. 126). 
Pennycook (2001, p. 173), ao falar sobre o tema que proponho, diz que este é "um modo de pensar e fazer que está sempre questionando, sempre procurando novos esquemas de politização". Ou seja, este conceito de (inter)(trans)disciplinaridade constitui-se um desafio para as formas tradicionais de organização do conhecimento, ou análises linguísticas, como se elas fossem igrejas acadêmicas e, pior ainda, revestidas do mais alto grau de dogmatismo. Assim, ancoro-me, e fundamento minha decisão, na sábia pergunta da Professora Maria Antonieta Celani da PUC/SP: "Há lugar para reinos no domínio do saber?” (1998, p. 142).

A pergunta da Professora Celani (op.cit.) converge com o que penso sobre filiar-me a apenas uma corrente teórica com se esta única fosse detentora da verdade linguística e não houvesse outras que pudessem, com o mesmo vigor, contribuir para o meu trabalho. Neste sentido, e reforçando ainda mais meu argumento, ecôo as palavras do professor Vilson Leffa:

Depois de tanta decepção com as promessas feitas e não cumpridas por diferentes teorias, parece que chegamos à conclusão de Diderot de que a verdade é uma prostituta: dorme com todos é não é fiel a ninguém. Metaforicamente pode-se afirmar que as teorias não têm o direito de exigir admiradores que se casem monogamicamente com elas para o resto da vida; as teorias devem ter apenas usuários, de preferência com alto índice de infidelidade e mesmo de promiscuidade, se for o caso. Diante de uma teoria é melhor ser promíscuo do que fiel. A história não caminha se as teorias não forem traídas (LEFFA, 2003, p. 8, 9).

A ideia apresentada por Leffa (op.cit.), e que eu advogo neste texto, se refere a um processo de transformação e incorporação de distintas vertentes teóricas em linguística, num continuum de mestiçagem e não de substituição de uma, que se arroga superior ou mais completa, por outra. A experiência que observo em outros campos de pesquisa demonstram que essa abordagem é bastante profícua, pois é de fácil constatação a "promiscuidade", a "prostituição" em diferentes pesquisas em ciências sociais, ciências exatas e biológicas e outros tantos campos de investigação. Portanto, proponho em meu texto que nós, linguistas, nos prostituamos, que sejamos promíscuos para que possamos entender com melhor nitidez e clareza os problemas sociais que nos propomos a investigar e, como já disse em outro momento neste texto, que possamos intervir na dor que sofrem nossos objetos de pesquisa.

Branca Falabella Fabrício (2008, p. 28) diz que os estudos linguísticos devem ser reinventados e sugere, por exemplo, os pensamentos de Nietzsche, Foucault e outros como contribuintes para que essa "desaprendizagem como possibilidade de conhecimento" possa ser trazida à baila. Em outras palavras, ela sugere que uma nova agenda político-linguística 
pautada pelo viés crítico e reflexivo em sua prática deve servir para que (re)avaliemos as construções epistemológicas que, conscientemente ou não, parece que nos fazem esquecer que a língua(gem), o coração-cérebro de nossa existência como linguistas, está envolvida numa tecido social complexo, extrema e velozmente movediço e conflituoso.

Portanto, espero contribuir com minhas análises para sua satisfação, leitor amigo, que me acompanha desde as primeiras páginas desse texto e, certamente, interessa-se pelo que acontece com os imigrantes bolivianos em São Paulo tragados pelo olho desse furacão social.

Sintetizo no quadro a seguir como estarão organizadas minhas análises e a relação entre os objetos de estudos, teorias linguísticas críticas e minhas perguntas de pesquisa.

Quadro 7 - As análises linguísticas 29

\begin{tabular}{|c|c|c|c|}
\hline $\begin{array}{l}\text { Objeto de } \\
\text { estudo }\end{array}$ & $\begin{array}{l}\text { Teoria Linguística } \\
\text { Crítica }\end{array}$ & $\begin{array}{l}\text { Instrumento(s) de } \\
\text { Coleta de Dados }\end{array}$ & Perguntas de Pesquisa \\
\hline Inclusão & $\begin{array}{l}\text { Análise de } \\
\text { Discurso Crítica, } \\
\text { com foco central } \\
\text { n a a bordage m } \\
\text { crítica de ideologia } \\
\text { (Thompson, 2002a) }\end{array}$ & $\begin{array}{l}\text { Histórias de vida: } \\
\text { narrativas escrita e } \\
\text { visual. Impressões } \\
\text { a partir de fotos e } \\
\text { videoclipe }\end{array}$ & $\begin{array}{l}\text { * Assumindo que há desníveis e } \\
\text { disparidades marcadamente } \\
\text { ideológicos, excludentes e } \\
\text { discriminatórios, no trato com os } \\
\text { imigrantes bolivianos, que } \\
\text { atitudes são reveladas por suas } \\
\text { escolhas linguísticas ao falar da } \\
\text { inclusão e (in)visibilidade? } \\
\text { * Como as histórias de vida, dos } \\
\text { assim (in)visibilizados imigrantes } \\
\text { bolivianos em tela, revelam a } \\
\text { profundidade das questões de } \\
\text { inclusão em âmbito local? }\end{array}$ \\
\hline
\end{tabular}

${ }^{29}$ As hipóteses de pesquisa de dois a cinco serão visitadas e revisitadas tanto nas análises feitas a partir do referencial teórico da Análise de Discurso Crítica, com foco na abordagem crítica de ideologia, como na Teoria da Avaliatividade como parte dos pressupostos da Linguística Sistêmico-Funcional. 


\begin{tabular}{|c|c|c|c|}
\hline Identidade & $\begin{array}{l}\text { Recorte da Teoria } \\
\text { da Avaliatividade, } \\
\text { da LSF } \\
\text { (Martin; } \\
\text { White, 2005) }\end{array}$ & $\begin{array}{l}\text { Videoclipe musical } \\
\text { e impressão escrita }\end{array}$ & $\begin{array}{l}\text { * Que imagens representativas do } \\
\text { país de origem são mantidas, e } \\
\text { que outras se manifestam e se } \\
\text { transmutam construção da [nova] } \\
\text { identidade coletiva e (bi)nacional? } \\
\text { * Como é (des)construída sua } \\
\text { identidade a partir da decisão de } \\
\text { sair de sua terra natal? }\end{array}$ \\
\hline
\end{tabular}

Fonte: Quadro elaborado pelo autor (2015)

\subsection{Análise de Discurso Crítica: ideologias imersas e inclusão dos (in)visíveis}

A história tem sido marcada, ao longo dos anos, por um vai-e-vem de inúmeras vertentes ideológicas, com diferentes requintes, cores e sabores. Ao falar desse tema, surge em minha mente a imagem de uma bela ópera, La Traviata, de Giuseppe Verdi, em que, eu e minha esposa, nos deliciamos com o desenrolar da peça, em seus diferentes atos. Nela, Verdi relata, a meu ver, como as posições ideológicas da França daqueles idos foi capaz de influenciar diferentes vidas e marcar, tragicamente, o desfecho de narrativas individuais.

Introduzo essa sessão de minha análise citando La Traviata, de 1852, pois entendo que esta se relaciona com as narrativas de vida dos navegantes nesta nau que viajamos, o leitor e eu. Os imigrantes bolivianos em São Paulo, tem suas histórias de vida marcadas por ideologias que, em alguns casos, podem influenciar negativa e/ou tragicamente sua estada no Brasil. Portanto, espero, com a análise de suas narrativas escritas e visuais, amparadas por fotos e um vídeo que remete à sua terra natal, desvelar algumas ideologias submersas. Objetivo, assim, considerar as perguntas dois e três de minhas hipóteses de pesquisa.

Não me aterei aqui a uma discussão histórico-filosófico-hermenêutica do termo ideologia. Antes, assumo ideologia a partir duma concepção marxista e engelsiana, e apurada por Thompson (2002a), quando ele discute, a partir de um cunho mais crítico, as diferenças entre formas concretas e abstratas. Seu foco principal são as ideologias sustentadas por relações de dominação, simbólicas ou não. Ideologias que se fazem presentes na produção, reprodução, resistência e dominação que acarretam em desigualdades sociais. Pensando numa 
definição mais didática, o autor diz que ideologias se referem "às inter-relações entre sentido (significado) e poder", ou seja, "Ideologia é o sentido a serviço do poder” (1995, p. 16).

Voltarei a considerar esse tema em outro momento desta sessão. Por ora, gostaria de considerar brevemente, com o leitor amigo, em que se funda meu entendimento de discurso.

Penso, inicialmente, no equívoco saussuriano quando, em seus estudos, Sausurre (2003) atribui à língua uma ação pessoal e individual a ser ignorada em estudos da língua(gem) e, portanto, desvinculada de seu caráter ideológico. Esse visão foi contraposta por estudiosos, iniciando com Bakhtin (2000), que destacaram, à posteriori, o viés social, interacionista, polifônico, dialógico e, acrescento eu, dialético em alguns momentos, dos discursos que circulam na sociedade. Esta última concepção possibilita que sejam analisadas marcas das lutas socioideológicas que são travadas em busca do poder de influenciar os atores sociais em suas escolhas linguísticas, em detrimento de outras.

Foucault (1969) complementa o conceito que apresentei no parágrafo anterior, ao destacar que determinados saberes, em discursos qualificados como sendo verdadeiros e absolutos, acabam por interditar e desqualificar outros saberes, tidos como menos relevantes. Tal proposta investigativa foucaultiana estabelece a relação entre discurso-poder-sociedade, ou seja, tal tríade faz com que as relações na sociedade seja construídas, desconstruídas e reconstruídas, num círculo dinâmico e intermitente, envolvendo saberes e indivíduos em diferentes dimensões e de modo (inter)dependente.

A partir do acima, nos encontramos com a obra de Norman Fairclough, um dos mentores da Análise de Discurso Crítica. Para ele (2001), o discurso é (des)constituído na/ pela língua(gem) como forma de prática social, e não como mera atividade pessoal e individual segundo as proposições saussurianas. Ao definir o termo discurso, lemos:

Discurso contribui para a constituição de todas as dimensões da estrutura social que, direta ou indiretamente, o moldam e o restringem: suas próprias normas e convenções, como também relações, identidades e instituições que lhe são subjacentes. O discurso é uma prática não apenas de representação do mundo, mas de significação do mundo, constituindo e construindo o mundo em significado (FAIRCLOUGH, 2001, p. 91).

Partindo do pressuposto acima, entendo que o discurso alude a práticas ideológicas, ou seja, nas relações entre as pessoas na sociedade há luta por poder, pelo discurso que domina, o ideológico. É, neste sentido, que vejo as considerações sobre ideologia, como parte do 
arcabouço teórico da Análise de Discurso Crítica, como relevante para minhas análises, pois meu ponto de partida são as desigualdades a que são submetidos os imigrantes bolivianos em São Paulo através de discursos, que são sutilmente, naturalizados e que cristalizam-se como universais e verdadeiros e, como estes, afetam a inclusão social de tais imigrantes.

Posto o acima, quero retomar com o leitor amigo, a proposta de Thompson (1995) sobre a maneira como as ideologias são operacionalizadas nos discursos que circulam na sociedade. Inicialmente, o autor destaca que "estudar ideologia é estudar as maneiras como o sentido serve para estabelecer e sustentar relações de poder" (p. 76), e como tais sentidos, se inserem e circulam em distintos contextos sociais, materializados em formas simbólicas como, "ações e falas, imagens e textos, que são produzidos por sujeitos e reconhecidos por eles e outros como construtos significativos" (p. 79), conferindo diferentes graus de poder a diferentes indivíduos, ou grupos de indivíduos em dado tecido social.

Assim, para entender como o sentido serve para estabelecer e sustentar relações de poder, o autor lança mão de categorias que se prestam a analisar como tais ideologias emaranhadas na teia que compõe determinado contexto social são operacionalizadas. Procuro sintetizar na tabela abaixo, emprestada do próprio autor, os modos de operação das ideologias.

Tabela 6 - Modos de operacionalização ideológica

\begin{tabular}{|c|c|c|c|}
\hline Modo & Proposta & Estratégia & Natureza \\
\hline \multirow{3}{*}{ Legitimação } & \multirow{3}{*}{ Dominar } & Racionalização & Sustentar conceitos ideológicos \\
\hline & & Universalização & (Com)partilhar interesses \\
\hline & & Narrativização & Reproduzir o/um passado imutável \\
\hline \multirow{3}{*}{ Dissimulação } & \multirow{3}{*}{ Ocultar } & Deslocamento & Mudar conotações e sentidos \\
\hline & & Eufemização & Positivar ações e relações \\
\hline & & Tropo & Atribuir linguagem figurada ao poder \\
\hline \multirow{2}{*}{ Unificação } & \multirow{2}{*}{ Unir identidades } & Padronização & Propiciar um referencial unificado \\
\hline & & Simbolização & Construir uma identidade coletiva \\
\hline \multirow{2}{*}{ Fragmentação } & \multirow{2}{*}{ Segmentar ameaça } & Diferenciação & Usar a diferença visando a desunião \\
\hline & & Expurgo & Constituir um inimigo comum \\
\hline
\end{tabular}




\begin{tabular}{|l|l|l|l|}
\hline \multirow{2}{*}{ Reificação } & Eliminar a história & Naturalização & Tornar inevitável a criação histórica \\
\cline { 3 - 4 } & Eternalização & Imutabilizar fenômenos históricos \\
\cline { 2 - 4 } & Nominalização & Transformar ações em nomes \\
\hline
\end{tabular}

Fonte: Thompson (1995, p. 80-89)

Ao resumir o conceito thompsoniano de ideologias, lemos:

\begin{abstract}
A categoria de Ideologia, para Thompson, procura chamar a atenção para as maneiras como o sentido é mobilizado a serviço dos indivíduos e grupos dominantes, isto é, as maneiras como o sentido é construído e transmitido pelas formas simbólicas e serve, em circunstâncias particulares, para estabelecer e sustentar relações sociais estruturadas no jogo do poder, do dominado e do dominante, onde uns buscam preservar e outros procuram contestar (PUHL, 2003, p. 8).
\end{abstract}

Portanto, como destaca a autora na citação acima, há um jogo de poder que se estrutura a partir da relação entre os atores que protagonizam certo contexto sociohistórico.

Fairclough (2001) ressalta, ainda, que é possível que os indivíduos, em determinado contexto social, não sejam capazes de perceber as ideologias que subjazem sua prática discursiva, o que os impede de identificar, resistir e superar relações de dominação em tal contexto; o que, em última instância, afetar(ia) ações afirmativas de caráter socioinclusivo, visto que elas passariam a ser influenciadas por (pre)conceitos ideológicos e historicamente construídos. E, Thompson, acrescenta, que esse jogo ideológico se estabelece em relações que se constituem em instituições sociais, que funcionam como um conjunto de regras e recursos relativamente estáveis. Adicionalmente, esclarece que tais:

instituições [ou relações] sociais reconstroem conjuntos de regras, recursos e relações que as constituem, [e que] analisá-las implica traçar seu desenvolvimento através do tempo e examinar as práticas e atitudes das pessoas que agem a seu favor e dentro delas (THOMPSON, 1995, p. 367).

Passo agora a apresentar as narrativas escritas dos imigrantes bolivianos, ou navegantes nesta nau. Para estimulá-los a relatar parte de sua histórias de vida, apresentei, aos participantes do grupo focal, um conjunto de fotos, em forma de slides, que representam sua 
terra natal, a Bolívia. Pedi que fizessem comentários breves ${ }^{30}$ sobre as fotos para, em seguida, escreverem livremente sobre o que considerassem relevante de sua história de vida. Apresento abaixo um mosaico que agrupam as fotos utilizadas nesse momento das atividades.

Figura 4 - Fotos representativas da Bolívia ${ }^{31}$

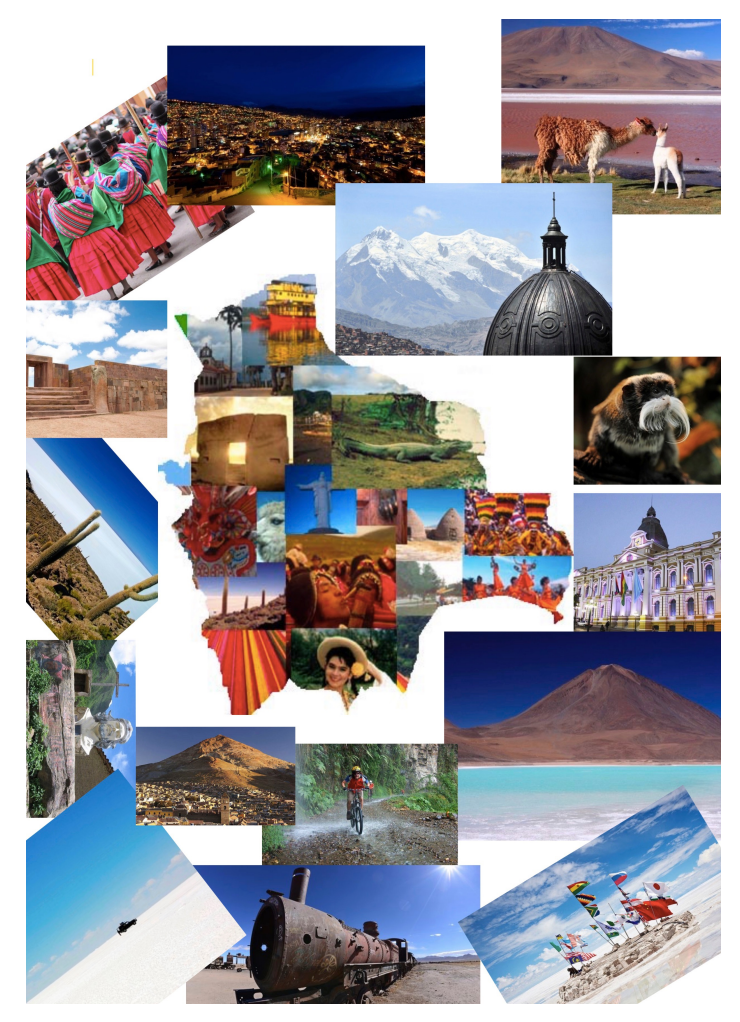

Fonte: Mosaico elaborado pelo autor (2015)

Dentre as categorias analíticas propostas por Thompson (1995) que se prestam à análise e identificação das ideologias em dado contexto sociohistórico, ressalto que não considerarei em detalhes cada uma delas. Antes, apresentarei aquelas que emergiram das narrativas escritas dos participantes da pesquisa. Com isso, pretendo demonstrar se, de fato, ocorre a inclusão social dos imigrantes bolivianos nesse processo de imigração.

Ao falar de legitimação de ideologias, entendo que esta se relaciona com conceitos e, por que não dizer alguns pre-conceitos, aceitos em dado tecido societal. Veja, nos fragmentos abaixo, como tal legitimação ocorre no caso dos imigrantes bolivianos em São Paulo:

\footnotetext{
${ }^{30}$ Tais comentários foram incluídos no bojo do texto de suas narrativas escritas.

${ }^{31}$ Disponível: http://viajeaqui.abril.com.br/paises/bolivia/fotos. Acessado em 02 de janeiro de 2015.
} 
Excerto $1^{32}$ — Legitimação por universalização: Juan ${ }^{33}$

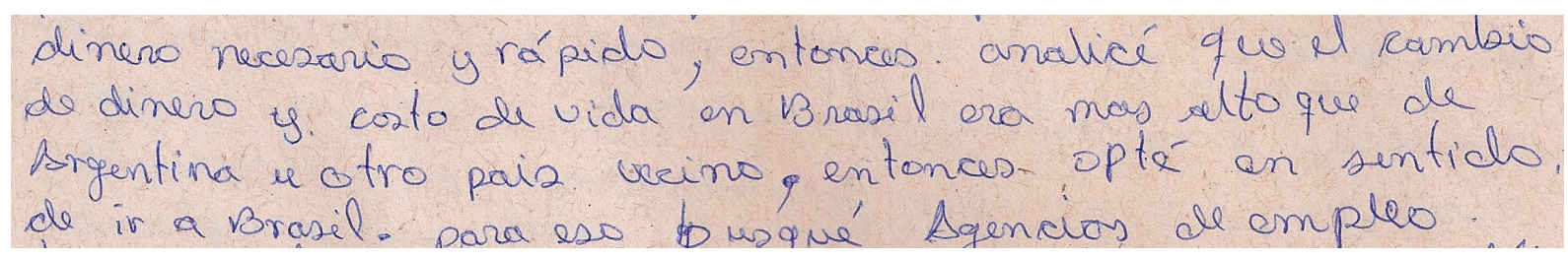

Note que neste excerto, Juan, legitima a ideologia vigente que ocorre por meio da universalização, ou seja, para ele, vir para o Brasil resultaria em benefício para ele, assim como resultou para outros bolivianos que já haviam imigrado. Para os imigrantes bolivianos em São Paulo, imigrar para o Brasil resulta em bem comum, em interesses compartilhados, pois o país oferece melhores condições socioeconômicas e políticas que o seu país de origem.

Nos excertos a seguir, veremos que essa legitimação ideológica ocorre também por meio de narrativização, ou seja, as histórias de vida dos imigrantes bolivianos se relacionam com o seu passado na Bolívia, mas, agora, eles fazem de um presente aceitável, ainda que não seja o desejado antes de decidirem imigrar para o eldorado no Brasil.

Excerto 2 - Legitimação por narrativização: Juan ${ }^{34}$

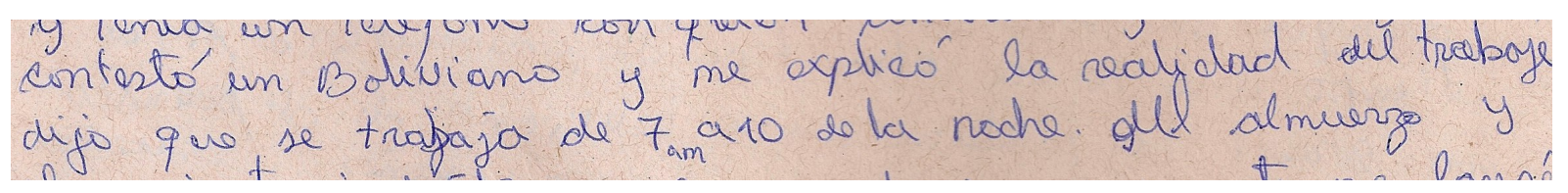

\footnotetext{
32 Todas as traduções dos excerto foram feitas por mim de forma livre e de modo a propiciar a plena compreensão do que queria exprimir o participante. Justifico tal liberdade por estar presente no momento da produção do texto e acompanhar o uso dos recursos metalinguísticos que ampliam o escopo do que se quer dizer.

33 "analisei como o cambio da moeda e o custo de vida no Brasil eram mais altos que na Argentina ou outros países vizinhos. Assim, optei por vir para o Brasil”.

34 "atendeu [o telefone] um boliviano que me explicou a realidade do trabalho [aqui no Brasil] e disse que se trabalha de 7 às $22 \mathrm{~h}$ "
} 
Excerto 3 - Legitimação por narrativização: Carolina 35

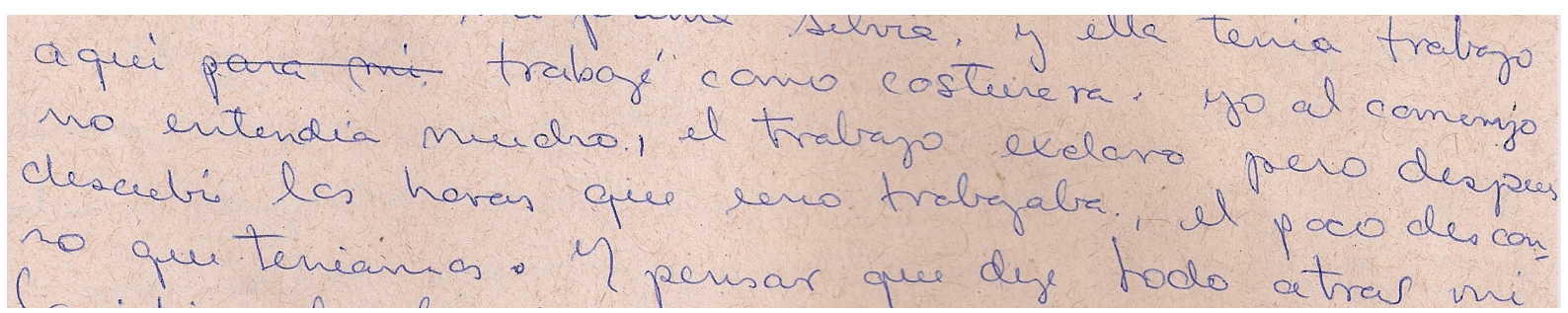

Excerto 4 — Legitimação por narrativização: José

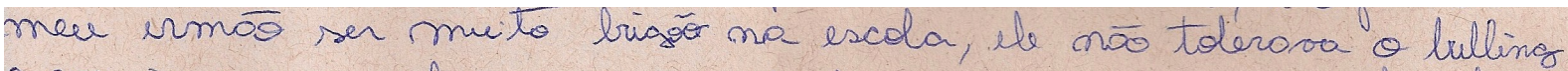
e por usso se envolvia em muetios bligas, ate mesmo na crechê ,li.

Excerto 5 - Legitimação por narrativização: Pedro 36

no consegiuan, todo estaba parado. Con la ayuda de mi
prima yina a Brasil, aqui habia trabzjo pero el salario para
un inicia nte era demasiado bajo. y mi decepción aumentaba.

Excerto 6 - Legitimação por narrativização: Mariana

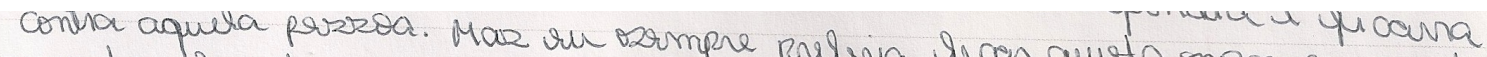
quando eltes tocasnom no cossunto por quria fican quista no meu cantre ramprermente abouxarna a cabrea u dormia não qurria brigoos, untaur ru qui labarram.

Em cada um dos excertos acima, destaco como os conceitos ideológicos a que são submetidos os bolivianos indicam que não há inclusão social, de fato. Essa asserção é legitimada pela narrativização de sua histórias. Todos destacam que não há como mudar o passado. Juan observa: "se trabalha de 7 às 22h"; Carolina alerta: "trabalho escravo (...) pouco descanso"; José, ao falar do seu irmão, diz: "ele não tolerava o bullying e, por isso se

\footnotetext{
35 "trabalhei como costureira. Não entendia muito no começo [sobre] o trabalho escravo, mas depois descobri [entendi] as [muitas] horas que uma pessoa trabalhava e o pouco descanso que tínhamos."

36 “(...) vim para o Brasil e aqui havia trabalho, mas o salário para um iniciante era muito baixo; e minha decepção aumentava."
} 
envolvia em brigas"; Pedro lamenta: "o salário para um iniciante era muito baixo ${ }^{37}$; e minha decepção aumentava." e, por fim, Mariana nos informa: "preferia ficar quieta, no meu canto (...) não queria brigas, abaixava a cabeça e dormia e não prestava atenção no que falavam”.

Os excertos acima e os destaques que dou a alguns trechos deles, servem para ilustrar a situação dos imigrantes bolivianos em São Paulo. Para Juan, Carolina e Pedro, o problema reside em questões trabalhistas e, José e Mariana relatam situações envolvendo acosso na escola. Igualmente, indicam, de maneira gráfica, como eles continuam vivenciando os mesmos problemas neste bairro paulistano embora, aparentemente, muitos não consigam enxergar como são afetados (FAIRCLOUGH, 2001). Na perspectiva thompsoniana, esse processo de legitimação de ideologias através da narrativização deve ser exposto para que tais ideologias, que perpetuam desigualdades, sejam eliminadas visando ao benefícios dos dominados, afetados negativamente por elas.

Notemos, ainda, que, nos excertos acima, não há marcas de que eles tenham sido beneficiados por algum processo socioinclusivo afirmativo. Vivem numa situação de apartação social (BUARQUE, 1990). Para que haja inclusão social, de fato e de direito, proteção contra a pobreza e combate a exclusão social, uma pesquisadora social escreve:

o termo [exclusão social] está longe de ser unívoco, mas vem sempre relacionado às concepções de cidadania e de integração social e é empregado para designar a forma de alijamento dos frutos da riqueza numa sociedade e do desenvolvimento econômico, particularmente dos direitos humanos (ARZABE, 2001, p. 37).

O que notamos, no caso dos imigrantes bolivianos em São Paulo, a partir do recorte nos excertos acima é que não há evidências de preocupação com a "cidadania, integração social", mas um "alijamento dos frutos da riqueza ... e dos direitos humanos", sobretudo nas questões relacionadas com dois pilares da cidadania, a saber, trabalho e educação dignos.

\footnotetext{
${ }^{37}$ A referência de Pedro é o ano de 1995/1996 quando o salário mínimo era de R \$112,00. O que pagavam, mensalmente, ao bolivianos nessa época era $\mathrm{R} \$ 35,00 \mathrm{em}$ média, ou $\mathrm{R} \$ 50,00$ na melhor das hipóteses. Ou seja, um boliviano recebia, em média, $31,25 \%$ do salário mínimo vigente no país. E, desse valor, os donos das oficinas descontavam as refeições e alojamento. No fim das contas, o que sobrava para o trabalhador boliviano não era suficiente sequer para despesas com higiene pessoal - o que explica o estereótipo de sujos e malcheirosos que marca os bolivianos no bairro. Daí, a declaração de Carolina de que o trabalho era escravo, pois com essas cifras eles tinham que trabalhar meses, e às vezes anos, para pagar a benesse de haverem sido trazidos ao Brasil pelos donos das oficinas. E, lamentavelmente, essa situação perdura até os nossos dias, com pouca variação.
} 
Outro tipo de legitimação de ideologias, segundo Thompson (op.cit), ocorre por meio da racionalização, que consiste na construção de conceitos que se prestam a dar sustentação a determinada(s) ideologia(s). Veja o excerto abaixo:

\section{Excerto 7 - Legitimação por racionalização: Carolina ${ }^{38}$}

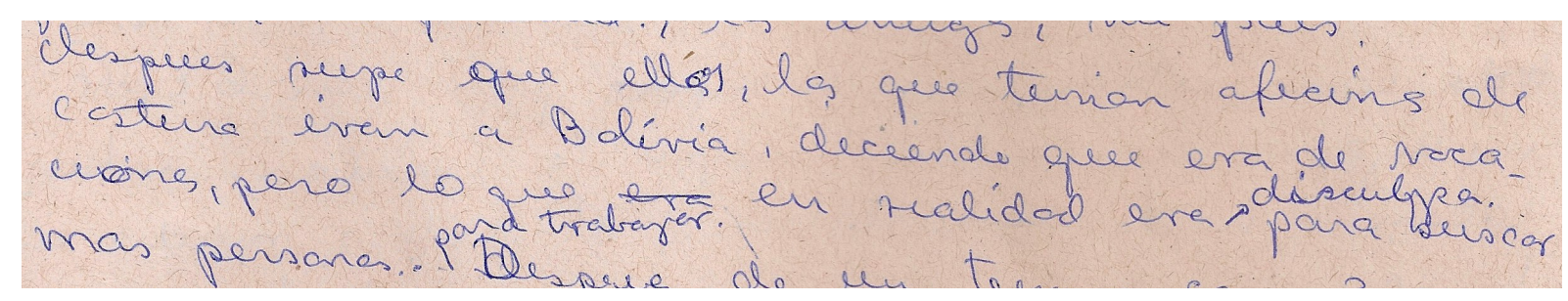

Aqui, Carolina destaca como a ideologia submersa já influenciava inclusive outros bolivianos que, talvez sem notar, serviam aos mesmos interesses ideológicos que os afeta(va) de diferentes maneiras. Numa dinâmica cíclica, esse boliviano, dono de oficina, atua socialmente como dominado e como dominador, como um "dos produtores da forma simbólica que usa uma cadeia de raciocínio para defender essa relação" ideológica (PUHL, 2003, p. 7) e institucional viabilizada por meio de "práticas e atitudes das pessoas que agem a seu favor e dentro delas" (THOMPSON, 1995, p. 367). Esse tema foi exemplificado pela informação que compartilhei, com o leitor amigo, na nota de rodapé $\mathrm{n}^{\circ} 37$.

Vale ressaltar aqui que o ciclo de exclusão é ideologicamente (re)transmitido entre dominado e dominador, ou seja, os próprios pares dos bolivianos passam a contribuir para essa cadeia de exclusão agindo de "dentro delas" (THOMPSON, 1995, p. 367). Aqui, noto o que Sarah Escorel (1999), numa tese de doutorado em Sociologia, destaca como um tipo de desumanização com face da exclusão social. A autora diz:

Embora a zona de desvinculação ocupacional e sociofamiliar não possa ser comparada a campos de concentração, a ruptura de vínculos em diversos âmbitos da condição de exclusão compartilham com experiências [diversas], com o afastamento familiar e social, caracterizadas pela marginalização (...) e dessensibilização frente ao convívio cotidiano com a miséria [imposta pela situação na vida] (ESCOREL, 1999, p. 68).

\footnotetext{
38 "depois soube que os [bolivianos] que tinham oficina viajavam para a Bolívia, dizendo que iam de férias, mas que, na verdade, isso era só uma desculpa para buscar mais pessoas para trabalhar.”
} 
O que descreve autora é o que se nota no caso dos imigrantes bolivianos e denunciado por Carolina, no excerto acima. Há um "afastamento familiar e social" e uma “dessensibilização" frente a condição do par, o que gera exclusão e exploração. Assim, o dominado se posiciona, ideológica e inconscientemente, à serviço do dominador.

Passo a considerar agora a categoria analítica que se relaciona com a dissimulação, ou seja, as "relações de dominação [são] obscurecidas de forma que se desvie a atenção e se ignorem os processos existentes" (ASSUNÇÃO, 2007, p. 66), ou seja, "as relações de poder são estabelecidas e sustentadas pelo seu ocultamento" (PUHL, 2003, p. 7). Tal dissimulação ideológica pode ocorrer por meio do deslocamento, que se refere ao ato de mudar as conotações de sentido, e através da eufemização, que visa a apagar ou disfarçar as características ruins do processo por ocultá-lo para que este se torne mais acessível e brando.

Veja alguns exemplos de dissimulação nos excertos abaixo:

Excerto 8 - Dissimulação por deslocamento: Carolina 39

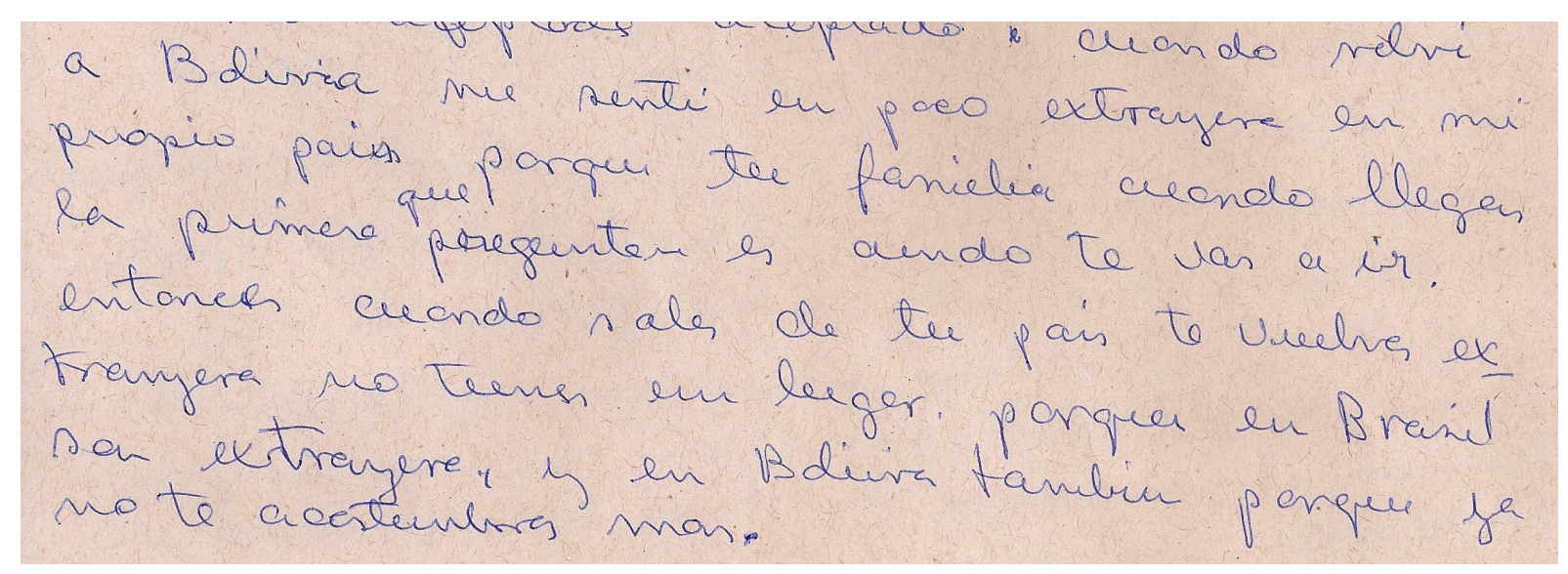

Deslocar pode significar pensar sem permitir interferência de carga(s) emotiva(s); mudar o sentido, a conotação de algo que se considerava estabelecido. Esse tipo de raciocínio esconde, por detrás, os reais motivos pelos quais os estrangeiros são (in)visibilizados e, por conseguinte, excluídos socialmente. Eles perdem a referência familiar, cultural e o sentimento de pertença à sua terra natal. E, nesse processo, passam a atribuir esse sentimento deslocado,

\footnotetext{
39 “quando voltei a Bolívia, senti-me um pouco como estrangeira no meu próprio país porque, ao chegar, a primeira coisa que minha própria família pergunta é quando vou voltar para o Brasil. Então, quando você sai de seu país volta a sentir-se como estrangeiro por não ter um lugar fixo. No Brasil, sou estrangeira e, na Bolívia, também porque não me acostumo mais."
} 
ou a culpa pelo acontecimento, a si mesmos. Ou seja, eles optaram por imigrar; logo, precisam aprender a lidar com esse sentimento de ausência de pertença, constante estranhamento geo-afetivo. Trata-se, interessantemente, de um processo de auto-exclusão ou culpabilização. Em outras palavras, o imigrante, neste estágio, torna-se vulnerável social e emocionalmente. Sobre isso, note o que diz Giuliana Franco Leal:

Ao se pensar a exclusão social como quebra e principalmente fragilização de laços sociais, o que está em questão são sobretudo processos. Nesses processos, as pessoas, famílias e/ou grupos sofrem vulnerabilização, isto é, vão se tornando mais frágeis diante dos riscos de descensão e isolamento social, e cada vulnerabilidade as torna mais suscetíveis a novas outras (LEAL, 2011, p. 127).

É interessante como a fala da citação acima, revela a situação de vulnerabilidade de Carolina, no excerto acima, pois ela se sente deslocada, excluída em seu “próprio país”. Esse sentimento a torna mais suscetível a novas formas de vulnerabilidade, como salienta a autora acima. Em outro trecho de sua narrativa escrita, Carolina mostra essa vulnerabilidade ao falar do sentimento de impotência ao ver seu filho sendo excluído e sofrendo acosso na escola ${ }^{40}$. Todo esse processo a que Carolina e seu filho são submetidos certamente não demonstra qualquer tipo de inclusão social, ou sequer de integração e aceitação plena na comunidade.

Apresentarei agora alguns exemplos de dissimulação por eufemização.

Excerto 9 - Dissimulação por eufemização: Mariana

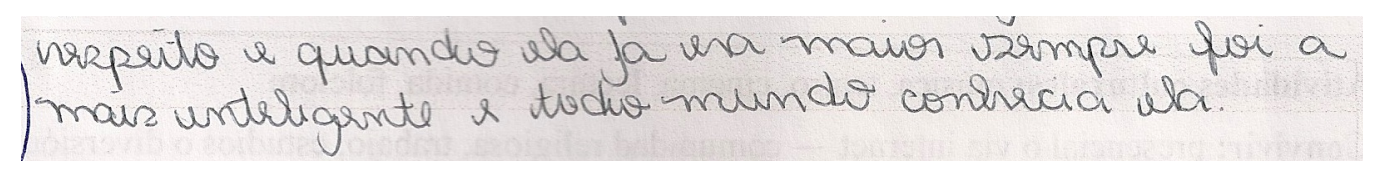

\footnotetext{
40 "não deixamos de ser estrangeiros e nossos filhos, mesmo os nascidos aqui, são tratados como estrangeiros. É o que aconteceu com XX, meu filho. Na escola sempre o isolavam, o xingavam e, até, o agrediam. Ele sofreu muito na escola." (Este trecho de sua narrativa não aparece, ou é analisado, como excerto no bojo desse texto).
} 
Excerto 10 - Dissimulação por eufemização: Juan ${ }^{41}$

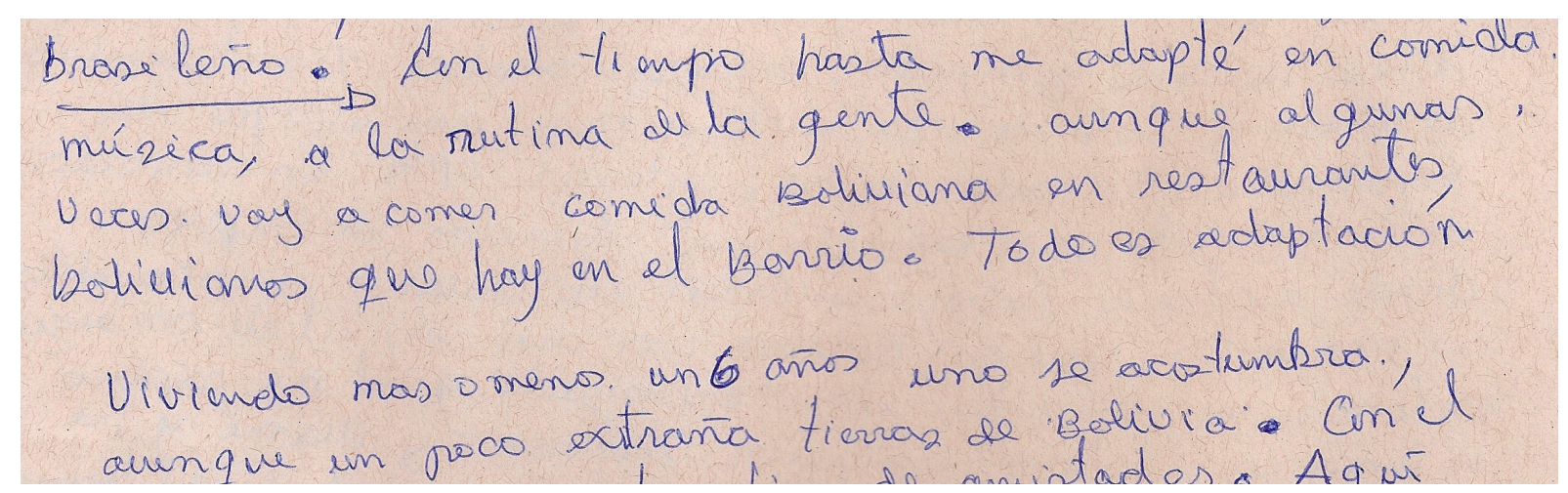

Excerto 11 - Dissimulação por eufemização: Carolina ${ }^{42}$

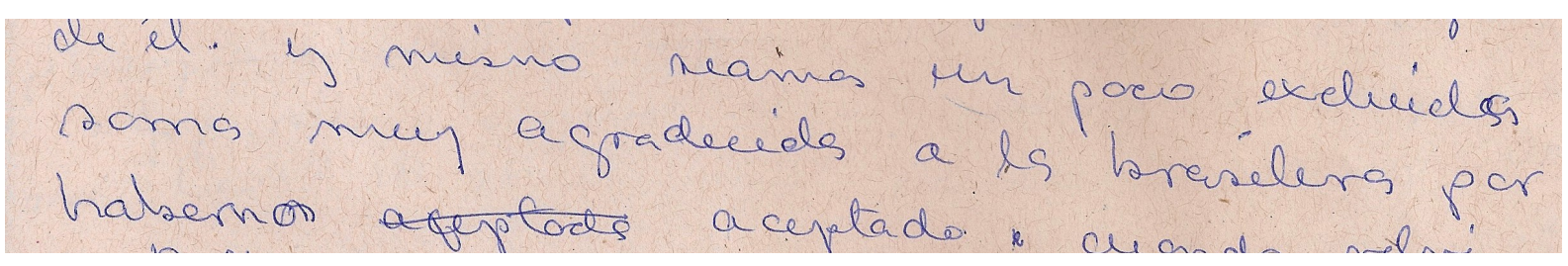

Excerto 12 - Dissimulação por eufemização: Pedro 43

Senti qua tos brasileros son más acogedores, a resar de tanta volencia que ya excstia en aquallos años $(94-96)$. De este

O propósito da dissimulação ideológica por eufemização é ocultar ideologias que promovem a desigualdade por desfocar, obscurecer ou ocultar discursos de dominação. Consegue-se isso quando o dominado passa a atenuar e suavizar, conscientemente ou não, as ações opressivas que o incomodam, mas que são abrandadas para fins de sobrevivência. Isso ocorre no caso dos imigrantes bolivianos, pois, por não estarem plenamente cientes do

\footnotetext{
41 “com o tempo, até consegui me adaptar com a comida, a música e a rotina das pessoas; embora, algumas vezes, vou comer comida boliviana em restaurantes bolivianos do bairro. Tudo é adaptação. Mas, vivendo uns por um seis anos aqui, você se acostuma; embora, sinta um pouco de saudade das terras da Bolívia.”

42 “e, mesmo que sejamos um pouco excluídos, somos muito agradecidos aos brasileiros por terem nos recebido e aceito."

43 “senti que os brasileiros são mais acolhedores, apesar de [haver] tanta violência naqueles anos."
} 
processo de exclusão a que são submetidos, não percebem que precisam recuperar o sentimento de pertença e integração, perdidos com a imigração.

No excertos acima, Mariana revela que sua irmã, assediada na escola por ser boliviana e ter dificuldades com a língua portuguesa, introvertidamente estudava muito a ponto de se tornar a "mais inteligente" e, assim, conseguiu fazer com que todo mundo "conhecesse ela" e a "respeitasse". Aqui, Mariana suaviza, abranda a opressão e, sem se dar conta, trata de compensá-la, na figura da irmã, sendo a mais inteligente para ser respeitada e conhecida. $\mathrm{Ou}$ seja, a irmã e a própria Mariana entendiam que para ser incluídas na escola e na comunidade, elas precisavam oferecer algum diferencial que compensasse o ser bolivianas.

No caso de Juan, percebo a regularidade e a frequente modalização. Ele usa termos como: "com o tempo", "até consegui", "embora, algumas vezes", "tudo", "você se acostuma", "sinta um pouco". Nessa dimensão gramatical, Juan modaliza sua fala, seja pelo uso de itens gramaticais específicos, seja pela entonação ou hesitação. Halliday (2004) e Fairclough (2003) abordam esse tema da modalização discursiva ao destacarem que ela indica que o falante se compromete com o que diz, o que é muito relevante aqui, pois indica a preocupação de Juan com o ser incluído na comunidade local, o ser aceito. A fala de Juan indica seu esforço em adaptar-se, acostumar-se com a comida, a música e a rotina dos brasileiros.

Carolina, também modaliza: "um pouco", "muito". Mas, o faz para eufemizar a sua relação com o Brasil, embora se sinta excluída é agradecida. Essa postura é a que se implanta no subconsciente dos imigrantes bolivianos em São Paulo. Eles devem sentir-se agradecidos, embora sofram ações de exclusão sociais, pois o país os recebeu, os acolheu, pelo menos do ponto de vista político. Com essa eufemização, oculta-se o fato real, a saber, a exclusão como imigrantes. Pedro faz o mesmo ao dizer que os brasileiros são mais acolhedores, "apesar de haver tanta violência”. Ele faz aqui alusão à violência contra os bolivianos, seja essa emocional, verbal e, até mesmo, física.

Esse processo de eufemização, destacado nos excertos acima, resulta da incapacidade política de agir dos imigrantes bolivianos dada a sua exclusão social, privação de cidadania, isolamento e desenraizamento. Sobre isso, Hannah Arendt diz que "não ter raízes significa não ter no mundo um lugar reconhecido e garantido pelos outros; ser supérfluo significa não pertencer ao mundo de forma alguma" (ARENDT, 1979, p. 243). É, a partir desse sentimento, que decorrem discursos eufemizados, em busca de aceitação social. 
Até este ponto, procurei demonstrar através de fragmentos das narrativas escritas, como as ideologias de dominação dos imigrantes bolivianos em São Paulo operam em favor da desigualdade, como elas se organizam e afetam a percepção de inclusão social a que deveriam ser beneficiados os imigrantes bolivianos em São Paulo.

A partir de agora, seguirei com a análise dos outros três modos de operação ideológica, valendo-me das narrativas visuais de tais imigrantes. Para tanto, iniciei os trabalhos mostrando aos participantes um videoclipe intitulado "Bolivia te Espera", que destaca alguns dos pontos turísticos, e que são representativos da cultura do seu país.

Figura 5 - Foto do videoclipe ${ }^{44}$

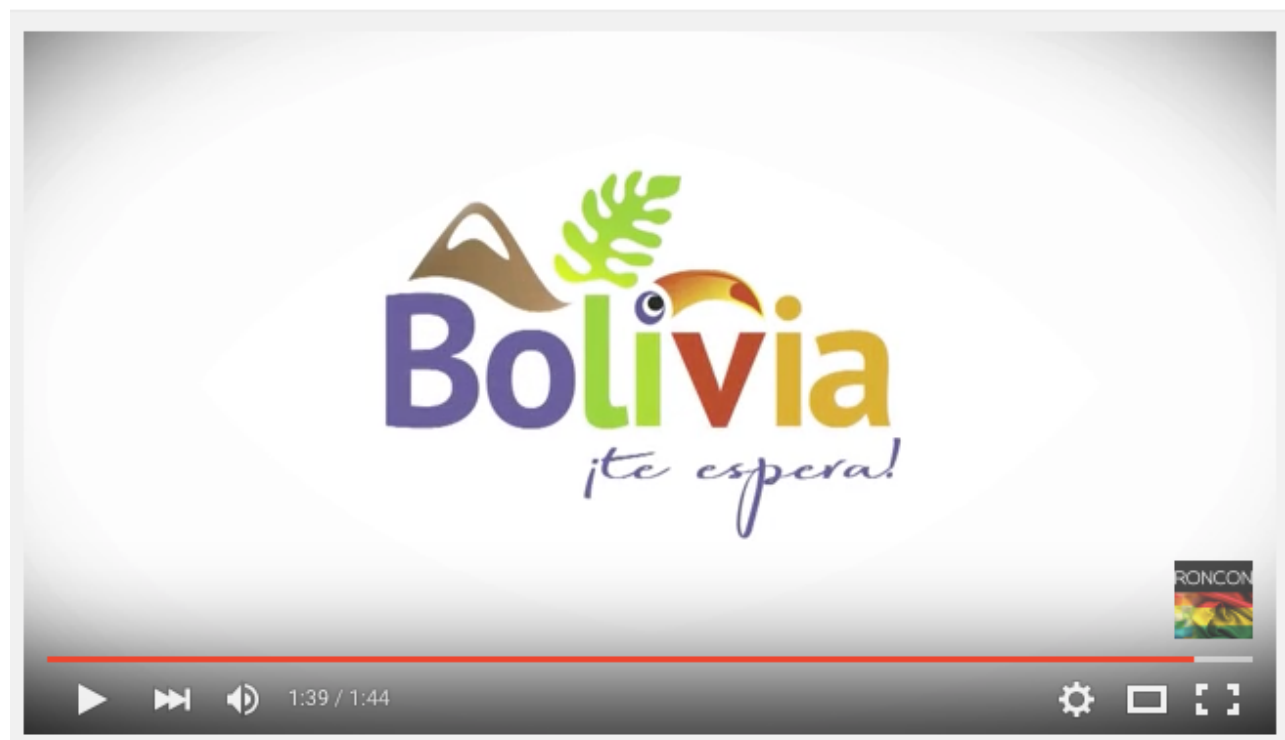

Após o vídeo, pedi que inserissem em sua narrativa escrita suas impressões do vídeo e a relação com sua história de vida como imigrante. Alisto a seguir os trechos das narrativas escritas com comentários relacionados ao vídeo bem como as narrativas visuais.

\footnotetext{
${ }^{44}$ Disponível: http://www.youtube.com/watch?v=3oDyrqlRBs0. Acessado em 02 de janeiro de 2015.
} 
Excerto 13 - Unificação por padronização: Mariana

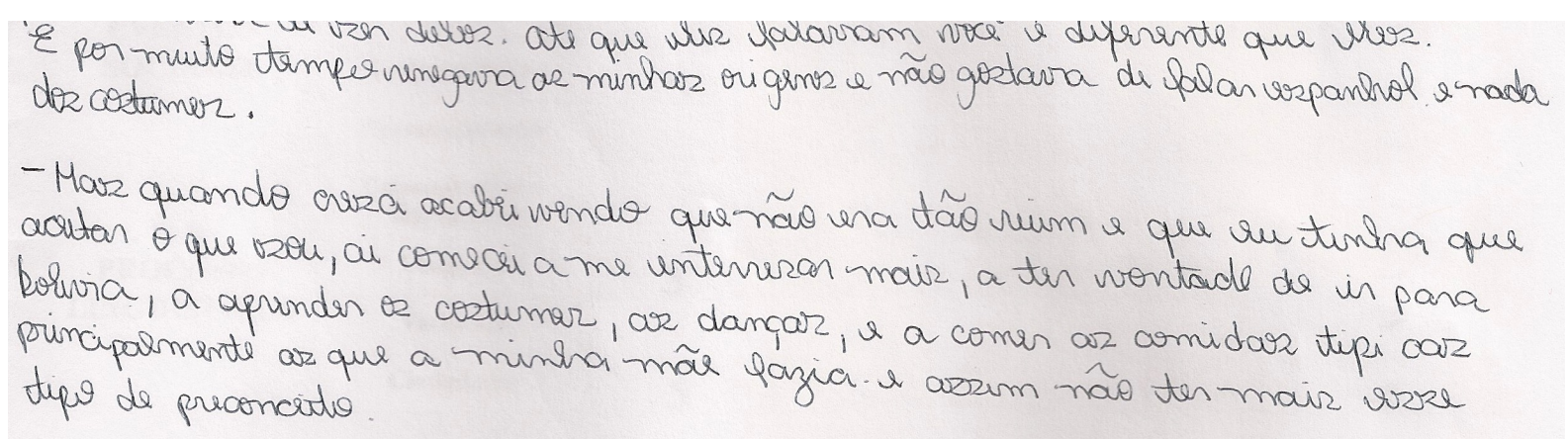

Neste excerto, Mariana mostra um movimento duplo de unificação ideológica por padronização, que tem por objetivo criar um padrão aceito por todos os membros de determinada comunidade ou contexto social. Inicialmente, Mariana quer ajustar-se ao padrão brasileiro de ser: "renegava ${ }^{45}$ minhas origens, e não gostava de falar Espanhol e nada dos costumes." Entretanto, a dinâmica de sua fala muda quando ela 'cresce': "acabei vendo que não era tão ruim", "tinha que aceitar o que sou", "me interessei mais" e "não ter mais esse tipo de preconceito". Veja como Mariana reflete o acima em sua narrativa visual:

Figura 6 - Narrativa visual: Mariana

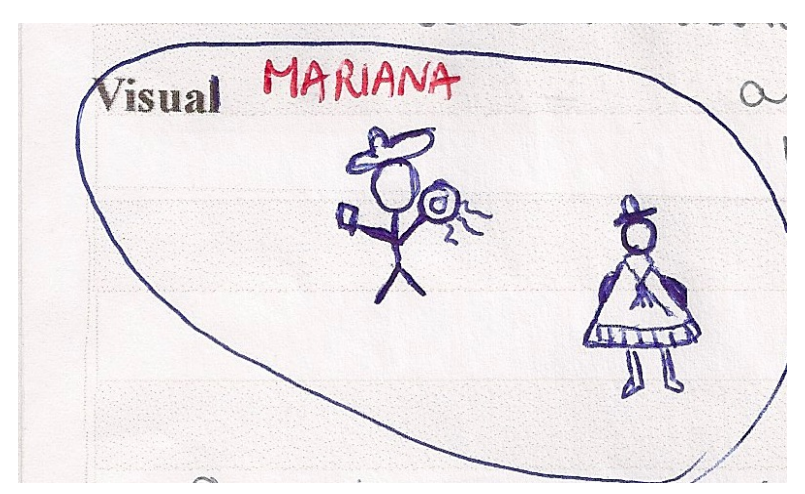

\footnotetext{
${ }^{45}$ É interessante o uso desta palavra que, embora exista em Português, é pouco usada em contextos informais de conversação. Entretanto, em Espanhol essa palavra tem uma carga semântica bastante forte em contextos informais, pois significa que a pessoa abomina, despreza totalmente a alguém ou alguma coisa, chegando a ter até certo tipo de repulsa e nojo. Mariana, usa aqui uma palavra em Espanhol, consciente ou não da força semântica do léxico em uma e na outra língua, para indicar seu ponto de vista em relação ao assunto que aborda.
} 
É interessante como Mariana, agora mais velha e influenciada pela força da comunidade boliviana no bairro, continua presa a essa ou aquela vertente ideológica que direciona o imigrante boliviano para um ou outro padrão de unificação, um referencial único.

Vale ressaltar que o comentário e a narrativa visual de Mariana vieram à tona após assistir ao vídeo, o que demonstra seu anseio de sentir-se incluída quer em uma cultura, a boliviana, quer em outra, a brasileira. Por um lado, ela é brasileira, mas não se sente confortável ao perceber todo o processo de exclusão vivido por ela e sua irmã. Por outro lado, quer buscar 'nas suas origens' um referencial sociohistórico e cultural para que possa cimentar seu sentimento de pertença, perdido entre duas nacionalidades: a de nascimento e a dos pais. Essa busca por aceitação de Mariana, é reflexo de seu sentimento de exclusão. A concepção da exclusão social de Tosta (2003) se alinha às narrativas de Mariana:

Pode-se, então, apreender como ponto diferenciador da concepção a sua dimensão simbólica: a exclusão é um processo de ruptura do vínculo social, além da ruptura simbólica das representações que lhes são comuns. $\mathrm{O}$ indivíduo excluído não é simplesmente o rejeitado física, geográfica ou materialmente, ele não apenas é excluído da troca material e simbólica, como também ocupa um espaço negativo na representação social dominante (TOSTA, 2003, p. 204).

Alinhavando a citação acima com as narrativas de Mariana, noto que ela busca ser incluída socialmente, não importa em que país - Brasil ou Bolívia. Ela não quer continuar "ocupando um espaço negativo na representação social", ou seja, ela quer ser incluída, aceita e poder usufruir do vínculo social que liga o indivíduo à sociedade. Entretanto, lamentavelmente, ela acaba por ser tragada por outro processo, o ideológico, ao buscar o que Thompson (2002a) chama de operacionalização ideológica de unificação por padronização.

Abordarei agora a operacionalização ideológica pelo modo de fragmentação.

\section{Excerto 14 - Fragmentação por expurgo: Juan 46}

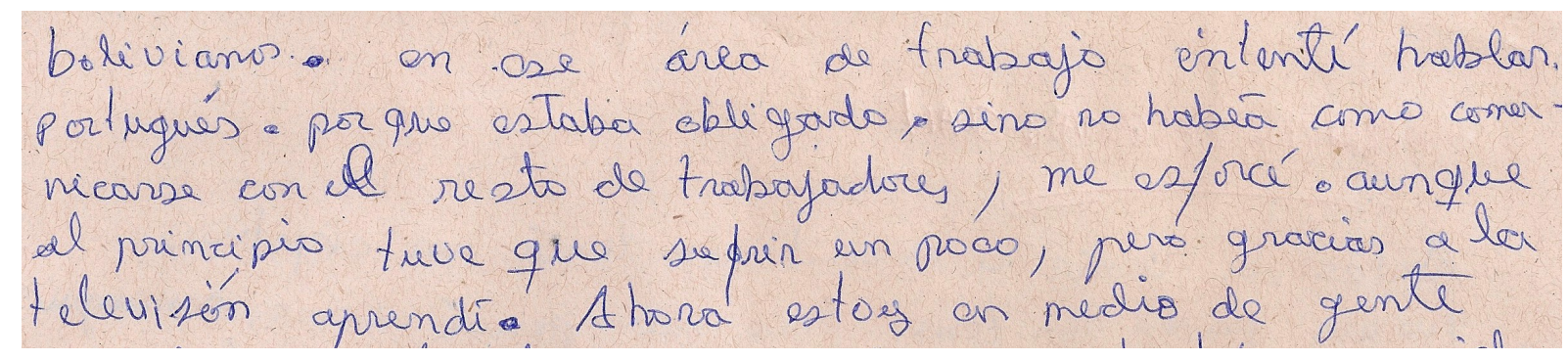

46 “nesse trabalho, aprendi a falar Português porque era obrigado, caso contrário, não havia como comunicar-me com os demais trabalhadores. Esforcei-me, embora no começo, tivesse que sofrer um pouco. Mas, aprendi graças a televisão. 
Aqui, Juan mostra como a língua portuguesa era considerada um inimigo, pois "foi obrigado" a aprendê-la para poder se comunicar no trabalho. Esse modo ideológico se relaciona com a quebra de unidade social, ou seja, pela exclusão da língua materna, Juan começa a perder o seu sentimento de pertença de ser incluído em seu grupo social original, o que, para ele, implicava "sofrer um pouco". Novamente, vemos aqui a questão da modalização, "um pouco", que nada mais é que uma forma eufemística de tentar atenuar a dor, abrandar o caráter ideológico de sua narrativa de vida, de sua história como imigrante.

Veja como a narrativa visual de Juan reflete ambiguidade, pois, por um lado, ele quer voltar ao seu país, mas, por outro, sente que ainda não atingiu o objetivo de imigrar.

Figura 7 - Narrativa visual: Juan

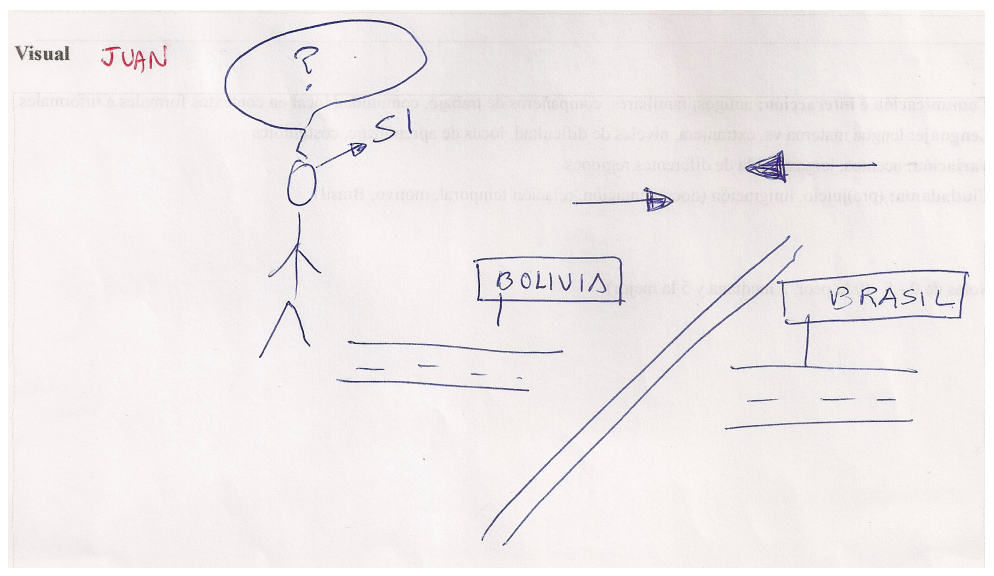

Após assistir ao vídeo, Juan posiciona-se do lado boliviano da fronteira. Mas, estando na Bolívia tem dúvida quanto a se deve vir novamente para o Brasil, enquanto, estando no Brasil, apenas pensa em voltar para sua terra natal. Essa postura reflete seu sentimento de querer sentir-se incluído no Brasil; de querer ter direito à cidadania, que está atrelada ao conceito de inclusão social. Para Schwartzman e Reis (2005), a inclusão social cidadã "se refere ao direito de participar da sociedade e usufruir benefícios considerados essenciais (p. 151). O desenho de Juan mostra que ele não se sente assim, pois ele está posicionado no lado da Bolívia, onde tem seus direitos como cidadão assegurados, muito embora a dúvida de vir/ estar/continuar no Brasil persiste. 
Apresentarei agora a questão da fragmentação pela diferença.

Excerto 15 - Fragmentação pela diferença: Pedro 47

Sentimos prejuicio, pere no dar mucha importancia prefefermos estar en nuestro canto, estamos concientes de que somos ax tranferos.

Para Pedro, ser estrangeiro é um problema que gera preconceito e, que como imigrante, ele precisa estar conformado, evitar embates, "não dar muita importância", ilhar-se da sociedade ficando "no seu canto", excluído. Essa postura, ideologicamente adotada por Pedro, e que reflete a da maioria dos bolivianos em São Paulo, realça a questão da fragmentação, segmentação do grupo que pode ameaçar a relação de poder socialmente instituído em uma comunidade, marcando a diferença entre o local e estar "conscientes de que somos estrangeiros" e, portanto, não podemos interferir na ordem discursiva estabelecida.

Veja como Pedro enfatiza essa ideia em sua narrativa visual.

Figura 8 - Narrativa visual: Pedro

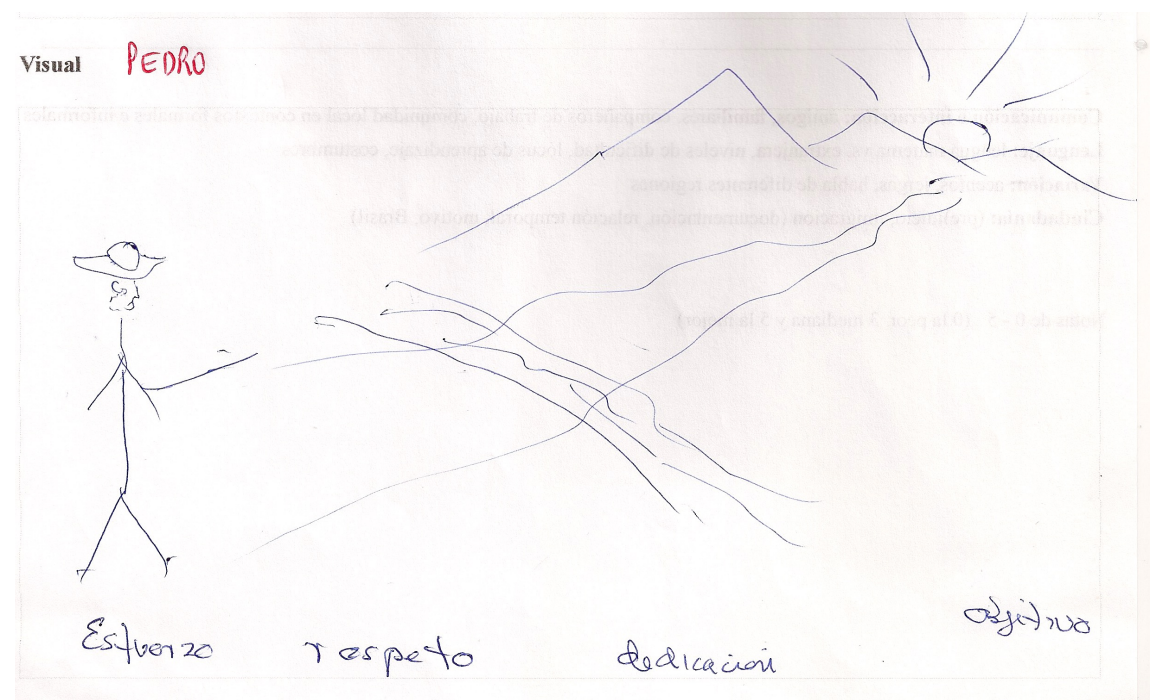

47 “sentimos o preconceito, [mas] para não dar muita importância preferimos estar em nosso canto, estamos conscientes de que somos estrangeiros." 
As palavras que Pedro usa em sua narrativa visual, refletem sua preocupação de "estar em nosso canto ... [pois] somos estrangeiros". Parece-me que Pedro quer ser invisibilizado, não quer incomodar para não ser incomodado. Fez-me lembrar das palavras que alisto abaixo:

E como são cada vez menos vistos, como alguns os querem ainda mais apagados, riscados, escamoteados dessa sociedade, eles são chamados de excluídos. Mas, ao contrário, eles estão lá, apertados, encarcerados, incluídos até a medula! Eles são absorvidos, devorados, relegados para sempre, deportados, repudiados, banidos, submissos e decaídos mas tão incômodos: uns chatos! Jamais completamente, não jamais suficientemente expulsos! Incluídos, demasiado incluídos, e em descrédito! (FORRESTER, 1997, p. 15).

Numa quase linguagem poética, o autor mostra que, o anseio de Pedro, é pouco possível; são “excluídos”, mas “eles estão lá (...) tão incômodos”. São (in)visíveis!

No entanto, para Pedro, e sua família, terem a paz como objetivo - refletida pelo sentimento bucólico da imagem que ele desenhou - eles precisam de esforço e dedicação em um movimento de respeito duplo, mas que ele destaca, mais especificamente, do imigrante boliviano em relação ao local. Leio assim, pois ele alista a palavra 'respeito' no mesmo contexto das outras palavras do desenho, que se referem à ação dos imigrantes bolivianos, em que ele e sua família estão incluídos, e não dos nacionais. Para ele, assim será incluído, aceito socialmente e alcançará seu objetivo bucólico mesmo em terras estrangeiras.

Abordarei agora a questão da reificação pela naturalização como modo de operacionalização de ideologia, conforme proposto por Thompson (1995).

\section{Excerto 16 - Reificação pela naturalização: Carolina 48}

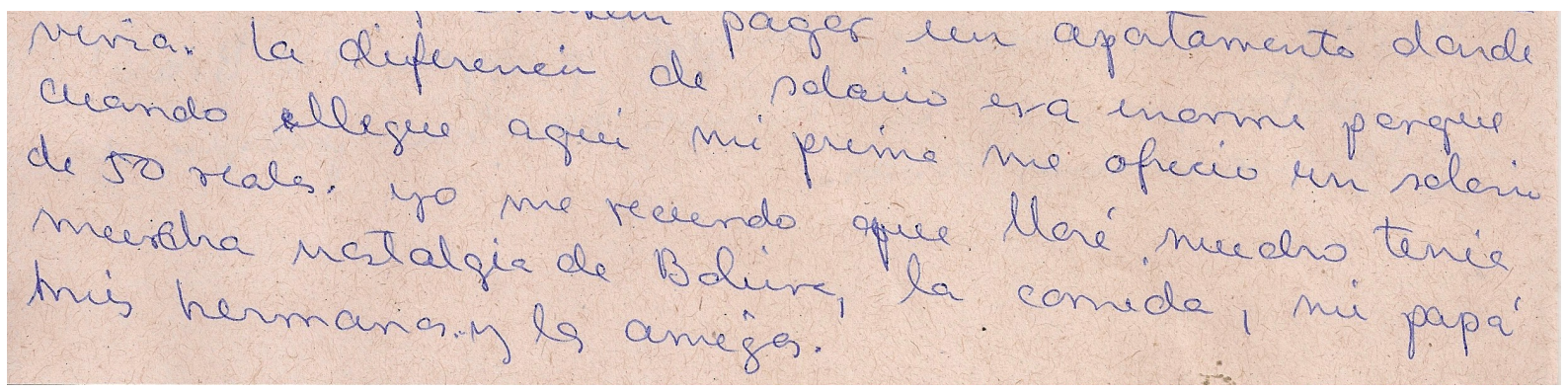

48 “A diferença salarial era enorme porque quando cheguei aqui, minha prima me ofereceu um salário de R\$ 50,00. Lembro-me que chorei muito e sentia uma saudade imensa da Bolívia, da comida, de meus pais, dos meus irmãos e dos meus amigos." 
Aqui, Carolina retoma a questão salarial, considerada em outro momento nestas análises, e como esta a afetou pessoalmente. Na ideologia como reificação, as relações de poder são estabelecidas pela retração ou eliminação da natureza sociohistórica das narrativas dos dominados. Esse processo ocorre pela naturalização quando os eventos são parte do tecido social, porém são considerados como acontecimentos naturais, inevitáveis e, por isso, devem ser aceitos. Para Carolina, não havia outra alternativa a não ser aceitar a questão salarial proposta pela familiar que a trouxe; ela deveria encarar a situação como natural, típica da realidade objetiva e, portanto, imutável para os imigrantes bolivianos, os estrangeiros.

É interessante notar que sua narrativa visual reflete exatamente esse momento de sua vida, acentuado pelo que ela assistiu no videoclipe sobre a Bolívia.

Figura 9 - Narrativa visual: Carolina

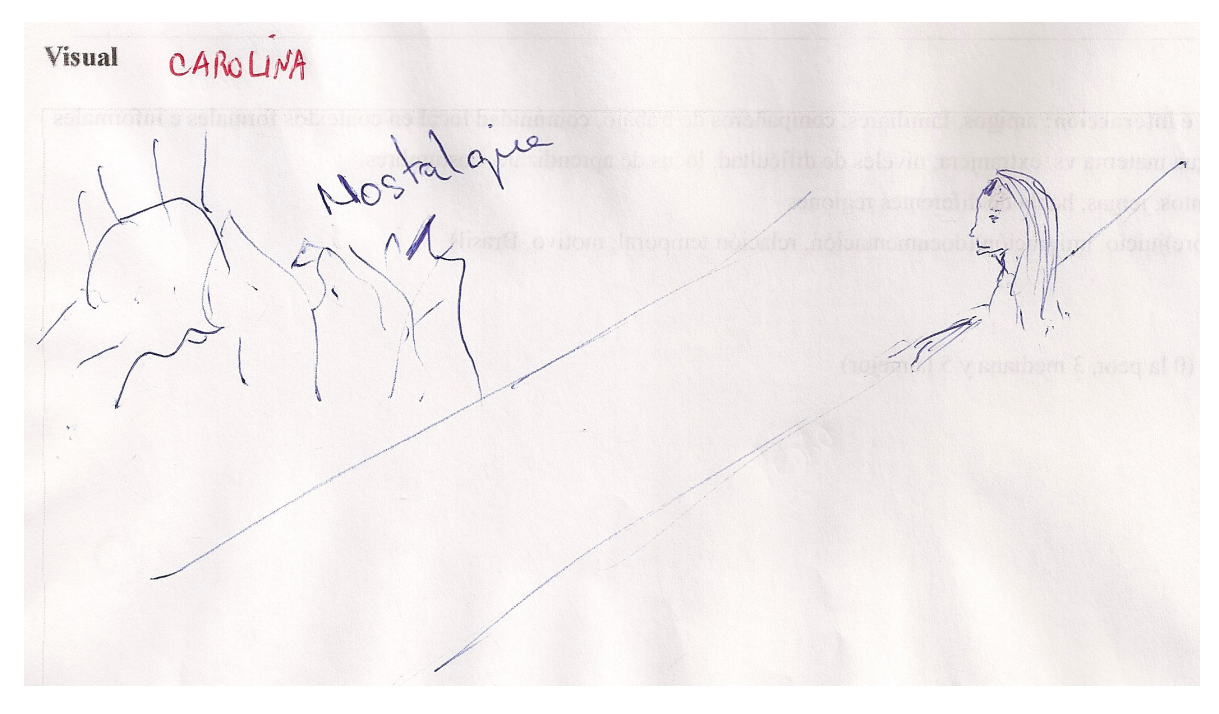

Na imagem, Carolina prefigura a si mesma como estando presa neste lado da fronteira Brasil-Bolívia e sem opções de retorno. O que lhe resta é apenas ser invadida por uma imensa saudade, um forte sentimento de nostalgia, do seu país e pelas paisagens que a cercavam antes de imigrar para o Brasil. Deste lado, no Brasil, não há nada que a vincule ao país - nem sequer as paisagens. Infelizmente, resta-lhe apenas internalizar a situação e encará-la como natural, imutável; reificá-la pela naturalização, como concebe Thompson (2002a). 
Esse sentimento de (in)visibilidade de Carolina, em relação ao Brasil, se relaciona com o que assevera Rancière (1996) ao comparar nossos tempos aos da Grécia antiga:

não há o que discutir com os plebeus [os imigrantes, acrescento eu] pela simples razão de que estes não falam. E não falam porque são serem sem nome, privados de logos, quer dizer de inscrição simbólica na pólis (...); [apenas] distribuem seus corpos na visibilidade e invisibilidade e põe em concordância os modos de ser, os modos de fazer e os modos do dizer que convém a cada um (RANCIÈRE, 1996, p. 37-40).

Como diz o autor, Carolina, em sua narrativa visual, "não fala, não tem nome (...) não tem inscrição simbólica" na sociedade; não está incluída, apenas "distribui seu corpo na [ora] visibilidade, [ora] invisibilidade”. Assim, na sociedade local, não são incluídos os (in)visíveis.

Por fim, quero apresentar ao leitor a narrativa visual de José e o comentário que ele fez para explicá-la e relacioná-la com o que assistiu do videoclipe.

\section{Excerto 17 - Reificação pela naturalização: José}

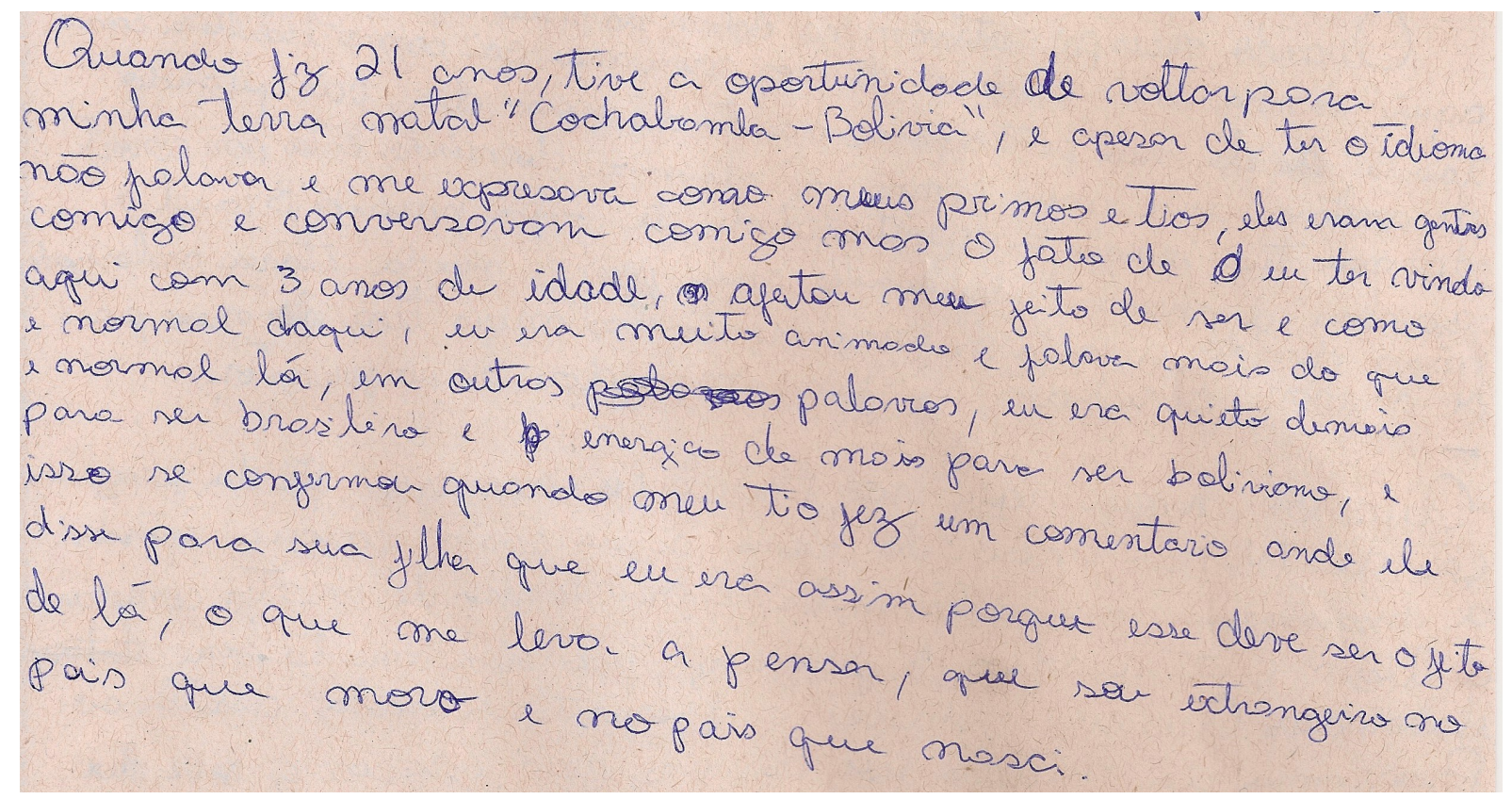

Ver o videoclipe despertou em José sentimentos bastante ambíguos, pois este o remeteu a um evento traumático em sua vida. Para ele, o ser boliviano já era um assunto resolvido, ou seja, ele entendia que jamais se sentiria excluído como boliviano em seu país e, portanto, nada na Bolívia teria a mais mínima relação com o que ele, e sua família, passaram 
no Brasil. Para ele, seu histórico e postura familiar, enquanto morador do Brasil, foi marcado por um apego incondicional às tradições e costumes de sua terra natal, a Bolívia.

Tamanha não foi sua decepção, ao perceber que o ser 'normal' no Brasil era diferente do ser 'normal' na Bolívia, o seu 'jeito de ser' boliviano havia sido afetado pelo do Brasil, sem que ele pudesse perceber. E, "apesar de ter o idioma, não falava e se expressava como seus tios e primos [bolivianos]". Para José, houve constrangimento e ele sentiu-se excluído em seu próprio país, pois seu tio, seu sangue, disse para sua prima que "ele [José] era assim porque [seu] jeito deve ser o jeito de lá [do Brasil]." Esse comentário o afeta a tal ponto de José concluir: "sou estrangeiro no país que moro e no país que nasci", ou seja, ele se sente duplamente excluído socialmente; sentimento de exclusão refletido em sua narrativa visual.

Figura 10 - Narrativa visual: José

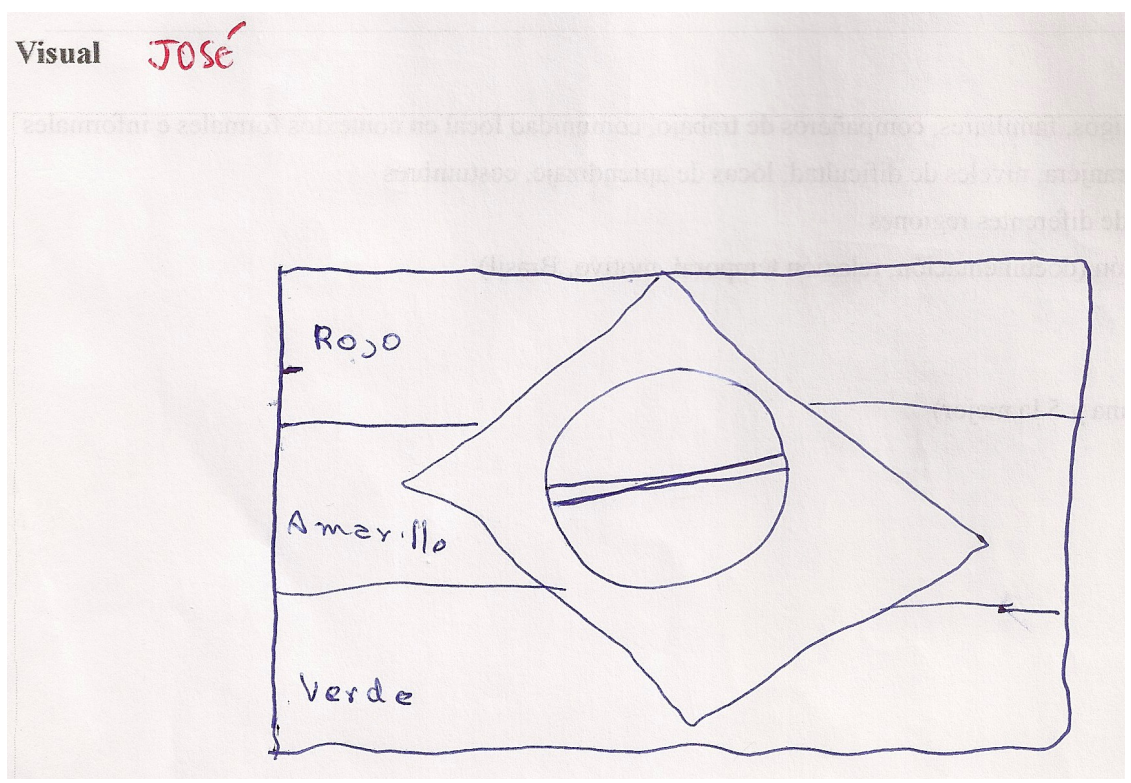

A narrativa de José, destaca o que Elias e Scotson (2000) apresentam em uma obra em que abordam a relação entre ser established e ser um outsider em um contexto social.

Essa relação revela as propriedades gerais de toda relação de poder. (...) se definem na relação que as nega e as constitui. Os indivíduos que fazem parte de ambas [que é curiosamente o caso de José] estão, ao mesmo tempo, separados e unidos por um laço tenso e desigual de interdependência. Superioridade social e moral, autoproteção e reconhecimento, pertencimento e exclusão são elementos dessa dimensão da vida social (ELIAS; SCOTSON, 2000, p. 8). 
Para José, seria bom se houvesse um país duplo, ou seja, se a Bolívia e o Brasil fossem apenas um, pois, assim, ele não seria estrangeiro em nenhum dos dois. Não seria nem um "established" nem um "outsider", "separado e unido por um laço tenso e desigual de interdependência”, como destacam os autores acima. José não se sentiria excluído em nenhum dos dois países e, portanto, não teria que conviver com esse sentimento ambíguo. Embora, a ideologia como reificação pela naturalização seja a sua realidade, para ele é difícil aceitar que as coisas devam ser encaradas como imutáveis e naturais; ser estrangeiro não é natural.

Na perspectiva da Análise de Discurso Crítica, entendo que ideologia se refere a um construto peculiarmente negativo e usado para a manutenção de poder hegemônico. Esse poder é propagado pela ideia de que representações particulares, ou coletivas, do mundo são únicas e legitimas (RAMALHO; RESENDE, 2011). Fairclough arremata dizendo que:

se alguém se torna consciente de que um determinado aspecto do senso comum sustenta desigualdades de poder em detrimento de si próprio, aquele aspecto deixa de ser senso comum e pode perder a potencialidade de sustentar desigualdades de poder, isto é, de funcionar ideologicamente (FAIRCLOUGH, 1989, p. 85).

Em outras palavras, se as ideologias são desveladas, trazidas à luz, os dominadores perdem sua capacidade de sustentá-las e, por conseguinte, de tirar proveito do ciclo de desigualdades e injustiças que se forma em torno delas. Daí, minha decisão de utilizar esse recorte do arcabouço teórico da Análise de Discurso Crítica para trazer à baila as ideologias submersas que sustentam ações de injustiças e desigualdades sociais envolvendo os imigrantes bolivianos, no bairro Bom Retiro, em São Paulo. Tais ações servem apenas para mantê-los apartados, excluídos da sociedade local e buscando sempre o "seu canto".

\subsection{A Teoria da Avaliatividade e o desvelar de identidades (des)construídas}

Numa música de 1967, chamada I am the Walrus, John Lennon destaca, em um dos versos, a relação cíclica de identificação social entre os diferentes indivíduos que fazem parte de uma sociedade. Para ele, no final das contas, todos serão parte de um mesmo todo ${ }^{49}$.

\footnotetext{
${ }^{49}[\ldots] \mathrm{I}$ am he as you are he as you are me; and we are all together $[\ldots]$
} 
Essa questão, ao meu ver, alinha-se muito bem com esta fase de minhas análises em que compartilharei, com o leitor amigo, algumas impressões obtidas dos participantes da pesquisa após assistirem a um videoclipe musical ${ }^{50}$, em que a cantora aborda a questão identitária do(s) imigrante(s). O foco central será uma análise de trechos específicos da letra da música, a partir de um subsistema da Teoria da Avaliatividade, que pertence ao quadro teórico mais amplo da Linguística Sistêmico-Funcional, que aborda a questão da identidade.

Em linhas gerais, a Linguística Sistêmico-Funcional (LSF) concebe a linguagem como sistema sociossemiótico composta de um conjunto de recursos semióticos construídos quer em contextos pessoais e com significados individuais, quer em processos sociais e em contextos com demandas específicas, numa relação societal dialético-dialógica (SÁ, 2014).

Dentro do espectro teórico da teoria em tela, organizada nas metafunções textual, ideacional e interpessoal, centrar-me-ei na última metafunção, a interpessoal. Nesta, a língua(gem) se movimenta, de forma dinâmica e fluida, na tessitura social dentro de um espectro conotativo e denotativo, centrado nas personagens, nas relações (a)simétricas e nas (inter)ações sociais em múltiplos contextos de situação e de cultura.

É dentro dos pressupostos da metafunção interpessoal que podemos abordar/analisar a questão da (des)construção identitária dos imigrantes bolivianos; e, ainda em tais pressupostos, se insere a Teoria da Avaliatividade, organizada em subsistemas e categorias.

Ao chamar a atenção para um dos problemas que podem advir da língua(gem) em uso na sociedade, nessa relação entre indivíduos e a coletividade, um dos mentores da LSF alerta:

(...) o aumento do lixo, a contaminação do ar e água, incluindo os processos mais letais da contaminação física parecem ser mais fáceis de tratar do que a contaminação do meio social causada pelos preconceitos e animosidade de raça, cultura e classe (HALLIDAY, 1982, p. 18).

Concordo com a declaração de Halliday, ainda que bastante impactantes, pois, assumo a dor dos imigrantes bolivianos em São Paulo vitimados pelo que se denuncia acima. Trato aqui não apenas da dor dos bolivianos, mas de todos os imigrantes que saem de sua terra natal, deixando atrás suas raízes familiares, sociais, culturais e históricas. Vão em busca de

50 Música: El emigrante, Normiqueen. Disponível: www.normiqueen.com/\#!videos/c9qb. Acessado em $29 / 12 / 2014$ 
um eldorado onde não haja injustiças sociais. Entretanto, acabam por serem obrigados a enfrentar outro(s) tipo(s) de injustiça(s): as ações xenofóbicas da terra acolhedora.

Passo agora a consideração do videoclipe musical mencionado. Incialmente apresentarei a letra da música, originalmente escrita em Espanhol, e uma tradução livre feita por mim mesmo. Em seguida, destacarei alguns trechos da música que usarei para demonstrar, a partir dos pressupostos teóricos eleitos para essa consideração, como a identidade do(s) imigrante(s) é afetada nesse processo de trânsito internacional. Fiz algumas inserções entre parêntesis, na tradução, para facilitar a compreensão das ideias originais.

Esta canção faz parte da discografia de Norma Delia Espinosa Zamora, Normiqueen, que nasceu em Bayamo, Cuba, em 4 de janeiro de 1987. Passou sua juventude na terra cálida de Santiago de Cuba e aos quinze anos de idade imigrou para a Finlândia, onde reside atualmente. Estudou Desenho e Comunicação Social, mas sua paixão sempre foi a música.

Quadro 8-Música: El emigrante

El emigrante $\quad$ O imigrante

\begin{tabular}{|c|c|}
\hline $\begin{array}{l}\text { Aha, es Normiqueen, Yalorde Records, y } \\
\text { produce el Xirujano }\end{array}$ & $\begin{array}{l}\text { Aha, aqui é Normiqueen, da Yalorde } \\
\text { Records e produzido por Xirujano }\end{array}$ \\
\hline Hay buenas máquinas & Produção de primeira \\
\hline Esto está dedicado a todos los emigrantes & Dedico esta a todos os imigrantes \\
\hline especialmente a mis hermanos cubanos & em especial aos meus irmãos cubanos \\
\hline Esto está difícil, hay que prosperar, avanzar & $\begin{array}{l}\text { Está difícil, (mas) é preciso prosperar e } \\
\text { progredir }\end{array}$ \\
\hline $\begin{array}{l}\text { La necesidad y el hambre, tus hijos no deben } \\
\text { experimentar }\end{array}$ & $\begin{array}{l}\text { A necessidade e a fome, teus filhos não } \\
\text { devem provar }\end{array}$ \\
\hline $\begin{array}{l}\text { La perseverancia por triunfar, salir adelante, } \\
\text { te convirtieron en emigrante }\end{array}$ & $\begin{array}{l}\text { A persistência para poder triunfar, ser bem- } \\
\text { sucedido, te transformaram em um imigrante }\end{array}$ \\
\hline $\begin{array}{l}\text { Tomar esa decisión tan triste, dejar la tierra } \\
\text { dónde naciste, creciste, viviste }\end{array}$ & $\begin{array}{l}\text { Tomar essa decisão tão triste, deixar a terra } \\
\text { onde você nasceu, cresceu e viveu }\end{array}$ \\
\hline Dejar todo atrás, a lo que estás acostumbrado & $\begin{array}{l}\text { Deixar para trás tudo (a que) está } \\
\text { acostumado }\end{array}$ \\
\hline Y tratar de resolver tu vida en otro lado & E tentar melhorar sua vida em outro lugar \\
\hline $\begin{array}{l}\text { Y llega el choque de cultura que sí la gente } \\
\text { fula }\end{array}$ & E aí vem o choque de cultura que te irrita \\
\hline
\end{tabular}


Que es el frío, que's la nieve, enfín, la temperatura

(La) distancia que nos separa de nuestra gente querida

Amigos, primos, hermanos, toda nuestra familia
O frio, a neve, enfim, a temperatura

(A) distância que nos separa de nossa gente querida

Amigos, primos, irmãos, toda nossa família

Aprender un nuevo idioma, volver a empezar Aprender uma nova língua, começar do zero de zero

¿Y cómo hago ahora, pa' conseguir dinero? E como faço para ganhar dinheiro?

Tu única esperanza es algún dia regresar a

Sua única esperança é voltar algum dia para esa tierra que tanto amas y tanto has de extrañar

¿Y qué serás, que no extrañas de tu país?

E do quê, no seu país, você não sente falta?

La gente pobre pasa hambre, sí, pero feliz

Os pobres passam fome, (mas) são felizes

Aquí, tengo de todo, cubro mis necesidades

Aqui tenho tudo (que preciso) para minhas necessidades

Pero no tengo el beso de "buenas noches" de mi abuela, ¿verdad?

Mas, não tenho o beijo de "boa noite" da minha avó, não é?

Como dice ese refrán: que Dios le dio barba a quien no tiene quijada

Como diz um dito popular: Deus não dá asa a cobra

¿Y que será? Que yo le extrañe de mi isla

E do quê não sinto falta de minha ilha?

Que tan solo recordarla me saca una sonriza Que só em lembrá-la me faz rir

La playa, carnaval, es matar el tiempo con la amistades, la cerveza, el ron, formar un buen rumbón, jugar cartas en el parque, trancar el dominó y ese cerdito asado cuando el viejo año dice adiós.

Yo nací en una isla que se llama Cuba A praia, o carnaval, passar tempo com os amigos, a cerveja, o rum, os grupos de dança, os jogos de baralho no parque, as partidas de dominó, o leitão assado nas festas de ano novo

Eu nasci em uma ilha que se chama Cuba

Dónde pa' emigrar casi siempre hay que Onde quase sempre é necessário fugir se buscar su lluva/yuva quiser imigrar

Y no se puede criticar, ¿qué vamos a hacer? E não se pode criticar nem fazer nada

Si ahí hasta por pensar te pueden desaparecer (Pois), até por pensar dão um sumiço em você

Muchos se prostituyen, roban para comer Muitos se prostituem (e) roubam para comer 
Pues los mandados en la libreta no alcanzan para el més

¿Y qué cosa es la libreta? Ven que te lo hago saber

Es un papel que dice cuanto el cubano debe comer al més

Sí, así es la vida

Del emigrante

Que dejó todo atrás

Pa'seguir adelante

Dios mediante la cosa algún dia cambie

Y regrese a sua tierra de dónde nunca debió marcharse

Sí, así es la vida

D’estas personas

Que cuentan años, meses, días, inclusive horas

Para unirse con su gente, que tanto añora

Pues eso es lo que su corazón ahorita s' implora

Ahora estás del lado (d')acá

Y con una mejor vida, mas a la hora de comer

Piensas qué come tu família

Una mini llamada te llena por un momento
(Visto que) o salário no seu holerite não dá para nada

O que é holerite? (Venha que) te explico

É um papel que diz quanto o cubano pode comer por mês

Sim, assim é a vida

Do imigrante

Que deixou tudo para trás

Para ser bem-sucedido

(E que espera) em Deus que as coisas mudem algum dia

E ele possa voltar a terra de onde nunca deveria ter saído

Sim, assim é a vida

Dessas pessoas

Que contam os anos, meses, dias e inclusive horas

Para se juntar com seu povo (de quem) sente tanta saudade

(Visto que) isso é o que seu coração sempre implora

Agora (que) está desse lado

E com uma vida melhor, mas (que) na hora de comer

Pensa no que está comendo sua família

Uma breve ligação telefônica até satisfaz por uns instantes

Mas la nostalgia te invade a medida que pasa el tiempo

Mas a saudade volta a invadir a medida que o tempo passa

Daqui (é que) podemos ver (e) dar valor

A tudo (que) tínhamos, e não nos dávamos conta 


\begin{tabular}{|c|c|}
\hline $\begin{array}{l}\text { Estamos a veces tan ocupados que olvidamos } \\
\text { darle amor a toda la gente que en realidad } \\
\text { amamos }\end{array}$ & $\begin{array}{l}\text { Estamos tão ocupados às vezes que } \\
\text { esquecemos de demonstrar amor a } \\
\text { todos (aqueles) que amamos de verdade }\end{array}$ \\
\hline $\begin{array}{l}\text { Nos consuela el dinerito que mandamos } \\
\text { mensualmente, incuerentes }\end{array}$ & $\begin{array}{l}\text { O dinheirinho que mandamos mensalmente } \\
\text { nos consola, mas isto é incoerente! }\end{array}$ \\
\hline $\begin{array}{l}\text { Esos sentimentos encontrados es saber que } \\
\text { desde aquí y sin tanto que decir ayudas más } \\
\text { que estando allá obstinado, pero a su lado. }\end{array}$ & $\begin{array}{l}\text { Esses sentimentos confusos (ao saber que) } \\
\text { mesmo de longe e sem poder falar muito } \\
\text { você ajuda (mais do que estando ao lado } \\
\text { deles, mas sem trabalho) }\end{array}$ \\
\hline $\begin{array}{l}\text { La soledad nos invade, la tristeza nos dá la } \\
\text { mano }\end{array}$ & $\begin{array}{l}\text { A solidão nos invade (e) a tristeza anda de } \\
\text { mãos dadas (conosco) }\end{array}$ \\
\hline $\begin{array}{l}\text { Todo eso que tienes ya no te importas ni un } \\
\text { carajo }\end{array}$ & $\begin{array}{l}\text { Tudo o que você tem agora não te serve para } \\
\text { nada }\end{array}$ \\
\hline ¿Qué hago? & Que fazer? \\
\hline Con casa, comida y carro & (Se) tenho casa, comida e carro \\
\hline $\begin{array}{l}\text { Si a mi familia un ciclón el techo se lo trajo } \\
\text { abajo }\end{array}$ & $\begin{array}{l}\text { (Mas), um ciclone derrubou a casa da minha } \\
\text { família }\end{array}$ \\
\hline Esa preocupación, palpitó del corazón & Essa preocupação bate forte no coração \\
\hline $\begin{array}{l}\text { Cuando a medianoche de momento tu móvil } \\
\text { sonó }\end{array}$ & Quando à meia-noite seu celular toca \\
\hline La razón de esa llamada tan doliente & (E) a razão dessa chamada tão doída \\
\hline $\begin{array}{l}\text { Para te dar notícia de que se te murió un } \\
\text { pariente }\end{array}$ & É para te avisar de que um parente morreu \\
\hline La vida no es siempre hermosa & $\begin{array}{l}\text { A vida não é sempre tão bonita (quanto } \\
\text { parece) }\end{array}$ \\
\hline No todo es color de rosa & Nem tudo é um mar de rosas \\
\hline Recuerda que de una oruga, salió la mariposa & $\begin{array}{l}\text { Lembre-se que (a) borboleta nasce de uma } \\
\text { lagarta }\end{array}$ \\
\hline ¡Ahora, goza! & Aproveite (a vida) agora! \\
\hline De lo poco que tienes & (Aproveite) o pouco que tens \\
\hline $\begin{array}{l}\text { Que algún día estarás con la gente que tú } \\
\text { quieres }\end{array}$ & Pois algum dia você estará com quem te ama \\
\hline ¡Sacrifícios! & Sacrifícios! \\
\hline De esto está llena la vida & A vida está cheia deles \\
\hline
\end{tabular}




\begin{tabular}{|c|c|}
\hline ¡Sufrimientos! & Sofrimentos! \\
\hline Pues las cosas tristes no se olvidan & $\begin{array}{l}\text { (Visto que) não dá para esquecer as coisas } \\
\text { tristes }\end{array}$ \\
\hline Ahora caminas & Agora (você) anda \\
\hline Tu, siempre (apuesto) y elegante & Sempre bem arrumado e elegante \\
\hline $\begin{array}{l}\text { Que' stá la vida que nos tocó a los } \\
\text { emigrantes }\end{array}$ & (Pois), esta é a vida dos imigrantes \\
\hline Estribillo & Refrão \\
\hline Sí, así es la vida & Sim, assim é a vida \\
\hline Del emigrante & Do imigrante \\
\hline Es triste caballero & É triste, meu senhor \\
\hline Pero, ¡hay que seguir parante! & Mas, não dá para desistir! \\
\hline (EI emigrante, Joselito) & (O imigrante, Joselito) \\
\hline Cuando salí de mi tierra & (Quando) saí da minha terra \\
\hline Volví la cara llorando & Saí com lágrimas nos olhos \\
\hline Porque lo que más queria & Porque os a quem eu mais amava \\
\hline Atrás me lo iba dejando & Estava deixando atrás \\
\hline
\end{tabular}

Fonte: Quadro elaborado pelo autor (2015)

$\mathrm{Na}$ metafunção interpessoal, o papel discursivo do interlocutor é centrado no ato de dar/trocar informações e, o faz, através do uso excessivo de declarações e interrogações cujo objetivo semântico é propor uma reflexão ao ouvinte/leitor sobre alguma temática de ordem social que o preocupa/aflige. Ao ler a letra da música notamos que a cantora tem essa preocupação em cada um dos versos e na maneira como os estruturou.

Exemplifico o acima, nos versos: "[...] A persistência para poder triunfar, ser bemsucedido, te transformaram em um imigrante"; “[...] Tomar essa decisão tão triste, deixar a terra onde você nasceu, cresceu e viveu”; “[...] E como faço para ganhar dinheiro?”; “[...] Muitos se prostituem (e) roubam para comer"; “[...] Que fazer?”; etc. Com esses poucos versos que uso para exemplificar as asserções do parágrafo anterior, ilustro como a cantora quer que reflitamos sobre a situação do imigrante, seus conflitos e seus dissabores. 
Por um viés bastante inesperado por mim, e diferente dos outros participantes, veja no excerto abaixo como um dos participantes, Pedro, extraiu do videoclipe musical, sentimentos positivos acerca de sua relação como imigrante no Brasil.

Excerto 18 - Comentário sobre o videoclipe: Pedro ${ }^{51}$

Videoclipe: El emigrante (Normiqueen)

Escritura

Me siento como un viryoro bién atendido. Estando en mí pais ture aprecio por ella; por su rica diversidad de climas,

tipos de regetación, gento, música, tipos de comida. cuando legué a Brariel senti el mismo respeto y oprecio, esa es la actitod que me mantuvo estor 20 años aqué if prenso que montendió todaría.

Aqui, Pedro envolvido em um processo de dupla identificação, enxerga no vídeo que há algo de bom e positivo ao imigrar. Quer que saibamos que esse processo envolve escolhas e que, em seu caso particular, ter vindo para o Brasil foi uma experiência que valeu à pena.

Outro conceito interessante que encontramos na obra de Halliday e que vale ressaltar na canção se relaciona com conceito de antilinguagem. Este implica a investigação da reconstrução da vida na/pela língua(gem) realizada em condições de tensão social e na (re)construção de significados em contextos de conflito social o que, pressupõe, a existência de uma anti-sociedade (SÁ, 2014). Halliday (1982), diz que "uma anti-sociedade é uma sociedade que se estabelece dentro de outra como alternativa consciente a esta, um modo de resistência, que pode adotar a forma de simbiose passiva ou hostilidade ativa" (p. 213). Veja na imagem abaixo um exemplo de anti-sociedade dentro do conceito de antilinguagem:

\footnotetext{
51 "sinto-me como um viajante bem assessorado. Estando no meus país, senti apreço por ele; pela rica diversidade de climas, tipos de vegetação, gente, música, tipos de comida. Quando cheguei ao Brasil senti o mesmo respeito e apreço; essa é a atitude que me manteve aqui por estes 20 anos e imagino ainda que me manterá."
} 
Figura 11 - Anti-sociedade

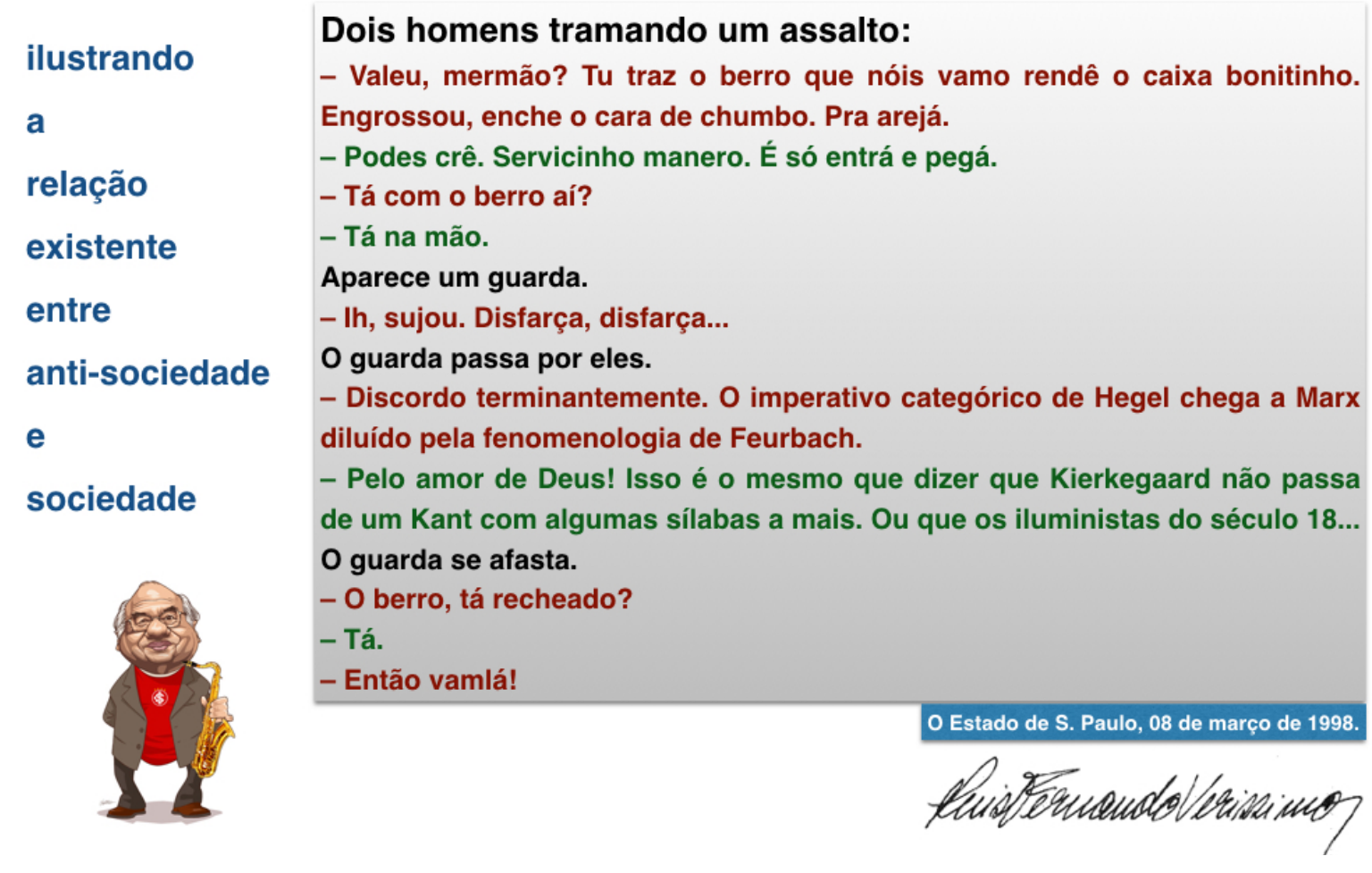

Fonte: Imagem elaborada pelo autor (2015)

A figura acima ilustra o conceito de antilinguagem, nos termos propostos por Halliday (op.cit.). Esse conceito se relaciona com a situação dos imigrantes (bolivianos), conforme ilustra a letra da música em análise. Esta, apresenta em vários momentos a existência dessa (anti)sociedade de resistência, simbiótica e, às vezes, hostil. Exemplos são vistos nos versos: “[...] Aprender uma nova língua, começar do zero”; “[...] Daqui (é que) podemos ver (e) dar valor"; "[...] Tudo o que você tem agora não te serve para nada”; etc.

No excerto de Mariana, vi um processo interessante nesse movimento de anti-sociedade/antilinguagem, parte desse processo de (des)construção identitária.

Excerto 19 - Comentário sobre o videoclipe: Mariana

\section{Videoclipe: El emigrante (Normiqueen)}

\section{Escritura}

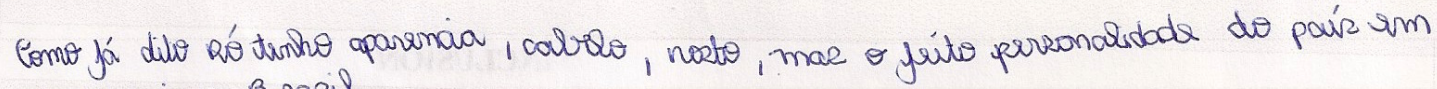
que narci o Burail 
Durante todas as atividades no grupo focal, Mariana vive um movimento duplo de identificação com a cultura boliviana, dos pais e da irmã, fortemente arraigadas no seio familiar, comunitário e religioso em que transita. Ora Mariana identifica-se como sendo boliviana ora nega sê-lo e arroga para si a nacionalidade brasileira.

Após assistir o videoclipe, notei que Mariana passou por um momento de silêncio e, ao ser convidada a escrever suas impressões sobre o que viu, ela opta por reforçar que ela é brasileira; quer reforçar sua identidade como sendo brasileira e que a única coisa que guarda relação com a Bolívia é sua aparência, cabelo, rosto. Reforça que seu jeito, personalidade é do país em que nasc(eu), o Brasil. Vejo aqui um movimento inverso no conceito de antisociedade/antilinguagem conforme proposto neste texto. $\mathrm{O}$ videoclipe fez com que Mariana adotasse uma atitude hostil e de resistência ao sofrimento dos imigrantes retratado no videoclipe e narrado na letra da música.

Reforço, que todo o acima abordado, está relacionado com a questão da (des)construção identitária dos imigrantes. Entro neste esteio a partir dos pressupostos da Teoria da Avaliatividade. Introduzo o tema com a citação:

Halliday (1994) discute que qualquer análise de discurso é sempre feita em dois níveis: o primeiro é a compreensão do texto: a análise linguística que permite que se mostre como e por que o texto significa o que significa; o outro nível é uma contribuição à avaliação do texto: a análise permite que se diga o motivo pelo qual o texto é ou não eficaz para os seus propósitos, e requer não somente uma compreensão do texto, mas também de seu[s] contexto[s] e do relacionamento sistemático entre o contexto e o texto (MORAIS, 2012, p. 72).

No nível de avaliação textual, objetivo verificar a atitute e os objetivos da cantora em relação à identidade do imigrante que é (des)construída no processo de imigração. No subsistema de atitude da Teoria da Avaliatividade, o participante expressa seus sentimentos num tom discursivo específico, um tom que se relaciona com seu papel discursivo e as relações que estão envolvidas nesse processo.

Lemos, numa tradução livre feita por mim: 
O tom [discursivo] se relaciona com a natureza, os papéis e o status dos participantes: o tipo de relações advindas, inclusive as de natureza prementes e temporárias, de um ou outro modo; [envolve] tanto os tipos de papéis discursivos em que estão engajados e todo o cenário social em que estão envolvidos (HALLIDAY, 1985b, p. 12) ${ }^{52}$.

Outro pesquisador do subsistema de atitude, na Teoria da Avaliatividade, acrescenta ${ }^{53}$ : "[Se refere a] como os interlocutores se sentem, os julgamentos que fazem, e o valor que atribuem aos vários fenômenos de sua experiência" (MARTIN, 2000, p. 144).

Veja no excerto abaixo, de outro participante, José, confirma-se a citação acima.

Excerto 20 - Comentário sobre o videoclipe: José

\section{Videoclipe: El emigrante (Normiqueen)}

Escritur:

Sair do pais no qual naxi, muito pequeno e crescer em outro com lingua e cultura diferente on foz senter que noo tentwo uma noscionolidocle, apesor de ter sido muito bena recebida, aindo assim un nöo me sinto parte de un paś, porem como orexi aqui posso dizer que me sonto mois confortoril aqui.

Ao tratar da experiência de sair da terra natal, vivida na infância, José mostra no excerto acima como se sente: me faz sentir que não tenho nacionalidade e não me sinto parte de um país. Ou seja, para José, sua identidade foi (des)construída a tal ponto de ele achar que não pertence a nenhum país, não ter nacionalidade. Por outro lado, chama minha atenção como ele julga o fenômeno da mudança a partir de sua experiência pessoal: ter sido muito bem recebido e me sinto mais confortável aqui. Vejo essa ambiguidade de declarações como marcas, cicatrizes dessa (des)construção de sua identidade como boliviano.

\footnotetext{
52 Tenor refers to who is taking part, to the nature of the participants, their statuses and roles: what kinds of role relationship obtain, including permanent and temporary relationships of one kind or another, both the types of speech roles they are taking on in the dialogue and the whole cluster of socially significant relationships in which they are involved.

53 How the interlocutors are feeling, the judgements they make, and the value they place in the various phenomena of their experience
} 
Nesta perspectiva, os falantes exprimem sua(s) postura(s), suas atitudes mentais e seus valores, conforme graficamente ilustrado pelos excertos de Pedro, Mariana e José. Na letra da música em análise, a cantora expressa o acima e marca sua identidade como imigrante, também ora positiva ora negativamente. Veja isso nos versos: “[...] E aí vem o choque de cultura que te irrita; "[...] O que é holerite? (Venha que) te explico"; “[...] Essa preocupação bate forte no coração"; etc. Amplio esse entendimento com a citação 54 :

Avaliatividade é um dos três recursos semântico-discursivos principais que constituem os significados interpessoal (junto com o engajamento e a negociação). [O Sistema] da Avaliatividade é organizado em três domínios de interação — atitude, gradação, e comprometimento (MARTIN \& WHITE, 2005, p. 34-35).

Veja a figura 12, abaixo, que esquematiza o Sistema da Avaliatividade:

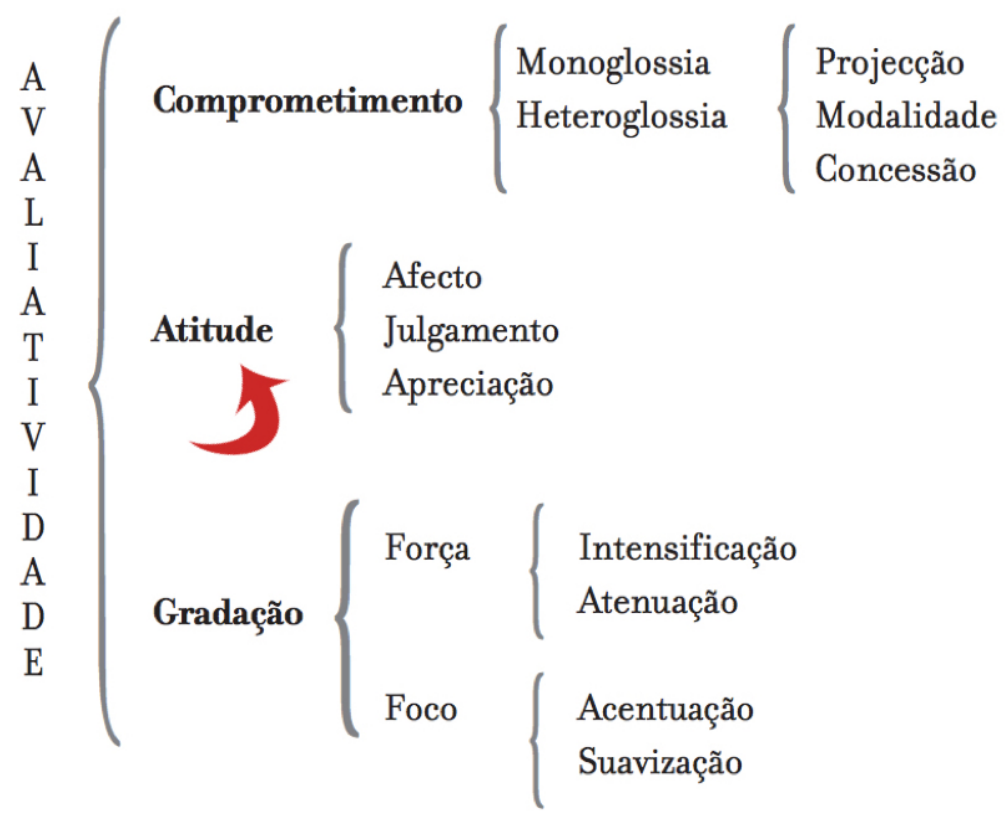

Fonte: AZUAGA; AVELAR, 2003, p. 29

Dentro do subsistema de atitude, o interlocutor se posiciona a partir de diferentes prismas, a saber, em relação à sua própria atitude, a do outro e em relação ao (inter)texto. Veja alguns exemplos extraídos da letra da música em tela: a) relativo à (própria) atitude: “[...] como faço para ganhar dinheiro?”; “[...] aqui tenho tudo para minhas necessidades”;

\footnotetext{
${ }^{54}$ Appraisal is one of three major discourse semantic resources construing interpersonal meaning (alongside involvement and negotiation). Appraisal itself is regionalised as three interacting domains - 'attitude', 'engagement', and 'graduation'.
} 
b) relativo ao outro: "[...] os pobres passam fome em Cuba"; "[...] muitos se prostituem"; e,

c) relativo ao (inter) texto: “[...] diz um dito popular: Deus não dá asa a cobra”; “[...] a borboleta nasce de uma lagarta". Vemos, nos exemplos citados, que a cantora se posiciona e mostra sua atitude em relação ao que significa ser imigrante e estar longe de sua terra natal. Evoca memórias, sentimentos múltiplos e conflituosos causados pela situação em outro país. $\mathrm{O}$ excerto a seguir retrata muito bem o que assevero, neste sentido.

Excerto 21 - Comentário sobre o videoclipe: Carolina 55

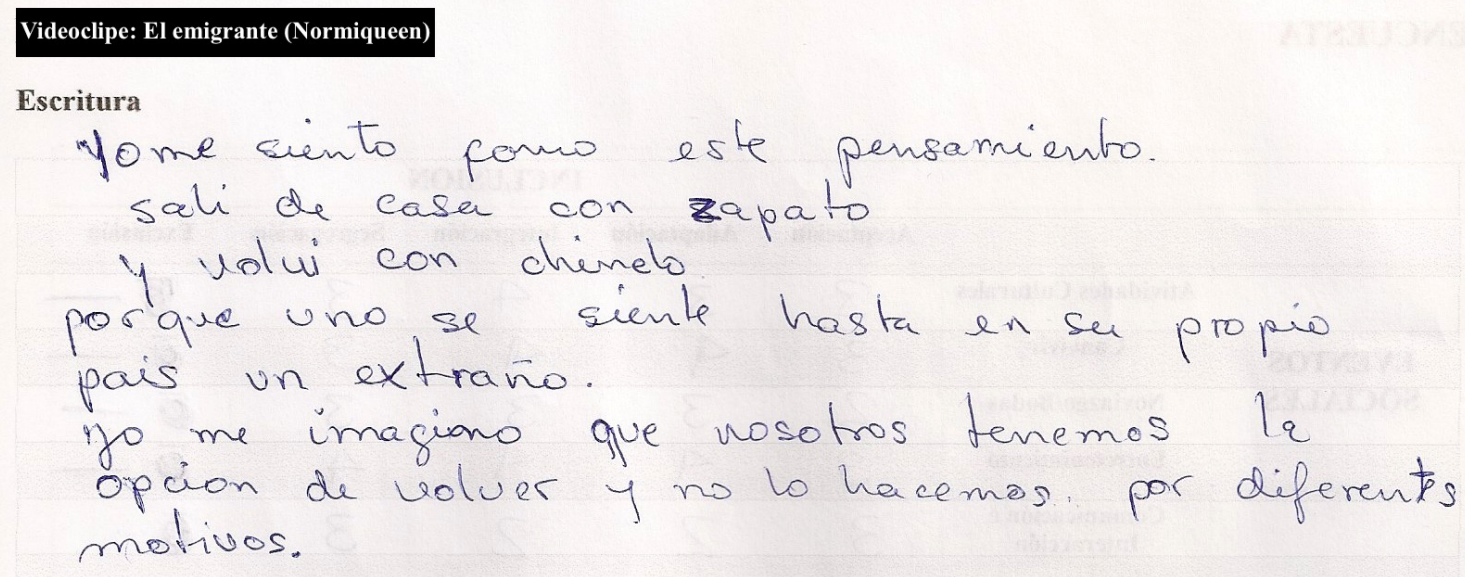

É forte a atitude e os sentimentos de Carolina em relação à imigração: sinto [que] saí de casa com sapatos e voltei de chinelos; ou seja, para ela, há sentimento de arrependimento, de perda e de frustração. Como se se sentisse culpada em seu pensamento de ter tomado a decisão errada ao deixar para trás o que tinha em seu país. Tal sentimento múltiplo e conflituoso é reforçado quando diz que [se] sente uma forasteira até mesmo em meu próprio país. Para Carolina, assim como na música, há o desejo constante e ardente de querer voltar às suas origens: penso que temos a opção de voltar. Entretanto, como sua identidade como boliviana está (des)construída, não [voltamos] por diferentes razões. Tudo isso se relaciona com a atitude em relação si mesma e ao outro, conforme preconiza a Avaliatividade.

55 "sinto-me com este pensamento: saí de casa com sapatos e voltei de chinelos. Porque me sinto uma forasteira até mesmo em meu próprio país. Penso que temos a opção de voltar, mas não o fazemos por diferentes razões." 
Seguindo com a consideração sobre o subsistema de atitude na Teoria da Avaliatividade, veja a figura abaixo que é um recorte da anterior.

Figura 13 - Categoria do Subsistema de Atitude

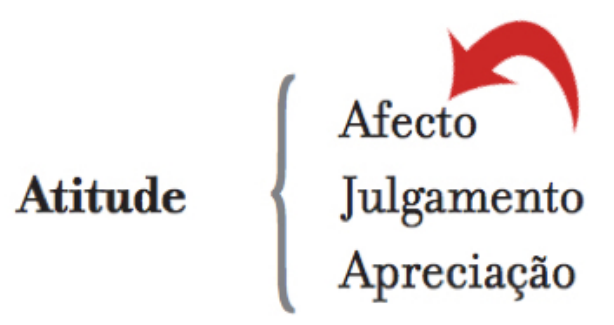

Fonte: adaptado pelo autor (2015)

(AZUAGA; AVELAR, 2003, p. 29)

$\mathrm{Na}$ figura acima vemos que o subsistema atitude é organizado em três categorias diferentes: afeto, julgamento e apreciação. Vou centrar-me na categoria afeto, que se significa:

O Afecto tem a ver com a manifestação das emoções, a reacção a um comportamento, a um fenómeno natural, a um estado-de-coisas, ou a um texto/processo. A manifestação das emoções reside na subjectividade individual do falante/escrevente que, por decisão ou necessidade própria, inscreve a sua presença no processo comunicativo (AZUAGA; AVELAR, 2003, p. 33).

Conforme demonstram os autores acima, essa categoria está intimamente relacionada com as atitudes associadas às emoções, às reações e ligadas às subjetividades ou, nos termos dessa análise, às identidades dos imigrantes. Vale ressaltar que essa categoria é realizado por meio de recursos gramaticais diversos. Veja, com grifos acrescentados, exemplos que encontramos na letra da música: a) circunstância: "Agora você anda sempre bem arrumado e elegante"; b) adjetivo: "Em Cuba os pobres são felizes"; c) processo: "[...] te transformaram em um imigrante"; d) comportamento: "E como faço para ganhar dinheiro?”; e) adjunto: “a razão dessa chamada tão doída”; f) polaridade: “Tudo o que você tem agora não te serve para nada"; g) gradação: "Nós mandamos o dinheirinho mensalmente"; e, h) estado emocional: "a solidão nos invade".

Apresento no excerto do último participante, Juan, como o afeto é demonstrado através de diferentes recursos gramaticais e como estes se relacionam com a questão de sua identidade, suas reações e emoções como imigrante boliviano residente em São Paulo. 
Excerto 22 - Comentário sobre o videoclipe: Juan ${ }^{56}$

\section{Videoclipe: El emigrante (Normiqueen)}

Escritura

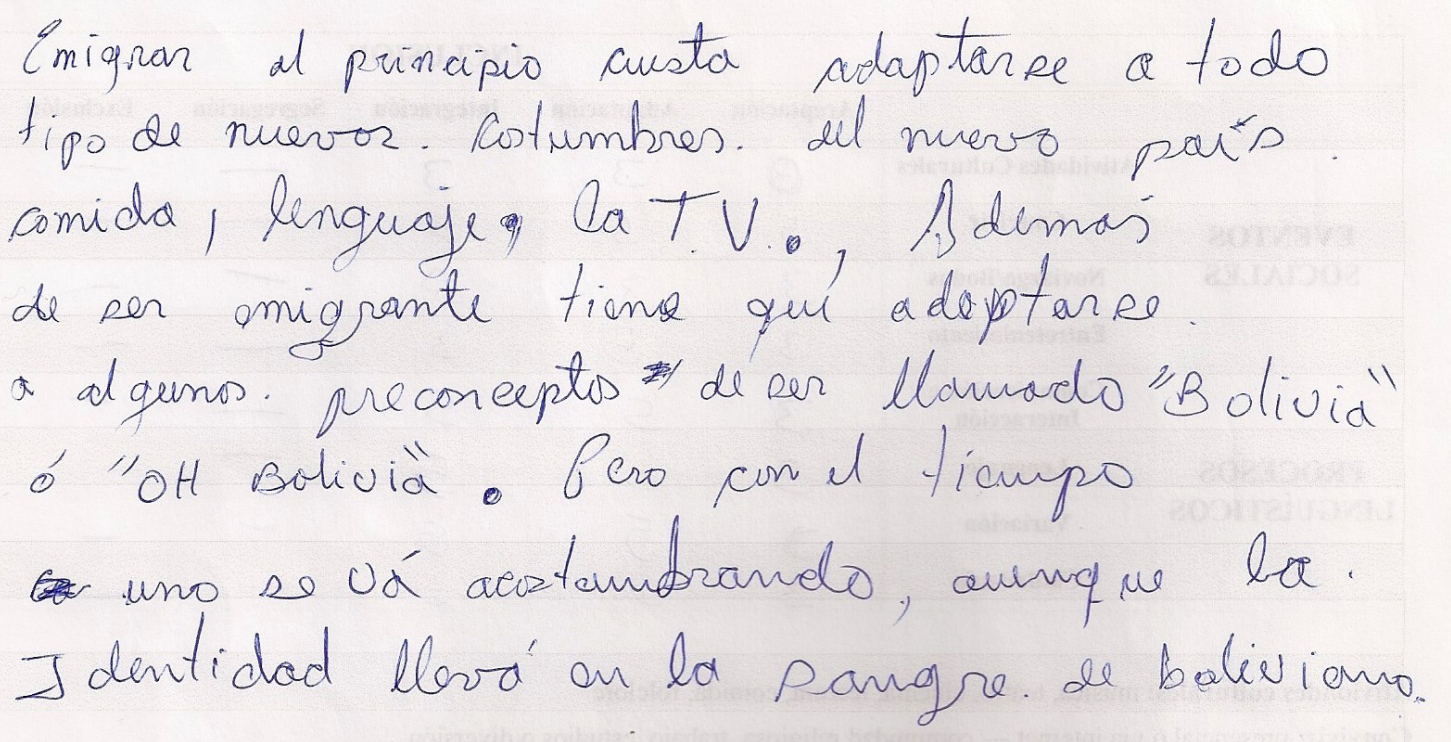

Assim, como demonstrei na letra da música, Juan usa em seu excerto vários recursos gramaticais para chamar a atenção para suas emoções e sua identidade como boliviano. Por exemplo, ele diz: a) processo: "custa adaptar-se"; b) modalidade: "tantas coisas novas"; c) nominalização: "adaptar-se a preconceitos"; d) polaridade negativa: "ser chamado de 'bolívia' ou 'ô bolívia"”; e) estado emocional de resistência: "sua identidade você leva no sangue de boliviano".

É interessante que Juan sugere as dificuldades enfrentadas como imigrante boliviano no Brasil, mas faz questão de reforçar sua identidade boliviana que leva no sangue. E, de fato, como já o descrevi, em outro momento neste texto, Juan é o participante que faz mais questão de preservar seus traços identitários bolivianos bem marcados em sua postura, fala, etc. Diferente de outros participantes nessa atividade do grupo focal, Juan usa o material do vídeo para destacar que ele é boliviano, no sangue e isso é algo não mudará.

À guisa de conclusão dessa última parte das análises, entendo que, no caso dos imigrantes, ocorra fragmentação e instabilidade identitária, às vezes contraditórias, pois eles, ao imigrarem, apenas anseiam a aceitação da comunidade local como são. No entanto, são

56 "No início, imigrar é difícil para adaptar-se a tantas coisas novas no novo país: costumes, comida, idioma, televisão. Além disso, você precisa adaptar-se a preconceitos, como ser chamado de 'bolívia' ou 'ô bolívia'. Mas, com o tempo, você vai se acostumando, embora sua identidade você leva no sangue de boliviano.” 
forçados, não num processo natural, como leio em Hall, Foucault, Bauman e outros, a abrir mão de sua cultura, tradição, língua e, consequentemente, identidade para receberem acesso a (esse) espaço social simbólico. Nesse processo, a letra da música eleita, para demonstrá-lo, indica que o imigrante passa por momentos de sentimentos bastante conflituosos. Embora reconheça os benefícios de tal mudança, sobretudo as de caráter financeiro, mas passa por um processo constante de avaliação para verificar se realmente vale à pena a troca que ele faz, a saber, o desenraizar-se por melhores condições de vida.

O que quero dizer com esse processo natural, em outras palavras, é que aos imigrantes não lhes é dada a oportunidade de participar do jogo de identidades, líquido, movediço e imprevisível, em que eles mesmos possam atuar como agentes dessa inevitável (des)construção. Concluo, então, com as sábias palavras de um respeitado sociólogo Francês, quando ele diz que "talvez não exista pior privação, pior carência, que a dos perdedores na luta simbólica por reconhecimento, por acesso a uma existência socialmente reconhecida, em suma, por humanidade" (BOURDIEU, 2000, p. 242).

Arrematando meu capítulo de análises, gostaria de salientar que as histórias de vida os imigrantes bolivianos, que participaram nessa pesquisa, são, o que posso chamar de 'imagens em movimento'. Sendo tais, nunca haverá uma análise, feita por mim ou outrem, que capte uma verdade única do texto que tais histórias produzem. O que tentei arduamente fazer foi ser o mais explícito e objetivo possível a despeito dos recursos que utilizei na coleta dos dados. Como linguista, estudioso do discurso, busquei, nas entrelinhas, das falas dos bolivianos entender como ocorre o processo de invisibilidade, de exclusão e de (des)construção identitária dos imigrantes no contexto social em que estão inseridos.

Reconheço, entretanto, como pesquisador que "as inconsistências e contradições são parte do processo contínuo do projeto de pesquisa"; não obstante, procurei garantir a excelência desse trabalho através da "boa documentação, da transparência e da clareza nos procedimentos na busca e na análise dos dados” (BAUER; GASKELL, 2013, p. 483).

Meu desejo sincero é que, o leitor amigo, tenha aumentado sua compreensão dos processos de (in)visibilidade, exclusão e (des)construção identitária envolvendo os imigrantes bolivianos. Como cientistas sociais e pesquisadores de vidas e dores alheias, espero ter contribuído para sua satisfação e sede de conhecimento e entendimento dos objetos de pesquisa que propus no início dessa jornada científico-acadêmica e, sobretudo, social. 


\section{CAPÍTULO 5}

\section{Constatações: "Terra à vista!"}

Foto 6 - Dista no horizonte!

"Vejo os navios (eles durarão alguns anos), As grandes fábricas, seus capatazes e empregados, E ouço a aprovação a tudo isso, e a isso não me oponho." - Walt Whitman

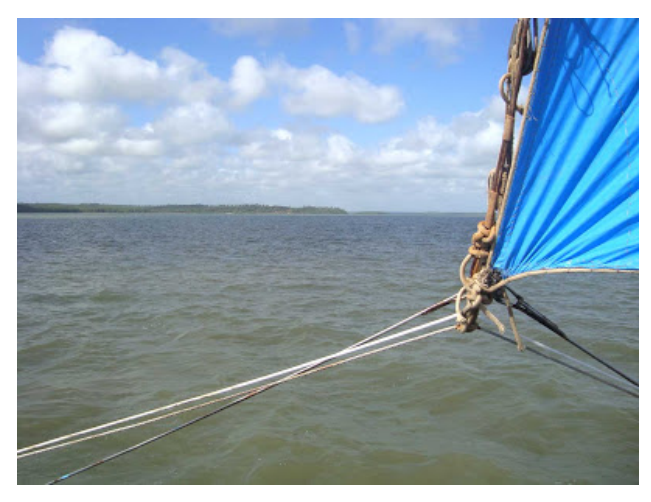

Fonte: Google 57

5.1. À guisa de (in)conclusões

"Enquanto isso, navegando vou sem paz. Sem ter um porto, quase morto, sem um cais".

— Los Hermanos

\section{Pedro:}

"preferimos ficar no nosso canto, pois estamos conscientes que somos estrangeiros"

\section{Carolina:}

“chorei muito e sentia muita saudade da Bolívia; não deixamos de ser estrangeiros”

José:

"sou estrangeiro no país que moro e no país onde nasci"

\section{Mariana:}

“renegava as minhas origens, não gostava de falar espanhol e nada dos costumes"

\section{Juan:}

"além de ser imigrante, tenho que adaptar-me aos preconceitos"

57 Disponível: http://rotasdasilhas.blogspot.com.br/2010/08/o-comeco-da-viagem.html. Acessado em 20/04/2015. 
É provável que as frases que selecionei e usei para abrir este capítulo, tenham ajudado a você, leitor amigo, a lembrar-se de toda nossa jornada em torno aos imigrantes bolivianos. É verdade que são frases que causam certo desconforto, mas refletem e resumem, de maneira superlativa, o porquê eu decidi embarcar nessa viagem com eles.

Posso, então, afirmar, após todo o percurso que fizemos, embora tenha faltado espaço textual para continuar com minhas análises, que os imigrantes bolivianos não são incluídos na sociedade que os recebe. São integrados, mas não são incluídos. Estão lá, materializados fisicamente, mas são invisíveis aos olhos dos que (con)vivem com eles. No que tange à sua identidade: (des)construída! Perderam suas marcas identitárias e culturais, e precisam, literalmente, sobreviver com esse sentimento conflituoso, ambíguo e (bi)nacional. São de lá, mas, ao tempo, tem que ser daqui. São de lá, afetivamente falando, mas são daqui em sentido geográfico. Vivem esse sentimento constante de busca, de pertença.

Durante todo o meu texto, procurei visitar e revisitar minha principal e complexa inquietação, a saber, os eventos e processos sociais e linguísticos que estão entrelaçados com meus objetos de pesquisa - a inclusão dos (in)visíveis e sua (des)construção identitária.

Minha primeira pergunta de pesquisa se relacionava com as barreiras e os impactos legais, históricos e institucionais que advém do trâmite imigratório aos atores implicados no processo. Procurei no capítulo um, traçar um panorama da imigração boliviana, e de outras no Brasil, a partir duma perspectiva histórica e demográfica (BAUMAN, 2007; PATARRA, 2012; BAENINGER, 2012), dos marcos legais (PIOVESAN, 2004; ALMEIDA, 2015) e das instituições que acolhem tais imigrantes na capital paulista (CYMBALISTA, 2007; SILVA, 2008; LUCÀ, 2007). Indiquei que há, ainda, muitos entraves legais e institucionais para melhor acomodação e, consequente, inclusão dos imigrantes que chegam ao Brasil. Reconheço que, do ponto de vista político, os imigrantes bolivianos, e outros, são acolhidos no país e recebem a atenção mínima necessária para seu desembarque no país. Entretanto, há ainda um longo caminho a percorrer para que esse processo seja, de fato e direito, inclusivo.

Nos capítulos dois e três, procurei apresentar, respectivamente, o alicerce teórico que fundamentaria minha pesquisa e o trajeto metodológico que adotaria para que pudesse dar conta de responder às seguintes quatro perguntas propostas. Como, mencionei, em algum ponto do texto, prostituí-me! Procurei amparo científico em diferentes campos e teorias sociais, antropológicas e jurídicas para desenhar um panorama mais completo do meu alvo. 
Por fim, no capítulo anterior, o quarto, apresentei ao leitor, meus dados — abrigados em um grupo focal. Optei por analisá-los a partir dos pressupostos teóricos de duas teorias linguísticas críticas: a Análise de Discurso Crítica (FAIRCLOUGH, 2001) e, mais especificamente, a Abordagem Crítica de Ideologia (THOMPSON, 2002a); e, a Teoria da Avaliatividade (MARTIN; WHITE, 2005) como parte do quadro teórico mais amplo da Linguística Sistêmico-Funcional (HALLIDAY; MATTHIESSEN, 2004).

Ancorado na Análise de Discurso Crítica e na Abordagem Crítica de Ideologia, procurei responder às perguntas de pesquisa dois e três, que se relacionam como meu primeiro objeto de pesquisa, a saber, a inclusão dos (in)visíveis. Nelas, almejei entender que atitudes são reveladas pelas escolhas linguísticas ao falar da questão da inclusão e (in)visibilidade no caso dos imigrantes bolivianos, assumindo que há desníveis e disparidades marcadamente ideológicos, excludentes e discriminatórios; e, qual a profundidade do tema da exclusão e invisibilização dos bolivianos no bairro.

Demonstrei, com os dados apresentados: fotos, videoclipe, narrativas escritas e visuais, que os imigrantes bolivianos, neste bairro paulistano, sofrem processo de exclusão social velada e sustentada por uma ideologia que penetra em cada um deles, de modo a que eles mesmos sejam os portadores desses conceitos equivocados a respeito dos estrangeiros. Tal ideologia age como um vírus que os corrompe e entorpece seus sentidos, chegando ao ponto de eles acharem que devem ser agradecidos por estarem aqui (comentário de Carolina, nota de rodapé $\mathrm{n}^{\mathrm{o}} 42$ ). Essa postura obriga-os, inconscientemente, a fazer escolhas de estruturas linguísticas eufemizadas e modalizadas, como se estivessem pedindo desculpas, quando afloram sentimentos de exclusão ou quando são sentidos os efeitos do preconceito a que são submetidos diariamente na comunidade e pelo seus pares.

Em um segundo momento de minhas análises, busquei responder às perguntas de pesquisa quatro e cinco, a saber: a) que imagens representativas de seu país de origem são mantidas e que outras se manifestam e se transmutam à construção da [nova] identidade coletiva e (bi)nacional?; e, como é (des)construída sua identidade a partir da decisão de sair de sua terra natal?. Ancorei-me na Teoria da Avaliatividade, mais especificamente, no subsistema de atitude que se presta a revelar os sentimentos de afeto e julgamento dos imigrantes quando confrontados com questões identitárias. Tal suporte teórico está abrigado na metafunção interpessoal na Linguística Sistêmico-Funcional. 
Procurei demonstrar, amparado por um videoclipe musical e por uma letra da música e pelos comentários feitos pelos participantes da pesquisa, como sua identidade é profundamente afetada por esse trâmite imigratório. Como ela é envolvida num processo, quase ininterrupto, de construção, des-construção e re-construção; processo que chamo de (des)construção ao longo do meu texto. Destaquei que é como se eles, os imigrantes bolivianos, estivessem numa dinâmica cruel, todo o tempo ocupados com juntar seus 'cacos' identitários e tentar reuni-los, como que em uma peça única, sem fissuras. Os sentimentos afetivos, os julgamentos, as expectativas e a atitude, de um prisma mais geral, são marcados por esse processo identitário (des)construído e pela constante busca de uma pertença identitária. Mas, o máximo que logram é construir um mosaico, ora apreciado ora rejeitado.

Portanto, o meu desejo e o que concluo, após navegar por essas águas revoltas e em sua companhia, leitor amigo, é o mesmo que propus no resumo que abre os trabalhos deste texto: "que todos os imigrantes, sejam eles de que país ou estrato social forem, devem receber um trato social verdadeiramente inclusivo, humanizado e igualitário, balizado nos direitos de universalidade e individualidade, e despojado de paradigmas excludentes onde quer que imigrem, e enquanto houver fronteiras criadas pelo homem, e que apenas servem para a triste separação do homem de outro homem, do ser humano, do próprio ser humano."

\subsection{Proposições}

“Não basta saber, é preciso também aplicar. Não basta querer, é preciso também agir”.

Mencionei, em outro ponto de meu texto, que meus dados, a serem analisados nesse texto, eram apenas uma mostra representativa de todo o meu corpora que, por uma questão de espaço textual, não seria possível analisá-lo em sua totalidade e ampará-lo em todas as teorias linguísticas de cunho crítico e social que havia almejado na concepção de minha pesquisa.

Pois bem, há porões de dados! Há, pelo menos, dois terços mais de corpora que merecem atenção, e que servirão, em pesquisas futuras, para ampliar o entendimento das questões aqui propostas. Portanto, alisto a seguir outras partes do corpora, que podem ser usados em pesquisas futuras, e que teorias, entendo eu, podem contribuir para sua análise. 
Espero, assim, com esse entendimento mais apurado e mais aprofundado poder propor ações afirmativas em favor dos imigrantes bolivianos em São Paulo. Por ações, me refiro a instrumentalizá-los, empoderá-los para que possam (auto)emancipar-se e transformar sua história de modo mais crítico e, assim, aliviar a dor da exclusão, da (des)construção de sua identidade, das injustiças a que são submetidos, da desigualdade a que são expostos.

Dentre tais ações, entendo, como linguista, que a primeira delas deve estar relacionada com a língua(gem) e, mais especificamente, com o domínio da língua portuguesa. Esta, concebo eu, pode contribuir para o empoderamento e a emancipação social de tais imigrantes acolhidos no Brasil e auxiliá-los na construção de significados, de identidades sociais e de conhecimentos (com)partilhados (SOUSA SANTOS, 2007).

Para tanto, tal ensino de Português deve pautar-se por uma abordagem (inter)cultural e de cunho crítico, nos termos propostos por Rocha (2012), Maher (2007b) e Kubota (2004), a fim de propiciar a formação cidadã integral de tais imigrantes bolivianos, e outros, que se encontram num entre-lugar no país de acolhimento (BHABHA, 1998).

Dada a a complexidade e a dinâmica da movimentação de/entre povos no afronteiriço mundo contemporâneo, as práticas sociais de circulação e as novas relações entre os nacionais e os imigrantes também são cíclicas e continuamente (re)configuradas, e com prejuízo para os imigrantes, em muitos casos. Decorre daí minha percepção de que o ensino de Português à luz dos estudos dos multiletramentos, por exemplo, por um viés crítico, reflexivo, dialógico - e dialético, por vezes - contribuirá para a inclusão social de tais imigrantes que são inúmeras vezes privados de protagonismo e prestígio na sociedade local (COPE; KALANTZIS, 2000; ROJO, 2009a).

Creio que, com este estudo adicional e mais aprofundado, poderei contribuir para uma melhor compreensão do tema em tela e, quiçá, para a proposição de uma política afirmativa, no sentido mais amplo do termo, em benefício dos imigrantes no Brasil, que vivem numa mescla de alegrias e de privações sofridas na pátria adotada (ROJO, 2006).

Alisto, a seguir, duas teorias linguísticas, também de cunho crítico, que podem ser úteis na análise de, pelo menos, dois outros conjuntos de dados, coletados por diferentes instrumentos de pesquisa e que poderão, no futuro, ser úteis, após analisados.

Vamos as teorias que sugiro e seus respectivos conjuntos de dados. 


\subsection{1. (Nova) Pragmática em contextos de imigração}

A primeira teoria que sugiro é a (Nova) Pragmática, pois está se relaciona com a pesquisa e o estudo da língua(gem) em seu contexto de uso. Entendo que esta teoria ancoraria, com bastante suficiência, uma pesquisa valorativa realizada com os participantes no grupo focal. Nesta pesquisa, procurei averiguar o entendimento, e o posicionamento, dos imigrantes bolivianos, no que tange à inclusão social, a partir da separação entre os construtos: aceitação, adaptação, integração, segregação e exclusão. Abordei essa temática com eles pensando em eventos sociais que participam e nos processos linguísticos envolvidos. Realizei a referida pesquisa fundamentado no conceito transdisciplinar de representação social, trabalhando os pontos de convergência e divergência nas obras de Denise Jodelet $(1985,1989 a, 1989 b)$ e Serge Moscovici $(1978,1988,1989)$. Descrevo, a seguir, o porquê da eleição da teoria em tela para análise desse corpus.

A Teoria (Nova) Pragmática "investe no potencial crítico [e interdisciplinar] que a noção de práxis social oferece para a compreensão da língua" (SILVA, et. al. 2014, p. ii). As palavras, em sua significação comum, assumem muitas vezes outros significados distintos no uso da língua e, mais recentemente, o campo de estudo da (Nova) Pragmática passou a englobar o estudo da linguagem comum e o uso concreto da linguagem, enquanto a semântica e a sintaxe constituem a construção teórica (RAJAGOPALAN, 2010). A primeira, portanto, estuda os significados linguísticos determinados não exclusivamente pela semântica proposicional ou frásica, mas aqueles que se deduzem a partir de um contexto social, discursivo e situacional.

O termo pragmática é derivado do grego pragma, significando coisa, objeto, principalmente o sentido de algo feito ou produzido, sendo que o verbo pracein, significa precisamente agir, fazer. O uso do termo pragmática como ramo da linguística teve início com Charles Morris e Mario Bertolini, em 1938, significando o estudo da linguagem em uso. Rudolf Carnap, que trabalhara com Morris em Chicago, definiu-a como sendo a relação entre a linguagem e seus falantes. Portanto, trata-se de uma visão filosófica que adota uma posição anti metafísica, no sentido de que não é aceitável a concepção de uma realidade supra sensível, e em que os estudos da linguagem devem ser realizados numa perspectiva pragmática, enquanto prática social concreta, a partir da interação entre os falantes, do 
contexto de uso, dos elementos socioculturais pressupostos pelo uso, dos objetivos, dos efeitos e das consequências desses usos.

Jacob L. Mey declara que "não podemos descrever a linguagem e seu uso fora do contexto desse uso, ou seja da sociedade na qual ela é usada" (MEY, 1985, p. 11) e acrescenta que não é possível estudá-la a partir de um certo "fetichismo pela exclusão de fatos do contexto" (MEY, 2003). Sendo assim, a visão pragmática se distingue na sociedade pela pluralidade de discursos que reflete sua complexidade externa. Alinho com Bakhtin, pois:

[Trata-se de] um diálogo de forças sociais percebido não somente na coexistência estática, mas também como um diálogo de diferentes tempos, épocas e dias, um diálogo que está sempre morrendo, vivendo, nascendo: a coexistência e o tornar-se são aqui fundidos numa unidade concreta, indissolúvel, que é contraditória, multifacetada e heterogênea (BAKHTIN, 1988, p. 159).

Na contramão da teoria pragmática, está a visão que coloca a linguagem fora do seio social e, portanto, privilegia o falante individual como o pomo central, introspectivo e narcisista. Esta tem sua gênese no século XVIII, na concepção de William Dwight Whitney (1827-1894), e é mais fortemente divulgada através dos estudos de Noam Chomsky com sua teoria do falante-ouvinte ideal marginalizando, sendo assim o aspecto social que é considerado apenas como "fato contingente" (CHOMSKY, 1975, p. 71). Essa visão divergente é completa e claramente oposta ao pensamento de inúmeros estudiosos da linguagem como Halliday, Wittgenstein, Vygotsky, Mey, etc. (RAJAGOPALAN, 2010). Bourdieu apresenta o motivo de tal divergência:

Quando tratamos a língua como um objeto autônomo, aceitando a separação radical que Saussure fez entre linguística interna e externa, entre a ciência da língua e a ciência dos usos sociais da língua, estamos condenados a procurar pelo poder das palavras dentro das palavras, i.e., onde não iremos achar (BOURDIEU, 1991, p. 107).

Esse movimento fundacional de alojar a linguagem fora do seio social resulta em exclusão dos falantes que não podem ser classificados como o ideal. O resultado, posso dizer, lamentável e trágico para os estudos linguísticos, foi descrito por Alastair Pennycook: 
Enfatizando cada vez mais os mecanismos internos da língua, como se eles pudessem ser entendidos separadamente dos seus usuários e contextos sociais, a linguística desenvolveu uma confiança dogmática em sua própria capacidade de descrever (em vez de prescrever) a língua (PENNYCOOK, 2004, p. 41).

Destaco que a linguística tradicional, de acordo com as postulações chomskyanas, apenas dá força para um caráter segregacionista da língua, se usado dessa forma e para esse fim. Esse monolitismo imperialista propicia o desprezo pela diversidade linguística e cultural e serve para homogeneização medíocre do pensamento com impacto negativo profundo nos imigrantes bolivianos, pois eles são, no cenário da comunidade local, impedidos de existir, coexistir e exprimir-se na língua do seu coração ou da sua mente, no âmbito público. A teoria Pragmática, conforme definida acima, opera no seio social e diz respeito à língua(gem) em uso, nos diferentes contextos, mostrando sua função simbólica, a dimensão política, ideológica, social e étnica, não se tratando somente de ser purista e defender a língua do Brasil, no caso em pauta, como país acolhedor, mas de respeitar profundamente a língua do outro - a do imigrante boliviano, visto que eles investem valores afetivos e estéticos no uso que fazem de sua língua materna e da do país que os recebeu.

Dante Alighieri, in De Vulgari Eloquentia, livro I, seção 6 menciona que “[...] as relações humanas se fazem em vários e diferentes idiomas, o que faz com que muitos não sejam compreendidos por muitos". Maria Antonieta Celani, ao falar dessa visão de Dante, apresenta a questão da diversidade e da diferença no contexto de uso da língua quando diz que esta é:

[...] para quem "a pátria é o mundo, assim como o mar é para os peixes". É enxergar além. Além de seu redor, sem menosprezá-lo; além de seus valores, sem perdê-los; além de seu país, sem abandonar sua cultura. É entender a diferença e a diversidade, por meio de uma experiência de imersão na sabedoria distintiva de uma outra cultura como espaço para crescimento. É engajar-se com a diferença (CELANI, 2004, p. 121).

Suas palavras encontram eco em David Crystal, que discute essa questão no prefácio de sua Cambridge Encyclopedia of Language (1987: vii):

Todas as pessoas têm o direito de usar sua língua materna, de aprender uma segunda língua, de receber tratamento especial quando sofrem de um distúrbio de comunicação [...] mas em muitas partes do mundo esses direitos estão ausentes ou não são devidamente garantidos. 
Cunningham (2003) fala do papel que as línguas podem efetivamente assumir na promoção da paz. O que não é possível materializar-se no caso dos imigrantes bolivianos em São Paulo dada não aceitação de sua língua materna por parte da comunidade local.

Pelos motivos abordados entro no terreno da (Nova) Pragmática com uma concepção compromissada, engajada e crítica (SILVA, et.al., 2014), em que os personagens sociais, juntos, fazem o tecido da sociedade, e o texto societal é o resultado da representação do entendimento do personagem acerca dessa organização, pois, em cada mundo social, existem dissonâncias de vozes como as que não soam em uníssono, ou estão fora de tom, e as que sequer conseguem transpor o limiar da escuta (MEY, 2001). Relacionando à minha pesquisa $\mathrm{o}$ pensamento de Jacob Mey, eu acrescentaria que há ainda as vozes que conseguem reproduzir um som social mais próximo do aceito em dado cenário social, conforme demonstrarei na análise de dados de alguns dos imigrantes bolivianos que são participantes do grupo focal, ilustrando que eles estão em diferentes níveis de encaixe social.

Jacob Mey alerta ainda para o fato de a sociedade ser um depósito de lixo de desigualdades sociais, o que nos obriga, então, a primeiro limpá-la, usando a língua(gem) em uso como nossa ferramenta (MEY, 2001). Os que estão no poder na comunidade onde se inserem os imigrantes bolivianos trabalham para que a regra, a lixeira de desigualdades, se perpetue. Trata-se de brasileiros que recebem tais imigrantes e, em sua situação de poder, usam o valor dos aluguéis de imóveis em péssimas condições, por exemplo, para manter os imigrantes sob sua custódia simbólica. Trabalham concomitantemente para velar seu poder, mantê-lo encoberto numa falsa sensação de acolhimento por meio de um discurso de cunho familiar e fraternal para que tais imigrantes não se dêem conta da opressão a que são submetidos e o aceitem como sendo uma benção da sociedade acolhedora. Sobre isso lemos em Bourdieu:

O discurso [...] deve contribuir não somente para romper com a adesão ao mundo do senso comum, professando publicamente a ruptura com a ordem ordinária, mas também produzir um novo senso comum e nele introduzir as práticas e as experiências até então tácitas ou recalcadas de todo um grupo, agora investidas da legitimidade conferida pela manifestação pública e pelo reconhecimento coletivo [desse grupo] (BOURDIEU, 1996, p. 119). 
Em outras palavras, Bourdieu destaca que é como se essa prática perpetrada pelos brasileiros recebesse o aval do grupo e fosse investida de legitimidade e reconhecimento coletivo, como se tal reconhecimento e legitimidade beneficiasse, de fato, aos imigrantes.

Portanto, visto que a língua em seus múltiplos contextos de uso pode servir tanto como instrumento de opressão quanto de libertação, objetivo desvelar essa realidade, descobrir a manipulação existente e desconstruir a noção/ilusão de que os imigrantes bolivianos são usuários independentes da língua, além da perigosa armadilha do consumo ilimitado do manipulado texto societal (MEY, 2001).

Grande parte das desigualdades e maldades que são perpetradas no mundo moderno ocorrem na/pela língua(gem). E não seria diferente no caso dos imigrantes bolivianos, pois, através da linguagem, eles sofrem discriminação ora de forma velada ora às claras. Um exemplo disto são as leis que deveriam supostamente promover a igualdade e o bem-estar de todos, inclusive dos imigrantes, mas, que são, muitas vezes, ora ocas de sentido e aplicabilidade ora omissas ora, pior ainda, atribuem culpa às vítimas de abusos. Embora veicule-se aos quatro cantos um discurso de inclusão como sendo a panacéia das gigantescas ondas de discriminação que se avolumam no mar da sociedade, não é exatamente o que se nota no caso dos imigrantes bolivianos, pois, embora identifiquem-se esporadicamente casos de inclusão, não há a adoção de ações duradouras e benéficas em favor deles.

\subsubsection{Realismo Crítico: emancipação e transformação do imigrante}

Além da Teoria (Nova) Pragmática, entendo que o Realismo Crítico também pode oferecer uma contribuição valiosa na análise de um segundo conjunto de dados, não contemplados nas análises desta pesquisa. Trata-se de um entrevista semi-estruturada de dez perguntas cujo objetivo se relacionava com o objeto de pesquisa: identidades. Esta entrevista foi realizada de forma escrita e também gravada em áudio e vídeo, após discussões bastante profícuas sobre a condição dos imigrantes bolivianos em São Paulo. Assim, tanto o material escrito quanto o material audiovisual, fornecerão material abundante para entender a questão da (des)construção identitária visando à emancipação e transformação dos imigrantes.

Para tanto, vejo o Realismo Crítico como uma teoria robusta o suficiente para ampliar o entendimento das questões em pauta, pois ... 
... o Realismo Crítico enquanto filosofia de caráter emancipatório na prática e que visa transformações sociais, servirá para uma reflexão teórico-metodológica e para a compreensão da relação transformacional entre a sociedade local e os imigrantes bolivianos:

Meu ponto de vista é que aquele tipo especial e qualitativo de libertação que é a emancipação, e que consiste na transformação, na auto-emancipação dos agentes envolvidos (BHASKAR, 1998, p. 462).

Ampliando a citação de Bhaskar, Papa (2009, p. 111) diz que "a emancipação significa libertação e a auto-emancipação pressupõe transformação", ou seja, os agentes envolvidos no processo, em especial os afetados negativamente por essa relação social dialética, devem ser conduzidos nesse processo-duplo: emancipação e transformação. Entretanto, para que isto ocorra é necessário "compreender as camadas mais profundas da realidade [social], nas quais se escondem os determinantes causais, os fenômenos e as aparências dos eventos a serem desvelados" (PAPA, 2009, p. 113).

Portanto, o Realismo Crítico assume um caráter importante nesta pesquisa por causa de seu aspecto emancipatório e subversivo, ou seja, se trata de uma alternativa ao conformismo empírico que se contenta apenas com a identificação e descrição das realidades sociais sem a vocação para que haja transformação da mesma, num sentido materialista.

A partir de algumas perguntas numa entrevista semi-estruturada dentro do grupo focal, continuo abordando com os imigrantes bolivianos que participaram dessa pesquisa o tema: inclusão social. Procuro, com esta ferramenta adotada, extrair dos participantes da pesquisa o que pensam do tema em tela e se estes conseguem ver as intenções reais da comunidade local em sua interação diária e se tais intenções/ações são, de fato, inclusivas socialmente.

Bhaskar e Callinicos (2003) destacam que o mundo tem de estar constituído como realidade independente da investigação científica enquanto tal, e que a intenção do Realismo Crítico é contribuir para a solução de alguns problemas do mundo real, pois este está dilacerado por um mundo teórico fundado na abstração que se configura como pouco relevante para entender a realidade social e suas ontologias.

Para ampliar minha compreensão do Realismo Crítico e sua relação com esta pesquisa destaco que para Bhaskar (1989) o mundo real, formado de estruturas naturais e sociais, existe independentemente de nossa existência, nosso conhecimento dele, nossa percepção e concepção individual e coletiva sobre ele. Assim, quando penso em sociedade nesse prisma, 
entendo que a mesma possui uma relação de inter-dependência com a ação humana configurando-se caracteristicamente pela mutabilidade e estratificação, pois:

Os realistas críticos assumem uma "ontologia estratificada", segundo a qual o mundo é um sistema aberto, constituído por diferentes domínios (real, actual e empírico) e diferentes estratos que operam simultaneamente (físico, químico, biológico, econômico, semiótico etc.), e cada qual com suas estruturas distintivas e mecanismos gerativos [de poder], causa efeitos imprevisíveis no mundo (RAMALHO, 2009, p. 2).

Assim, entendo que, na concepção do Realismo Crítico, o mundo não é constituído apenas pelo domínio empírico, mas por três domínios ontológicos como destacam estudiosos do tema como Bhaskar (1989; 1998), Ramalho (2009) e Papa (2009). Há o domínio do real que se relaciona com a existência das estruturas e mecanismos de poder; já no domínio do actual é onde podemos verificar os resultados de tais poderes em ação; e, por fim, o terceiro domínio, o empírico, tem a ver com as experiências afetivas vividas pelos atores sociais.

Em outras palavras:

\footnotetext{
“o real é o domínio dos poderes causais e o actual é o domínio dos eventos em que se acionam esses poderes, o empírico, por sua vez, é o que se percebe da ativação desses poderes no domínio dos eventos experienciados" (RAMALHO, 2009, p. 4).
}

Outro aspecto relevante do Realismo Crítico é que para essa vertente teórica não é possível se ter acesso direto ao domínio do real, das estruturas e mecanismos de poder que operam em seu interior, a não ser através de nosso conhecimento do actual e do empírico. Por essa razão, entendo eu, baseado nesse viés, que se perpetuam injustiças sociais, pois o domínio do real opera às escondidas, às escuras. Esse entendimento também ajuda a explicar porque os imigrantes bolivianos são excluídos na/pela língua(gem), dado o seu domínio parco das práticas sociais locais. Vejo, portanto, que os pressupostos teórico-metodológicos do Realismo Crítico serão úteis para desvelar as estruturas do mundo real, em que estão inseridos os imigrantes bolivianos, e fornecer-lhes os subsídios necessários para a transformação da estrutura social (re)organizando-a de forma mais equitativa.

Essa transformação da estrutura social ocorre(rá) num movimento de duplo sentido, pois os mesmos atores sociais envolvidos no processo são capazes de agir e reagir nessa 
estrutura, articulá-la e rearticulá-la, produzi-la e reproduzi-la, gerando efeitos (im)previsíveis. Nesse respeito, há um movimento interessante entre os imigrantes bolivianos em São Paulo, pois uma vez que não têm acesso a estrutura social vigente, ao mundo real, (re)criam o seu próprio a partir do modelo que trazem de sua terra natal. Inserem nessa (nova) estrutura, que se funde à primeira, os seus conterrâneos que são assujeitados por meio de mecanismos de poder - confirmando assim os princípios que regem o Realismo Crítico, conforme discuto.

Assim, meu intuito principal em relação a inserção do Realismo Crítico como teoria neste texto, pode ser sintetizado nas palavras de Sayer quando ele observa que:

[embora] o realismo crítico endosse uma gama relativamente ampla de métodos de pesquisa, investigações orientadas pela proposta teóricometodológica baseiam-se em análises de mecanismos causais e de seus efeitos potenciais em determinados contextos [sociais] (SAYER, 2000, p. 20).

Arremato, então, com as palavras da Profa. Dra. Viviane Ramalho:

\begin{abstract}
A tarefa da pesquisa social orientada pelo RC é, a partir dos domínios actual e empírico, investigar mecanismos causais que operam em nível real, gerando efeitos particulares em sociedades, com atenção voltada, sobretudo, para causas e efeitos envolvidos em relações de poder. Esta abordagem parte da abstração de eventos concretos da vida social, com o objetivo de compreender a natureza pré-estruturada da vida social, e retorna à análise de eventos, de ações e processos à luz desse conhecimento [... ] A tarefa emancipatória do RC seria identificar compreensões sociais falsas e, conseqüentemente, ações falsamente embasadas, e mostrar que estas compreensões e ações devem ser mudadas (RAMALHO, 2009, p. 7, 8).
\end{abstract}

Enfim, espero ter despertado em você, leitor amigo, suficiente curiosidade para que, quiçá, possamos criar um novo roteiro de viagens, de navegação, por essas águas tão turbulentas, que é o tema proposto em minha pesquisa, mas que, ao mesmo tempo, pulula de riquezas, de alimentos, de nutrientes para pesquisadores, como nós, que ansiamos poder empapar-nos do assunto. Assim, poderemos não apenas identificá-los e descreve-los, mas também, intervir propositivamente e aliviar a dor das vidas alheias que nos propomos estudar.

Quero que saiba, leitor amigo, que foi um enorme prazer navegar com você! 


\title{
REMATE
}

\section{O desfecho da jornada: hora do desembarque no porto}

\author{
Foto 7 - É chegado o desenredo
}

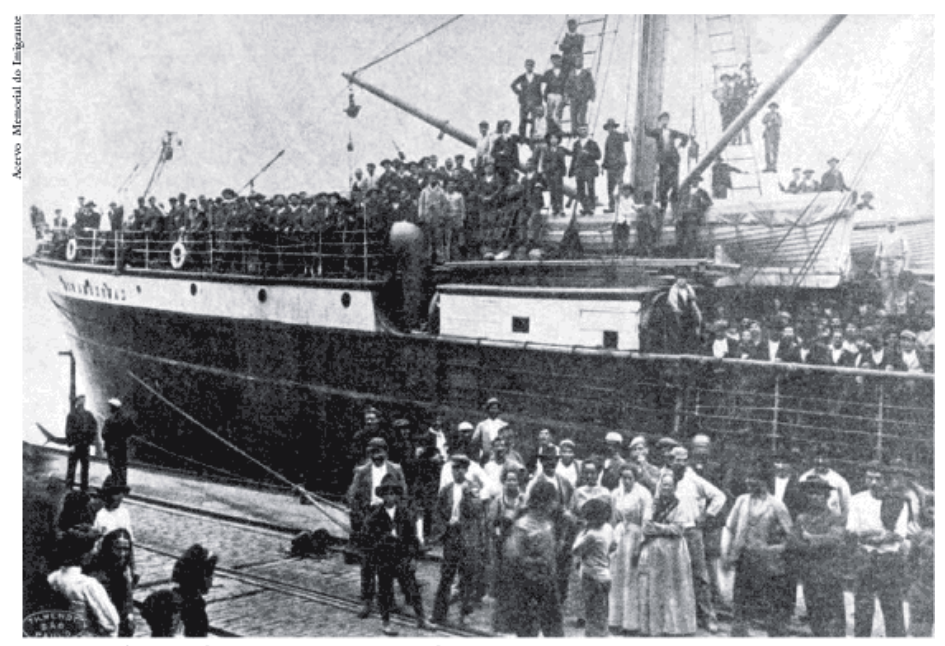

Desembarque de imigrantes no Porto de Santos (SP), 1907.

Fonte: Google 58

“A mente que se abre a uma nova ideia jamais voltará ao seu tamanho original”.

Aproprio-me desta frase para rematar esta dissertação, ou melhor dito, para desembarcar em mais um cais da vida no desfecho dessa profícua, bem servida e enriquecedora jornada. Uma vez aberta minha mente em relação ao tema objeto deste texto, anseio poder fazer-me ao mar novamente para continuar navegando por essas águas, ora calmas ora raivosas. Que se tornem proféticas as palavras de Einstein e que minha mente jamais volte ao seu tamanho original enquanto navio de pesquisa.

Sendo assim, ...

58 Disponível: https://intelectuaisdahistoria2.wordpress.com/2013/03/26/desembarque-de-imigrantes-no-portode-santos-sp-1907-gif/ Acessado em 20/04/2015. 
... Despeço-me desta hora no corpo deste navio

Que vai saindo. É um tramp-steames inglês" Muito sujo, como se fosse um navio francês, Com um ar simpático de proletário dos mares, E sem dúvida anunciado ontem na última página das gazetas.

Lá [vou eu] deixando o lugar defronte do cais onde estou. Lá [vou eu] tranquilamente, passando por onde as naus estiveram. Outrora, outrora... Para Cardiff? Para Liverpool? Para Londres? Não tem importância.

Passa, lento vapor, passa e não fiques Passa de mim, passa de minha vista, Vai-te de dentro de meu coração

— Fernando Pessoa

E, a você, leitor amigo, anuncio ...

O Captain! my Captain! our trip is done, The ship has weather'd every rack, the prize we sought is won, The port is near, the bells I hear, the people all exulting, While follow eyes the steady keel, the vessel grim and daring; 


\section{REFERÊNCIAS}

ADAMS, J. T. The Epic of America. New York: Blue Ribbon Books, 1931.

ADORNO, T.W. Dialética Negativa. Rio de Janeiro: Jorge Zahar, 2009.

Educação e Emancipação. 4. ed. Tradução de Wolfgang Leo Marr. São

Paulo: Paz e Terra, 2006.

; HORKHEIMER, M. Dialética do Esclarecimento: Fragmentos Filosóficos.

Rio de Janeiro: Jorge Zahar, 1985.

AHLERT, A. Exclusão Social versus Qualidade Ética da Educação. In: BONETI, L.W. (Coord.) Educação, Exclusão e Cidadania. Ijuí: Editoria Unijuí, 1997, p.15-40.

ALENCAR, C.N. Identidade e Poder: Reflexões Sobre a Linguística Crítica. In: RAJAGOPALAN, K.; FERREIRA, D.M.M. (Orgs.). Políticas em Linguagem: Perspectivas Identitárias. São Paulo: Mackenzie, 2006, p. 39-60.

ALMEIDA, P. Comissão de Relações Exteriores e de Defesa Nacional. Projeto de Lei $\mathbf{n}^{\mathbf{o}}$ 5.655/2009. Disponível em: http://www.camara.gov.br/proposicoesWeb/fichadetramitacao? idProposicao=443102. Acessado em 21/01/2015.

ALTHUSSER, L. Aparelhos Ideológicos de Estado: Notas Sobre os Aparelhos Ideológicos de Estado. Rio de Janeiro: Geral, 1985.

ANDRADE, P.; CALDERÓN, M.; SILVA, C.; VIDAL, M. La Construcción de la Identidad Discursiva de Personas en Situación de Calle a Partir de la Relación Yo-Ellos. In: PARDO, M.L. (Org.) El Discurso Sobre la Pobreza en América Latina. Santiago: Frasis, 2008, p. 123-143.

AMORIM, A. A Contribuição da Categoria de Habitus para a Reflexão Sobre a Migração Internacional. In: TEIXEIRA, P. E.; BRAGA, A.M.C.; BAENINGER, R. (Org). Migrações: Implicações Passadas, Presentes e Futuras. São Paulo: Cultura Acadêmica, 2012, p. 36-48. ANDRÉ, M.E.D.A. Etnografia da Prática Escolar. 3 ed. São Paulo: Papirus. Série Prática Pedagógica, 1995.

ARENDT, H. As Origens do Totalitarismo. Rio de Janeiro: Editora Documentário, 1979. A Condição Humana. Rio de Janeiro: Forense Universitária, 1999.

ARISTÓTELES. Metafísica. São Paulo: Loyola, 2002. 
ARZABE, P. H.M. O Direito à Proteção Contra a Pobreza e a Exclusão Social. 309 f. Tese (Doutorado). Universidade de São Paulo, São Paulo, 2001.

ASSUNÇÃO, C.A.R. A Ideologia na Legislação da Educação Inclusiva. 212 f. Dissertação (Mestrado). Instituto de Letras, Universidade de Brasília, Brasília, 2007.

AZUAGA, L.; AVELAR, A. Teoria da Avaliatividade: Breve Apresentação. Lisboa, Centro de Estudos Anglísticos, 2003.

BAENINGER, R. O Brasil no Contexto das Migrações Internacionais na América Latina. In: BRITO, F.; BAENINGER, R. (Org.). População e Políticas Sociais no Brasil: os Desafios da Transição Demográfica e das Migrações Internacionais. Brasília: Centro de Gestão e Estudos Estratégicos, 2008.

. (Org.). Imigração Boliviana no Brasil. Campinas: Núcleo de Estudos de População — Nepo/Unicamp; Fapesp; CNPq; Unfpa, 2012, 316 p.

Fases e Faces da Migração em São Paulo. Campinas, SP: Núcleo de Estudos de População — Nepo/Unicamp, 2012, 146 p.

. Migrações Internacionais e Cidadania. In: TURRA, C. M.; CUNHA, J.

M. P. (Org.) População e Desenvolvimento em Debate: Contribuições da Associação Brasileira de Estudos Populacionais. Belo Horizonte: ABEP, 2012, p. 93-95.

BAKHTIN, M. (VOLOSHINOV). Marxismo e Filosofia da Linguagem: Problemas Fundamentais do Método Sociológico na Ciência da Linguagem. Trad. Michel Lahud e Yara Frateschi Vieira. 4. ed. São Paulo: Hucitec, 1988.

Estética da Criação Verbal. São Paulo: Martins Fontes, 2000.

BARTHES, R. Element of Semiology. New York: Hill and Wang, The Noonday Press, 1967. BAUER, M.W.; GASKELL, G. Towards a Paradigm for Research on Social Representations. Journal for the Theory of Social Behaviour, 29 (2), 1999, p.163-186.

; AARTS, B. A Construção do Corpus: um Princípio para a Coleta de Dados Qualitativos. In: BAUER, M.W.; GASKELL, G. (Orgs.). Pesquisa Qualitativa com Texto, Imagem e Som: um Manual Prático. $11^{\text {a }}$ ed. Petrópolis, RJ: Vozes, 2013, p. 39-89.

BATISTA JUNIOR, J.R.L. Os Discursos Docentes Sobre Inclusão de Alunas e Alunos Surdos no Ensino Regular: Identidades e Letramentos. 151 f. Dissertação (Mestrado). Instituto de Letras, Universidade de Brasília, Brasília, 2008. 
BAUMAN, Z. Towards a Critical Sociology: an Essay on Common Sense and Emancipation. Londres: Routledge, 1976.

. Globalização: as Conseqüências Humanas. Trad. Marcus Penchel. Rio de Janeiro: Jorge Zahar, 1999.

. Modernidade e Ambivalência. Rio de Janeiro: Jorge Zahar, 1999.

. Comunidade: a Busca por Segurança no Mundo Atual. Rio de Janeiro: Jorge

Zahar, 2003.

Tempos Líquidos. Rio de Janeiro: Jorge Zahar, 2007.

. Capitalismo Parasitário. Trad. Eliana Aguiar. Rio de Janeiro: Jorge Zahar,

2010.

. Vida à Crédito: Conversas com Citlali Rovirosa-Madrazo. Trad. Alexandre

Werneck. Rio de Janeiro: Jorge Zahar, 2010.

BENTHAM, J. O Panóptico ou a Casa de Inspeção. In: SILVA, T. T. (Org.). O Panóptico. Belo Horizonte: Autêntica, 2000.

BERnSteIN, B. Pedagogy Symbolic Control and Identity: Theory, Research, Critique. London: Taylor and Francis, 1996b.

BHABHA, H. O Local da Cultura. Belo Horizonte: Ed. UFMG, 1998.

BHASKAR, R. The Possibility of Naturalism. Hemel Hempstead: Harvester Wheatsheaf, 1989.

. Critical Realism: Essential Readings. In: ARCHER, M. et. al. Centre for Critical Realism. London: Routledge, 1998.

BÍBLIA. Português. Tradução do Novo Mundo das Escrituras Sagradas com Referências. 4 ed. Watchtower Bible \& Tract Society of New York, Inc. Brooklyn, Nova Iorque, E.U.A. e Associação Torre de Vigia de Bíblias e Tratados, São Paulo, SP, Brasil, 2006.

BONETI, L.W. Políticas Públicas, Educação e Exclusão Social. In: BONETI, L.W. (Coord.).

Educação, Exclusão e Cidadania. Ijuí: Editoria Unijuí, 1997, p.185-210.

BOURDIEU, P.; PASSERON, J-C. La Reproduction: Éléments Pour une Théorie du Système d'Enseignement. Paris: Minuit, 1973.

O Poder Simbólico. Lisboa: Difel, 1989.

. Language and Symbolic Power. Oxford: Polity Press, 1991. 
Habitus: Illusio et Racionalité. In BOURDIEU, P. Les Fins de La Sociologie Reflexive. Le Séminaire de Chicago, 1992, p.91-114.

A economia das Trocas Linguísticas. São Paulo, EDUSP, 1996.

Razões Práticas: sobre a Teoria da Ação. Campinas, SP: Papirus, 1996.

Efeitos do Lugar: a Miséria do Mundo. Petrópolis: Vozes, 1997.

O Poder Simbólico. 3 ed. Rio de Janeiro: Bertrand Brasil, 2000.

Pascalian Meditations. Cambridge: Polity Press, 2000.

. A Economia das Trocas Simbólicas. 5 ed. São Paulo: Perspectiva, 2004.

. A Dominação Masculina. 4 ed. Rio de Janeiro: Bertrand Brasil, 2005.

BRASIL. Constituição Federal do Brasil. Atualizada. São Paulo: Editora Escala, 2010.

- Ministério da Educação: Marcos Político-Legais da Educação Especial na

Perspectiva da Educação Inclusiva. Brasília: MEC/SEESP, 2010.

BRYMAN, A. Quantity and Quality in Social Research. Londres: Unwin Hyman, 1988.

BUARQUE, C. O Que é Apartação: o Apartheid Social no Brasil. Petrópolis, RJ: Vozes, 1990.

CAMPOS, M.B. A Imigração para o Brasil Segundo o Censo Demográfico de 2010. In:

Cadernos de Debates Refúgio, Migrações e Cidadania, v. 7, n. 7. Brasília: Instituto Migrações e Direitos Humanos, 2012, p. 15-20.

CANAGARAJAH, A.S. Resisting Linguistic Imperialism in English Teaching. Oxford: Oxford University Press, 1999b.

CANCLINI, N.G. Culturas Híbridas: Estratégias para Entrar e Sair da Modernidade. Trad. Ana Regina Lessa e Heloísa Pezza Cintrão. In: CANCLINI, N.G. Culturas Híbridas, Poderes Oblíquos. São Paulo: EDUSP, 1997, p. 283-350.

Diferentes, Desiguais e Desconectados. Rio de Janeiro: Editora UFRJ, 2007.

CELANI, M.A.A. Transdisciplinaridade na Linguística Aplicada no Brasil. In: SIGNORINI, I.; CAVALCANTI, M.C. (Orgs.). Linguística Aplicada e Transdisciplinaridade. Campinas, SP: Mercado das Letras, 1998.

. Chauvinismo Linguístico: uma Nova Melodia para um Velho Tema? In:

RAJAGOPALAN, K.; SILVA, F.L. (Orgs.). A Linguística que Nos Faz Falhar: Investigação Crítica. São Paulo: Parábola Editorial, 2004. 
CHOI, K.J. Além do Arco-íris: a Migração Coreana no Brasil. 150 f. Dissertação (Mestrado). FFLCH, Universidade de São Paulo, São Paulo, 1991.

CHOMSKY, N. A. Reflections on Language. New York: Pantheon Books, 1975. . Context and (Dis)ambiguity: a Pragmatic View. Journal of Pragmatics, 35

(3), 2003, p. 331-347.

CHOUliARAKI, L.; FAIRCLOUGH, N. Discourse in Late Modernity: Rethinking Critical Discourse Analysis. Edinburgh: Edinburgh University, 1999.

COPE, B.; KALANTZIS, M. (Eds.) Multiliteracies: Literacy Learning and the Design of Social Futures. London: Routledge, 2000.

CONNERTON, P. (Ed.). Critical Sociology. Harmondsworth: Penguin, 1976.

COSTA, F.L. A Formação de Professores de Língua Inglesa e o Estágio Supervisionado: o Movimento das Experiências, Crenças e Identidades. 199 f. Dissertação (Mestrado) Instituto de Letras, Universidade de Brasília, Brasília, 2014.

COSTA-LACROUX, J. L'immigration au gré des politiques. In: FERREOL, G. (Ed.) Intégration \& Exclusion Dans la Société Française Contemporaine. Lille: Presses Universitaires de Lille, 1992, p. 59-77.

CRAWFORD, S. Iconography, Sacred and Secular: Visions of the Family. In: HODDER, I. (Org.) The Archaeology of Contextual Meanings. Cambridge: Cambridge University Press, 1987, p. 20-30.

CRYSTAL, D. The Cambridge Encyclopedia of Language. Cambridge: Cambridge University Press, 1987, p. vii.

CUnNingham, D. (s.d.) The Fédération Internationale des Professeurs des Langues Vivantes (FIPLV) and Language Rights. Mimeo, 1987.

CYMBALISTA, R.; XAVIER, I.R. A Comunidade Boliviana em São Paulo: Definindo Padrões de Territorialidade. Cadernos Metrópole, n. 17, 2007, p. 119-133, $1^{\circ}$ sem.

DELEUZE, G.; GUATTARI, F. Mil Platôs. São Paulo: Editora 34, 1997.

DEMO, P. Pobreza da Pobreza. Petrópolis, RJ: Vozes, 2003.

DERRIDA, J. Margens da Filosofia. Campinas, SP: Papirus, $1991 \mathrm{~b}$.

DESAI, Z. The Evolution of a Post-Apartheid Language Policy in South Africa: an Ongoing Site of Struggle. European Journal of Intercultural Studies. vol. 5, nº 3, 1995, p. 18-25.

DIJK, T. A van. Discurso e Poder. São Paulo: Contexto, 2015. 
DISKIN, L. Vamos Ubuntar? Um Convite para Cultivar a Paz. Brasilia: UNESCO, Fundação Vale, 2008.

EGGINS, S. An Introduction to Systemic Functional Linguistics. London: Printer Publishers, 1994/2004.

ELIAS, N.; SCOTSON, J. L. Os Estabelecidos e os Outsiders: Sociologia das Relações de Poder a Partir de uma Pequena Comunidade. Trad. Vera Ribeiro. Rio de Janeiro: Zahar, 2000. ESCOREL, S. Vidas ao Léu: Trajetórias de Exclusão Social. Rio de Janeiro: Fiocruz, 1999. EUROPEAN COMMISSION. 3rd Annual Report on Immigration and Asylum. Brussels. COM. 250 final, 2012.

FABRÍCIO, B.F. Linguística Aplicada como Espaço de Desaprendizagem: Redescrições em Curso. In: MOITA-LOPES, L.P. (Org.). Por uma Linguística Aplicada Indisciplinar. São Paulo: Parábola Editorial, 2008, p. 45-63.

FAIRCLOUGH, N. Language and Power. London: Longman, 1989.

Discourse and Social Change. Cambridge: Polity Press, 1992.

Critical Discourse Analysis: Papers in the Critical Study of Language.

New York: Longman, 1995.

Discurso e Mudança Social. Brasília: Editora UnB, 2001.

Analysing Discourse: Textual Analysis for Social Research. London;

New York: Routledge, 2003.

FERNÁNDEZ, G.E; VIEIRA, M.E. Construindo o Caminho ao Caminhar: o Ensino de Português Língua Adicional (PLA) a Crianças Imigrantes Bolivianas. In: SILVA, K. A.; SANTOS, D. T. (Orgs.). Português como Língua (Inter)nacional: Faces e Interfaces. Campinas: Pontes, 2013, p.111-126.

FERREIRA, R. Identidade, Exclusão e Consumo no Contemporâneo. In: FREITAS, A.C. (Org.) Linguagem e Exclusão. Uberlândia, MG: Edufu, 2010, p. 19-34.

FIGUEIREDO, C.J.; MASTRELLA-ANDRADE, M. Ensino de Línguas na Contemporaneidade: Práticas de Construção de Identidades. Campinas: Pontes, 2013.

FILSTEAD, W.J. Qualitative Methods: a Needed Perspective in Evaluation Research. In: COOK, T.D. \& REICHARDT, C.S. (Orgs.). Qualitative and Quantitative Methods in Evaluation Research. Beverly Hills, CA: Sage, 1979.

FLICK, U. An Introduction to Qualitative Research. Londres: Sage, 1998. 
FORRESTER, V. O Horror Econômico. Trad. Alvaro Lorencini. São Paulo: Editora Unesp, 1997.

FOUCAULT, M. L’Archéologie du Savoir. Paris: Gallimard, 1969. Microfísica do Poder. Rio de Janeiro: Graal, 1988. . A Ordem do Discurso. São Paulo: Loyola, 1996. Os Anormais. São Paulo: Martins Fontes, 2001. Em Defesa da Sociedade: Curso no Collège de France. São Paulo: Martins Fontes, 2002.

FOWLER, R. Sobre a Linguística Crítica. Linguagem em (Dis)curso - LemD, Tubarão, v. 4, n. esp, 2004, p. 207-222.

FREITAS, A.C. (Org.). Linguagem e Exclusão. Uberlândia, MG: Edufu, 2010.

GALETTI, R. Migrantes Estrangeiros no Centro de São Paulo: Coreanos e Bolivianos. In: PATARRA, N.L. (Coord). Emigração e Imigração Internacionais no Brasil Contemporâneo. São Paulo: FNUAP, 1995. . Migrações Internacionais de e para o Brasil Contemporâneo: Volumes, Fluxos,

Significados e Políticas. São Paulo em Perspectiva, v.19, no 3, 2005, p. 23-33, jul./set.

GASKELL, G. Entrevistas Individuais e Grupais. In: BAUER, M.W.; GASKELL, G. (Orgs.). Pesquisa Qualitativa com Texto, Imagem e Som: um Manual Prático. 11 a ed. Petrópolis, RJ: Vozes, 2013, p.64-89.

GEE, J.P. et al. The New Work Order, Behind the Language of the New Capitalism. Colorado: Westview Press, 1996.

GIBBS, G. Análise de Dados Qualitativos. Porto Alegre: Artmed, 2009.

GIDDENS, A. Modernidade e Identidade. Rio de Janeiro: Jorge Zahar, 2002.

GORDON, W.; LANGMAID, P. Qualitative Market Research: a Practitioner's Guide. Aldershot: Gower, 1988.

GRAMSCI, A. Americanismo e Fordismo. São Paulo: Martins Fontes, 1978. . Concepção Dialética da História. Trad. Carlos N. Coutinho. Rio de Janeiro: Civilização Brasileira, 1995.

GUEBERT, M.C.C. Inclusão: uma Realidade em Discussão. Paraná: Intersaberes, 2012. 
HABERMAS, J. Knowledge and Human Interests. Cambridge: Polity Press, 1987.

The Structural Transformation of the Public Sphere: an Inquiry into a

Category of Bourgeois Society. Cambridge: Polity Press, 1992.

. Inclusão: Integrar ou Incorporar? Sobre a Relação entre Nação, Estado de

Direito e Democracia. Novos Estudos CEBRAP, São Paulo, nº 52, 1998.

A Inclusão do Outro: Estudos de Teoria Política. Trad. Georger Sperber e

Paulo Astor Soethe. São Paulo: Loyola, 2002.

HALL, S. A Identidade Cultural na Pós-Modernidade. Rio de Janeiro: DP\&A, 2005.

Da Diáspora: Identidades e Mediações Culturais. Belo Horizonte: Editora UFMG, 2008.

HALLIDAY, M.A.K. El Lenguaje como Semiótica Social: La Interpretación Social del Lenguaje y del Significado. Trad. Jorge Ferrero Santana. México: Fondo de Cultura Económica, 1982.

Systemic Background. In: BENSON, J. D.; GREAVES, W. S. (Eds.).

Systemic Perspectives on Discourse. Norwood, NJ: Ablex, 1985b, p. 1-15.

; MATTHIESSEN, C. An Introduction to Functional Grammar.

London, Melbourne: Edward Arnold, 2004.

HARVEY, D. A Condição Pós-Moderna. São Paulo: Editora Loyola, 1992.

HEIDEGGER, M. Ser e Tempo. Petrópolis, RJ: Editora Vozes, 1986.

HERCULANO, A. Lendas e Narrativas. Tomo II. Lisboa: Livraria Bertrand, 1975.

HERMANNS, H. Narrative Interviews. In: FLICK, U. et al. (Orgs). Handbuch Qualitative

Social Forschung. Muchen: Psycologie Verlags Union, 1991, p.182-185.

HOBSBAWN, E. A Era dos Extremos. São Paulo: Companhia das Letras, 1995. . Identity Politics and the Left. New Left Review, nº 217, 1996, p. 38-47.

IPEA. Brasil: o Estado de uma Nação. Edição resumida. Editores: Fernando Rezende e Paulo Tafner. Rio de Janeiro: IPEA, 2005.

JODELET, D. La Representación Social: Fenómenos, Concepto y Teoría. In: MOSCOVICI, S. (Org.). Psicologia Social. Barcelona, Paídos, 1985, p. 469-494.

Représentations Sociales: un Domain en Expansion. In: JODELET, D. Les

Représentations Sociales. Paris, Presses Universitaires de France, 1989a, p. 31-61. 
Folies et Représentations Sociales. Paris, Presses Universitaires de France, 1989b.

JORDÃO, C.M. Identidades e Letramentos em Discurso. In: SILVA, K.A.; ARAÚJO, J.C. (Orgs.). Letramentos, Discursos Midiáticos e Identidades: Novas Perspectivas. Campinas, SP: Pontes Editores, 2015, p. 7-23.

JOVCHELOVITHCH, S.; BAUER, M.W. Entrevista Narrativa. In: BAUER, M.W.; GASKELL, G. (Orgs.) Pesquisa Qualitativa com Texto, Imagem e Som: um Manual Prático. $11^{\mathrm{a}}$ ed. Petrópolis, RJ: Vozes, 2013, p. 90-113.

KAHLMEYER-MERTENS, R.S. Da interpretação Heideggeriana da Ética a Nicômaco: Filosofia Prática como Ontologia da Vida Cotidiana. In: Revista Ética e Filosofia Política, núm. XVI, vol. II, 2013, dez.

KUBOTA, R. Critical Multiculturalism and Second Language Education. In: NORTON, B. TOOHEY, K. (Eds.) Critical Pedagogies and Language Learning. Cambridge: Cambridge university Press, 2004, p. 30-52.

LEAL, G.F. Exclusão Social e Ruptura dos Laços Sociais: Análise Crítica do Debate Contemporâneo. Florianópolis: Editora da UFSC, 2011.

LEFFA, V. J. O Ensino do Inglês no Futuro: da Dicotomia para a Convergência. In: STEVEnS, C. M. T.; CUNHA, M. J. C. (Orgs.). Caminhos e Colheita: Ensino e Pesquisa na Área de Inglês no Brasil. Brasília: Editora UnB, 2003, p. 225-250.

LOIZOS, P. Vídeo, Filme e Fotografia como Documentos de Pesquisa. In: BAUER, M.W.; GASKELL, G. (Orgs.). Pesquisa Qualitativa com Texto, Imagem e Som: um Manual Prático. 11 a ed. Petrópolis, RJ: Vozes, 2013, p.137-155.

LOPES, J.R.B. Desenvolvimento e Migração: uma Abordagem Histórico-Estrutural. Novos Estudos CEBRAP 6, São Paulo, 1973.

LUCÀ, P.T. Religioni e Integrazione Degli Immigrati: Ricerche Americane e Italiane a Confronto. Bologna: D.U. Press, 2007.

van MAANEN, J. Tales of the Field: on Writing Ethnography. 2nd ed. The University of Chicago Press: Chicago and London, 2011.

MARICATO, E. Exclusão Social e Reforma Urbana. Revista Proposta. Rio de Janeiro, n. 62, 1994, p. 51-56, set.

MARSHALL, T.H. Cidadania, Classe Social e Status. Rio de Janeiro: Zahar, 1967. 
MARTIN, J.R.; WHITE, P. The Language of Evaluation: Appraisal in English. London: Palgrave Macmillan, 2005.

MARTINS, J.S. Fronteira: a Degradação do Outro nos Confins do Humano, São Paulo: Hucitec, 1997.

MARX, K. O Capital: Crítica da Economia Política. São Paulo: Difel, 1985.

MATEUS, E. O Que é Ensinar/Aprender Língua(gem)? In: SILVA, K.A.; ARAGÃO, R.C.

(Orgs.). Conversas com Formadores de Professores de Línguas: Avanços e Desafios. Campinas, SP: Pontes Editores, 2013, p. 93-111.

MARTIN, J. R. Beyond Exchange: Appraisal Systems in English. In: HUNSTON, S.; THOMPSON, G. (Eds.) Evaluation in Text: Authorial Stance and the Construction of Discourse. Oxford: Oxford University Press, 2000, p. 142-175.

;; WHITE, P. R. R. The Language of Evaluation: Appraisal in English.

Houndmills and New York: Palgrave, 2005.

MAHER, T. M. A Educação do Entorno para a Interculturalidade e o Plurilinguismo. In: KLEIMAN, A.B.; CAVAlCANTI, M. (Orgs.) Volume Comemorativo do Jubileu de Prata do DLA/UNICAMP. Campinas, SP: Mercado das Letras, 2007b, p. 255-270.

MEY, J.L. Whose Language? A Study in Linguistics Pragmatics. Amsterdam: John Benjamins Publishing Company, 1985.

. As Vozes da Sociedade: Seminários de Pragmática. Trad. Ana C. Aguiar e Viviane Veras. Campinas, SP: Mercado das Letras, 2001.

MILES, M.B. Qualitative Data as an Attractive Nuisance: the Problem of Analysis. Administrative Science Quarterly, 24, 1979, p. 590-601.

MILESI, R. Por uma Nova Lei de Migrações: a Perspectiva dos Direitos Humanos. In: Cadernos de Debates Refúgio, Migrações e Cidadania, v. 2, n. 2. Brasília: Instituto Migrações e Direitos Humanos, 2007, p. 77-96.

MORAIS, F.B.C. A Representação das Mulheres na Política Brasileira: Um Estudo Sob a Perspectiva Sistêmico-Funcional. Cadernos de Linguagem e Sociedade, v. 13, nº 2, Brasília: Thesaurus Editora, 2012, p. 61-83.

MOSCOVICI, S. A Representação Social da Psicanálise. Rio de Janeiro: Zahar, 1978. . Notes Towards a Description of Social Representations. European Journal of Social Psychology, 18, 1988, p. 211-250. 
Dés Représentations Collectives Aux Représentations Sociales. In:

JODELET, D. Les Représentations Sociales. Paris, Presses Universitaires de France, 1989a, p. $62-86$.

NASCIMENTO, E.P. (Org.). A Difícil Constituição da Exclusão Social no Brasil. Temas CODEPLAN (Políticas Públicas: Exclusão Social), Brasília, 1998, p. 31-57.

NICOLAIDES, C.; SILVA, K.A.; TILIO, R.; ROCHA, C.H. (Orgs.). Políticas e Políticas Lingüísticas. Campinas, SP: Pontes Editores (ALAB), 2013.

OEA. Migración Internacional en las Américas: Segundo Informe del Sistema Continuo de Reportes sobre Migración Internacional en las Américas (SICREMI), 2012.

OIM. Perfil Migratório do Brasil 2009. Genebra: OIM, 2010.

PAPA, S.M.B.I. Realismo Crítico e Análise Crítica do Discurso: Reflexões para o(a) Educador(a) de Línguas em Processo Emancipatório e de Transformação Social. Cadernos de Linguagem e Sociedade, v. 10 n 1, Brasília: Thesaurus, 2009.

PATARRA, N.L. (Coord). Emigração e Imigração Internacionais no Brasil Contemporâneo. São Paulo: FNUAP, 1995. . Políticas e Gestão das Migrações Internacionais: Entre Direitos Humanos

e Soberania Nacional. In: TURRA, C. M.; CUNHA, J. M. P. (Org.) População e Desenvolvimento em Debate: Contribuições da Associação Brasileira de Estudos Populacionais. Belo Horizonte: ABEP, 2012, p.85-92.

PENNYCOOK, A. Critical Applied Linguistics: a Critical Introduction. London: Lawrence Erlbaum Associates, 2001.

PENNYCOOK, A. Os Limites da Linguística. In: RAJAGOPALAN, K.; SILVA, F.L. (Orgs.) A Linguística que Nos Faz Falhar: Investigação Crítica. São Paulo: Parábola Editorial, 2004. . Uma Linguística Aplicada Trangressiva. In: MOITA-LOPES, L.P. (Org.) Por uma Linguística Aplicada Indisciplinar. São Paulo: Parábola Editorial, 2008, p. 67-83. PIOVESAN, F. A Universalidade e a Indivisibilidade dos Direitos Humanos: Desafios e Perspectivas. In: Direitos Humanos na Sociedade Cosmopolita. São Paulo: Renovar, 2004. PUHL, P. R. Ideologia, Vingança e Loucura: a Hermenêutica Revive em Hamlet. Lisboa: BOCC, 2003. 
RADHAY, R. A. Discurso e Poder na Política de Imigração Brasileira. 334 f. Tese (Doutorado). Instituto de Letras, Universidade de Brasília, Brasília, 2006.

RAJAGOPALAN, K. O Conceito de Identidade em Linguística: é Chegada a Hora para uma Reconsideração Radical? In: SIGNORINI, I. (Org.). Língua(gem) e Identidade: Elementos para uma Discussão no Campo Aplicado. Campinas, SP: Mercado das Letras, 1998.

. Por uma Linguística Crítica: Linguagem, Identidade e a Questão Ética. São Paulo: Parábola, 2003.

; SILVA, F.L. (Orgs.). A Linguística que Nos Faz Falhar: Investigação Crítica. São Paulo: Parábola Editorial, 2004.

; FERREIRA, D.M.M. (Orgs.) Políticas em Linguagem: Perspectivas Identitárias. São Paulo: Mackenzie, 2006.

.; Pós-Modernidade e a Política de Identidade. In: RAJAGOPALAN, K.; FERREIRA, D.M.M. (Orgs.). Políticas em Linguagem: Perspectivas Identitárias. São Paulo: Mackenzie, 2006, p. 61-80.

. Nova Pragmática: Fases e Feições de um Fazer. São Paulo: Parábola

Editorial, 2010.

RANCIÈRE, J. O Desentendimento. Trad. Angela Leite Lopes. São Paulo: Editora 34, 1996.

RAMALHO, V. Análise de Discurso e Realismo Crítico: Princípios para uma Abordagem

Crítica Explanatória do Discurso. Anais da XII Conferência Anual da Associação Internacional para o Realismo Crítico, 2009, p. 1-19.

.; RESENDE, V.M. Análise de Discurso (para a) Crítica: o Texto como

Material de Pesquisa. Campinas, SP: Pontes Editores, 2011.

ROBINSON, K. All Our Futures: Creativity, Culture and Education. In: The National Advisory Committee on Creative and Cultural Education. London: NACCCE Report, May, 1999.

ROCHA, C.H. Reflexões e Propostas Sobre Língua Estrangeira no Ensino Fundamental I: Plurilinguismo, Multiletramentos e Transculturalidade. Campinas, SP: Pontes Editores, 2012. ROJO, R.H.R. Fazer Linguística Aplicada em Perspectiva Sócio-Histórica: Privação Sofrida e Leveza de Pensamento. In: MOITA-LOPES, L.P. (Org.). Por uma Linguística Aplicada Indisciplinar. São Paulo: Parábola Editorial, 2006. 
. Letramentos Múltiplos: Escola e Inclusão Social. São Paulo: Parábola, 2009a.

SÁ, R.L. Imigração Hispanoamericana em São Paulo, (Des)construção Identitária e Inclusão dos (In)visíveis: um Olhar da Linguística Sistêmico-Funcional. In: III Workshop Systemic Across Languages (SAL). Brasília: Universidade de Brasília, 2014.

SATO, D.T.B. A Inclusão da Pessoa com Síndrome de Down: Identidades Docentes, Discursos e Letramentos. 149 f. Dissertação (Mestrado). Instituto de Letras, Universidade de Brasília, Brasília, 2008.

SAUSSURE, F. Curso de Linguística Geral. São Paulo: Cultrix, 2003.

SAYER, A. Características-chave do Realismo Crítico na Prática: um Breve Resumo. Estudos de Sociologia. Revista do Programa de Pós-Graduação em Sociologia da UFPE, 6. 2, 2000, p. 7-32.

SCHWARTZMAN, S.; REIS, E. Pobreza e Exclusão. In: GACITÚA-MARIÓ, E.; WOOLKOCK, M. (Org.). Exclusão Social e Mobilidade no Brasil. Brasília: Ipea, 2005, p. 147-180.

SEMPRINI, A. Multiculturalismo. Bauru, SP: EDUSC, 1999.

SILVA, T. T. (Org.) Identidade e Diferença: a Perspectiva dos Estudos Culturais. $15^{\text {a }}$ edição. Petrópolis, RJ: Vozes, 2014.

SILVA, D.N. A Questão da Identidade em Perspectiva Pragmática. Revista Brasileira de Lingüística Aplicada, v. 8, nº 1, 2008.

; FERREIRA, D.M.M.; ALENCAR, C.N. (Orgs.). Nova Pragmática: Modos de Fazer. São Paulo: Cortez Editora, 2014.

SILVA, S.A. Costurando Sonhos: Etnografia de um Grupo de Imigrantes Bolivianos que Trabalham no Ramo da Costura em São Paulo. 291 f. Dissertação (Mestrado). PPGIAL Universidade de São Paulo, São Paulo, 1995.

. Faces da Latinidade Hispano-Americano em São Paulo. Campinas, SP: Núcleo de Estudos de População/Unicamp, 2008, 73 p.

. Bolivianos em São Paulo: Dinâmica Cultural e Processos Identitários. In:

BAENINGER, R. (Org.). Imigração Boliviana no Brasil. Campinas: NEPO-Universidade Estadual de Campinas, 2012. 
SILVA, F.C.O. A Construção Social de Identidades Étnico-Raciais: uma Análise Discursiva do Racismo no Brasil. 141 f. Tese (Doutorado). Instituto de Letras, Universidade de Brasília, Brasília, 2009.

SILVA, K.A.; ARAÚJO, J.C. (Orgs.) Letramentos, Discursos Midiáticos e Identidades: Novas Perspectivas. Campinas, SP: Pontes Editores, 2015.

SIMMEL G. Digression Sur L'Étranger. In: GRAFMEYER Y.; JOSEPH I. L'École de Chicago, Naissance de L'Écologie Urbaine. Paris: Ed. Du Champ Urbain, 1979, p. 53-77.

SOUSA SANTOS, B. Renovar a Teoria Crítica e Reinventar a Emancipação Social. Trad. Mouzar Benedito. São Paulo: Boitempo, 2007.

SOUTO-MAIOR, R.C. O Que é Ensinar/Aprender Língua(gem)? In: SILVA, K.A.; ARAGÃO, R.C. (Orgs.). Conversas com Formadores de Professores de Línguas: Avanços e Desafios. Campinas, SP: Pontes Editores, 2013, p. 251-264.

SPAAN, E. Labour Circulation and Socioeconomic Transformation: the Case of East Java, Indonesia. Netherlands Interdisciplinary Demographic Institute Report, $\mathrm{n}^{\mathrm{o}}$ 56, The Hague, 1999.

SPIVAK, G.C. Can the Subaltern Speak? In: NELSON, C; GROSSBERG, L. (Eds.). Marxism and the Interpretation of Culture. Urbana: University of Illinois Press, 1999, p. 271-313.

SPOSATI, A. Exclusão Social Abaixo da Linha do Equador. In: VÉRAS, M.P.B. (Ed.) Por uma Sociologia da Exclusão Social: o Debate com Serge Paugam. São Paulo: Educ, 1999, p. 126-138.

TEIXEIRA, P.E. et al. Migrações: Implicações Passadas, Presentes e Futuras. São Paulo: Cultura Acadêmica, 2012.

THOMPSON, J.B. Ideologia e Cultura Moderna: Teoria Social Crítica na Era dos Meios de Comunicação de Massa. Petrópolis, RJ: Vozes, 1995.

Ideologia e Cultura Moderna: Teoria Social Crítica na Era dos Meios de Comunicação de Massa. Trad. (Coord.) Pedrinho A. Guareschi. Petrópolis, RJ: Vozes, 2002a. TOSTA, T.L.D. Memórias das Ruas, Memórias da Exclusão. In: BURSZTYN, M. (Org.). No Meio da Rua: Nômades, Excluídos e Viradores. Rio de Janeiro: Garamond, 2003, p. 201-229. 
TOURAINE, A. Igualdade e Diversidade: o Sujeito Democrático. Bauru, SP: EDUSC, 1998. Poderemos Viver Juntos? Iguais e Diferentes. Petrópolis, RJ: Vozes, 1999.

WATCHTOWER Bible \& Tract Society of New York, Inc. Meu Livro de Histórias Bíblicas. 3 ed. Brooklyn, Nova Iorque, E.U.A, 2012.

. Estudo Perspicaz das Escrituras, vol. 3. Brooklyn, Nova Iorque,

E.U.A, 1992.

. Testemunhas de Jeová: Proclamadores do Reino de Deus. Brooklyn,

Nova Iorque, E.U.A, 1993.

. 'Dê Testemunho Cabal' Sobre o Reino de Deus. Brooklyn, Nova

Iorque, E.U.A, 1992.

WERNECK, C. Ninguém Mais Vai Ser Bonzinho na Sociedade Inclusiva. Rio de Janeiro: WMA, 1997.

WOODWARD, K. Identidade e Diferença: uma Introdução Teórica e Conceitual. In: SILVA, T. T. (Org.). Identidade e Diferença: a Perspectiva dos Estudos Culturais. Petrópolis: Vozes, 2000, p.7-72. 


\section{APÊNDICE A}

\section{Fragmentos de atividade no grupo focal}

2) Al pensar en el tema de la identidad, cree usted que la comunidad acá contribuye:

4 ¿a que los extranjeros preserven la suya asimilando y cuadrando con lo mejor de la brasileña?

si ellos respetan,

5 ¿a que el uso del Português sea una herramienta útil para el manejo de la doble identidad? Si porque hotalonente nescesario para poder conucivir
entu hodos.

5) ¿Qué imágenes de Bolívia y/o Brasil le vinieron a la mente al participar en la investigación?
An
ion
decin.
me hace
anali quiom realmente s imiguante
or er 5

4) ¿Cuáles son los impactos positivos y negativos del proceso de inmigración a Brasil?

3. Bullyng, sem sentido a quando bu infarmodos a moior parte dos braslisior acrita e ayuda

6) ¿Cómo usted decide acerca de la lengua que debes/quieres usar?

No momanto, na ocapião.

¿En que situaciones lo decide? ¿Por qué lo decide así?

Duperidende do prerea, a do arsunto.

Penque tern que verr a mansina mair facil de expresear.

3) ¿Qué tipo de barreras te has topado o cree que haya en la acomodación de los inmigrantes acá?

- el mal kábito de los ex trangrer: borrachera, fal fa de Hyérueno. 
167

APÊNDICE B

Fragmento de nota de campo

'Se fue y mi mama ne praviuio "i-

* Varric (lavablorganizebe Ganhar confiante por comida/cama.

* Meincentivaron a vir a Brasil (prira pagou passagem). 6 Chegrereina copa 94 Csalamio p/ facan ruito baixo

sakin minimo

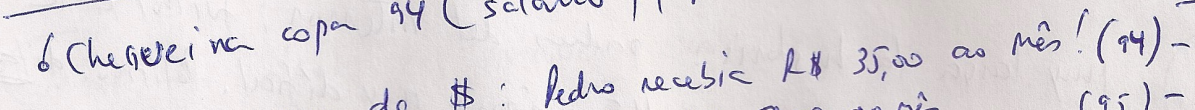

corece converse de $\$$ camline $1 \$ \$ 5,00$ av ins Juar R\& 3100,00 ao in
$(95)-$

$(2010)-$

$(2000)-$

pacion \$1-3,00/peca;

$$
\text { parters } \$ 0,05 \text { (15 anos atrón) }
$$
* Vides - sibe Tunsmo en Solivis -o esperave reacho
lurion bućolio deles au que vinem

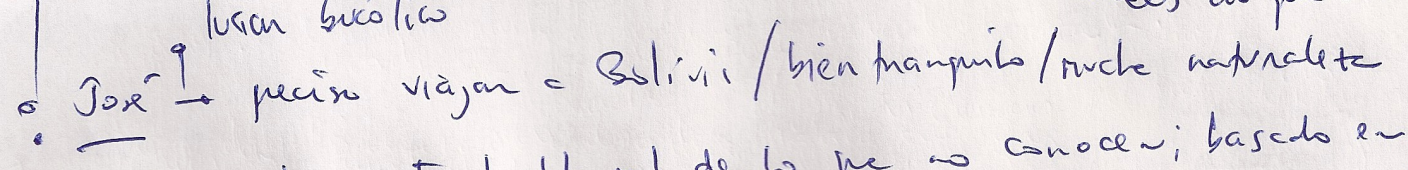

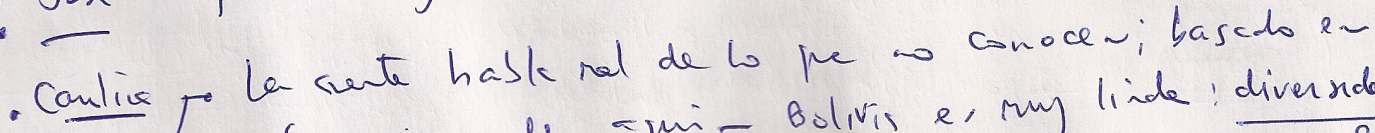

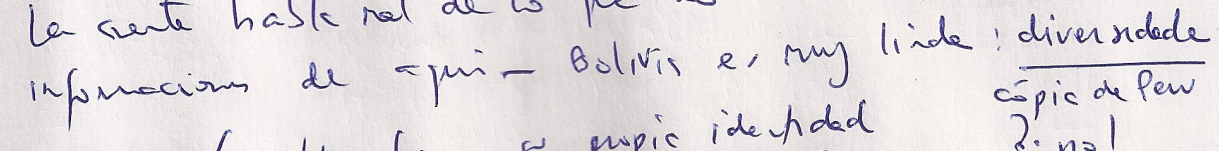

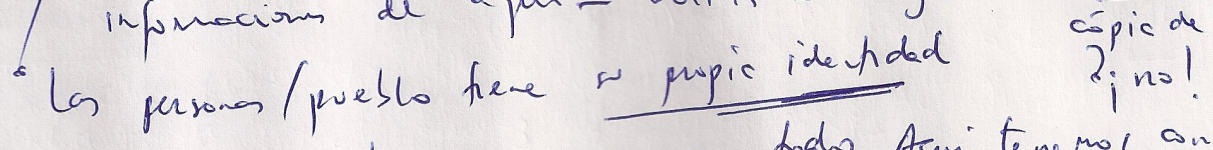

- Juar - Los popior bulivianos no conocen fodo. Agui teme mos cankéto con otwos de ts lusanes (se note for el acente)

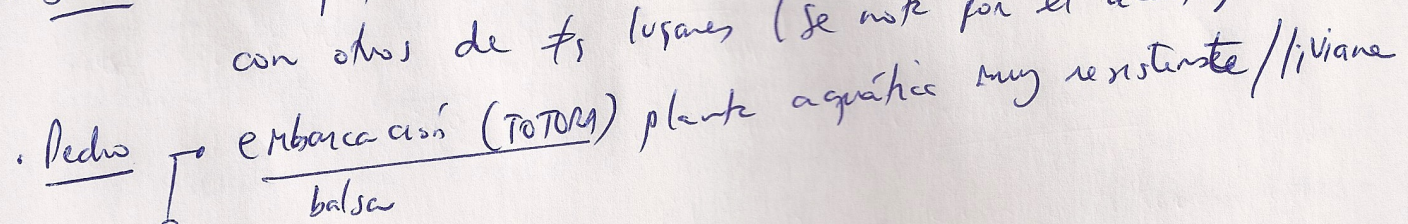




\section{APÊNDICE C}

\section{Fragmentos de narrativas escritas}

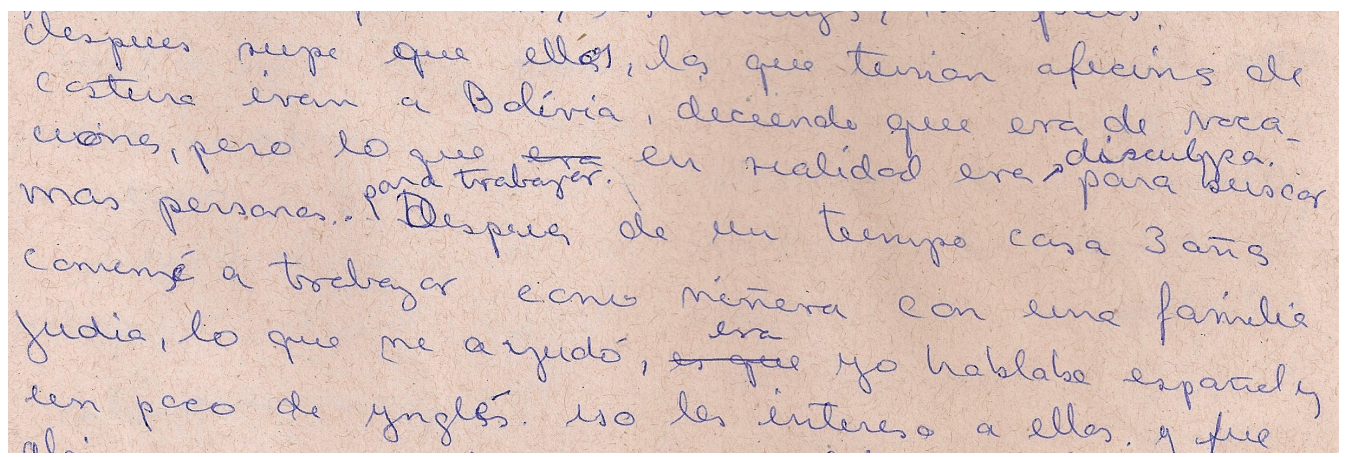

\footnotetext{
1

Tor mivito. Tempo, permonec trancado em casa com oneus pais. pós nöo gostoromor de nos errvobur con causas ecternas entas so saia de cosea para ir a escola, e finais de semona, para fazer muito átivo. me tornar muito quieto, porem de pensamento
}

Uiviaudo mas omenos unto años uno se acostumbra., I

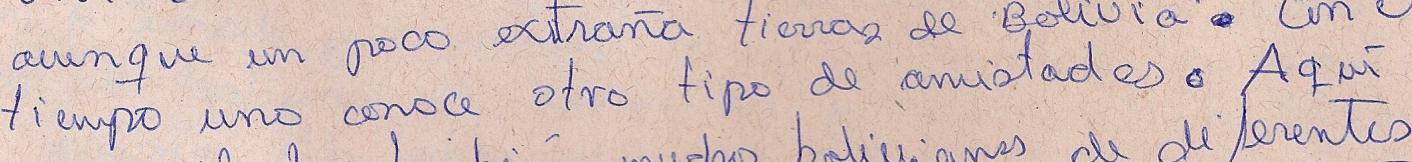
en prasil hay tambión mucho bolivians de de/erentes ol departamento do Bolivi a cmozco Paceños, ountenes, Patrimos. Suceños Belalanos pasi de todo. de los departá mentos/de Balinia. / casi ofo en fa Paz no Conoá tanto asé

- Como un vrovia a maior pante do tompo na reas a un acaber pegan duo algur-

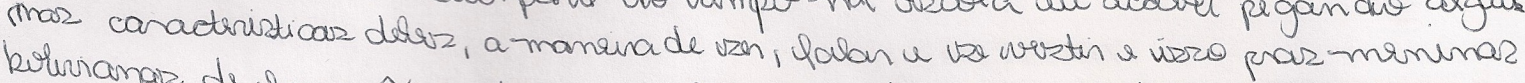
tive que de fora, noü gestarra me adrarnam patriomha e metida. Maz un manrina da voldan uma maneina viha um alqum ambunte a me moldei a pela mantinazcola, até porque 82 novos bolvianos que untranaum Rofriam muito

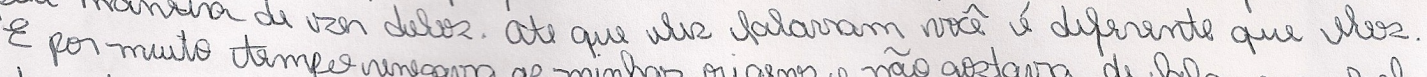
dez costumer.

Sentimos prejuicio, pere no dar mucha importancia preferimos estar en canto, estamos concientes de que somos extranferos. 


\section{APÊNDICE D}

Exemplos de narrativas visuais
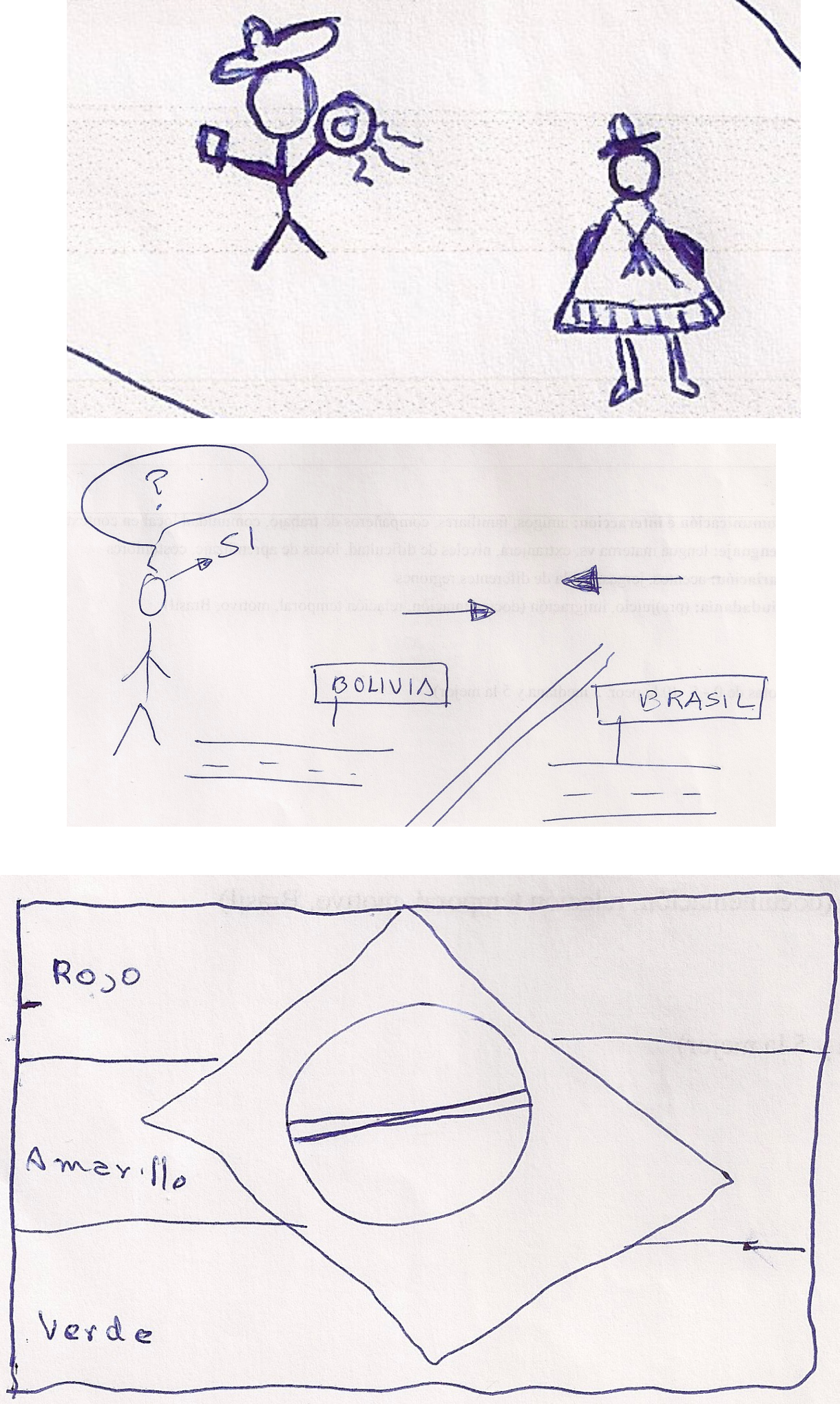


\section{APÊNDICE E}

Fotos e fonte dos videoclipes usados pelo autor

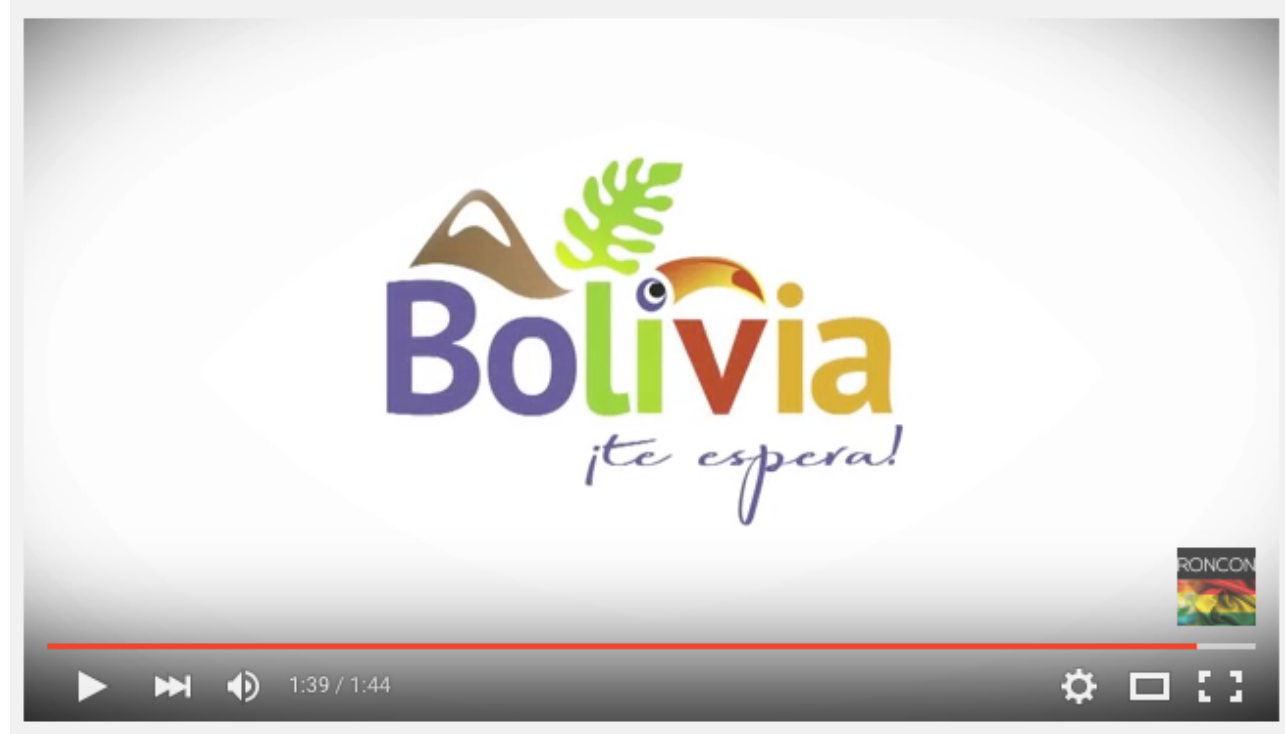

Fonte: http://www.youtube.com/watch?v=3oDyrqlRBs0

\section{El emigrante}

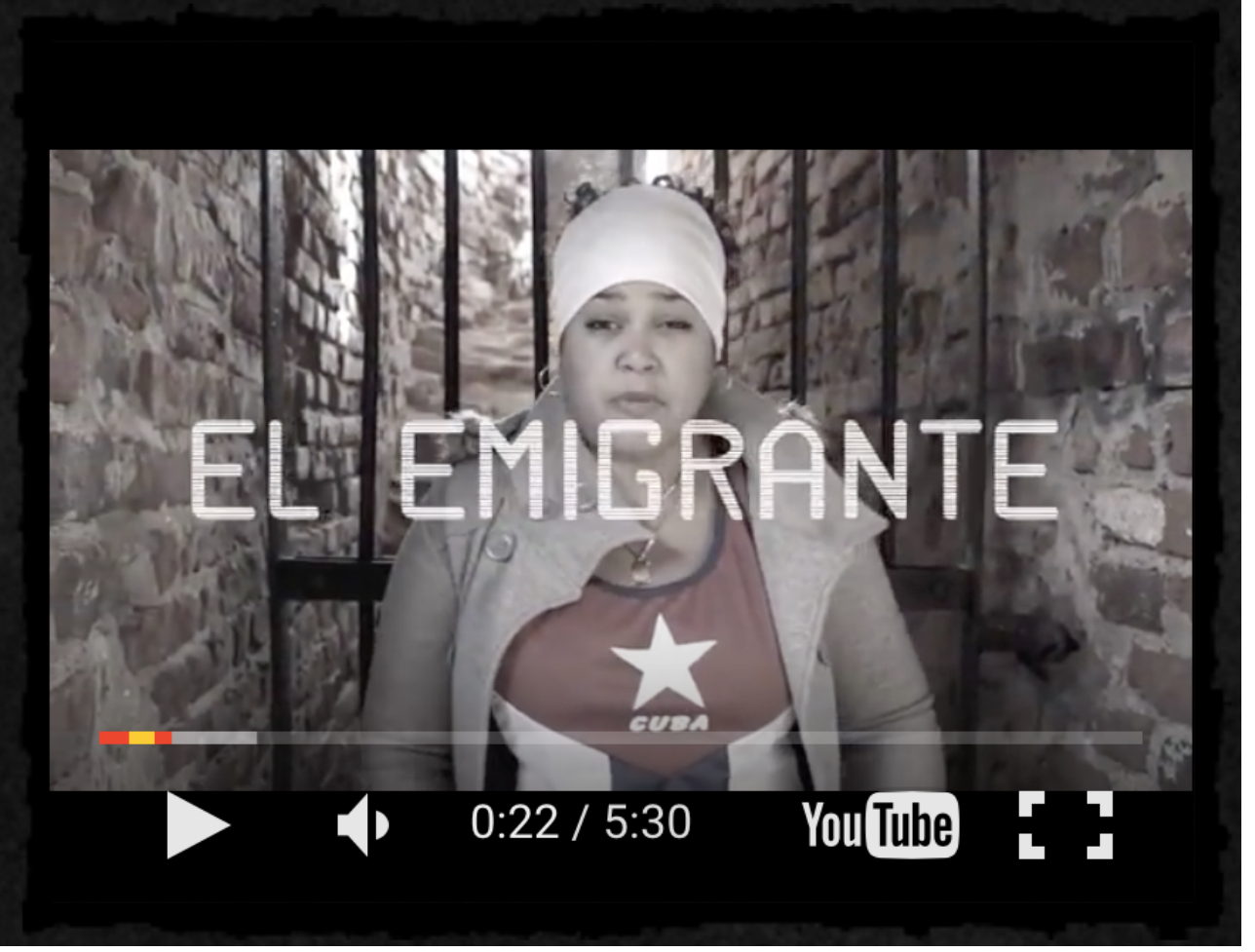

Fonte: http://www.normiqueen.com/\#!videos/c9qb 


\section{APÊNDICE F}

Imagens da Bolívia

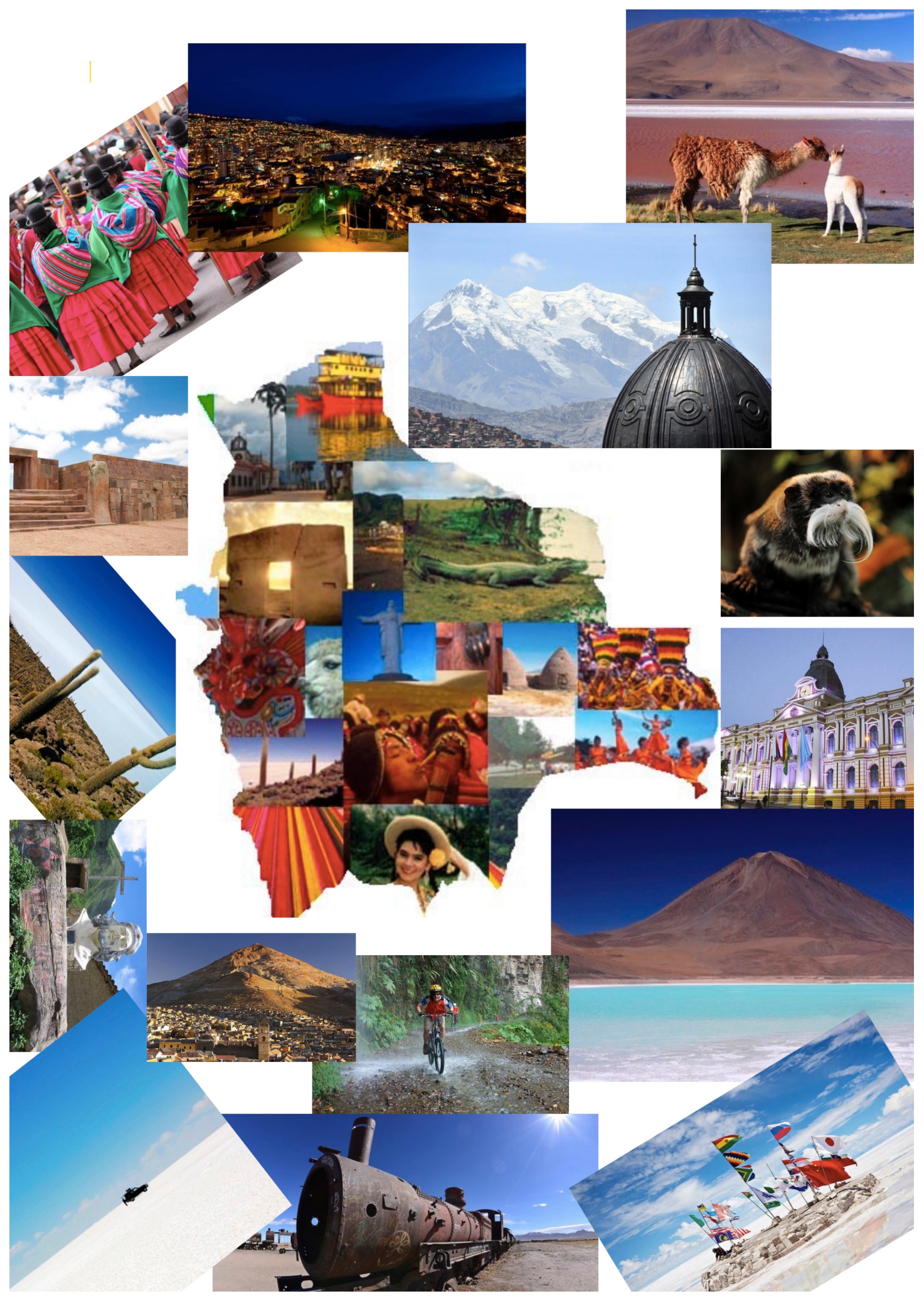

Fonte: http://viajeaqui.abril.com.br/paises/bolivia/fotos 
Teus, ó Jeová, são a grandeza, e a potência, e a beleza, e a excelência, e a dignidade; pois [teu] é tudo nos céus e na terra. Teu é o reino, ó Jeová, que te ergues como cabeça sobre todos. As riquezas e a glória existem por tua causa e tu dominas sobre tudo; e na tua mão há poder e potência, e na tua mão há [a capacidade] para engrandecer e para dar força a todos. E agora, ó nosso Deus, te agradecemos e louvamos o teu belo nome. 